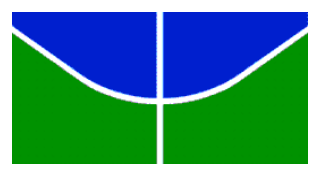

Universidade de Brasília - UnB

Instituto de Letras - IL

Departamento de Linguística, Português e Línguas Clássicas - LIP

Programa de Pós-Graduação em Linguística - PPGL

\title{
PRÁTICAS DISCURSIVAS DISCIPLINADORAS VOLTADAS PARA ADOLESCENTES: UMA PERSPECTIVA CRÍTICA
}

Ana Cláudia Camargo Carvalho 
Ana Cláudia Camargo Carvalho

\section{PRÁTICAS DISCURSIVAS DISCIPLINADORAS VOLTADAS PARA ADOLESCENTES: UMA PERSPECTIVA CRÍTICA}

Tese apresentada ao Programa de Pós-Graduação em Linguística do Departamento de Linguística, Português e Línguas Clássicas do Instituto de Letras da Universidade de Brasília, como parte dos requisitos para a obtenção do grau de Doutora em Linguística. Área de concentração: Linguagem e Sociedade.

Orientadora: Prof. ${ }^{a}$ Dra. Denize Elena Garcia da Silva 
Ficha catalográfica elaborada automaticamente, com os dados fornecidos pelo(a) autor(a)

$\mathrm{Cp}$

Carvalho, Ana Cláudia Camargo

Práticas Discursivas Disciplinadoras Voltadas Para Adolescentes: uma perspectiva crítica / Ana Cláudia Camargo Carvalho; orientador Denize Elena Garcia da Silva. -- Brasília, 2016. $262 \mathrm{p}$.

Tese (Doutorado - Doutorado em Linguística) -Universidade de Brasília, 2016.

1. Discurso disciplinador. 2. Adolescente, socioeducando. 3. Linguística Sistêmico-Funcional. 4. Análise de Discurso Crítica. 5. Documentos Oficiais e regimentos. I. Silva, Denize Elena Garcia da , orient. II. Título. 


\section{Ana Cláudia Camargo Carvalho}

\section{PRÁTICAS DISCURSIVAS DISCIPLINADORAS VOLTADAS PARA ADOLESCENTES: UMA PERSPECTIVA CRITICA}

Tese apresentada ao Programa de Pós-Graduaçẫo em Linguística do Departamento de Linguística, Portuguếs e Linguas Clássicas do Instituto de Letras da Universidade de Brasilia, como parte dos requisitos para a obtençăo do grau de Doutora em Linguística. Área de concentraçâo: Linguagem e Sociedade.

Defendida e aprovada em.

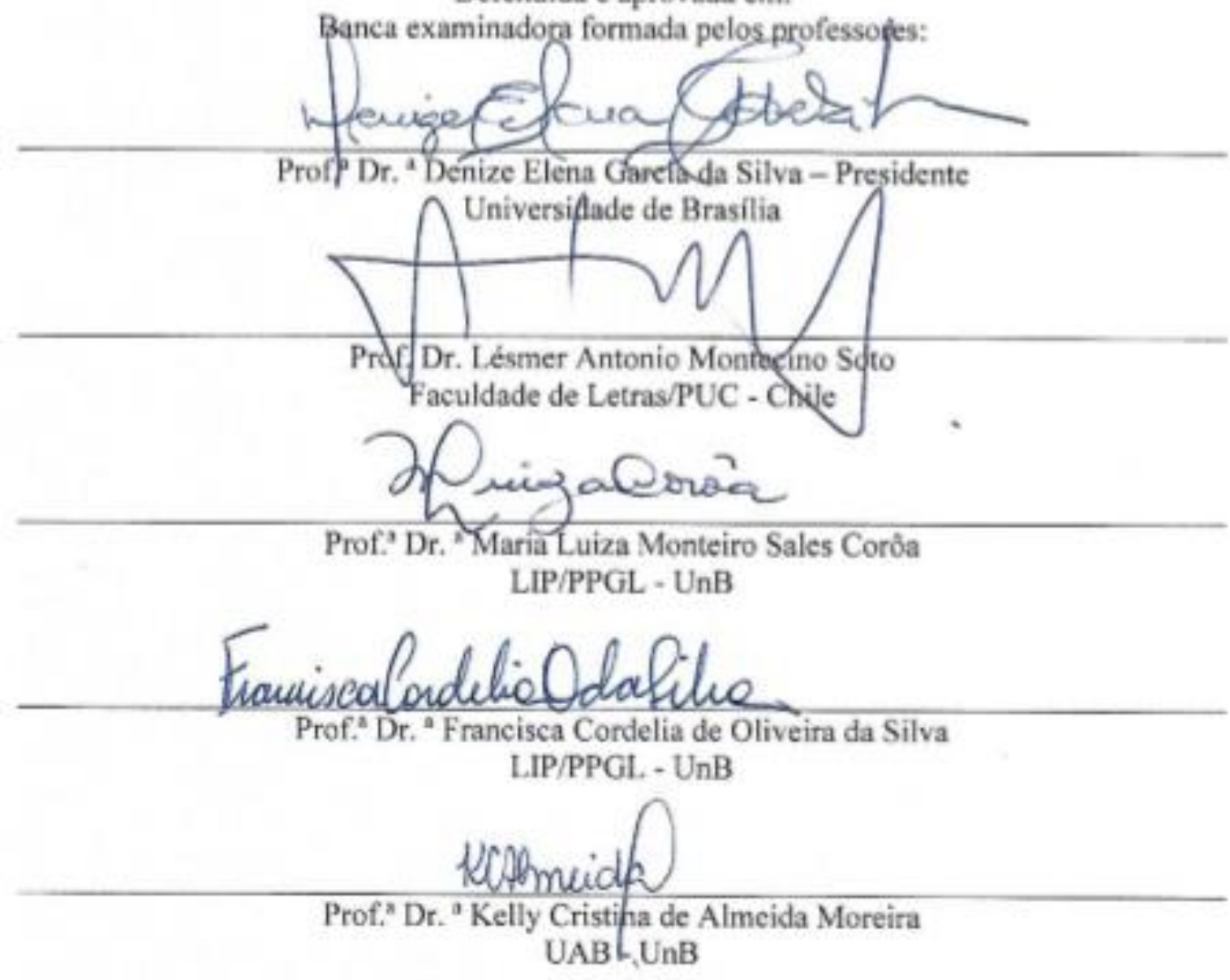


Dedico esta tese àquele(a)s que parecem ser invisíveis e inexistentes aos olhos da sociedade. 


\section{AGRADECIMENTOS}

Agradeço, primeiramente, a Deus, pela vida e por ter-me permitido chegar até aqui.

Agradeço à minha orientadora, professora doutora Denize Elena Garcia da Silva por ter acreditado na minha ideia, pelas incursões metafóricas em encontros tão aprazíveis de orientação, por ter-me brindado com importantes contribuições para esta tese e pelo carinho e paciência em todos os momentos.

Agradeço aos meus pais, Wilson e Ana Maria, pelo amor incondicional, pelo exemplo de ética, solidariedade, força, por todos os conselhos e incentivos e pelo esforço em me ajudarem nesse período.

Agradeço ao Luciano, meu porto seguro, pela paciência, pela compreensão, pela cumplicidade e pelo amor. Por me dar coragem para prosseguir e seguir sempre em frente, sem desistir dos meus sonhos.

Agradeço aos meus filhos, Iago e Rodrigo, razões do meu viver, por entenderem a minha ausência em tantos momentos durante esses quatro anos e por me darem, todos os dias, amor, tranquilidade e carinho. Vocês trazem a luz em minha vida.

Agradeço aos meus irmãos, Henrique e Júnior, que me ajudaram com palavras de incentivo e pelas grandes contribuições e sugestões a esse trabalho.

Agradeço às minhas tias Elisabeth e Graça, pelo incentivo, amizade e carinho.

Agradeço aos meus sogros, Luís Carlos e Graça, pela ajuda e compreensão.

Agradeço à Sandra, Carina, Ângela, Simone, Risalva, Alley, Fernando, Miguel Ângelo pela amizade, pela ajuda e por momentos tão especiais em que estivemos juntos, bem como por compartilharem o conhecimento.

Agradeço à professora doutora Maria Luiza Corôa, pela sensibilidade, por ter-me direcionado a desenvolver o conceito de discursos disciplinadores e por ter aceitado integrar a banca.

Agradeço à professora doutora Kelly Cristina Moreira, pela amizade, pelo entusiasmo, pelas contribuições neste trabalho e por ter aceitado integrar a banca.

Agradeço à professora doutora Cordélia da Silva pela generosidade e pelas contribuições neste trabalho e por ter aceitado integrar a banca.

Agradeço ao professor doutor Lésmer Montecino por ter aceitado integrar a banca de doutorado e pelas relevantes contribuições neste trabalho.

Agradeço à professora doutora Juliana Freitas Dias fazer parte da banca de doutorado. 
Agradeço à professora doutora Edna Muniz da Silva pela amizade e pelos ensinamentos durante as aulas de LSF.

Agradeço à professora doutora Leila Bárbara por todos os ensinamentos, pela alegria e por todas as animadas conversas.

Agradeço à Raquel, à Ângela, ao Vítor e à Renata que sempre se dispuseram a me ajudar com relação a assuntos de secretaria.

Agradeço ao estimado Cel Pinheiro, por suas falas filosóficas, tão significativas, e pelo constante incentivo.

Agradeço ao Cel Bandeira, ao Cel Darko, ao Cel Nunes, ao Gen Denilson Correia pela ajuda e compreensão.

Agradeço à equipe da UISM que sempre me recebeu com muita simpatia e atenção.

Agradeço, imensamente, aos adolescentes colaboradores do CMB e da UISM que participaram deste estudo.

Enfim, agradeço a todos que, de alguma forma, contribuíram para a concretização dessa tese.

\section{GRATIDÃO!}




\section{RESUMO}

Esta tese configura uma pesquisa de natureza qualitativa (descritiva e interpretativa), uma vez que envolve dados documentais e dados de natureza etnográfica, com o propósito de colaborar para uma mudança social específica em favor de grupos marginalizados. Trata-se de uma contribuição almejada em termos de reintegração e reeducação social de adolescentes em situação de reclusão, que sairão das Unidades de Internação e irão viver e conviver em sociedade. Os dados documentais foram selecionados a partir de uma cadeia de gêneros discursivos de ordem de discurso legal, a qual abrange direitos e deveres dos adolescentes. Com o objetivo de discutir, à luz da Análise de Discurso Crítica e da Linguística SistêmicoFuncional, representações linguístico-discursivas voltadas para adolescentes, buscou-se realizar um estudo comparativo com base em Regimentos Internos (RI) de instituições públicas, bem como seus desdobramentos balizados em leis. Trata-se do Regimento dos Colégios Militares, do Regimento das Unidades de Internação, do Estatuto da Criança e do Adolescente de 1990 e a da Constituição Federal do Brasil de 1988. Os dados empíricos de natureza etnográfica foram gerados junto a adolescentes do Colégio Militar de Brasília (CMB) e da Unidade de Internação de Santa Maria (UISM). Os procedimentos metodológicos escolhidos foram a observação participante, as entrevistas semiestruturadas e as notas de campo. As amostras, posteriormente selecionadas para o corpus, foram colhidas entre os anos de 2014 a 2016 junto a adolescentes, de 12 a 18 anos. Entre os colaboradores da pesquisa, estavam, de um lado, estudantes do CMB e, de outro lado, adolescentes em situação de reclusão da UISM, ambas as instituições no DF. O arcabouço teórico que baliza a pesquisa abarca as duas dimensões da linguagem: o discurso (exterioridade), nos moldes de Fairclough (2001; 2003; 2010), quem propõe uma concepção de linguagem como prática social, assim como a estrutura do sistema linguístico (interioridade), na linha da teoria Linguística Sistêmico-Funcional, proposta por Halliday (1994) e ampliada em Halliday e Matthiessen (2004). Complementa esse embasamento teórico-analítico o estudo sobre o Sistema de Avaliatividade, desenvolvido por Martin (2000) e Martin e White (2005). Na análise documental, são utilizadas duas ferramentas do programa computacional WordSmith Tools. Entre os resultados alcançados, destaca-se o hiato existente entre o RICM e o RIUI do DF. Os resultados do estudo significam uma contribuição em favor de adolescentes que (sobre)vivem, ainda, em situação de vulnerabilidade social.

Palavras-chave: Análise de Discurso Crítica. Linguística Sistêmico-Funcional. Regimentos. Adolescentes. Socioeducandos. 


\begin{abstract}
This research constitutes a qualitative research (descriptive and interpretative), once it involves documentary and ethnographic data. It aims to contribute to a specific social change in favor of underprivileged groups. Socially speaking, it means a desired contribution to reintegrate and reeducate adolescents who will leave detention centers and return to society. The documentary data was selected from a wide range of genres comprising legal discourse orders, which cover the rights and duties of adolescents. In order to discuss, in the light of Critical Discourse Analysis and Systemic Functional Linguistics, linguistic and discursive representations aimed at teenagers, a comparative study was carried out based upon the Internal Regulation of public institutions and other deployments in the law, namely the Rules of the Military Schools, the Code of Conduct used in Detention Centers, the 1990 Child and Adolescent Statute and the 1988 Federal Constitution of Brazil. Empirical data from ethnographic nature was collected through interviews at the Military School in Brasília and a Youth Detention Center located in Santa Maria-DF. Additionally, participant observation, semi-structured interviews and field notes constituted the methodological procedures. The samples for the corpus were collected between the years 2014-2016 with adolescents whose age range from 12 to 18 years old. Among the collaborators of the research, on one side, the students from the Military School, and, on the other side, teens in detention situation in Santa Maria's Youth Detention Center. The theoretical framework guiding the thesis covers the two dimensions of the language: discourse (externality), as of Fairclough $(2001 ; 2003 ; 2010)$, who conceives language as a social practice, as well as the structure of the linguistic system (interiority), in alignment with the Systemic Functional Linguistics theory proposed by Halliday (1994), expanded in Halliday and Matthiessen (2004). The theoretical and analytical foundations were developed according to the Appraisal System developed by Martin (2000) and Martin and White (2005). To aid the documentary analysis, two tools from the WordSmith Tools program were utilized. Amongst the results achieved, we can highlight the gap between the Internal Rules of the Military Schools and the Code of Conduct used in Youth Detention Centers - both located in the Federal District. The results mean a contribution in favor of underprivileged adolescents who still undergo social vulnerability situations.
\end{abstract}

Keywords: Critical Discourse Analysis. Systemic Functional Linguistics. Regulations. Adolescents. Adolescents in situation of detention. 


\section{LISTA DE FIGURAS}

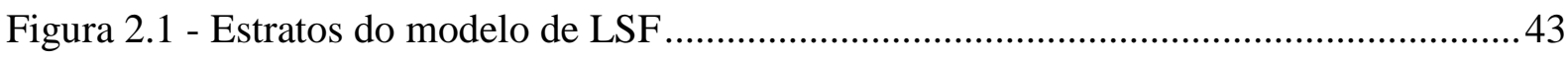

Figura 2.2 - Mandala da Gramática da Experiência ............................................................. 49

Figura 2.3 - Diagrama da Relação de Modalidade e Polaridade .............................................58

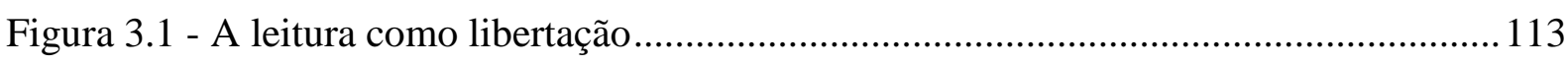

Figura 4.1 - Asilo de Menores Abandonados ................................................................... 119

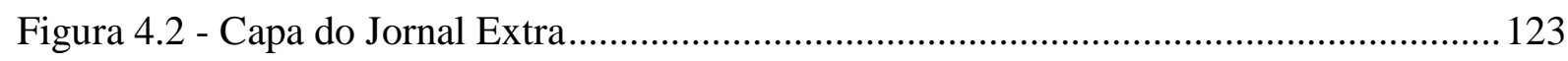

Figura 4.3 - Encadeamento do objeto do discurso nos regimentos ..................................... 128

Figura 4.4 - Cadeia de Gêneros Discursivos do Regimento Interno dos Colégios Militares . 147

Figura 4.5 - Cadeia de Gêneros Discursivos do Regimento Interno das Unidades de Internação

Figura 4.6 - Representação de adolescentes como objeto do discurso do Código de Menores de 1927 ao ECA. 193

Figura 4.7 - Representação de adolescentes como objeto de discurso no RIUI e no RICM..194 


\section{LISTA DE QUADROS}

Quadro 1.1 - Demonstrativo de efetivo de alunos/ano no CMB ............................................ 33

Quadro 1.2 - Demonstrativo de efetivo de alunos/ano na escola da UISM............................. 34

Quadro 2.1 - Recontextualização da LSF na ADC............................................................ 72

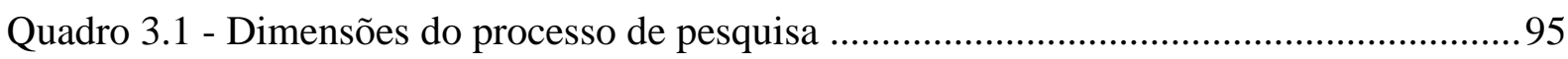

Quadro 3.2 - Perguntas básicas para os adolescentes da UISM e do CMB .......................... 102

Quadro 3.3 - Perfil dos adolescentes da Unidade de Internação de Santa Maria (UISM) e do

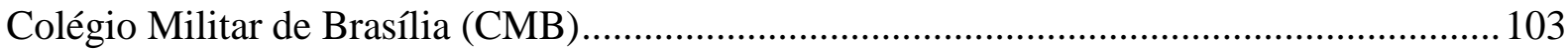

Quadro 4.1 - Representação do termo adolescente na CF, no ECA, no RIUI e no RICM.....126

Quadro 4.2 - Estrutura do Regimento Interno dos Colégios Militares .................................. 141

Quadro 4.3 - Estrutura do Regimento Interno das Unidades de Internação ........................... 144

Quadro 4.4 - Quadro comparativo entre o RICM e o RIUI.................................................. 169

Quadro 4.5 - Diferenças e semelhanças dos instrumentos disciplinares indicados por Foucault nos Colégios Militares e nas Unidades de Internação ........................................................ 185

Quadro 4.6 - Representação dos Adolescentes em Documentos Oficiais .............................. 192

Quadro 5.1 - Intertextualidade entre o RIUI e do ECA....................................................236 


\section{LISTA DE GRÁFICOS}

Gráfico 4.1 - Representação lexical de "adolescente” na CF ............................................... 130

Gráfico 4.2 - Representação lexical de "adolescente” no ECA .............................................. 133

Gráfico 4.3 - Representação lexical de "adolescente” no RIUI ............................................ 135

Gráfico 4.4 - Representação lexical de "adolescente” no RICM …......................................137

Gráfico 4.5 - Processos mais frequentes no RIUI ............................................................... 154

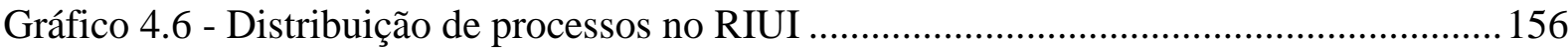

Gráfico 4.7 - Processo material Concreto e Abstrato no RIUI ...............................................158

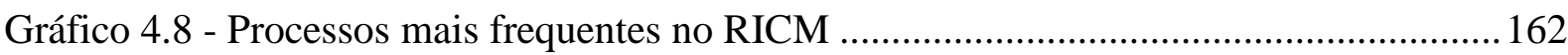

Gráfico 4.9 - Distribuição de processos no RICM ................................................................. 164

Gráfico 4.10 - Processo material Concreto e Abstrato no RICM ............................................. 166

Gráfico 5.1 - Demonstrativo de níveis de razão e consequência...........................................205

Gráfico 5.2 - Demonstrativo da relação linguística de razão e consequência em relato de socioeducando 


\section{LISTA DE FOTOGRAFIAS}

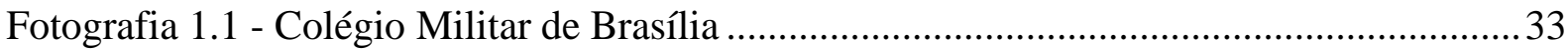

Fotografia 1.2 - Unidade de Internação de Santa Maria.............................................................. 36

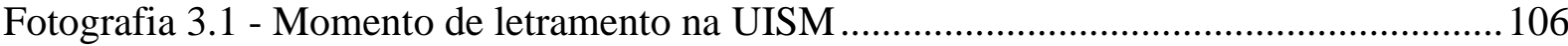




\section{LISTA DE ESQUEMA}

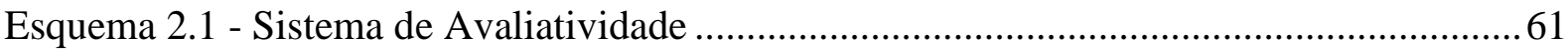

Esquema 2.2 - Correspondência dos Subsistemas de Atitude ..............................................63

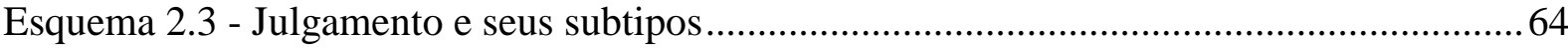

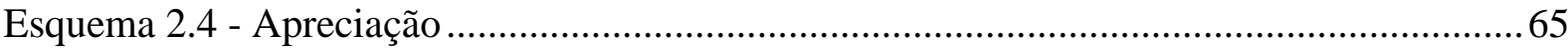

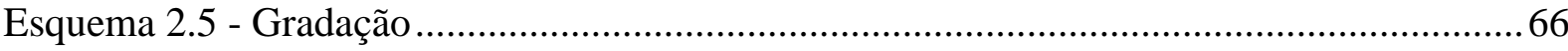

Esquema 2.6 - Correlação dos três grandes eixos de Foucault e os três aspectos de significado

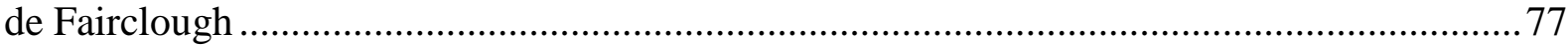

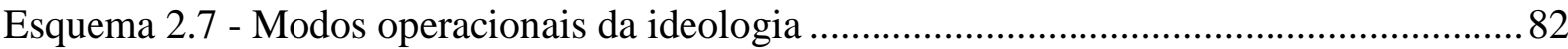




\section{LISTA DE TABELAS}

Tabela 4.1 - Dimensões e densidade lexical (statistics) da Constituição Federal ................... 130

Tabela 4.2 - Dimensões e densidade lexical (statistics) do ECA ......................................... 132

Tabela 4.3 - Dimensões e densidade lexical (statistics) do RIUI ........................................ 135

Tabela 4.4 - Dimensões e densidade lexical (statistics) do RICM ...................................... 137

Tabela 4.5 - Processos mais frequentes no Regimento Interno das Unidades de Internação. 153

Tabela 4.6 - Processos mais frequentes no Regimento Interno dos Colégios Militares......... 161 


\section{LISTA DE SIGLAS}

ADC Análise de Discurso Crítica

CA Corpo de Alunos

CC Código Civil

CF $\quad$ Constituição Federal de 1988

CLT Consolidação das Leis Trabalhistas

CM Colégio Militar

CMB Colégio Militar de Brasília

DE Divisão de Ensino

DEP Departamento de Ensino e Pesquisa

DEPA Diretoria de Educação Preparatória e Assistencial

DF Distrito Federal

ECA Estatuto da Criança e do Adolescente

EPG Estrutura Potencial de Gênero

GEAD Grupo de Estudos em Álcool e outras Drogas

GESAU Grupo de Atuação Especial de Defesa da Saúde

GESEG Grupo Especial de Segurança

LDB Lei de Diretrizes e Bases da Educação

LSF Linguística Sistêmico-Funcional

NAEB Normas de Avaliação da Educação Básica

NPGE Normas de Planejamento e Gestão Escolar

PAAE Programa para Avanço das Aprendizagens Escolares

REDLAD Rede Latino-Americana de Estudos do Discurso da Pobreza Extrema

RI Regimento Interno

RICM Regimento Interno dos Colégios Militares

RIUI Regimento Interno das Unidades de Internação

SAM Serviço de Assistência ao Menor

SCMB Sistema Colégio Militar de Brasília

SINASE Sistema Nacional de Atendimento Socioeducativo

UAI Unidade de Atendimento Inicial

UI Unidade de Internação

UIP Unidade de Internação de Planaltina

UISM Unidade de Internação de Santa Maria 
UISM Unidade de Internação de Santa Maria

UISS Unidade de Internação de São Sebastião

UnB Universidade de Brasília

UNIRE Unidade de Internação do Recanto das Emas 


$\begin{array}{ll}\text { CONVENÇÕES DE TRANSCRIÇÃO } & \text { Descrição } \\ \text { DOS DADOS ORAIS Símbolo } & \\ : . & \text { alongamento de vogal } \\ :: & \text { alongamento maior de vogal } \\ \text { / } & \text { parada brusca } \\ (()) & \text { comentários do analista } \\ \text { “" } & \text { discurso direto } \\ \ldots & \text { pausa } \\ \text { MAIÚSCULA } & \text { ênfase na voz } \\ \text { Itálico } & \text { expressões próprias da fala } \\ , & \text { (vírgula) entonação média } \\ ! & \text { entonação ascendente de exclamação } \\ ? & \text { entonação ascendente de interrogação } \\ . & \text { entonação descendente } \\ \text { /..../ } & \text { transcrição parcial ou parte suprimida } \\ (X X X) & \text { fala incompreensível }\end{array}$




\section{SUMÁRIO}

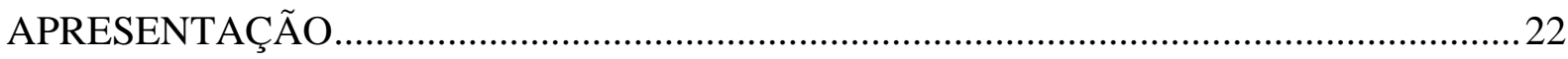

Capítulo 1 - ADOLESCENTES E CONTEXTOS INSTITUCIONAIS …..............................28

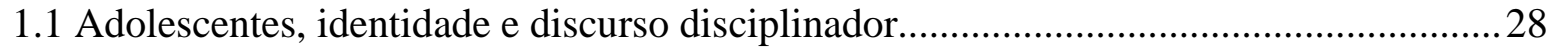

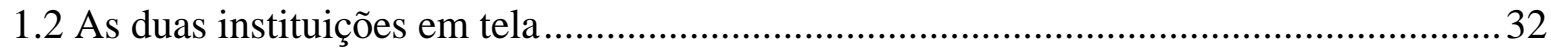

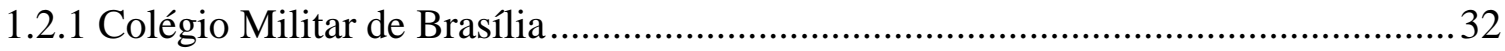

1.2.2 Unidade de Internação de Santa Maria ................................................................... 34

1.3 Adolescentes e o sistema educacional: uma lacuna a ser preenchida ............................36

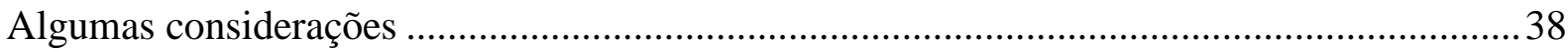

Capítulo 2 - DA INTERIORIDADE À EXTERIORIDADE DA LINGUAGEM SOB UMA

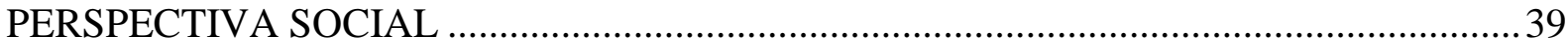

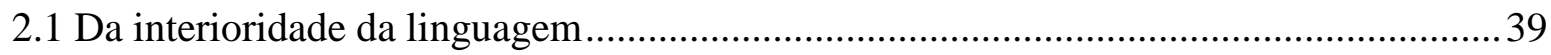

2.1.1 Organização da linguagem por meio de estratos.................................................... 42

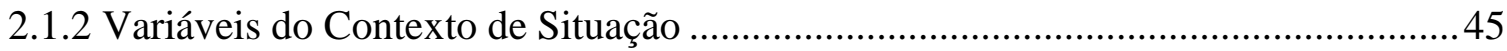

2.1.3 As Metafunções e suas realizações léxico-gramaticais ........................................... 46

2.2 Metafunção ideacional: a oração como representação................................................... 47

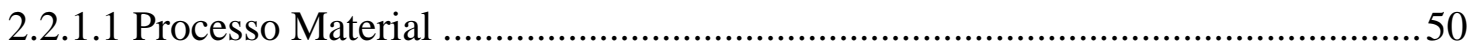

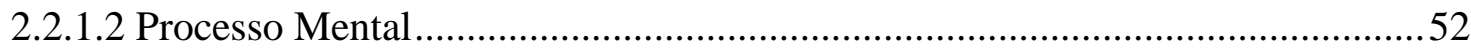

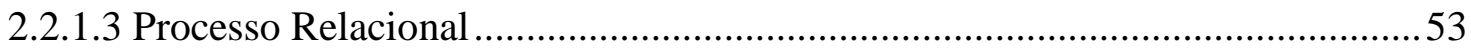

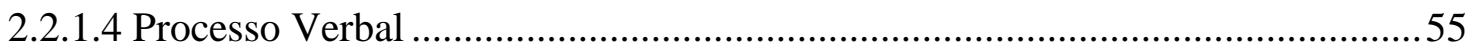

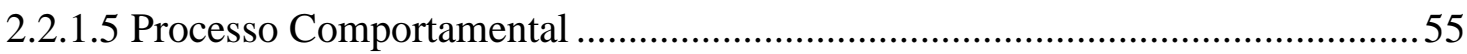

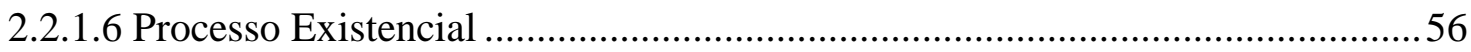

2.3 Metafunção Interpessoal - Oração como troca.................................................................56

2.4 Metafunção Textual - Oração como Mensagem .........................................................59

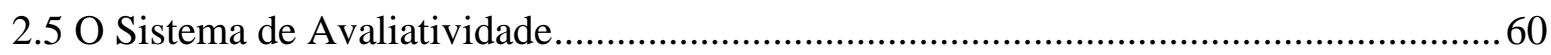

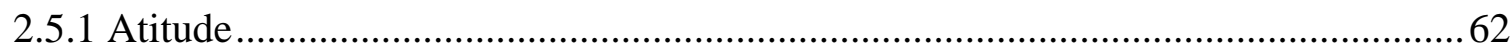

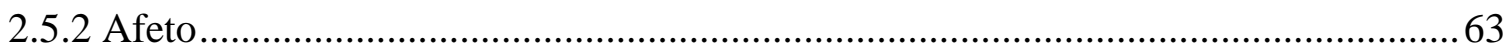

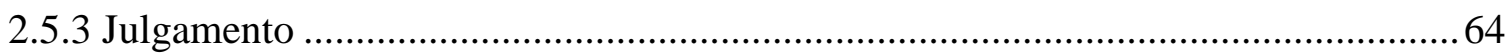

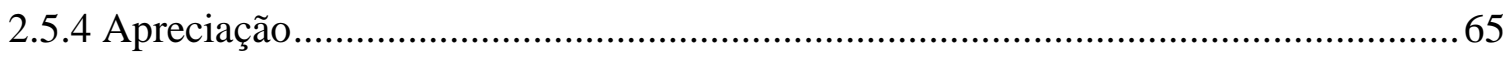

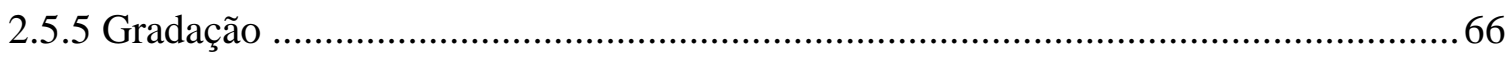

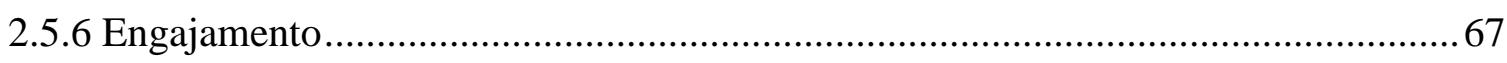

2.6 Da exterioridade da linguagem: o discurso como prática social.................................67

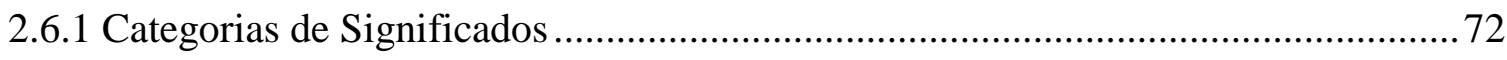

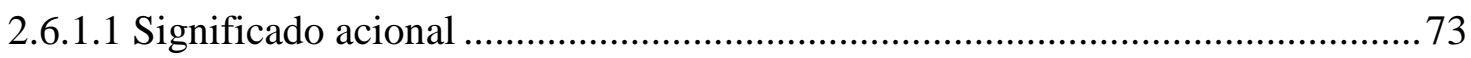

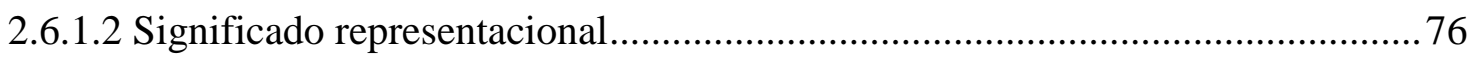


2.6.1.3 Significado identificacional

2.6.2 Discursos disciplinadores: o poder disciplinador como prática social.....................78

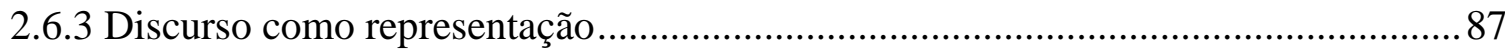

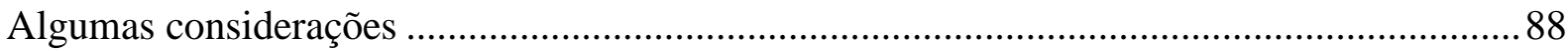

Capítulo 3 - DELINEAMENTO DO PERCURSO METODOLÓGICO .................................90

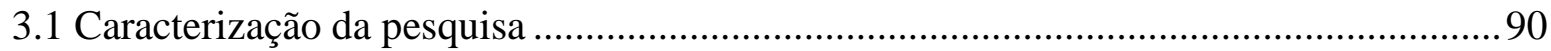

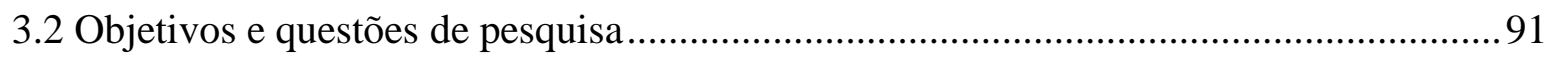

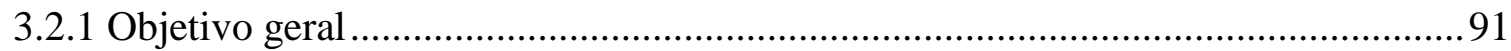

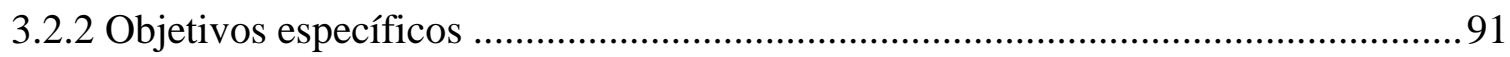

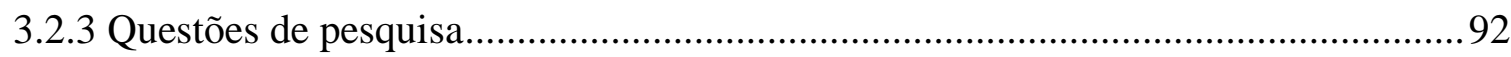

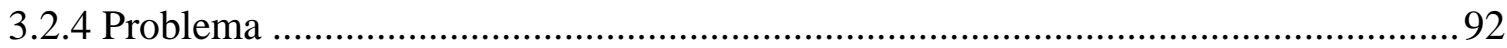

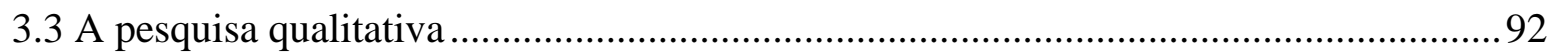

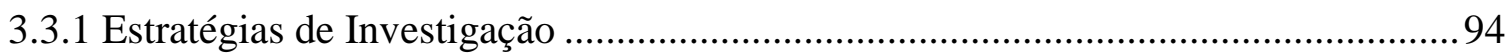

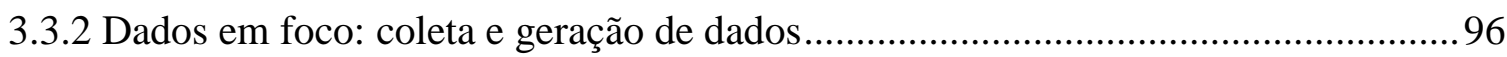

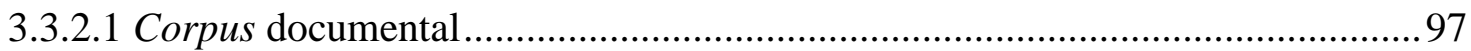

3.3.2.2 Geração de dados de natureza etnográfica ..................................................... 98

3.3.2.3 Entrada no campo e questões de ética .......................................................... 98

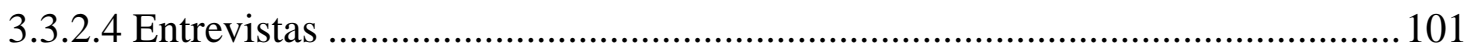

Perguntas básicas para os adolescentes da UISM e do CMB: ............................... 102

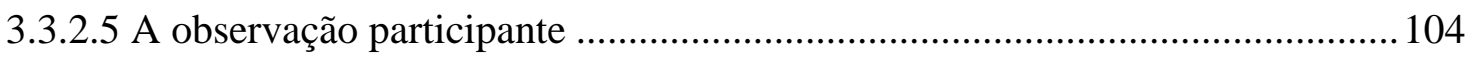

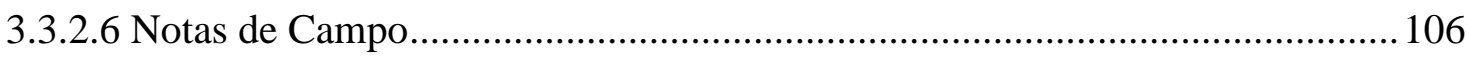

3.4 Unidade de Internação de Santa Maria e Colégio Militar de Brasília .......................... 107

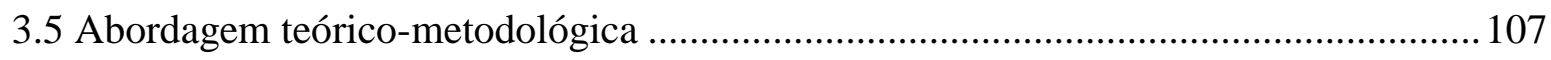

3.5.1 Abordagem teórico-metodológica da ADC ….................................................... 108

3.5.2 Abordagem teórico-metodológica da LSF ...................................................... 110

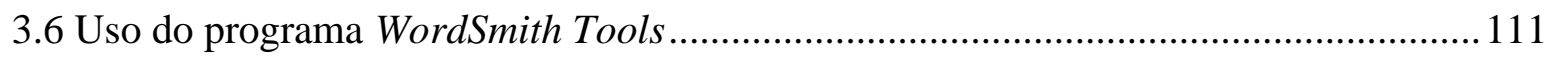

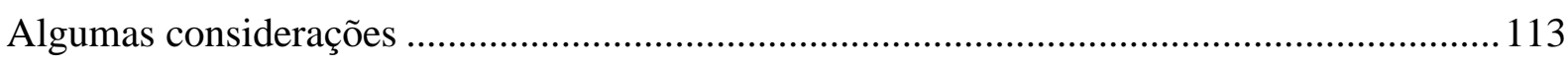

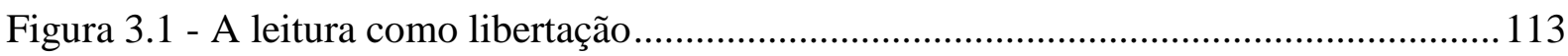

Capítulo 4 - REPRESENTAÇÃO DOS ADOLESCENTES COMO OBJETO DO

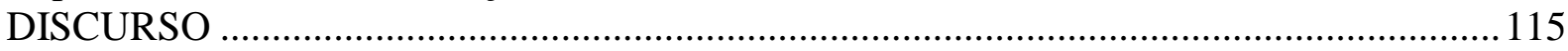

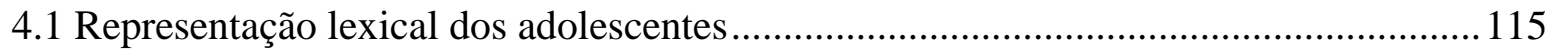

4.2 Documentos oficiais: nas trilhas do WordSmith Tools ............................................... 129

4.2.1 Representação lexical de adolescentes na Constituição Federal de 1988 ............... 129

4.2.2 Representação lexical de adolescentes no Estatuto da Criança e do Adolescente. 131

4.2.3 Representação lexical de adolescentes no Regimento Interno das Unidades de Internação 
4.2.4 Representação lexical de adolescentes no Regimento Interno dos Colégios Militares

4.3 O Regimento como gênero textual e ação social .......................................................... 140

4.3.1 As cadeias de gêneros discursivos normativos em ação ....................................... 145

4.4 Regimentos sob a lupa do WordSmith Tools .................................................................. 152

4.4.1 Componentes da transitividade dentro do Regimento Interno das Unidades de Internação

4.4.1.1 A representação das ações e o sistema de transitividade no Regimento Interno das Unidades de Internação

4.4.2 Componentes verbais mais frequentes no Regimento Interno dos Colégios Militares 161

4.4.2.1 A representação das ações e o sistema de transitividade no Regimento Interno dos Colégios Militares 163

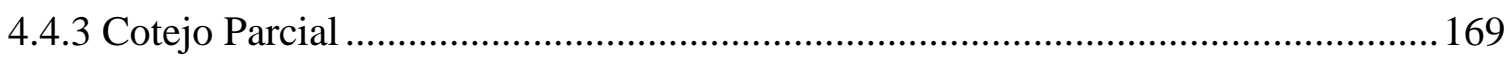

4.5 Análise documental de acordo com a LSF e a ADC .............................................. 171

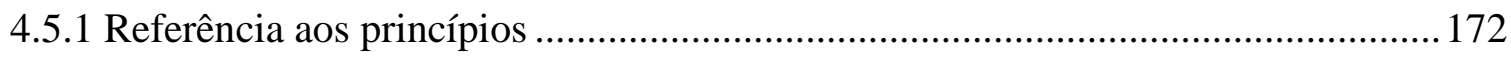

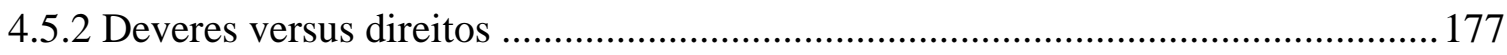

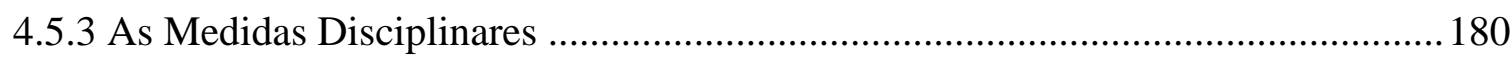

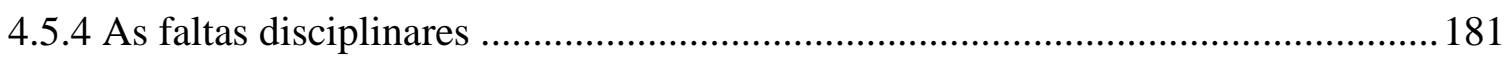

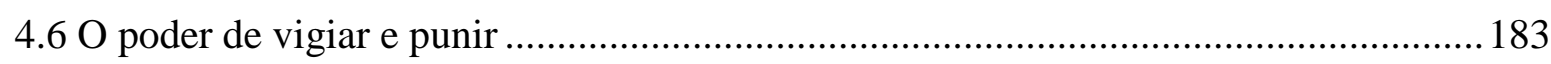

4.7 Modos operacionais propostos por Thompson nos Regimentos Internos dos CM e das

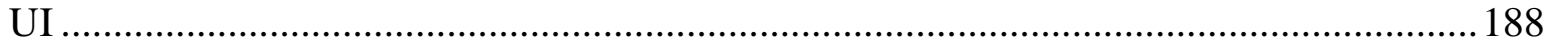

Considerações com base em resultados parciais ................................................................. 192

Capítulo 5 - A VOZ DOS ADOLESCENTES: UM DUETO EM CONTRASTE .................198

5.1 Relações linguístico-discursivas nos relatos de adolescentes .....................................198

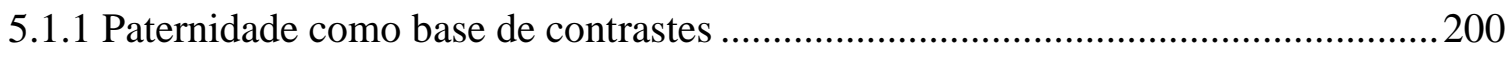

5.1.2 Razão e consequência: o vício e as drogas em conectividade com os delitos .......204

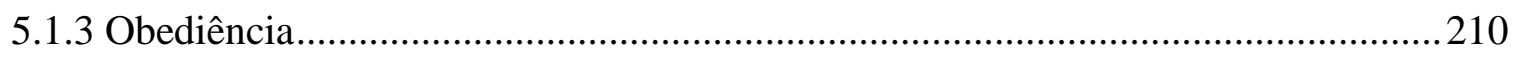

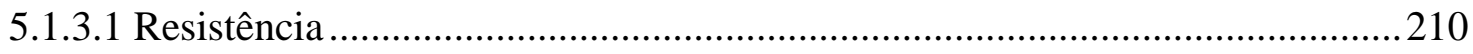

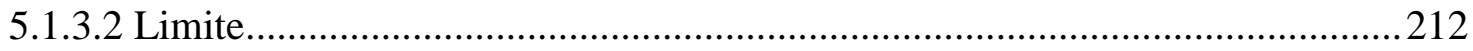

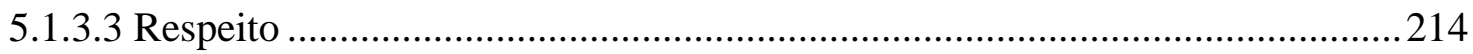

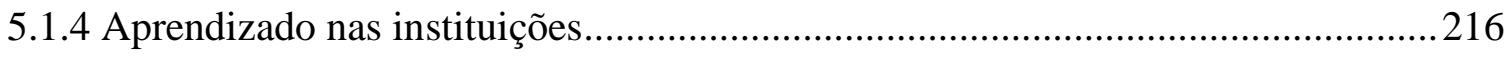

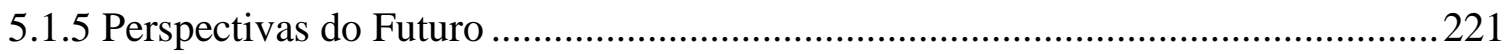

5.2 A redução da maioridade penal na voz avaliativa dos adolescentes...........................227

$5.3 \mathrm{O}$ cruzamento de textos legais versus vozes divergentes.........................................235

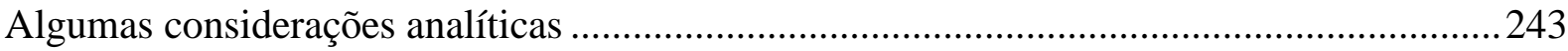

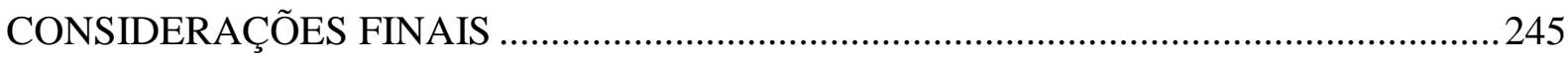


REFERÊNCIAS . 


\section{APRESENTAÇÃO}

Esta tese se dedica a um duplo caminho, no qual se encontram vozes oriundas de contextos de situação distintos. Por um lado, gritos abafados de adolescentes, em situação de reclusão da Unidade de Internação de Santa Maria (UISM), que se encontram à margem da sociedade e, por outro, vozes de alunos do Colégio Militar de Brasília que ecoam condutas de comportamento e disciplina. O objetivo central do estudo ora apresentado é discutir, à luz da Análise de Discurso Crítica e da Linguística Sistêmico-Funcional, as representações linguístico-discursivas voltadas para adolescentes registradas nos Regimentos Internos de suas respectivas instituições. O propósito subjacente é identificar como se efetuam as representações linguístico-discursivas de adolescentes em Documentos Oficiais, bem como apontar em que momentos os discursos dos adolescentes se alinham e/ou se afastam.

Esta pesquisa está integrada à Rede Latino-Americana de Estudos do Discurso da Pobreza Extrema - REDLAD, por meio do Grupo Brasileiro de Estudos de Discurso, Pobreza e Identidade (UnB - CNPq/DGP). Trata-se de um desdobramento de um projeto mais amplo "Meu nome, minha identidade": das práticas discursivas aos eventos de letramento voltados para adolescentes e pessoas idosas, coordenado pela professora Dra. Denize Elena Garcia da Silva, líder da REDLAD - Brasil.

Busco discutir, à luz da Análise de Discurso Crítica (ADC) e da Linguística Sistêmico-Funcional (LSF), as representações linguístico-discursivas voltadas para adolescentes do Colégio Militar de Brasília (CMB) e adolescentes da Unidade de Internação de Santa Maria (UISM) em Documentos Oficiais.

Além do objetivo geral, há cinco objetivos específicos norteadores deste estudo, quais sejam:

- mostrar como se efetuam as representações linguístico-discursivas de adolescentes em Documentos Oficiais;

- apontar quais as semelhanças e as diferenças entre os regimentos do CMB e da UISM;

- contrastar, à luz do pensamento foucaulteano, os instrumentos disciplinares previstos nos Colégios Militares e nas Unidades de Internação;

- elencar as categorias linguístico-discursivas mais recorrentes nos relatos dos adolescentes; 
- discernir em que momento os discursos dos adolescentes pertinentes aos dois contextos da capital federal se alinham e onde se afastam em relação à redução da maioridade penal.

Os objetivos, acima, encontram-se relacionados às seguintes questões de pesquisa que serão retomadas nos próximos capítulos.

1) Como os adolescentes são representados e identificados nos Documentos Oficiais?

2) Quais são as semelhanças e as diferenças entre os regimentos do CMB e da UISM?

3) Quais as semelhanças e diferenças dos instrumentos disciplinares indicados por Foucault nas instituições CMB e UISM?

4) Quais categorias linguístico-discursivas são encontradas nos relatos dos adolescentes?

5) Em que momento os discursos dos adolescentes, no que se refere ao tema da redução da maioridade penal, alinham-se e quando se afastam?

Com o propósito de aproximar respostas às questões acima elencadas, busco conjugar a ADC à LSF, utilizando uma dimensão teórico-metodológica de natureza crítica, voltada para o discurso como prática social. Essas duas propostas teórico-metodológicas foram escolhidas, porque, em ambas, pode-se trabalhar o lado social da linguagem (discurso) sem que se perca a dimensão da interioridade (gramática).

Nessa dupla ancoragem, os aspectos discursivos, que fazem da língua um contrato social, são enfocados a partir dos estudos de Fairclough (2003) sobre os significados da linguagem em sua exterioridade, com o suporte da Linguística Sistêmico-Funcional (LSF), no que tange a questões linguísticas, de acordo com a asserção de Halliday (1994) e ampliada em Halliday e Matthiessen (2004), cuja proposta teórico-metodológica é utilizada como ferramenta na análise da dimensão interna da linguagem, a partir do estudo da relação entre os processos de transitividade (Gramática da Experiência) e outros elementos e aspectos da vida social. Os procedimentos metodológicos escolhidos envolvem entrevistas semiestruturadas, observação participante e notas de campo.

No contexto brasileiro, apesar dos paradoxos existentes, o adolescente é (ou deveria ser) reconhecido como sujeito de direitos e deveres, considerado como pessoa em desenvolvimento a quem o Estado deveria tratar com mais cuidado e atenção. Destaque-se que há leis e regimentos que tratam, especificamente, dessa parte da sociedade: adolescentes na faixa etária de 12 a 18 anos. Nessa esteira, lembro que a adolescência constitui amplo tema de pesquisa nas ciências humanas. Isso, por conta das grandes mudanças biopsicológicas que 
envolvem as transformações físicas, psíquicas e comportamentais, assim como as socioculturais. Há um paradoxo entre o ser que é autônomo, consciente de seus atos no que se refere à conduta, à linguagem, à habilidade, à disciplina e o ser que é considerado indefeso, por ser imaturo, inimputável, vulnerável em seus sentimentos e emoções ao se tornar agressivo, triste, depressivo, contestador e, em alguns casos, delinquente.

Como professora de Língua Portuguesa do Colégio Militar de Brasília e por ter a oportunidade de contribuir para a formação de muitos adolescentes bem sucedidos, senti a necessidade de contribuir, de alguma maneira, com o êxito de uma outra parcela da população que não consegue seguir esse mesmo caminho promissor dos alunos do CMB. Refiro-me aos adolescentes socioeducandos que se encontram em situação de reclusão. A propósito, essa preocupação me acompanha desde a época do meu curso de mestrado quando levei a cabo um estudo de caso realizado junto ao Centro de Internamento e Reeducação - Penitenciária Papuda (DF), na época, somente para adultos. ${ }^{1}$

Cabe, aqui, informar que parte dos adultos presos na Papuda eram reincidentes oriundos de Unidades de Internação para socioeducandos. Ao observar que, na maioria dos casos, não ocorria a ressocialização e a reeducação dos adolescentes nessas Unidades, tampouco nas penitenciárias, propus um sistema de educação a distância para presos com o intuito de haver uma reintegração social que perpassasse pela parte profissional, educacional e de saúde, o que me levou a publicar um livro sobre esse tema. ${ }^{2}$

Já no curso de doutorado, tive a oportunidade de buscar em Documentos Oficiais as lacunas existentes nas leis e nos regimentos que são voltados para adolescentes. Ademais, busquei fazer parte das rotinas dos socioeducandos para identificar o porquê de muitos adolescentes não serem ressocializados e reincidirem no crime, pois muitos deles são apreendidos nas Unidades de Internação para adolescentes, depois presos nas penitenciárias para adultos, e, em última hipótese, alguns morrem por duas causas principais: suicídio ou assassinato.

O propósito de comparar os regimentos e os relatos de adolescentes das duas instituições funda-se no objetivo operacional de tecer considerações a respeito do ethos discursivo dos entrevistados e, sobretudo, observar com que "vozes" seus próprios discursos se alinham e qual a interpretação de mundo deles em relação aos eventos disciplinadores das respectivas instituições. Além disso, o interesse em desenvolver uma pesquisa documental

\footnotetext{
${ }^{1}$ Conforme lembra Carvalho (2011, p.124), o Centro de Internamento e Reeducação, penitenciária para adultos, é popularmente conhecido como Papuda por estar localizado na Fazenda Papuda. Hoje é um complexo penitenciário chamado Complexo Penitenciário da Papuda.

2 CARVALHO, A.C.C. Reintegração dos presos por meio da educação a distância. Brasília: Editora Ser, 2011.
} 
para comparar Documentos Oficiais de duas instituições oficiais do governo, a Unidade de Internação de Santa Maria (UISM), no Distrito Federal, e o Colégio Militar de Brasília (CMB), ocorreu porque ambas possuem, em seu cerne, o discurso disciplinador, fator que constitui uma ligação entre as duas instituições, como forma de (re)educar o adolescente. ${ }^{3}$ Trata-se de duas instituições públicas que, embora sejam guiadas pelos mesmos princípios legais, no que concerne à educação e estejam alinhadas de modo paralelo em termos de princípios cívicos, morais, disciplinares, de inserção cultural, apresentam práticas sociais diferenciadas e se configuram distantes em seus respectivos regimentos internos. Resulta que ambas, apesar de contemplarem a Constituição Federal de 1988 (art. 227) e, sobretudo, o Estatuto da Criança e do Adolescente de 1990 (ECA), afastam-se em termos jurídicos no seguinte: uma encontra-se regida por medidas socioeducativas, que visam à educação como método de (re)educação e reintegração social diante de transgressões infracionais de adolescentes, enquanto a outra se orienta por um regimento interno que visa à educação com disciplina para aquisição de saberes e ampliação de conhecimentos.

Ressalto que, pelo fato de existirem dois contextos totalmente diferentes na tese e por eu estar focando uma faixa etária específica nas duas instituições, os adolescentes, aqui, serão tratados por socioeducandos/adolescentes em situação de reclusão e estudantes/alunos. Esses termos serão utilizados não por uma questão de discriminação ou de exclusão, mas, sim, pela necessidade de se evitar ambiguidades no decorrer do texto.

Esta tese é composta de cinco capítulos, além da presente apresentação e das considerações finais. No primeiro capítulo, ADOLESCENTES E CONTEXTOS INSTITUCIONAIS, contextualizo a pesquisa e abordo questões referentes a adolescentes, à identidade e ao discurso disciplinador. Em seguida, apresento as duas instituições em foco: a Unidade de Internação de Santa Maria e o Colégio Militar de Brasília. Na terceira seção, discuto o tema referente a adolescentes e ao sistema educacional: uma lacuna a ser preenchida.

No capítulo 2, DA INTERIORIDADE À EXTERIORIDADE DA LINGUAGEM SOB UMA PERSPECTIVA SOCIAL, apresento as duas propostas teóricas que constituem os pilares básicos da tese. A Análise de Discurso Crítica (ADC), na vertente proposta por Fairclough (2001, 2003, 2006, 2010), para quem linguagem e sociedade estão interconectadas dialeticamente e a Linguística Sistêmico-Funcional (LSF), teoria da linguagem desenvolvida por Halliday (1994) e ampliada em Halliday e Matthiessen (2004). Tomo como ponto de

\footnotetext{
${ }^{3}$ Conceituarei e detalharei discurso disciplinador no capítulo I: Adolescentes e contextos institucionais
} 
partida a interioridade da linguagem. Para tanto, faço uma breve retrospectiva histórica sobre os estudos da LSF. Em seguida, teço considerações a respeito da organização da linguagem por meio de estratos, bem como das variáveis do contexto de situação. Apresento as Metafunções e suas realizações léxico-gramaticais. Logo após, apresento a Metafunção Ideacional com seu Sistema de Transitividade, ou seja, a oração como representação; depois, a Metafunção Interpessoal, nomeada oração como troca e apresento a Metafunção Textual, ou seja, a oração como mensagem. Por último, faço uma abordagem sobre o Sistema de Avaliatividade. Em um segundo momento, parto para a dimensão da exterioridade da linguagem, em que apresento a ADC e as categorias de significados sugeridas por Fairclough (2003). Cabe destacar que faço um paralelo entre os grandes Eixos sugeridos por Foucault (1994) e os significados sugeridos por Fairclough (2003). Em seguida, discuto o poder disciplinador como prática social, os chamados discursos disciplinadores e apresento os modos operacionais da ideologia sugeridos por Thompson. Por fim, discuto o discurso como representação.

O Capítulo 3, DELINEAMENTO DO PERCURSO METODOLÓGICO, refere-se aos passos metodológicos que trilhei para a execução deste trabalho. Primeiramente, teço comentários a respeito da caracterização da pesquisa. Retomo o objetivo geral para detalhar os objetivos específicos, bem como as questões de pesquisa e o problema. Em seguida, caracterizo a pesquisa qualitativa e apresento as estratégias de investigação. Discorro sobre os dados em foco, que vão desde o corpus documental e os de natureza etnográfica, até a entrada no campo com as questões de ética. Logo após, apresento as entrevistas e elenco as perguntas feitas para os adolescentes da UISM e do CMB. Faço uma abordagem teórico-metodológica da ADC e da LSF. E, finalizando o capítulo, apresento o Programa WordSmith Tools v.5.0, desenvolvido por Scott (2010).

No capítulo 4, REPRESENTAÇÃO DOS ADOLESCENTES COMO OBJETO DO DISCURSO, faço a análise dos Documentos Oficiais. Inicialmente, enfoco a representação lexical configurada na referência aos adolescentes, desde o Código de Menores Mello Matos de 1927, até os referidos regimentos dos Colégios Militares e das Unidades de Internação. Com o auxílio da ferramenta WordSmith Tools, identifico as formas mais recorrentes de representação do adolescente em Documentos Oficiais. Nessa parte, realizo uma breve análise do gênero textual 'Regimento' como ação social. Sob a lupa do WordSmith Tools, aponto os componentes da transitividade dos regimentos das Unidades de Internação e dos Colégios Militares, bem como sua representação das ações. Dedico-me, em seguida, à análise documental dos regimentos na vertente da Linguística Sistêmico-Funcional e da Análise de 
Discurso Crítica. À luz dos pensamentos de Foucault, faço uma comparação das medidas disciplinares executadas pelas duas Instituições. Fecho o capítulo com os modos operacionais propostos por Thompson encontrados nos regimentos dos Colégios Militares e das Unidades de Internação.

O capítulo 5, A VOZ DOS ADOLESCENTES: UM DUETO EM CONTRASTE, trata da análise das representações linguístico-discursivas dos adolescentes das duas instituições: Colégio Militar de Brasília e Unidade de Internação de Santa Maria. As análises, em uma primeira etapa, com base nos textos das entrevistas realizadas com o(a)s aluno(a)s do CMB e com os socioeducando(a)s da UISM, concernem às representações linguístico-discursivas inerentes aos adolescentes dos dois contextos, da UISM e do CMB, as quais me permitem elencar as categorias linguístico-discursivas mais recorrentes nos relatos dos estudantes e dos socioeducandos, bem como discernir em que momento os discursos dos adolescentes se alinham e onde se afastam. Em segunda etapa, enfoco, nas análises, o Sistema de Avaliatividade e seus subsistemas, divididas em duas partes: a primeira, em textos escritos por adolescentes em situação de reclusão e relatos orais de estudantes do CMB com a temática referente à redução de maioridade penal e, a segunda, em um estudo contrastivo, concernente ao sistema socioeducativo, das leis, dos relatos de socioeducandos, do agente de polícia e pedagoga.

Nas CONSIDERAÇÕES FINAIS, teço algumas reflexões sobre os resultados alcançados neste trabalho de tese. Respondo as questões que nortearam a pesquisa e proponho sugestões que podem ser consideradas como forma de contribuição em favor de adolescentes em situação de vulnerabilidade e reclusão. Parafraseando Moreira (2013, p. 6), entretanto dando um outro enfoque pelo teor do trabalho, dirijo minhas palavras finais àqueles que elaboram os regimentos das Unidades de Internação, seja o Regimento Geral, seja das próprias Unidades (eixo do poder), aos que defendem as práticas sociais transformadoras (eixo do conhecimento) e aos que lutam pela igualdade e pela inclusão social, na linha dos direitos humanos (eixo da ética). Por fim, dedico esta tese àqueles que necessitam de um olhar mais atento da sociedade pela sua condição de fragilidade e de invisibilidade. 


\section{CAPÍTULO 1 - ADOLESCENTES E CONTEXTOS INSTITUCIONAIS}

Se a educação sozinha não transforma a sociedade, sem ela tampouco a sociedade muda. (FREIRE, 2000, p.67)

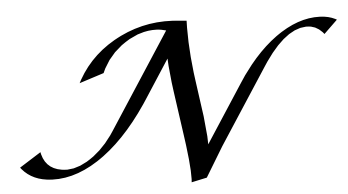

este capítulo, teço considerações a respeito da adolescência, bem como sobre identidade, discurso disciplinador e educação no Brasil. Na primeira seção, esclareço o que vem a ser adolescência e enfoco a questão da identidade e de discursos disciplinadores. A segunda seção é dedicada à apresentação dos dois contextos de situação: o Colégio Militar de Brasília e a Unidade de Internação de Santa Maria. A terceira seção envolve a relação entre os adolescentes e o sistema educacional.

\subsection{ADOLESCENTES, IDENTIDADE E DISCURSO DISCIPLINADOR}

A adolescência, como processo de desenvolvimento, é caracterizada em uma visão histórica e estereotipada, por transformações, variações de humor, mudanças hormonais e crescimento físico e psicossocial. Além disso, essa fase pode corresponder a uma busca de identidade e de papéis sociais pelos adolescentes. ${ }^{4}$ Esses papéis e funções lhes são conferidos, muitas vezes, pelo sistema familiar e pela sociedade em acordo com as necessidades demandadas e obrigações atribuídas. Pondera-se que é uma fase de construção pessoal que perpassa pela parte psíquica, social e histórica.

A família e a escola são (ou deveriam ser) veículos de transmissão para constituição dos papéis ou funções exercidas pelos adolescentes. Dessa forma, as vivências ocorridas aliadas às expectativas e exigências familiares, junto às disposições hereditárias, podem determinar o comportamento desse adolescente. Entretanto, faço uma reflexão a respeito da constituição de papéis dos adolescentes: e se o adolescente não tiver estrutura familiar, não tiver família e não tiver acesso à escola? Nesses casos, em uma perspectiva social própria, podem ser encontrados, em determinados contextos, adolescentes em situação de vulnerabilidade pessoal e/ou social.

\footnotetext{
4 Optei por utilizar o termo adolescente e não jovem para não causar dúvidas a respeito da faixa etária, pois no Estatuto da Juventude (2013), "são considerados jovens as pessoas entre 15 a 29 anos de idade". Norteio-me, aqui, pois, pelo art. $2^{\circ}$ do Estatuto da Criança e do Adolescente, o qual assegura que adolescente é aquele que pertence à faixa etária entre 12 e 18 anos.
} 
Os adolescentes, conforme Neto (2011, p. 23), podem ser classificados em três grupos, de acordo com o papel e a função na família e na sociedade: no primeiro, os que apesar de parecerem contrários ao sistema, agem no sentido de mantê-lo. São falsos rebeldes, mas não ameaçam o status quo..$^{5} \mathrm{Em}$ um segundo grupo mais numeroso, segundo o autor, estão os adolescentes que seguem normas impostas pela sociedade e vivem em harmonia com os adultos. Esse é um exemplo provável de repetição de um determinado modelo. São, nesse caso, os que mantêm o status quo. E, por último, no terceiro grupo, estão os que reagem às imposições do sistema social e familiar e não aceitam papéis impostos, com tentativas de mudança.

Nesse último grupo, encontram-se os inadaptados sociais, que são pessoas incapazes ou com muita dificuldade para se ajustarem ao grupo social e que se caracterizam por se rebelarem contra as leis e as normas, bem como por fazerem suas próprias regras. Em tal caso, são considerados rebeldes. Inserem-se, nesse grupo, os associais, que, além de não se submeterem às ordens sociais e não se ajustarem às normas postas, ainda "perturbam ou danificam os interesses da comunidade" (BIZATTO; BIZATTO, 2014, p. 86). Há, também, os pré-delinquentes, os quais estão fora da faixa etária de punição regular, mas são considerados antissociais e com tendências a práticas infracionais. E, por fim, encontram-se os delinquentes, que costumam viver em conflito tanto com a família e com a situação social existente quanto em conflito com eles mesmos. Dessa forma, para os autores Bizatto e Bizatto (2014), o adolescente que infringe as regras sociais de convivência é considerado um adolescente delinquente e também um "doente social", por merecer tratamento especial, pois suas potencialidades são voltadas para a delinquência.

Nessa vertente, aponto, neste trabalho, algumas razões para a existência de estigmas (GOFFMAN, 1975) que caracterizam adolescentes em associais, inadaptados sociais, prédelinquentes e delinquentes, tais como a falta de estrutura familiar, o uso de drogas, o descaso do poder público, a falta de educação de qualidade, problemas mentais. Note-se que esses comportamentos independem de classe social ou poder aquisitivo. Sendo assim, esses adolescentes podem estar em situação de vulnerabilidade social ou não, no sentido em que podem ter moradia ou não, podem ser excluídos socialmente ou não, podem viver em situação precária e em risco social ou não.

Porém, ressalto que, como consequência dos atos e do comportamento, esse grupo de adolescentes pode ser apreendido e cumprir medidas socioeducativas, se tiver mais de 12

\footnotetext{
${ }^{5}$ Status quo é uma expressão em latim que significa “estado atual”. No sentido do texto, significa situação atual.
} 
anos. Pontuo, entretanto, que esses casos permitem identificar uma forma de vulnerabilidade pessoal, em grande parte, conjugada à vulnerabilidade social, o que desencadeia uma identidade enfraquecida. ${ }^{6}$

Nessa esteira, Castells (1999) sugere que as identidades organizam significados na medida em que papéis organizam funções. Para o autor, o conceito de papel social concebe a ideia de um palco, no qual atores sociais representam papéis, nos mais diversos palcos da vida. São exemplos, o papel desempenhado no trabalho, na família, na escola, na rua, no crime, nas Unidades de Internação, nos presídios. Ressalte-se que as identidades ocorrem dentro do discurso de alguém, cujo papel social implica uma função.

Nesse sentido, as identidades, por serem autoconstruídas em vista do processo social, são fontes mais importantes de significados do que os papéis. Essa autoconstrução da identidade é vista como uma metamorfose por Ciampa (1987), ou seja, uma constante transformação, como resultado provisório da intersecção entre a história da pessoa, seu contexto histórico e social e seus projetos. Portanto, identidade é a articulação entre igualdade e diferença, pois são adequadas e adaptadas às novas circunstâncias que surgem. Dessa forma, é construída a partir de elementos históricos, geográficos, institucionais e das relações de poder estabelecidas nos grupos sociais. Sendo assim, as identidades são construídas em suas práticas sociais e, portanto, não são fixas, porém se encontram em constante negociação.

Tomando por base a acepção acima de identidade de Castells e Ciampa, considero enfraquecidas as identidades dos socioeducandos. Isso, porque, de acordo com o que observei na Unidade de Internação de Santa Maria, as práticas sociais em que os adolescentes em situação de reclusão se encontram inseridos, antes de serem apreendidos, pareciam ser desfavoráveis, devido a sérios fatores de cunho social, tais como falta de estrutura familiar, traumas emocionais, condições precárias de sobrevivência, falta de instrução educacional, uma alimentação deficiente, sendo esse último uma importante razão para desenvolvimento o baixo cognitivo. Esses fatores são prováveis causas que podem propiciar o surgimento de identidades fragilizadas e enfraquecidas, porque contribuem para cenários inadequados à construção positiva de identidades fortalecidas. Essas identidades enfraquecidas e fragmentadas dos socioeducandos podem, entretanto, ser fortalecidas, com atividades pedagógicas na escola, esporte, cursos profissionalizantes e disciplina, dentro da Unidade de Internação, bem como com trabalho social feito com as famílias fora das Unidades.

\footnotetext{
6 Utilizo, aqui, o termo "vulnerabilidade pessoal" por pensar que quem está em estado de vulnerabilidade pessoal está suscetível a algum problema em um determinado momento de sua vida. No caso dos adolescentes inadaptados sociais, associais, pré-delinquentes e delinquentes, o comportamento leva à vulnerabilidade para atitudes negativas que poderão configurar na reclusão.
} 
As atividades pedagógicas e profissionalizantes poderão, dessa maneira, fornecer e reforçar os aspectos positivos de adolescentes na identidade que eles já possuem, para a formação de uma nova identidade. Por isso, pondero que a instituição exerce grande influência, no que se refere ao apoio educacional e à apresentação de importantes valores para se viver e conviver em sociedade. Muitos desses adolescentes encontram-se comprometidos psíquica e emocionalmente, conforme a experiência de vida de cada um em crer, na tenra idade em que se encontram, que seu futuro está comprometido, devido a fatos ocorridos e a ações que tenham realizado. Porém, reintero que, no que concerne aos adolescentes que cometem infrações e delitos, trata-se de identidades enfraquecidas que podem ser renegociadas e resgatadas caso haja um maior empenho para que sejam transformadas.

Segundo Hall (2006, p.6), a identidade está sendo discutida na teoria social, porque as velhas identidades, que por tanto tempo equilibraram o mundo social, estão em declínio, o que acarreta o surgimento de novas identidades. Essas transformações provocam uma fragmentação no indivíduo, visto, até então, como sujeito uno. Nessa perspectiva, as mudanças históricas tornam-se fundamentais para o surgimento de novas identidades, pois uma nova conjuntura sociocultural é originada e transformada de tempos em tempos, o que, consequentemente, causa frequentes mudanças na identidade social. Essas mudanças possibilitam que sejam estabelecidos novos papéis sociais, novos valores, novas crenças, novas visões de mundo.

Por outro lado, conforme sugerem Fairclough (2003) e Hall (2006), as identidades são construídas pela e na linguagem. A linguagem é socialmente construída e representada pela semiose. As identidades sociais ou a construção do $e u$ no discurso são redefinidas e reconstruídas por meio de um processo dialético entre o discurso e as estruturas de dominação social (FAIRCLOUGH, 2001). Nas palavras de Silva T. (2009),

A identidade não é uma essência; não é um dado ou um fato - seja da natureza, seja da cultura. A identidade não é fixa, estável, coerente, unificada, permanente. A identidade tampouco é homogênea, definitiva, acabada, idêntica, transcendental. Por outro lado, podemos dizer que a identidade é uma construção, um efeito um processo de produção, uma relação, um ato performativo. A identidade é instável, contraditória, fragmentada, inconsistente, inacabada. A identidade está ligada a estruturas discursivas e narrativas. A identidade está ligada a sistemas de representação. A identidade tem estreitas conexões com relações de poder (SILVA, 2009, p. 96- 97). 
Ressalte-se que o conceito de identidade está diretamente relacionado às estruturas de poder na sociedade e, em decorrência dessa noção, a ADC busca compreender suas relações com o discurso. Dessa forma, a Análise do Discurso Crítica procura destacar que manifestações linguísticas podem ter diferentes sentidos e, assim, interferem na aceitação ou não de quem as recebe. O que, por sua vez, pode ser praticado por uma visão singular de mundo, como ocorre, por exemplo, com o discurso disciplinador, manifestação linguística aqui enfocada, abordada detalhadamente no capítulo 2.

Entende-se por discurso disciplinador a prática de elementos de ordem do discurso que costumam refletir práticas sociais reguladoras de conduta e comportamento no cumprimento de normas e regras, com tais elementos encontrados e configurados em representações linguístico-discursivas. ${ }^{7} \mathrm{O}$ discurso disciplinador, nesta tese, é aplicado a adolescentes em dois contextos diversos de duas instituições: Unidade de Internação de Santa Maria e Colégio Militar de Brasília, ambos no Distrito Federal, em uma relação assimétrica de poder.

\subsection{AS DUAS INSTITUIÇÕES EM TELA}

Esta seção mostra os dois locais onde foi realizada a geração de dados. As duas instituições que compõem o estudo da tese são o Colégio Militar de Brasília e a Unidade de Internação de Santa Maria. Ambas são públicas e, embora estejam alinhadas em termos de princípios cívicos, morais, de inserção cultural, distanciam-se em suas práticas sociais, pois o CMB envolve práticas ampliadas de distribuição de saberes e a UISM envolve práticas socioeducativas. Comecemos pelo Colégio Militar de Brasília, uma das instituições militares de ensino do Distrito Federal.

\subsubsection{Colégio Militar de Brasília}

O Colégio Militar de Brasília é um colégio da rede pública federal ministrado em consonância com a Legislação Federal da Educação Nacional. O CMB obedece às leis e aos regulamentos em vigor no Exército, naquilo que lhe for cabível, em especial às normas e diretrizes do Departamento de Ensino e Pesquisa (DEP), órgão gestor da linha de ensino no Exército. Gouveia (1997, p. 261) destaca que "para além de serem uma formalização do indivíduo no seio das relações de poder da instituição, os regulamentos militares visam também à formalização da disciplina no seio do sistema dos conceitos formadores da

\footnotetext{
${ }^{7} \mathrm{O}$ conceito de discurso disciplinador foi elaborado pela autora.
} 
instituição". Ressalte-se que, nesse sistema, a disciplina e a hierarquia são extremamente importantes nas práticas sociais dos estudantes.

\section{Fotografia 1.1 - Colégio Militar de Brasília}

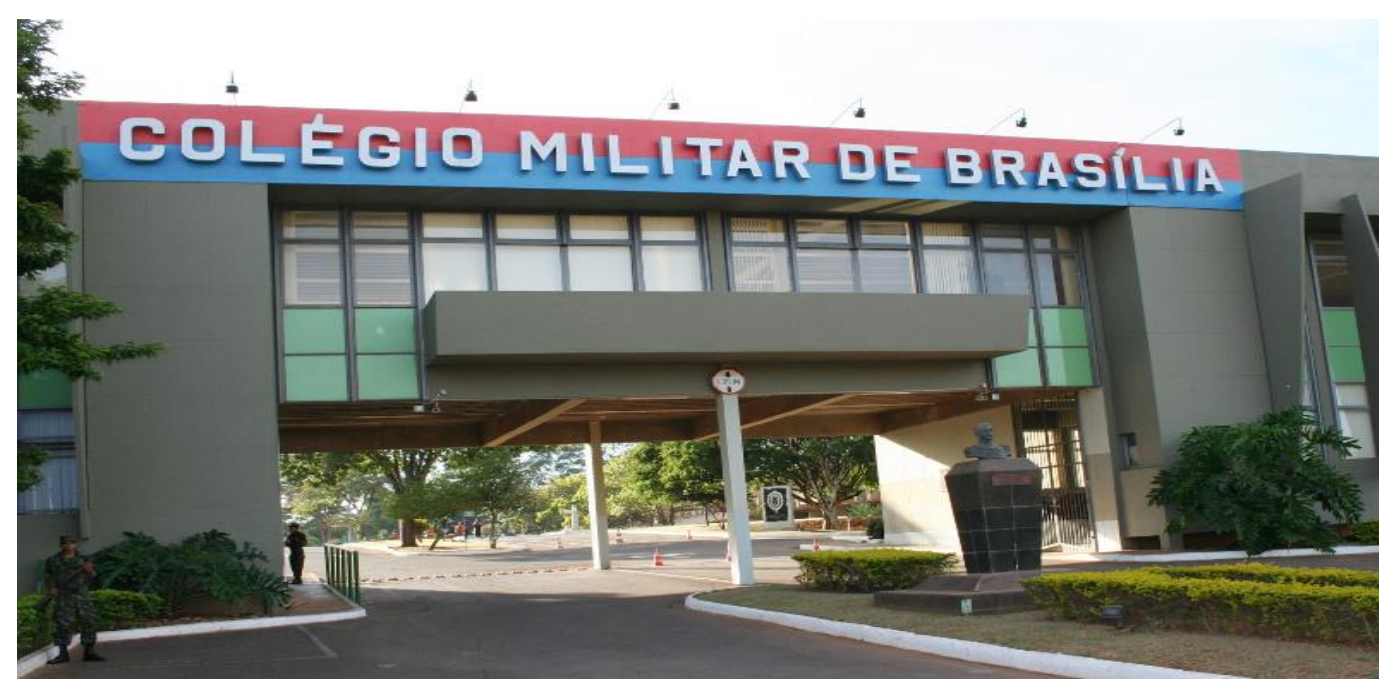

Fonte: www.cmb.eb.br/imagens

Nessa instituição, há uma a cadeia de gêneros documentais, dentre os quais se encontram o Regulamento dos Colégios Militares (R-69) e o Regimento Interno dos Colégios Militares (RICM). Esse último documento apresenta tópicos a respeito de conduta, comportamento, perfil e vestuário do aluno. Esses documentos constituem parte documental a ser analisada nesta pesquisa. O CMB tem, neste ano de 2016, um efetivo de 2.708 alunos, sendo 1460 do sexo masculino e 1248 do sexo feminino, como se pode observar no Quadro abaixo.

Quadro 1.1 - Demonstrativo de efetivo de alunos/ano no CMB

\begin{tabular}{|l|c|c|}
\hline Série/Ano & Masculino & Feminino \\
\hline $1^{\circ} / 3^{\circ}$ fundamental & - & - \\
\hline $4^{\circ} / 5^{\circ}$ fundamental & - & 94 \\
\hline $6^{\circ}$ fundamental & 114 & 120 \\
\hline $7^{\circ}$ fundamental & 150 & 155 \\
\hline $8^{\circ}$ fundamental & 181 & - \\
\hline
\end{tabular}




\begin{tabular}{|l|c|c|}
\hline Série/Ano & Masculino & Feminino \\
\hline $9^{\circ}$ fundamental & 235 & 197 \\
\hline $1^{\circ}$ ano ensino médio & 262 & 295 \\
\hline $2^{\circ}$ ano ensino médio & 260 & 164 \\
\hline $3^{\circ}$ ano ensino médio & 258 & 1248 \\
\hline Total & 1460 & 223 \\
\hline
\end{tabular}

Fonte: Quadro elaborado pela autora com dados cedidos pela seção técnica do CMB (8/08/2016)

Como observado no Quadro 1.1, o Colégio Militar tem um total de 2.708 alunos. Os anos escolares são divididos em anos do ensino fundamental e do médio. O ensino fundamental vai do $6^{\circ}$ ao $9^{\circ}$ ano e é dividido da seguinte forma: $6^{\circ}$ ano, com seis turmas; $7^{\circ}$ ano, com oito turmas; $8^{\circ}$ ano, com dez turmas; $9^{\circ}$ ano, com treze turmas. Já o ensino médio, vai do $1^{\circ}$ ano ao $3^{\circ}$ e é dividido da seguinte maneira: $1^{\circ}$ ano, com quatorze turmas; $2^{\circ}$ ano, com quinze turmas e o $3^{\circ}$ ano, com quinze turmas.

\subsubsection{Unidade de Internação de Santa Maria}

A UISM é uma instituição pública que envolve práticas socioeducativas, uma vez que existe para, em princípio, reintegrar na sociedade adolescentes em conflito com a lei, oriundos, em sua maioria, de classes menos favorecidas. Nessa instituição, há uma pequena escola e uma biblioteca e, por enquanto, uma oficina de pintura utilizada por somente seis socioeducandos. A quantidade de adolescentes do sexo masculino em situação de reclusão é bem maior que a do sexo feminino. O efetivo de adolescentes atendidos na Unidade de Internação, até o mês de agosto de 2016, somava 125 socioeducandos, sendo a maioria do sexo masculino (116) e somente nove do sexo feminino.

Desse efetivo, a maioria está cursando o $6^{\circ} / 7^{\circ}$ ano do ensino fundamental. Abaixo, pode-se observar a escolaridade dos socioeducandos na UISM em agosto de 2016.

\section{Quadro 1.2 - Demonstrativo de efetivo de alunos/ano na escola da UISM}

\begin{tabular}{|l|c|c|}
\hline Série/Ano & Masculino & Feminino \\
\hline $1^{\circ} / 3^{\circ}$ fundamental & 04 & 02 \\
\hline $4^{\circ} / 5^{\circ}$ fundamental & 10 & 01 \\
\hline $6^{\circ} / 7^{\circ}$ fundamental & 49 & \\
\hline
\end{tabular}




\begin{tabular}{|l|c|c|}
\hline Série/Ano & Masculino & Feminino \\
\hline $8^{\circ} / 9^{\circ}$ fundamental & 37 & 05 \\
\hline $1^{\circ}$ ano ensino médio & 12 & - \\
\hline $2^{\circ}$ ano ensino médio & 1 & - \\
\hline $3^{\circ}$ ano ensino médio & - & 09 \\
\hline Total & 113 & 01 \\
\hline
\end{tabular}

Fonte: Quadro elaborado pela autora com dados cedidos pela coordenação da UISM (09/08/2016)

Conforme o Quadro 1.2, no dia 09 de agosto, havia 125 socioeducandos na UISM. Na escola da Unidade de Internação, os anos escolares são divididos em anos da alfabetização, ensino fundamental e médio. A alfabetização vai do $1^{\circ}$ ao $5^{\circ}$ ano. $\mathrm{O}$ ensino fundamental vai do $6^{\circ}$ ao $9^{\circ}$ ano e é dividido da seguinte forma: $6^{\circ} / 7^{\circ}$ ano, com duas turmas; $8^{\circ} / 9^{\circ}$ ano, com duas turmas, $1^{\circ}$ ano do ensino médio com três turmas e, segundo a listagem e relato de adolescente, nenhuma de $2^{\circ}$ ano.

O sistema de séries, na UISM, funciona de acordo com o Programa para Avanço das Aprendizagens Escolares (PAAE). Nesse programa, optou-se por focar o público do ensino fundamental, pois foi nessa modalidade que se pôde observar o maior índice de estudantes com defasagem idade/ano. Dessa forma, os socioeducandos que estão cursando o ensino fundamental fazem duas séries juntas, ao mesmo tempo. Ressalte-se, porém, que os estudantes do $5^{\circ}$ ano não alfabetizados podem participar da turma de alfabetização nomeada pelo programa de Em Processo de Alfabetização.

Observe-se que há dezesseis adolescentes em processo de alfabetização e cinquenta socioeducandos no $6^{\circ} / 7^{\circ}$ anos, o que denota uma baixa escolaridade na Unidade, devido à questão da defasagem de idade e ano escolar. Essa defasagem escolar, em decorrência do abandono do estudo pelo adolescente, ocorre por diversas razões, dentre as quais se destacam a falta de estrutura familiar, o desinteresse pela escola e pelo estudo, as influências de amizades e, também, não menos importante, o consumo de drogas. 


\section{Fotografia 1.2 - Unidade de Internação de Santa Maria}

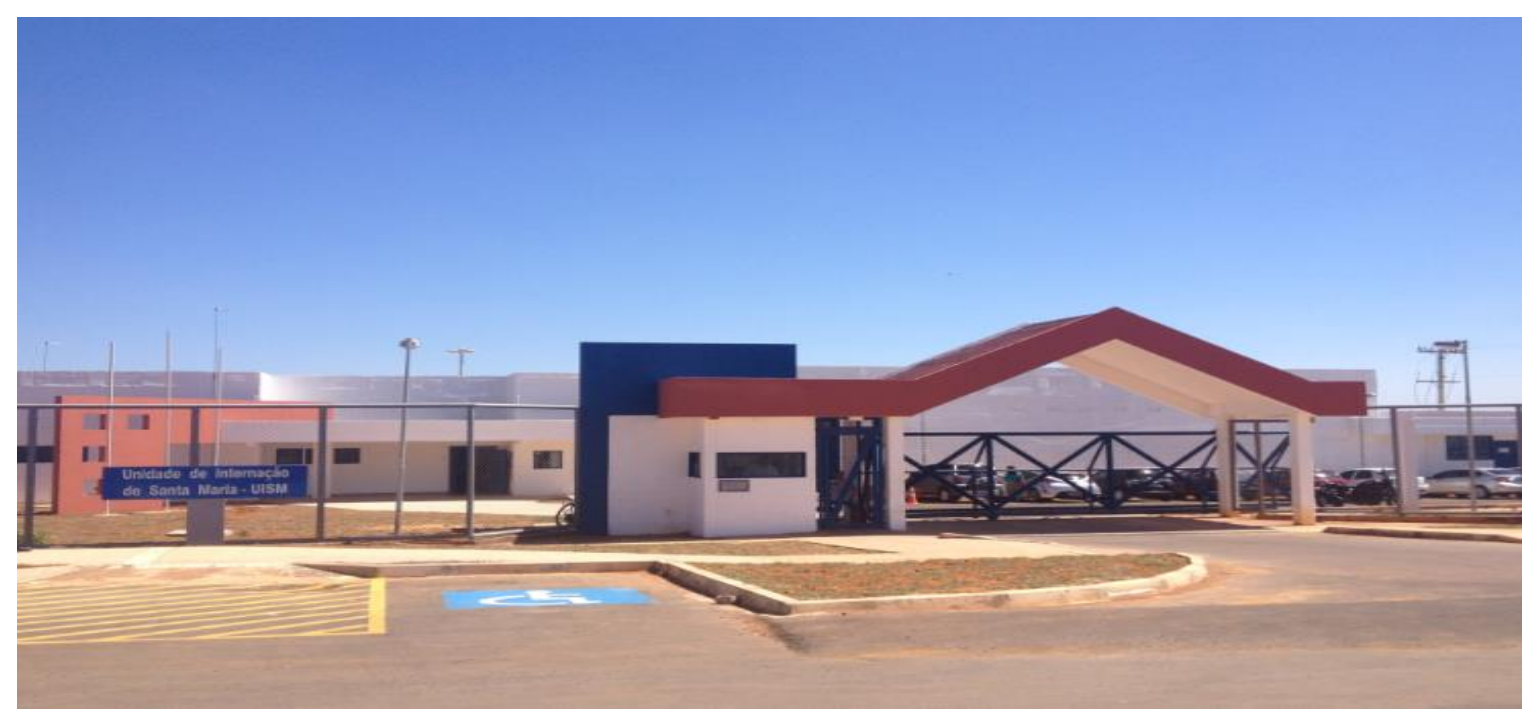

Fonte: fotografia tirada pela autora

Referindo-se ao encarceramento, Garland (2008, p. 422) sugere que esse sistema funciona como uma segregação de tipos específicos de pessoas, as quais são, em sua maioria, jovens do sexo masculino, que têm sua exclusão econômica e social efetivamente escamoteada por seu status criminal, informação que pode ser corroborada com o estudo realizado e informações colhidas na UISM.

\subsection{ADOLESCENTES E O SISTEMA EDUCACIONAL: UMA LACUNA A SER PREENCHIDA}

O Brasil possui uma população de aproximadamente 204 milhões de pessoas (IBGE, 2015), das quais 60 milhões têm menos de 18 anos de idade, o que equivale a quase um terço de toda a população de crianças e adolescentes da América Latina e do Caribe. Nesse contexto, entretanto, crianças e adolescentes crescem e estão, muitas vezes, em situação de vulnerabilidade no que diz respeito às violações de direitos, à pobreza, à desigualdade e à iniquidade no País.

Segundo dados da Unicef (2015), 29\% da população brasileira encontra-se na linha da pobreza, mas, entre as crianças, estatisticamente, esse número chega a 45,6\%. Na região do Semiárido, por exemplo, onde vivem 13 milhões de crianças, mais de $70 \%$ das crianças e dos adolescentes são classificados como pobres. No país, há uma estimativa de 21 milhões de adolescentes brasileiros na idade de 12 a 17 anos, faixa etária contemplada nesta tese. ${ }^{8}$

8 Ressalte-se que o art. $2^{\circ}$ da Lei $n^{\circ}$ 8.069/90, do Estatuto da Criança e do Adolescente, considera criança a pessoa de até 12 anos de idade incompletos e o adolescente é aquele que tem entre 12 e 18 anos de idade incompletos. 
Desses, de cada 100 estudantes que entram no ensino fundamental, apenas 59 terminam a $8^{\text {a }}$ série $/ 9^{\circ}$ ano e apenas 40 , o ensino médio.

Essa evasão escolar e a falta às aulas resultam de diferentes razões, como a violência, o desinteresse pela escola, a gravidez na adolescência, a necessidade de ajudar no suprimento de famílias de baixa renda e a falta de estrutura e proteção familiar. De acordo com Amin (2013), a evasão é antissocial, pois a criança, ou o adolescente despreparado, sem formação ou malformado, poderá se transformar em um adulto marginalizado, desempregado ou subempregado. Esse cenário serve para desvelar a negligência e a omissão tanto do Estado, quanto de parte sociedade e das famílias desses adolescentes, pois, apesar de existir a adoção de medidas judiciais e extrajudiciais para garantia do ensino fundamental para crianças e adolescentes com a participação da escola, comunidade e conselho tutelar, muitas vezes, tornam-se omissos e negligentes. Em termos de cidadania, esse déficit educacional propicia uma lacuna no aspecto social, o que agrava a situação de desigualdade social, de pobreza e de injustiça.

Essas desigualdades sociais, no Brasil, afetam diretamente as diversas condições de acesso à educação no país. De acordo com Moreira (2013, p. 18), quase todos os indicadores educacionais brasileiros evidenciam esse fato. Sendo assim, são percebidas desigualdades nas condições de acesso à educação e nos resultados educacionais das crianças, dos jovens e dos adultos brasileiros, o que acarreta a penalização de alguns grupos minoritários, da população mais pobre e do campo, dos adolescentes, jovens e adultos que não concluíram a educação devida na idade adequada.

Conforme já mencionado em Carvalho (2011, p. 29), “a educação não se efetua em uma realidade isolada, mas é uma das principais molas do sistema social”. Acrescento à educação, o esporte, pois “crianças e jovens que aprendem a participar do esporte também aprendem a obedecer às regras" (LINS, 2012, p. 82). A propósito, o processo educacional visa à integral formação da criança e do adolescente, buscando o desenvolvimento, seu preparo para o pleno exercício da cidadania e para o ingresso no mercado de trabalho de acordo com o artigo 205 da Carta Magna. Nessa direção, o direito à educação deve ser assegurado, como elemento de ressocialização, aos adolescentes em situação de reclusão, provisoriamente ou internados, ou em medida socioeducativa, nas variadas faixas etárias e níveis de instrução.

A educação é uma prática social. Portanto, essa prática educativa, enquanto prática social historicamente e culturalmente situada, é constituída por práticas discursivas que atuam no desenvolvimento dos sujeitos, envolvendo ação e interação, relações sociais e pessoas (com crenças, valores, atitudes, histórias), mundo material e discurso (FAIRCLOUGH, 2003). 
Ou seja, a educação ocorre no "contato com os outros, e as potencialidades e as falibilidades das pessoas moldam a extensão e a textura do crescimento de cada um" (STAINBACK, 1999, p. 64). Por isso, pondero que educação não é somente transmissão de conhecimento de disciplinas escolares, mas é também a transmissão de um conjunto de princípios e valores como afeto, respeito, construção da autoestima e autoconfiança, cidadania, ética, conduta.

Nesse sentido, a noção de prática pode indicar tanto uma ação social concreta e singular em determinado tempo e em algum local em particular, como também algo que já foi consolidado dentro de determinada permanência. É certo que a educação não é a panaceia para todos os problemas do País, pois se interceptam fatores econômicos, políticos e sociais, mas pode ser uma forma de extinguir ou minimizar muitos deles, como o valor social da desigualdade, da segregação, da exclusão e, consequentemente, diminuir o número efetivo de internações de adolescentes infratores.

\section{Algumas considerações}

Os temas apresentados, neste capítulo, permitiram colocar em destaque alguns aspectos que marcam a fase da adolescência. Buscou-se tratar a identidade como sendo construída em suas práticas sociais e, portanto, móvel e em constante negociação. Nessa perspectiva, considerei as identidades dos adolescentes em situação de reclusão como enfraquecidas, porém fiz a ressalva de que elas podem ser fortalecidas.

Além disso, caracterizei discurso disciplinador como a prática de elementos de ordem do discurso que costumam refletir práticas sociais reguladoras de conduta e comportamento no cumprimento de normas e regras, com tais elementos encontrados e configurados em representações linguístico-discursivas. Ademais, foram destacados os dois contextos da pesquisa: o Colégio Militar de Brasília e a Unidade de Internação de Santa Maria. Por fim, foram feitas considerações a respeito de educação, importante instrumento para minimizar a vulnerabilidade social, percebida como uma prática social.

O próximo capítulo encontra-se dedicado à interioridade da linguagem representada pela Linguística Sistêmico-Funcional, bem como da exterioridade da linguagem, realizada, aqui, pela Análise de Discurso Crítica. 


\section{CAPÍTULO 2 - DA INTERIORIDADE À EXTERIORIDADE DA LINGUAGEM SOB UMA PERSPECTIVA SOCIAL}

Viver significa participar do diálogo: interrogar, ouvir, responder, concordar, etc. Nesse diálogo, o homem participa inteiro e com toda a vida: com os olhos, os lábios, as mãos, a alma, o espírito, todo corpo, os atos. Aplica-se totalmente na palavra, e essa palavra entra no tecido dialógico da vida humana.

(BAKHTIN, 2003, p. 348)

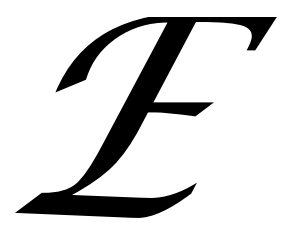

ste capítulo espelha uma relação dialógica, uma vez que são enfocadas para balizar o presente trabalho as duas propostas teórico-metodológicas escolhidas: a Análise de Discurso Crítica (ADC), na vertente proposta por Fairclough (2001, 2003, 2006, 2010), para quem linguagem e sociedade estão interconectadas dialeticamente e a Linguística Sistêmico-Funcional (LSF), teoria da linguagem desenvolvida por Halliday (1994) e ampliada em Halliday e Matthiessen (2004). Almeja-se conjugar a ADC à LSF, porque, em ambas, pode-se trabalhar o lado social da linguagem (discurso) em uma macro-análise sem que se perca a dimensão da interioridade (gramática) em uma micro-análise.

\subsection{DA INTERIORIDADE DA LINGUAGEM}

A Linguística Sistêmico-Funcional equivale a uma teoria linguística geral do funcionamento da linguagem humana, concebida a partir de uma abordagem descritiva. De acordo com Gouveia (2009, p. 14), é "uma teoria de descrição gramatical, uma construção teórico-descritiva coerente que fornece descrições plausíveis sobre o porquê de a língua variar em função de e em relação com grupos de falantes e contextos de uso". Contudo, além de ser uma teoria de descrição gramatical, ela propicia instrumentos de descrição, uma técnica e uma metalinguagem que são úteis para a análise de textos.

A LSF tem como precursor o linguista britânico Michael Alexander Kirkwood Halliday, organizador e estruturador da Gramática Sistêmico-Funcional, na obra $A n$ Introduction to Functional Grammar (1985), considerada a base dos estudos da LSF. Para formular sua teoria, Halliday teve influências dos fundamentos sistêmico-estruturais desenvolvidos por J. R. Firth, da teoria estrutural de Louis Trolle Hjelmslev, assim como da Escola de Praga, da tradição etnográfica de Boas-Sapir-Worf, do funcionalismo etnográfico e do contextualismo de Malinowski da década de 20. Sua teoria linguística tem grandes 
contribuições de pesquisadores como Geoff Thompson e Ruqaiya Hasan e tem sido desenvolvida por Jim Martin, Christian Mathiessen, Suzanne Eggins.

O termo Sistêmico-Funcional foi proposto por Halliday (1985) em uma direção funcionalista da investigação gramatical. A base repousa na noção de que é Sistêmico, porque a língua compreende recursos organizados em sistemas linguísticos interligados de significados, formas e expressões dentre os quais fazemos escolhas. Há, portanto, um sistema de redes de opções interconectadas, em níveis hierárquicos e constitutivos de estratos, que se realizam de modo integrado e simultâneo. É Funcional, pois explica as estruturas gramaticais no que tange ao significado e às funções que a linguagem desempenha no texto, ou seja, a forma do uso da língua. Ao ser concebido o princípio funcional do uso da linguagem como um meio que realiza propósitos comunicativos dos falantes, faz-se necessário edificar as relações entre os usos sociais da língua e o sistema. Por conseguinte, é chamada de SistêmicoFuncional devido ao fato de haver um amálgama entre aspectos referentes ao significado (base semântica), ao uso (funcional) e por considerar a existência de uma rede de sistemas que constituem uma língua (sistêmico).

Observa Neves (2010) que a gramática Sistêmico-Funcional fixa-se em uma noção de sistema tal qual um conjunto de escolhas da mesma maneira que uma estrutura linguística em uma organização de níveis distintos. Dessa forma emergem, segundo a autora, aspectos relevantes nessa proposição, tais como a multifuncionalidade dos itens, a prevalência do eixo paradigmático (o eixo das "escolhas"), a simultaneidade das seleções do falante (as seleções nos diversos subsistemas), a existência de um contínuo entre as categorias (a difusão de zonas).

Por outro lado, nas palavras de Silva (2003):

Ao que parece, o funcionamento social da língua está refletido, pelo menos em parte, nas estruturas linguísticas. Isso aponta para uma gramática de escolha paradigmática, que emerge da exterioridade dos usos comunicativos e que se coaduna com o caráter de interioridade de um sistema linguístico. Nesse sentido é que entende que o discurso molda a gramática e é por ela moldado na continuidade do processo das atividades linguísticas. (SILVA, 2003, p. 68-69)

Porém, cabe ressaltar que a gramática faz parte do conjunto de fenômenos linguísticos, mas não é o resultado do esforço teórico, e, sim, de um fenômeno natural (HALLIDAY, 1978; HALLIDAY; MATTHIESSEN, 1999; MATTHIESSEN; HALLIDAY, 2009). Por isso, desenvolve-se dentro de um contexto mais amplo, o da língua como um conjunto de recursos 
dispostos sistemicamente para a produção de significados. Na qualidade de fenômeno natural, a língua não pode, do ponto de vista sistêmico-funcional (HALLIDAY, 2003, vol. 3), estar apartada da totalidade dos outros fenômenos naturais. Sendo assim, a língua é interpretada como um sistema natural, de quarta ordem, superior (HALLIDAY; MARTIN, 1993). É importante esclarecer, neste momento, que os sistemas de primeira ordem são os físicos, os de segunda ordem são os biológicos, os de terceira ordem são sociais e, por fim, os de quarta, a língua.

São muitas as razões para a adoção de uma perspectiva sistêmica. Uma delas é que as línguas evoluem; elas não são projetadas. Além disso, os sistemas evolutivos não podem ser explicados simplesmente como uma soma de partes. Nosso pensamento tradicional sobre a linguagem, que é composicional, deve ser, se não substituído, pelo menos complementado por um pensamento 'sistêmico', por meio do qual buscamos compreender a natureza e a dinâmica do sistema semiótico como um todo. (HALLIDAY; MATTHIESSEN, 2004, p. 20)

A língua, na visão sistêmica, é compreendida como um recurso para construção e interpretação de significados em contextos sociais, o que a torna um sistema de escolhas, com a finalidade de os indivíduos desempenharem seus papéis sociais, em um meio social. Logo, é reconhecida como entidade viva, presente em grupos, lugares variados, eventos diversos. Por isso, na LSF, não se analisa um texto observando-se somente os termos lexicogramaticais, uma vez que, segundo Meurer (2004, p. 134), “cada significado deve ser relacionado simultaneamente a rotinas sociais e a formas linguísticas". Esse panorama de conexões entre língua e aspectos de vida social vislumbra um ponto de vista a respeito da análise linguística sempre orientada para o seu caráter social do texto.

Os estudos da linguagem, na vertente sistêmico-funcional, buscam entender o uso que o homem faz da língua como recurso para construção e interpretação de significados em contextos sociais, tendo em vista os textos possuírem particularidades e especificidades quanto à construção, à intencionalidade e aos efeitos desejados nos momentos de produção e recepção em suas práticas sociais. Kress $(1989$, p. 18) argumenta que a língua sempre ocorre como texto, e não como palavras e frases isoladas. De uma perspectiva estética, social ou educacional, é o texto que se configura como a unidade básica da língua. Ele surge em situações sociais específicas e é construído com propósitos específicos por um ou mais falantes e/ou escritores. Outrossim, os significados encontram nele sua expressão e são ajustados e negociados em situações concretas de troca social. Por esse motivo, os textos 
configuram-se como a forma material da língua; em particular, são os textos que realizam materialmente os discursos.

\subsubsection{Organização da linguagem por meio de estratos}

A língua proporciona a interação de uns com os outros, as relações interpessoais e mantém a ordem social e o poder que as subjaz. Quando a empregamos dessa forma, interpretamos e representamos o mundo para nós mesmos e uns para os outros. A língua, nesse sentido, é uma parte natural do processo de estar vivo; ela é usada para "armazenar" as experiências ao longo da vida, tanto a individual, quanto a coletiva. É ferramenta para representar o conhecimento, ou, em termos da própria língua, é ferramenta para construir significado (MATTHIESSEN; HALLIDAY, 2009, p. 41). Halliday (1978) concebe a língua como sócio-semiótica e sua concepção de experiência ou realidade, para ele, é socialmente construída, suscetível a processos de transformação. Nessa visão de semiótica social, a língua é explicada como a realização de significados inerentes ao sistema social. A língua, enquanto sistema semiótico, é constituída de camadas (ou níveis). Halliday (2003) assegura que:

De todos os sistemas semióticos, a língua é a principal fonte de poder. Seu potencial é infinito. Podemos caracterizá-la como um sistema correspondente a todos os nossos sistemas materiais - sempre capaz de se atualizar com as mudanças nas condições materiais de nossa existência. Mas, colocá-la dessa forma traz um privilégio excessivo ao material: expressa uma perspectiva tecnológica da condição humana. A língua não é o reflexo passivo da realidade material; é um participante ativo na constituição da realidade, manifestada em processos humanos, sejam no nível da consciência, das estruturas materiais ou no mundo físico que nos cerca; todos são o resultado de forças que são ao mesmo tempo materiais e semióticas. A energia semiótica é, necessariamente, concomitante ou complementar da energia material que produz mudanças no mundo. (HALLIDAY, 2003, p.4)

Esse sistema semiótico se baseia na gramática, evidenciada por uma organização em estratos (níveis) e pela diversidade funcional que têm entre si uma relação hierárquica e constitutiva. Ou seja, há uma seleção de elementos linguísticos para cada situação. No tocante à forma, de acordo com as necessidades dos falantes em contextos específicos, as escolhas expressam os significados almejados. Logo, os componentes fundamentais do significado na linguagem são componentes funcionais. É isso que explica o estudo da estrutura da língua, portanto, de toda a linguagem, a partir dos significados e não a partir dos elementos estruturais (BARBARA; MACÊDO, 2009). 
Para LSF, o sistema de escolhas tem como base os estratos cujas diferenças são evidenciadas, conforme a ordem de abstração. Isso posto, há uma sequência, em que um realiza o outro: os sistemas de sonoridade e grafia geram/realizam os sistemas léxicogramaticais, que, por sua vez, ocasionam o sistema de significados. Sendo assim, Chouliaraki e Fairclough (1999, p. 139) sugerem que "a organização em estratos da linguagem significa que a ligação entre os estratos de significado e os de expressão é mediada por um estrato que não se relaciona diretamente com o extralinguístico". Portanto, esse extrato é o da léxicogramática, como pode ser observado na Figura a seguir:

Figura 2.1 - Estratos do modelo de LSF

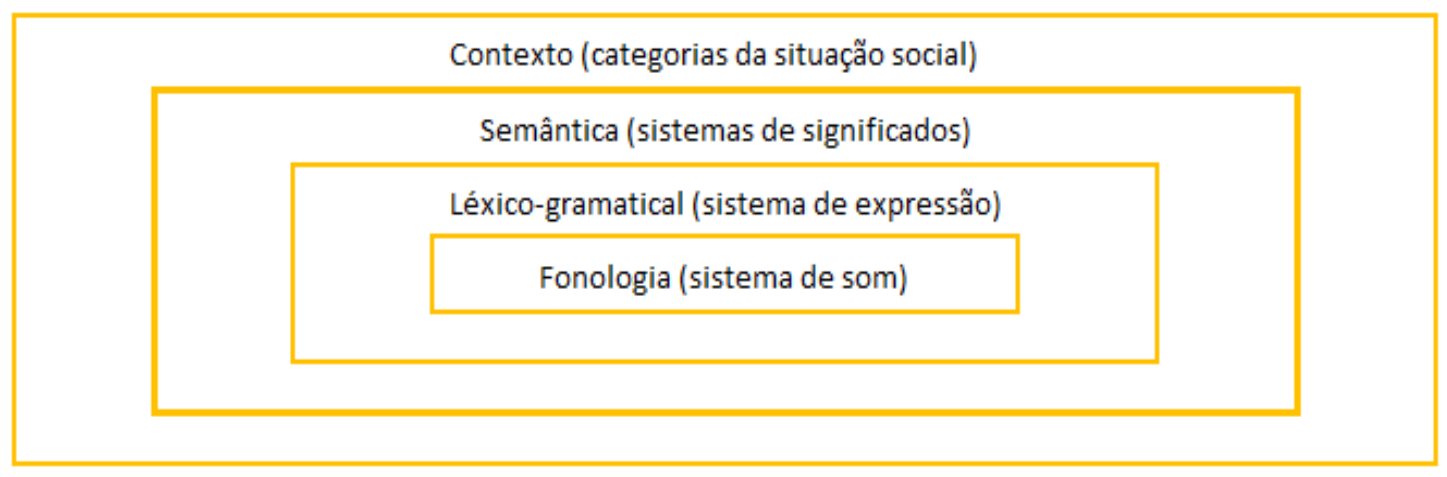

Fonte: adaptado Hasan y Perrert, 1994

Cabe ressaltar que, na LSF, o papel do contexto é imprescindível, bem como os significados escolhidos e atribuídos pelo usuário à sentença que ele produz. Dessa forma, conforme Martin, Matthiessen e Painter (2010), Halliday tinha como principal objetivo, ao escrever suas gramáticas, prover uma gramática geral para fins de análise e interpretação textual. Portanto, é "uma gramática que provê uma básica 'língua franca' para análise textual que trabalhe em um grande escopo de diferentes contextos; e é muito efetivamente organizada como ferramenta para esse fim” (MARTIN; MATTHIESSEN; PAINTER, 2010, p. 2).

O contexto de situação reporta-se, de forma sistemática, à organização funcional da linguagem, isto é, ao ambiente verbal e ao envolvimento social - a situação em que o texto está inserido. Esse contexto do texto, segundo Halliday e Hasan (1985, p. 46), é "o ambiente imediato em que o texto está realmente sendo trabalhado". Essa noção é utilizada para a explicação do porquê de algo ter sido dito ou escrito em uma situação particular e o que mais poderia se dizer ou escrever, mas não o foi. Nessa perspectiva, observa-se a impossibilidade 
de interpretação da mensagem sem o acesso aos elementos do contexto que estão representados nos atos de fala, que, como propõe Searle (1976), ainda que conclua a infinidade de atos de fala, categoriza-os em cinco grupos: assertivos (descrevem o mundo), diretivos (levam alguém a fazer algo), comissivos (comprometem-se a fazer algo), expressivos (expressam sentimentos e atitudes) e declarativos (produzem mudanças pelo enunciado).

Faz-se necessário destacar que, no estrato semântico, a linguagem desempenha três funções fundamentais: a representação de experiências (ideacional), o estabelecimento de relações com os outros e a troca de significados (interpessoal) e a organização dos significados em forma de texto (textual). Sendo assim, Halliday (1985) sugere a divisão da linguagem em metafunções, as quais implicam três significados realizados e decorrentes dos contextos social e cultural em que acontece a interação. Esses sistemas agrupam-se de três formas: a metafunção ideacional com o sistema de transitividade e o sistema de lógica; a metafunção interpessoal com o sistema de modo e o sistema de Avaliatividade; e, por último, a metafunção textual com o sistema de informação e o sistema de Tema e Rema.

A propósito, quando se fala em contexto de cultura, o estudo de Malinowski (1999) deve ser ressaltado em razão de ele ter sido precursor de um campo da antropologia social, que concebe a ideia de que o pesquisador de um grupo de pessoas deve observar a língua e os costumes socioculturais locais. Em trabalho de campo feito na Polinésia, o antropólogo, conforme lembra Neves (2010, p. 80), identificou três funções da linguagem, quais sejam: uma função pragmática (linguagem como forma de ação); uma função mágica (linguagem como meio de controle do ambiente); e uma função narrativa (linguagem como estoque de informação preservada na história), caracterizando, assim, a linguagem como multifuncional. Para ele, o contexto em que o texto se desenvolve está inserido no texto, isto é, o uso linguístico que constitui um texto corresponde a determinado contexto, pois há uma relação sistemática entre o meio social e a organização funcional da linguagem.

Relacionado ao ambiente sociocultural, o contexto de cultura refere-se a práticas mais amplas, com dimensão que abrange diferentes países, grupos étnicos, práticas institucionalizadas em grupos sociais, ideologia, além de convenções sociais e instituições. Segundo Motta-Roth e Herbele (2005, p. 15), o contexto da cultura é resultado da padronização do discurso em termos dos atos retóricos ou atos de fala realizados por meio da linguagem em circunstâncias específicas, com características retóricas recorrentes. A propósito, nas palavras de Barbara e Macêdo (2009): 
É a partir dos elementos da cultura que o falante seleciona os elementos de seu texto. O homem, situado histórica e socialmente numa cultura, seleciona, a partir dessa cultura, o modo como vai produzir texto, a forma como interagirá com os participantes da interação, tendo em vista um conhecimento, um conteúdo experiencial que será realizado com a seleção que fará. Textos terão características diferentes dependendo dos participantes e da finalidade a que sirvam (BARBARA; MACÊDO, 2009, p.93).

Com base nas afirmações anteriores, pode-se sugerir que um texto, portanto, terá um propósito, em uma situação específica, com características determinadas vinculadas a valores ideológicos e identitários. Sendo assim, há uma relação concreta entre o contexto de cultura e a noção de gênero, pois a finalidade e o significado de um texto, seja escrito ou falado, estão relacionados à sua produção.

\subsubsection{Variáveis do Contexto de Situação}

Na seção anterior, observou-se a importância dos dois contextos: o contexto de situação, que é um contexto imediato; e o contexto de cultura, mais amplo. Essas características, para Halliday (2002), estão intrínsecas ao texto, por haver uma dialética entre o texto e os contextos. Ambos são elementos relevantes na observação da linguagem, pois contribuem para que se compreenda como a língua é usada. Esses contextos, para Halliday (1973), distinguem o "potencial” (a gama de possibilidades disponíveis na linguagem contexto de cultura) e o "real" (a escolha entre as possibilidades - contexto de situação).

À vista dessa dialética, ocorre uma relação sistemática entre a organização da língua, ou seja, entre os três tipos de significados em que ela está estruturada e os elementos contextuais. Diante disso, existem três aspectos relevantes a serem observados: a) a natureza do processo, isto é, o que se está fazendo com ou por meio do discurso; b) as relações sociais entre os participantes do discurso; c) como se dá a interação, a atividade como evento social por exemplo, se coerciva, se persuasiva, se instrutiva. Essas três características correspondem a três funções expressas por meio de variáveis de registro, que devem caracterizar um contexto (HALLIDAY; HASAN, 1985, p. 45-46), como se pode ver abaixo:

a) campo (tipo de ação social ou sobre o que a interação trata), associada à função ideacional;

b) relação (relações sociais ou os papéis desempenhados, e as relações interpessoais presentes no discurso), associada à função interpessoal;

c) modo (contato e ação verbal ou como a língua é organizada para atingir os objetivos aos quais se destina), associada à função textual. 
Como sugere Halliday (1978, p. 143-145), campo, relação e modo, "tomados juntos, constituem a situação, ou o contexto de situação de um texto". É o que o autor concebe como "ambiente ou contexto social da linguagem", estruturando-se como "um campo de ação social significativa, uma relação de interação entre papéis, e um modo de organização simbólica".

O registro, então, descreve o impacto das dimensões do contexto imediato da situação de um evento no modo como a linguagem é usada (EGGINS, 1994), pois configura os significados diante da situação, com o intuito de interpretar o contexto social de um texto e a forma pela qual os significados são trocados (VIAN JR, 2001), visto que "toda língua funciona em contextos de situação" (HALLIDAY, 1998, p. 47).

Ressalte-se que, para Eggins e Martin (1997), o registro é originado nas escolhas feitas pelos falantes para representarem, por meio da linguagem, as realidades de mundo. Para os autores, "o conceito de registro é uma explicação teórica da observação do senso-comum de que nós usamos diferentemente a linguagem em situações distintas" (EGGINS; MARTIN, 1997, p. 12). Sendo assim, as variáveis de registro afetam nossas escolhas linguísticas, porque refletem três metafunções que representam escolhas semânticas dentro de um nível léxicogramatical que o usuário da língua utiliza em determinado contexto de situação (HALLIDAY; MATTHIESSEN, 2004), quais sejam: metafunção ideacional, metafunção interpessoal e metafunção textual (HALLIDAY, 1994).

\subsubsection{As Metafunções e suas realizações léxico-gramaticais}

Na LSF, os significados linguísticos são uma realização da lexicogramática. Logo, se um significado não pode ser construído pela lexicogramática de uma língua, então não pertence a essa língua. Por isso, Ghio e Fernández (2008, p. 91) argumentam que, “o significado linguístico não é um simples 'reflexo' ou um 'espelho' da realidade, mas, sim, uma 'interface' entre o mundo extralinguístico e forma linguística”.

Por meio da linguagem, as práticas comunicativas exercem, simultaneamente, três metafunções que estabelecem relações com a análise léxico-gramatical e têm a oração como unidade básica. O texto, na LSF, portanto, é multidimensional e realiza mais de um significado concomitantemente, conforme as metafunções que organizam de forma funcional a linguagem. Levando-se em conta essas observações, faz-se necessário esclarecer que o foco de análise em cada uma dessas metafunções difere, pois o sistema de realização léxicogramatical é diferente. Função, para Halliday (1985, p. 17), não é somente sinônimo de uso, mas, sobretudo, a propriedade fundamental da linguagem. 
A oração é também a unidade principal de processamento da léxico-gramática, porque, nela, os significados são mapeados numa estrutura gramatical integrada (HALLIDAY, 2004, p. 10). Nesse sentido, a oração é ao mesmo tempo uma representação, uma troca e uma mensagem, visto que ela é, enquanto estrutura gramatical, o resultado do mapeamento

simultâneo de, respectivamente, significados ideacionais, significados interpessoais e significados textuais (GOUVEIA, 2009).

Por isso, as metafunções desempenham a produção de significados ideacionais (oração como representação), interpessoais (oração como ato de fala) e textuais (oração como mensagem) e são realizadas por meio de três sistemas: sistemas de transitividade, sistema de modo e sistema temático (tema/rema) ou sistema de informação (dado/novo).

Ressalte-se que Fairclough (2001) se refere às funções hallidayanas quando faz alusão aos efeitos construtivos do discurso (identidade social, prática discursiva e prática social) e afirma que eles estão diretamente ligados à metafunção Interpessoal e à metafunção Ideacional.

\subsection{METAFUNÇÃO IDEACIONAL: A ORAÇÃO COMO REPRESENTAÇÃO}

A metafunção ideacional abrange dois componentes ou subfunções no interior de um segmento oracional, ou entre complexos oracionais: a experiencial e a lógica. A experiencial envolve a construção de um modelo de representação do mundo e é onde se encontram os processos de transitividade; já a lógica, compreende as relações lógico-semânticas hipotáticas e paratáticas entre complexos oracionais. Não obstante, esta subseção será dedicada ao componente experiencial, o qual projeta o Sistema de Transitividade.

No Sistema de Transitividade, encontram-se três componentes: processos (sintagmas verbais), participantes (sintagmas nominais) e circunstância (sintagmas adverbiais). Quanto a esses componentes, ressalte-se que o processo é realizado pelo verbo da oração, que pode exprimir ações, sentimentos, a existência; o participante é realizado por substantivos ou grupos nominais e pode ser ator, agente, meta, beneficiado, afetado entre outros; e a circunstância é realizada por advérbios ou sintagmas adverbiais. Em termos gerais, a transitividade constitui-se como o recurso linguístico "que dá conta de quem fez o quê a quem em que circunstâncias" (GOUVEIA, 2009, p. 30). A oração, na metafunção ideacional, é entendida como representação, ou seja, ela representa ou constrói os significados de nossa experiência, por meio do Sistema de Transitividade, no mundo exterior (social, físico ou substancial) e no mundo interior (psicológico ou da consciência). 
A propósito, para Halliday e Matthiessen (2004), existe um diferencial entre o que experienciamos ao agir no mundo exterior, que corresponde a ações, identificação ou eventos, e o que experienciamos no mundo de nossa consciência, aspectos constituintes de percepção, emoção, imaginação, lembranças ou reflexões. Segundo os autores, a partir da perspectiva ideacional, a linguagem constrói a experiência humana dentro de uma série de tipos de processos. Esta rede de sistemas (significado interno e externo) forma um espaço semiótico contínuo, no qual a língua é utilizada e organizada em configurações semânticas, que fornecem modelos ou esquemas para construir nossas experiências do que acontece ao nosso redor (HALLIDAY; MATTHIESSEN, 2004). Conforme sinaliza Silva (2013),

\footnotetext{
A função ideacional - como componente principal do significado linguístico - consiste, em parte, na expressão do conteúdo, da gramática da experiência do falante/escritor, conforme sugerem (Halliday \& Matthiessen, 2004), em relação ao mundo exterior, físico (do fazer), ao mundo das relações abstratas (do ser) e ao mundo interior, cognitivo (do sentir), ou seja, o mundo da consciência (SILVA 2013c, p. 91)
}

Portanto, para a LSF, o sistema gramatical da transitividade concebe o mundo de experiências internas e externas dentro de um conjunto de processos: processos material, comportamental, mental, verbal, relacional e existencial. Segundo Halliday (2004, p. 172), há os processos principais - material, verbal e relacional que seguem um continuum cíclico, no qual são separados por outros três processos - comportamental, verbal e existencial - os quais possuem características específicas em relação aos processos com que fazem fronteiras.

Isso pode ser observado na figura abaixo, batizada por Silva (2011) de Mandala da Gramática da Experiência, a qual faz alusão à Gramática da Experiência de Halliday. Segundo a linguista brasileira, a Mandala da Gramática da Experiência representa "uma aproximação metafórica da energia emanada dos centros geradores de nosso mundo conceptual e linguístico" (SILVA, 2013, p. 91), caracterizado por Halliday, pelos seis tipos de processos, cujos significados prototípicos, no interior dos símbolos sextavados, são constitutivos de pistas, tanto para a análise léxico-gramatical, quanto para a semântico-discursiva. Apreciemos a seguir: 
Figura 2.2 - Mandala da Gramática da Experiência

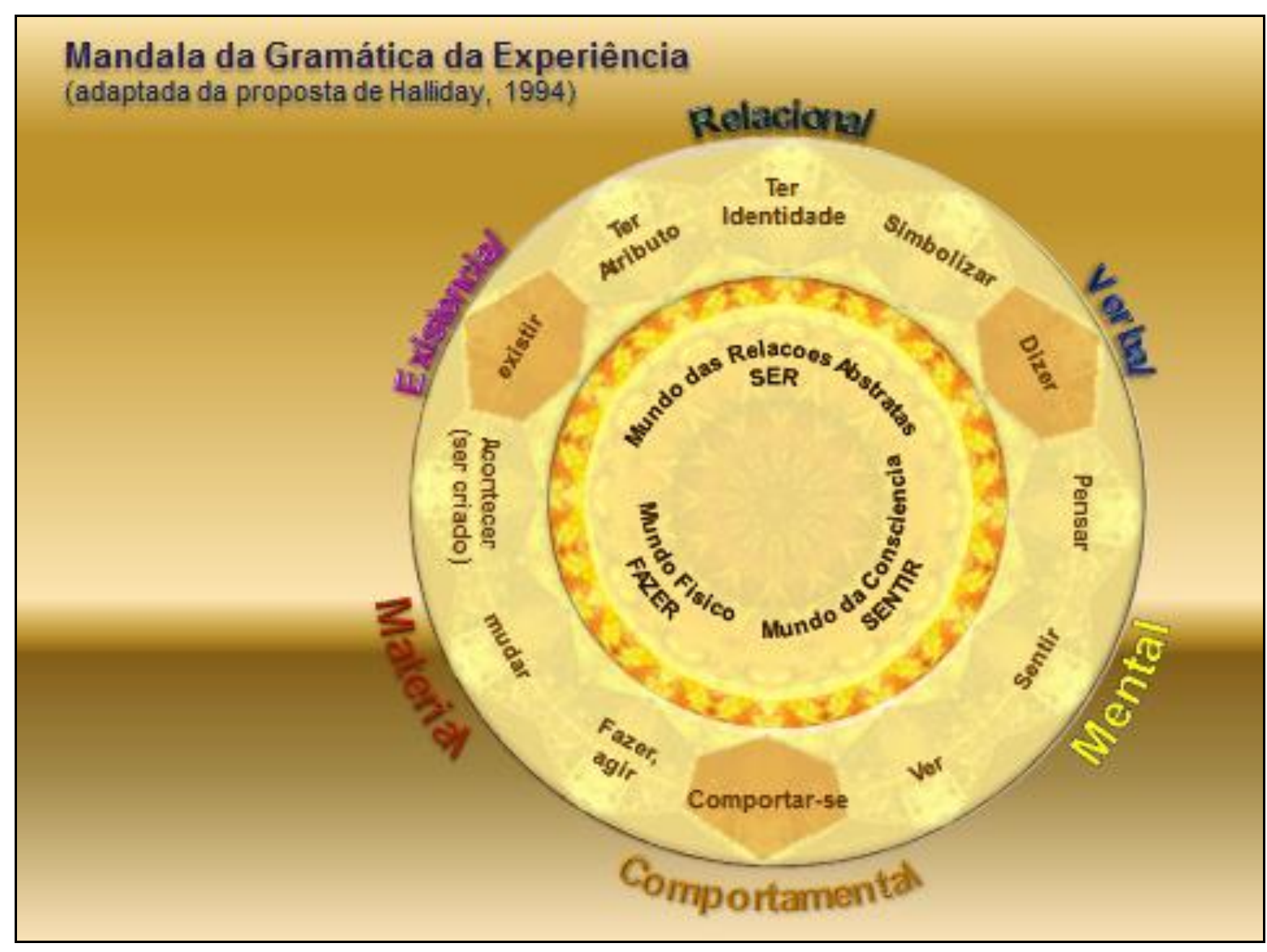

Fonte: Silva (2013a)

Cabe ressaltar que a Figura 2.2 traduz uma analogia sugerida por Silva (2011) com base em Halliday (1994), bem como em Halliday e Mathiessen (2004, p. 172), para explicar tipos de processo em português a partir de outra construção metafórica, a metáfora visual concreta de Halliday. Nela, podemos observar três níveis esféricos: o primeiro corresponde aos três mundos: o do SER, das relações abstratas; o do FAZER, o mundo físico; e o do SENTIR, o mundo da consciência. O segundo envolve o processo semiótico dos processos de transitividade. Já no terceiro, estão os processos primários e secundários do sistema de transitividade. Além disso, essa imagem reproduz a figura dos processos primários ou básicos, considerados básicos, (material, mental e relacional) e dos secundários ou intermediários (comportamental, verbal, existencial), haja vista se encontrarem mesclados, no que se refere ao significado, pela proximidade de fronteiras de sentido intercalados pelos processos básicos. Resulta que os significados prototípicos, exibidos no interior das formas sextavadas, constituem pistas tanto para análise léxico-gramatical quanto semântico- discursiva. Enquanto os três primeiros processos citados - materiais, mentais e relacionais - 
podem ser considerados básicos, os três últimos - comportamentais, verbais e existenciais costumam ser caracterizados como secundários, porque se encontram mesclados, em termos de significado(s), justamente pela proximidade das fronteiras de sentido intercaladas pelos processos básicos.

Conforme Halliday e Matthiessen (2004, p. 171) asseguram, “não há prioridade de um tipo de processo sobre o outro. Entretanto, eles estão ordenados”. Sobre essa ideia, trata-se de uma mescla resultante da preservação de traços semânticos de processos vizinhos, chamada de princípio linguístico de "indeterminação sistêmica" (HALLIDAY; MATTHIESSEN, 2004, p.173), o que vem a ser associado à variação funcional de sentido que as formas verbais podem apresentar de acordo com a contextualização. Nesse caso, o contexto e a semântica propiciam elementos para a determinação de um processo específico. Isso porque um mesmo grupo verbal é capaz de realizar processos diversos, dependendo das combinações léxicogramaticais e do contexto. Nessa linha, a Gramática da Experiência nos mostra o uso e a vivência da língua, pois envolve as escolhas lexicais e estruturais agregadas a valores culturais.

Como sugere Thompson (2004, p. 127), devem ser feitas as seguintes perguntas, ao se escolher a transitividade para analisar um texto: quais são os tipos de processos dominantes e por quê? Que tipos de participantes existem? Como esses participantes se comparam com as entidades e os eventos do "mundo real"? Quais são os tipos de participantes existentes (concretos ou abstratos)? Qual o papel deles na transitividade? Que tipos de circunstâncias são incluídas? O que é expresso como circunstância ao invés de fazer parte do núcleo (processo + participante)? Cabe ressaltar que, para o autor, as respostas poderão tornar a interpretação e a compreensão mais claras e verossímeis.

A seguir, serão apresentados os elementos que compõem o sistema de transitividade proposto por Halliday (1994) e Halliday e Matthiessen (2004). Alguns desses processos, bem como participantes e circunstâncias exemplificados nas subseções, serão apontados e discutidos empiricamente nos capítulos analíticos.

\subsubsection{PROCESSO MATERIAL}

São considerados materiais os processos relacionados ao fazer, a ações, fatos, eventos realizados no mundo físico. Nesse sentido, os processos materiais são responsáveis pela criação de uma sequência de ações concretas (HALLIDAY; MATTHIESSEN, 2004), ou também abstratas, sejam elas criativas ou de transformação. Dentre alguns exemplos, podem 
ser citados: assar, construir, aquecer, envelhecer, bater, chutar, alimentar, correr. Fazem parte das orações materiais: o Ator e a Meta. Esses participantes são grupos nominais que informam a respeito de lugares, pessoas e ideias envolvidas no processo em uma oração.

O Ator é quem realiza a ação e sua presença é obrigatória. Pode ser animado ou inanimado. Para Thompson (1996, p. 78), todo processo tem um Ator, mesmo que ele não seja mencionado na proposição. Halliday e Matthiessen (2004, p. 203) lembram que esse participante provoca o desenrolar do processo, através do tempo, conduzindo a um resultado diferente da fase inicial do desdobrar do processo. Sendo assim, há uma mudança no fluxo do evento. O processo pode ser inerente às orações transitivas (quando envolve dois participantes) ou às orações intransitivas (quando envolve um participante).

A Meta é o participante que sofre ou experimenta o processo; é aquele que é modificado pela ação, ou seja, o afetado pelo processo. Em termos da gramática tradicional, ele seria o Objeto Direto (EGGINS, 1994, p. 231). A ideia proximal para o participante seria algo como aquele ao qual o processo se estende. A noção de extensão, contudo, é a denominada, na terminologia clássica, de transitiva e intransitiva, da qual o termo transitividade é derivado. De acordo com essa teoria, o verbo fugir é nomeado intransitivo (não estendido) e o verbo pegar, transitivo (estendido) - ou seja, estendendo a alguma outra entidade. Vejamos nos excertos abaixo:

(1) Art. 43 Ofertar (processo material) regularmente atividades culturais, de esporte e lazer (Meta) na Unidade de Internação (Circunstância).

(Regimento Interno das Unidades de Internação do DF, Capítulo V - Das políticas sociais, Seção VI - Da Assistência Cultural, Esportiva e ao Lazer, p. 20, 2013)

(2) Art. 68 O Defensor Público (Ator) desenvolverá (processo material) suas atividades (Meta) nas Unidades de Internação (Circunstância) sempre que necessitar (Circunstância).

(Regimento Interno das Unidades de Internação do DF, Capítulo VI - Da segurança, Seção V - Acesso ao Defensor Público e ao Advogado particular, p. , 2013)

Os processos materiais podem ser concretos ou abstratos, como se pode observar nos exemplos abaixo:

(i) $\mathrm{O}$ vento (Ator) destruiu (processo material concreto) o trecho; seus argumentos (Ator) destruíram (processo material abstrato) sua teoria. 
Uma vez que conceitos de extensão, intransitivo (não estendido) e transitivo (estendido) são de base semântica, eles continuam aplicáveis a sentenças na voz passiva, em que a Meta assume a posição de sujeito, o que acarreta uma grande diferença, como mostram os períodos:

(i) O policial (Ator) perseguiu o adolescente.

(ii) $\mathrm{O}$ adolescente (Meta) foi perseguido.

Halliday e Matthiessen (2004) classificam os Processos Materiais em duas formas: Processo Material Criativo, aquele que traz a Meta à existência e Processo Material Transformativo, em que a Meta já existe.

(i) Ele traçou os objetivos. (O ato de traçar trouxe os objetivos à existência)

(ii) Ele destruiu os meus objetivos. (Os meus objetivos é a Meta; foram destruídos, mas eles já existiam)

Quando há somente um Ator, o Processo Material Criativo relata a participação do Ator na ação e o Processo Material Transformativo relata a mudança de estado feita pelo Ator. Na voz passiva, o Ator pode não estar explícito e a Meta é o sujeito.

\subsubsection{PROCESSO MENTAL}

Os processos mentais são processos de sentir (HALLIDAY, 1994, p. 112), pois são relativos à experiência do mundo da nossa consciência e à representação do nosso mundo interior (THOMPSON, 1996, p. 82). Nas conversações, os processos mentais se propõem a construir o mundo da consciência do falante, em um nível individual (HALLIDAY; MATHIESSEN, 2004). Dessa forma, objetivam a construção da própria consciência do falante. Sugerem Cunha e Souza (2007, p. 58), que por meio das análises dos processos mentais, é possível detectar que crenças, valores e desejos estão representados em um dado texto. Halliday e Matthiessen (2004, p. 208-210) dividem esses processos em quatro instâncias: processos mentais de cognição, relacionados à decisão e à compreensão (avaliar, planejar, saber, decidir, estudar, achar, compreender); processos mentais de percepção, 
relacionados à observação de fenômenos (ouvir, cheirar, experimentar, sentir, ver, perceber); processos mentais emotivos, relacionados aos sentimentos (odiar, agradar, gostar, amar); e processos mentais desiderativos, relacionados aos desejos (almejar, querer, desejar).

Os participantes desse tipo de processo são o Experienciador (Senser), o participante dotado de consciência, em cuja mente o processo está-se realizando; e o Fenômeno, que é o elemento percebido/sentido/criado pelo Experienciador. Esse participante pode exercer duas funções: a de Fenômeno-Fato - macro-fenomenal e a de Fenômeno-Ato - meta-fenomenal (HALLIDAY; MATTHIESSEN, 2004, p. 203-204), sendo que o Fenômeno-Fato é uma projeção da oração, projeção do discurso por citação, que Halliday (2002, p. 185) denomina “orações de verbalização".

A projeção é uma das possibilidades de distinção entre os processos mental e material. Isso, porque somente o processo mental (com Fenômeno-Fato) pode projetar outra oração. A projeção entre orações é um fenômeno particular de dois tipos de processos: o mental e o verbal, o que os faz especiais, pois podem projetar qualquer tipo de oração (verbal, material, comportamental, relacional). Ressalte-se que, em sua forma estrutural, o Fenômeno-Ato sucede o processo mental com um grupo nominal; já o Fenômeno-Fato é introduzido pelo denominado pronome relativo "que". Observemos os trechos a seguir:

(3) "Eu (Experienciador) não quero (processo mental) isso aqui pra mim (FenômenoAto)."

(UISM, relato de David, 17a)

(4) “Aqui dentro eu (Experienciador) aprendi (processo mental) muita coisa (Fenômeno Ato)."

(CMB, relato de Isaac, $16 a)$

(5) "Pensei (processo mental) que o caminho do crime (oração projetada - Fenômeno-Fato) ia me levá a algum caminho."

(UISM, Maria Madalena,17a)

\subsubsection{PROCESSO RELACIONAL}

O Processo Relacional é o processo do "ser, ter e pertencer”. Esses processos possuem função de classificação e identificação e relacionam duas entidades no discurso, que 
constituem uma oração relacional. De acordo com Halliday (1994, p. 119), todas as línguas acomodam formas sistemáticas de realização dos processos relacionais, ou seja, estabelecem uma conexão entre as entidades. Essa relação pode ser de intensidade (Intensivo), circunstância (Circunstancial) e possessividade (Possessivo).

\section{Intensivo: $X$ é A $\longleftrightarrow$ qualificação (ser, estar)}

2. Circunstancial: X está em A

3. Possessivo: $\mathrm{X}$ tem $\mathrm{A} \longleftrightarrow$ possessão (ser de, ter, possuir, pertencer a)

$\mathrm{Na}$ perspectiva hallidayana, os processos podem ser: relacionais atributivos, em que o participante é chamado de Atributo e Portador; e relacionais identificativos, em que o participante é chamado de Identificado e Identificador ou Característica e Valor (Token e Value). Desta forma, quando a relação é de atribuição, A é um atributo de $\mathrm{X}$ e o processo relacional é classificado como Atributivo (em que o primeiro participante é um portador - a quem é atribuído algo). Por outro lado, na relação de identificação, o processo relacional é chamado Identificativo, pois A é a identidade de X. O processo relacional identificativo, conforme Thompson (2004, p. 96), tem a função de "identificar uma entidade em termos de outra”. Pode-se visualizar essas relações nos seguintes excertos:

(6) A disciplina (Portador) é (processo relacional atributivo) condição de sucesso, tanto na vida civil como militar (Atributo).

(Guia do aluno e responsável do CMB, Regime Disciplinar, 2012, p. 25)

(7) Em 1997 (Circunstância - tempo), educação e profissionalização (Portador) estiveram (processo relacional atributivo) em pauta (Circunstância - modo), por meio de articulação com a Secretaria de Estado do DF e com a Fundação Airton Senna (Circunstância - instrumento).

(Projeto Político Pedagógico das medidas Socioeducativas no Distrito Federal Internação, 2013, p. 43)

(8) “Este Colégio (Identificado) é (processo relacional) o colégio (Identificador)."

(CMB, relato de Samuel,16a)

(i) O aluno (Possuidor) tem (processo relacional possessivo) o Regimento Interno (Possuído).

(ii) A pesquisa (Portador) será (processo relacional atributivo) a respeito de disciplina (Circunstância - assunto). 


\subsubsection{PROCESSO VERBAL}

Os processos verbais representam os processos do "dizer", compostos por verbos do tipo dicendi, como declarar, perguntar, relatar, contar, dizer. Estão inseridos entre o processo mental e o relacional, configurando relações simbólicas construídas na mente e expressas em forma de linguagem (HALLIDAY; MATTHIESSEN, 2004). De acordo com Halliday (1994), "dizer" tem de ser interpretado em um sentido mais amplo, tendo em vista poder cobrir qualquer tipo de troca de significado simbólico, como em:

(i) $\mathrm{O}$ agente pede (processo verbal) para ficar em pé.

Cabe ressaltar que Eggins (2004, p. 235) conjuga desse pensamento, quando afirma que os processos verbais são processos de "ações verbais" que envolvem o verbo dizer e seus sinônimos, incluindo trocas simbólicas de significado, como em: "minha receita diz vinho tinto".

Os processos verbais, segundo Halliday (1994), também podem ser definidos como processos de simbolizar, que têm como participantes das orações verbais: o Dizente, o realizador da ação, o próprio falante; o Receptor, para quem é direcionada a mensagem, o Alvo, a entidade que é atingida pelo processo de dizer, e a Verbiagem, a mensagem propriamente dita, o que é dito e o que pode representar. Vejamos:

(9) Eu (Dizente) perguntava (processo verbal) pra ela (Receptor) todo dia (Circunstância): mãe, quem é meu pai, quem é meu pai? (Verbiagem).

(UISM, relato de David,17a)

\subsubsection{PROCESSO COMPORTAMENTAL}

Os processos comportamentais são definidos por Halliday e Matthiessen (2004, p.248) como "processos de comportamento (tipicamente humano) fisiológico e psicológico, como respirar, tossir, sorrir, sonhar e olhar.” Esses processos estão entre os processos materiais e os mentais. Contudo, Halliday (1994) observa que existem processos comportamentais como olhar, assistir, encarar, preocupar-se, que estão mais próximos de ações mentais, e outros que estão mais próximos de ações materiais, como dançar, respirar, deitar, o que acarreta uma dificuldade na compreensão de suas características. 
Observe-se que, assim como os processos mentais, os comportamentais exigem que pelo menos um de seus participantes seja uma figura animada ou personificada. São, em parte, ação, em parte, sentir (CUNHA; SOUZA, 2007). Os participantes são o Comportante, entidade que realiza a ação, tipicamente consciente e o Comportamento, que define o escopo do processo.

(i) Ele (Comportante) sorriu (processo comportamental) baixo (Circunstânciamodo).

\subsubsection{PROCESSO EXISTENCIAL}

O processo existencial concerne a algo que existe ou que acontece. Situa-se entre os processos materiais e os relacionais. Há um único participante denominado Existente (HALLIDAY; MATTHIESSEN, 2004). Como registra Silva (2013a, p.78), "além disso, os processos de natureza existencial (existir, assim como ter, no sentido de haver, inclusive o ocorrer e até mesmo dar, configuram um uso bem característico do português brasileiro)”. O segmento dialógico, em (10), configura a presença do processo ter no sentido existencial.

(10) A: “- Você é filha única?

B: - Não, tem (processo existencial) mais dois filho homem (Existente)".

(UISM, Maria Madalena, 17a)

\subsection{METAFUnÇÃo INTERPESSOAL - ORAÇÃO COMO TROCA}

A Metafunção Interpessoal se constitui na interação social entre os participantes no discurso. Há uma troca, envolvendo o falante - que oferece/ordena/pergunta/busca informações - e o(s) interlocutor(es) - que exerce(m) o papel de fornecedor(es) da informação, que aceita(m) ou rejeita(m)/cumpre(m) a ordem/responde(m). Ghio e Fernández (2008, p. 123) comentam que o significado de uma oração como troca se vincula principalmente com o sistema gramatical do Modo $(M o o d)$ e pertence à metafunção interpessoal da linguagem.

O uso da linguagem não somente espelha a estrutura social, mas também a constrói e a mantém: assim, sempre que alguém se "apropria" da linguagem ao dirigir-se a um outro socialmente superior, ambos os participantes estão 
mostrando a condição de seu status e simultaneamente reforçando o sistema social hierárquico. (THOMPSON; COLLINS, 2001, p. 137)

A linguagem, nesse sentido, tem a função de estabelecer relações entre os indivíduos. Para Halliday (1989), a interpessoalidade pode ser notada por meio de traços linguísticos nos textos, principalmente, o MODO - MOOD - (declarativo, interrogativo, imperativo) e a modalidade (o grau de comprometimento ou de afinidade com as proposições expressas no texto). O sistema de MODO "é o recurso gramatical para se realizarem movimentos interativos no diálogo" (MARTIN; MATTHIESSEN; PAINTER, 1997, p. 58). Conforme Halliday e Matthiessen (2014),

MODO é o maior sistema interpessoal da oração; ele provê os interactantes envolvidos no diálogo com os recursos para dar ou pedir uma mercadoria/produto, bem como informações ou bens e serviços - em outras palavras, com os recursos para desenvolver funções da fala (atos de fala) por meio da gramática da oração: declarações (dando informações), perguntas (pedindo informações), ofertas (dando bens e serviços), e comandos (demandando bens e serviços). (HALLIDAY; MATTHIESSEN, 2014, p. 97)

Nesse sistema, a oração se organiza em duas partes: o Modo e o Resíduo, sendo o Modo subdividido em Sujeito e Finito e o Resíduo em Predicador, Complemento e Adjunto. O Sujeito é o grupo nominal que pode ser um pronome pessoal, demonstrativo, indefinido e mesmo uma oração inteira, em casos de encaixamento. $\mathrm{O}$ operador Finito é parte do grupo verbal que expressa tempo e inclui a polaridade e a modalidade. O Predicador está sempre presente, embora, às vezes, esteja elíptico. Equivale a um verbo ou a um grupo verbal desprovidos de auxiliares. Os Complementos são, geralmente, grupos nominais que completam o sentido do verbo da oração e que teriam potencial para ser o Sujeito, entretanto não ocupam essa função na oração. Os Adjuntos são os elementos constituídos por grupos adverbiais ou sintagmas preposicionais.

Cabe ressaltar que os Adjuntos abrangem dois tipos especiais de Adjuntos Modais que podem ocorrer no Resíduo: os Adjuntos do grupo do (a) Modo e os do grupo do (b) Comentário (HALLIDAY, 1994, p. 81-84). O grupo pertencente ao Modo reporta-se às noções de polaridade, modalidade, temporalidade e modo. Já os Adjuntos do grupo Comentário exprimem a atitude do falante diante da proposição como um todo.

Do ponto de vista semântico das trocas de papéis entre os participantes no intercâmbio e na negociação de proposições (informações) e propostas (bens e serviços) que são oferecidos, aceitos ou rejeitados, cada escolha é realizada por meio de uma seleção de opções dentro do sistema de modo de uma sentença (proposição ou proposta). Sendo assim, na 
interação, o falante exerce papéis mediados pela linguagem - ele pode declarar ou perguntar, por meio de questões abertas ou fechadas, ou mesmo solicitar/oferecer serviços e bens ou informações. Halliday (1994) usa, para esses casos, o termo commodity, com o intuito de mostrar o que está sendo tratado entre emissor/receptor. Apesar de bens e serviços serem capazes de existir independentemente da linguagem, dar ou pedir informações só se realizam por meio de trocas simbólicas.

No que diz respeito à modalização ou modalidade epistêmica, existem dois tipos de possibilidades para expressar os significados: os graus de probabilidade e os graus de usualidade (frequência). Ambos podem ser expressos por verbos e adjetivos modais ou por adjuntos modais. Já a modulação ou modalidade deônica, pode realizar-se de duas formas: em termos de obrigação e em termos de disposição. Podem ser expressas por verbos modalizadores e adjuntos modais. Cabe ressaltar que tanto na modalização quanto na modulação, há graus que vão do polo positivo ao negativo, como: sempre, usualmente, às vezes, nunca.

Figura 2.3 - Diagrama da Relação de Modalidade e Polaridade

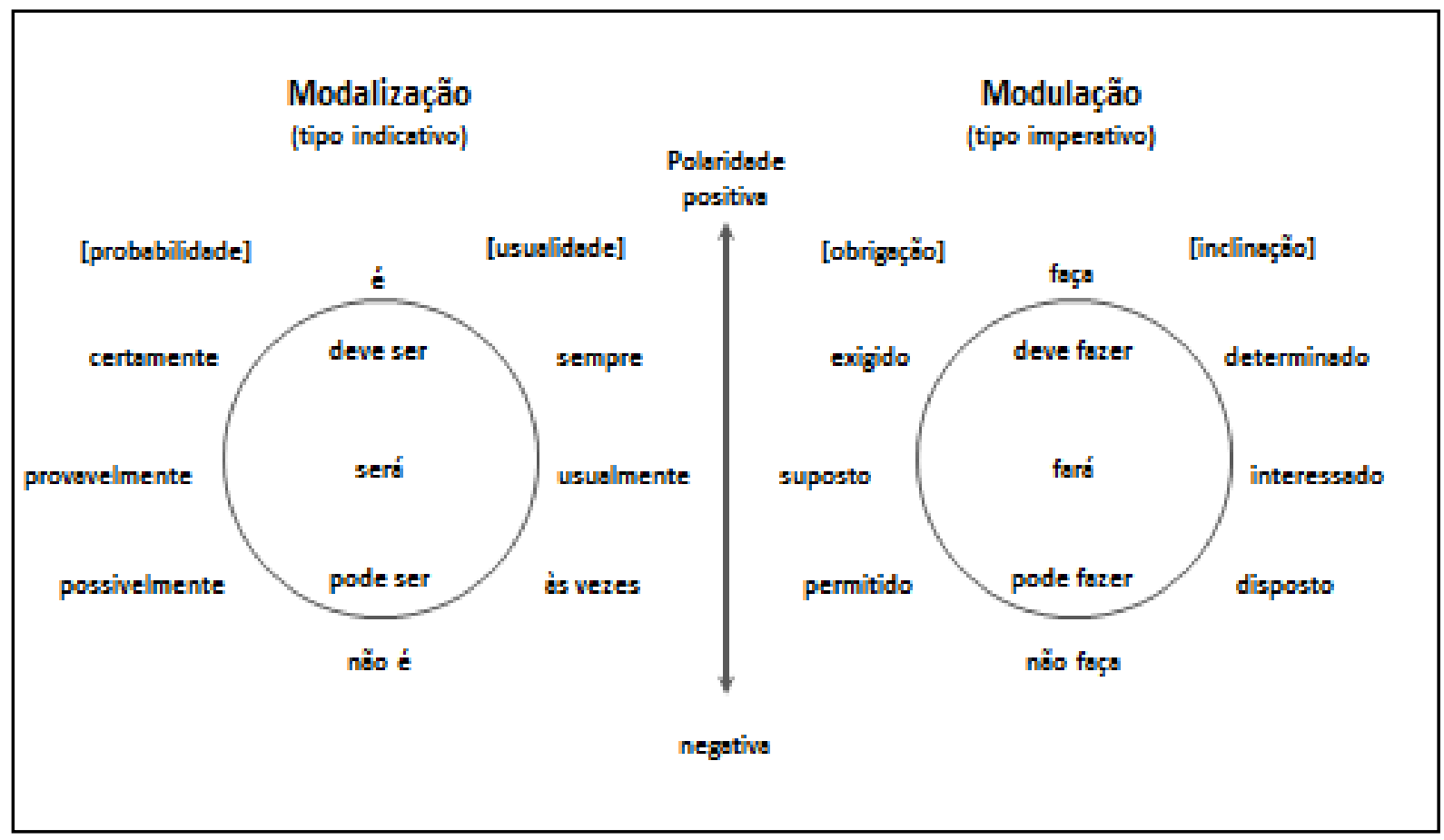

Fonte: Traduzido e adaptado a partir de Halliday e Matthiessen (2004, p. 619)

Assim, a modalidade pode situar-se em grau baixo, médio e alto de julgamento, atentando-se, porém, para a polaridade sim - não (polo positivo e polo negativo). São formas 
objetivas implícitas que podem ser categorizadas. Os três valores da modalidade distribuemse em: grau alto (certamente, sempre, necessário); grau médio: (provável, usualmente, suposto) e grau baixo (possível, às vezes, permitido). A seguir, será apresentado um fragmento do Guia do aluno e responsável do CMB para ilustrar a Metafunção Interpessoal.

(11) Os alunos não poderão se ausentar da Cia de Al durante o horário de aula, exceto casos emergenciais, após análise do Cmt de Cia ou do Sargento.

(Guia do aluno e responsável do CMB, p. 11, 2012)

\begin{tabular}{|c|c|c|c|}
\hline Os alunos & não poderão & se ausentar & $\begin{array}{c}\text { da Cia de Al durante o horário de aula, exceto } \\
\text { casos emergenciais, após análise do Cmt de Cia } \\
\text { ou do Sargento. }\end{array}$ \\
\hline \multirow{2}{*}{ sujeito } & $\begin{array}{c}\text { Modalidade } \\
\text { deôntica }\end{array}$ & \multirow{2}{*}{ predicador } & \multirow{2}{*}{ adjunto } \\
\hline & finito & & \\
\hline \multicolumn{2}{|c|}{ Modo } & \multicolumn{2}{|r|}{ Resíduo } \\
\hline
\end{tabular}

Como forma de estender o modelo de significado interpessoal, Martin e White (2005) apresentaram a proposta do Sistema de Avaliatividade, ferramenta da qual faço uso para a análise do corpus no capítulo 5. Vejamos.

\subsection{MetAfunÇão TeXTUAL - ORAÇão COMO MENSAGEM}

Para Halliday, a língua se organiza em torno de redes relativamente independentes de escolhas e essas redes representam três funções básicas da linguagem: a metafunção ideacional (representação de experiências e do mundo - interior e exterior); a metafunção interpessoal (interação dos participantes no discurso); e a metafunção textual (construção e organização do texto, de forma que esse texto se ligue a contextos situacionais).

$\mathrm{Na}$ metafunção textual, devem ser considerados e averiguados aspectos semânticos, gramaticais, estruturais, inseridos no texto em conformidade ao fator funcional, uma vez que a seleção de estruturas textuais relaciona-se a contextos sociais de interação. Essa metafunção é a função que permite discernir e organizar uma mensagem na oração. Tem a função de estruturar os significados ideacional e interpessoal, como uma informação organizada. Há 
dois sistemas para organizar a informação em uma mensagem: o sistema temático: Tema/Rema e o sistema de hierarquização da informação: Dado/Novo.

De acordo com Halliday (1994, p. 299), existe uma relação semântica entre a estrutura da informação e a estrutura temática. O Tema de uma sentença é indicado por vir em primeiro lugar na sentença e por funcionar como ponto de partida para a mensagem. Ademais, pode ser um participante, um processo ou uma circunstância. O Rema é o que vem após o Tema, é o desenvolvimento do tema (HALLIDAY; MATTHIESSEN, 2004).

É relevante destacar que essa noção de Tema e Rema teve a influência da Escola de Praga, entretanto não comunga totalmente dessa perspectiva, pois enquanto a Escola de Praga assume Tema como informação dada e Rema como informação nova, Halliday (1994) considera os conceitos de dado e novo e de Tema e Rema como distintos e os separa, de forma que a informação apresentada pelo falante como recuperável é o Dado. O Novo é o que não pode ser recuperado pelo ouvinte. Nessa visão, Tema nem sempre coincide com o dado.

(12) As medidas socioeducativas (Tema) possuem uma dimensão jurídico-sancionatória e uma dimensão substancial ético-pedagógica (Rema).

(Projeto Político Pedagógico das medidas Socioeducativas no Distrito Federal Internação, 2013)

(13) A disciplina (Dado) é condição de sucesso, tanto na vida civil como militar (Novo).

(Guia do aluno e responsável do CMB, 2012, p.25)

\subsection{O Sistema de Avaliatividade}

A Teoria da Avaliatividade foi desenvolvida a partir da Linguística SistêmicoFuncional (LSF), com base nos aspectos avaliativos inerentes à linguagem. Dessa forma, linguistas sistêmico-funcionais da Escola de Sydney desenvolveram estudos voltados para a análise das avaliações, o que resultou, posteriormente, em pesquisas sobre avaliação como recurso interpessoal para expressar a avaliação no discurso em contextos diversificados. Criou-se, então, a Appraisal Theory, denominada como Sistema de Avaliatividade (MARTIN; WHITE, 2005), o qual envolve o estudo dos significados interpessoais, sentimentos e atitudes dos participantes do discurso. Esse sistema é parte de uma perspectiva de análise de discurso no bojo da LSF composta, de acordo Martin e Rose (2007), por seis sistemas discursivos: 
Avaliatividade, Negociação, Ideação, Conjunção, Identificação e Periodicidade. Cabe destacar que neste trabalho vou-me ater à Avaliatividade.

A Avaliatividade concerne, segundo Martin e Rose (2007, p. 25), aos tipos de atitudes que são negociadas em um texto, à força dos sentimentos envolvidos e ao modo como tais valores aparecem e são alinhados. Nesse sentido, a Avaliatividade envolve a semântica do discurso, pois possibilita relacionar as formas como os falantes expressam suas posições, seus comportamentos e suas atitudes perante o que falam e por meio da interação entre os participantes do discurso. Para tanto, tal instrumento de Avaliatividade torna-se primordial para a presente pesquisa, já que, do ponto de vista de uma análise calcada na LSF, esse recurso insere-se no sistema interpessoal e se refere à forma como os valores emergem e são dispostos no texto.

O Sistema de Avaliatividade localiza-se no estrato semântico-discursivo que envolve um sistema de significados interpessoais, ou seja, um recurso semântico-discursivo usado para negociar emoções, julgamentos e avaliações (MARTIN, 2000). Esse sistema, conforme apontam Martin e Rose (2007), é um dos principais recursos semântico-discursivos para a realização dos significados interpessoais em relação às avaliações de coisas, ao comportamento das pessoas e seus sentimentos.

Destaca-se, a seguir, a categorização semântica do sistema de Avaliatividade de acordo com o proposto pelos estudos da Escola de Sidney.

\section{Esquema 2.1 - Sistema de Avaliatividade}

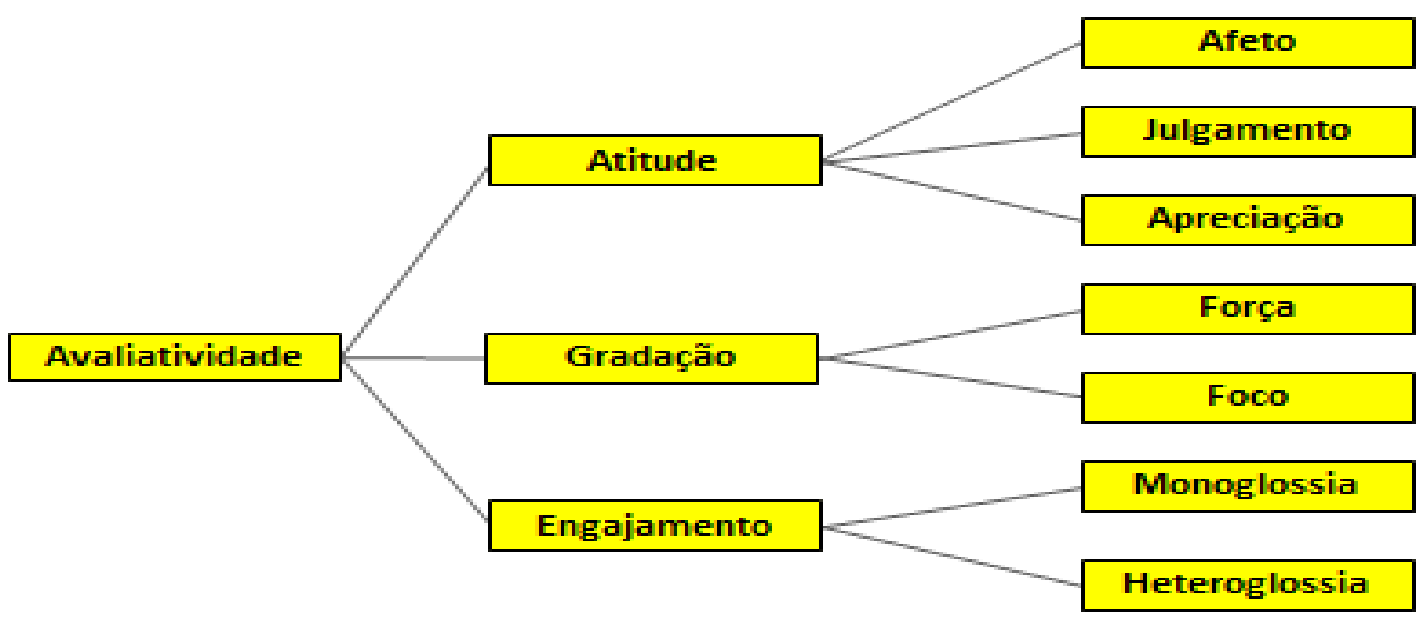

Fonte: adaptado de Martin e Rose (2007, p. 48) 
De acordo com o Esquema 2.4, pode-se observar o Sistema de Avaliatividade. Esse sistema realiza-se em três subsistemas: atitude, a gradação e o engajamento. A atitude é expressa por três campos: pelo afeto, pelo julgamento ou pela apreciação e compreende, respectivamente, os sentimentos, julgamento de comportamentos e avaliação de objetos e situações. A gradação, conforme Martin e White (2005, p. 35), trata do fenômeno gradativo pelo qual os sentimentos são ampliados. O sistema de gradação divide-se em dois subsistemas: a força, que oferece recursos para graduar qualidades e processos e o foco, que oferece recursos para graduar categorias semânticas prototípicas que, em princípio, não podem ser graduadas. Por último, o engajamento concerne à possibilidade de o texto conter uma voz (monoglossia) ou ter mais de uma (heteroglossia).

O foco de parte das análises recairá sobre o Sistema de Avaliatividade, no subsistema Atitude, como veremos no capítulo 4. Por isso, farei uma breve exposição do subsistema Atitude, bem como de seus subtipos, que são afeto, julgamento e apreciação.

\subsubsection{Atitude}

O subsistema de Atitude envolve opinião, avaliação, emoção, comportamentos, bem como posicionamentos diante de fatos ou acontecimentos. A Atitude provê recursos para avaliar coisas, o caráter das pessoas e seus sentimentos. Conforme aponta Martin (2000), a Atitude engloba significados pelos quais textos e falantes conectam valores subjetivos ou avaliações a participantes e processos com referência a respostas emocionais ou a sistemas de valores culturalmente orientados. O domínio semântico da atitude se divide em três outros subsistemas, segundo Martin e Rose (2007, p. 26): afeto, julgamento e apreciação. O afeto (affect) concerne às emoções e aos sentimentos; o julgamento (judgement) refere-se às questões éticas, ao caráter das pessoas envolvidas no discurso; e a apreciação (appreciation) está relacionada à estética e à avaliação de coisas, instituições e fenômenos. Dessa forma, esse subsistema é responsável pela expressão linguístico-discursiva das avaliações negativas e positivas vinculadas à emoção, à ética e à estética (MARTIN; WHITE, 2005). Abaixo, podese observar as relações como se pode observar no Esquema abaixo: 


\section{Esquema 2.2 - Correspondência dos Subsistemas de Atitude}
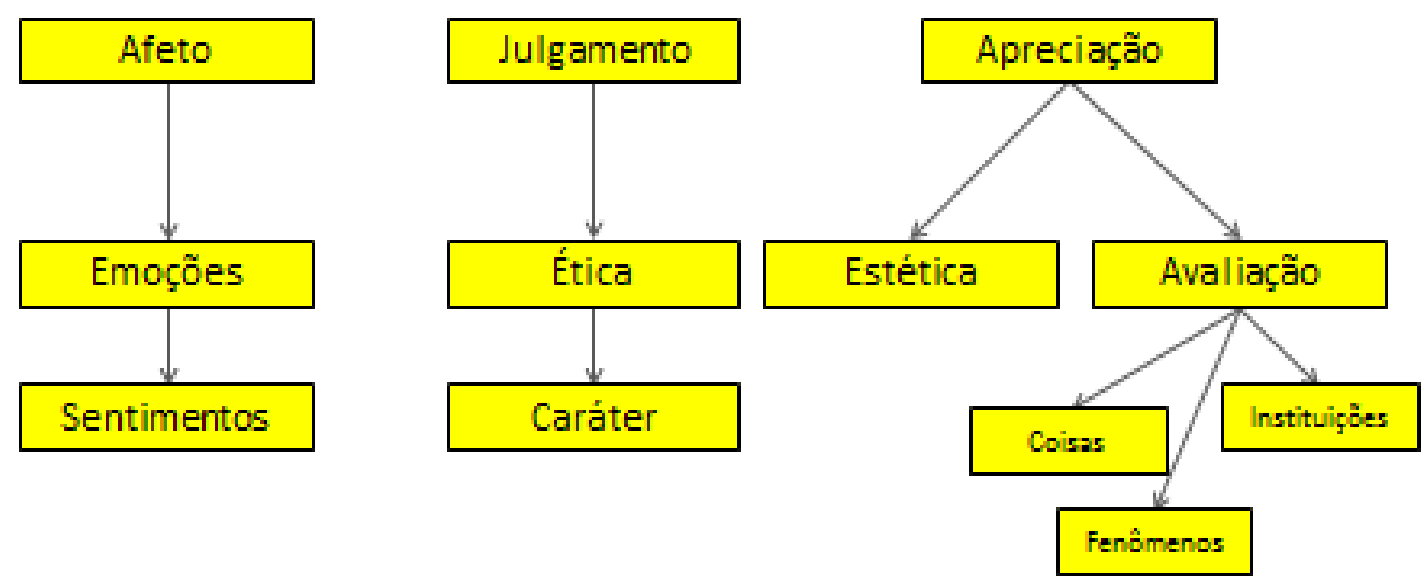

Fonte: Adaptado de Martin e White (2005), com acréscimos feitos pela autora

O Esquema 2.5 representa correlação do subsistema de Atitude, desdobrado em afeto, julgamento e apreciação, com elementos semântico-discursivos do discurso. Ressalte-se que esses elementos podem ocorrer nos polos positivo ou negativo, os quais podem ser expressos de forma direta, realizada por grupos nominais que expressem afeto, ou implícita, inferida baseada na descrição do comportamento das pessoas, o que inclui a realização de processos (MARTIN; ROSE, 2007, p. 26). A seguir, será explicitado o subsistema referente à Atitude, pois as subcategorias afeto, julgamento e apreciação foram encontradas nos textos orais e escritos de adolescentes do CMB e da UISM.

\subsubsection{Afeto}

A subcategoria Afeto envolve, segundo Martin (2000, p. 148), um recurso semântico para construir emoções das pessoas, que podem ser compreendidas como bons (afetos positivos) ou maus (afetos negativos) sentimentos, de acordo com a manifestação implícita ou explícita (MARTIN; ROSE, 2007, p. 25-26). Martin e White (2005, p. 49), dividem as emoções em três partes:

In/Felicidade: emoções relacionadas ao coração: triste/feliz.

In/Segurança: emoções relacionadas ao bem-estar social: aflito/ confiante.

In/Satisfação: emoções relacionadas aos objetivos realizados: indignado/curioso. 
$\mathrm{Na}$ lexicogramática, os afetos podem aparecer em diferentes esferas, tais como nas qualidades, nos processos e nos comentários. Sendo assim, o afeto pode ser realizado por categorias gramaticais em epíteto, atributo, processos verbais, principalmente mentais e comportamentais, e adjuntos circunstanciais.

\subsubsection{Julgamento}

O julgamento, conforme Martin e White (2005, p. 42), é responsável por tratar de "atitudes perante comportamentos que admiramos ou criticamos, aprovamos ou condenamos". O julgamento refere-se às questões de "ética" e a avaliações concernentes a condutas morais e normas de comportamento, as quais configuram um tipo de institucionalização dos sentimentos correspondente a prescrições sociais a respeito do que deveria e o que não deveria ser feito. (MARTIN; ROSE, 2007, p. 32).

O julgamento pode estar vinculado a um sistema de estima ou de sanção social. No sistema de estima social, observa-se a conformidade de comportamento de uma pessoa como aceitável (normalidade) ou recomendável, bem como por ter habilidade ou capacidade para desempenhar alguma ação ou função (capacidade) e também o quão empenhado está em fazer algo (tenacidade). Já a sanção social, envolve a aprovação (praise) ou a reprovação (condemn). O comportamento é avaliado de acordo com os critérios de veracidade (envolve o conceito de verdade e honestidade) e também quanto à correção e adequação (propriedade) ou inadequação (impropriedade) em relação às regras sociais que vigoram. O julgamento e seus subtipos apresentam-se da seguinte forma:

\section{Esquema 2.3 - Julgamento e seus subtipos}

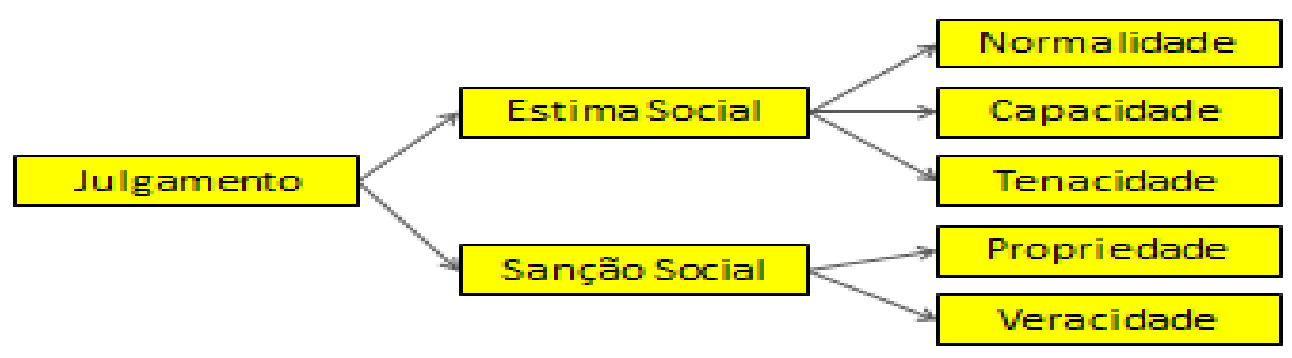


Pode-se dizer, então, que o julgamento é um recurso semântico que destaca as qualidades do falante/escritor e abarca questões avaliativas a respeito de moralidade, legalidade, capacidade, normalidade, sempre determinadas por contextos, culturas, crenças e valores. Martin (2000, p. 156) sugere que sejam feitas determinadas perguntas para facilitar a categorização do julgamento. Destarte, para descobrir se a categoria normalidade, pode-se perguntar se o comportamento da pessoa é comum ou pouco usual; para a capacidade, sugerese perguntar se o indivíduo é capaz ou competente; para tenacidade, se a pessoa é confiável; para veracidade, pode-se perguntar se o indivíduo é honesto; e, finalmente, para a propriedade, se o indivíduo é ético.

\subsubsection{Apreciação}

A apreciação, conforme Martin e White (2005, p. 43), concerne a "avaliações de fenômenos semióticos e naturais, de acordo com os modos como a eles são ou não atribuídos valores em um determinado campo". Com esse sistema, pode-se fazer uma avaliação de coisas não conscientes, físicas ou semióticas, pois, para os autores (MARTIN; WHITE, 2005, p. 56), o sistema de apreciação trata do modo como se avalia e se dá significados às coisas, aos objetos e aos fenômenos em geral.

As realizações do Sistema Apreciação podem ocorrer por itens léxico-gramaticais ou orações completas. Esse sistema está organizado em três categorias: reação, composição e valorização, como ilustra o Esquema abaixo.

\section{Esquema 2.4 - Apreciação}

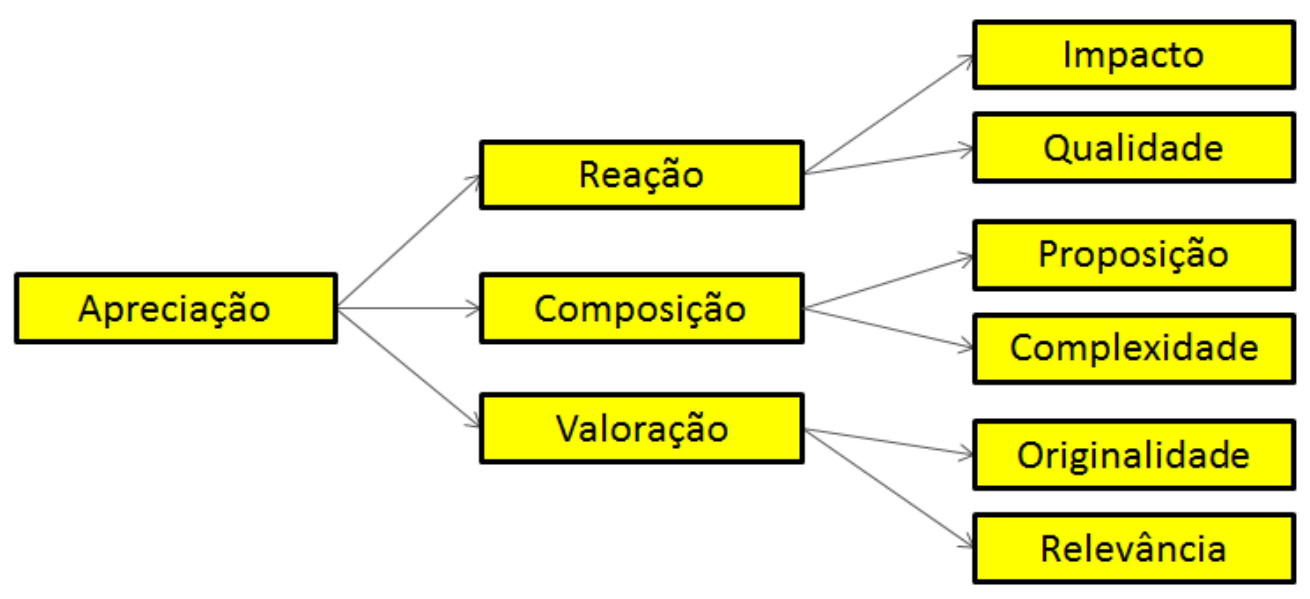


No Sistema Apreciação, os recursos de reação estão relacionados às reações que as coisas provocam nas pessoas, podendo ser consideradas em relação ao seu impacto e na forma como afetam as pessoas. Essas reações concernem a impactos, alterações e atitudes variadas. A Composição, na visão de Martin e White (2005, p. 57), envolve percepção, complexidade e equilíbrio. Essa categoria subdivide-se nas categorias de proporção, referente ao seu equilíbrio, e complexidade, categoria referente à ordem e à compreensão de algo. A Valoração refere-se ao valor atribuído às coisas ou objetos de acordo com convenções sociais, ou conforme sua originalidade em conformidade com essas mesmas convenções, dependendo de sua importância. Nessa vertente, Martin e Rose (2007) abordam a valoração como uma caracterização de avaliação presente em escolhas lexicais dos produtores do discurso. Sendo assim, a valoração caracteriza as atitudes dos participantes do discurso, por meio de elementos linguísticos que apontam seus sentimentos.

\subsubsection{Gradação}

A gradação permite graduar as avaliações no sistema de atitude, tornando-as mais fortes ou mais fracas e mais ou menos evidentes. Conforme Martin e White (2005, p. 37), a Gradação concerne ao ajuste do grau de avaliação, ou seja, o quão forte ou fraco é o sentimento. A gradação se realiza em dois eixos: o foco, que opera de acordo com questões de exatidão e a força, que está relacionada à intensidade ou à quantidade.

\section{Esquema 2.5 - Gradação}

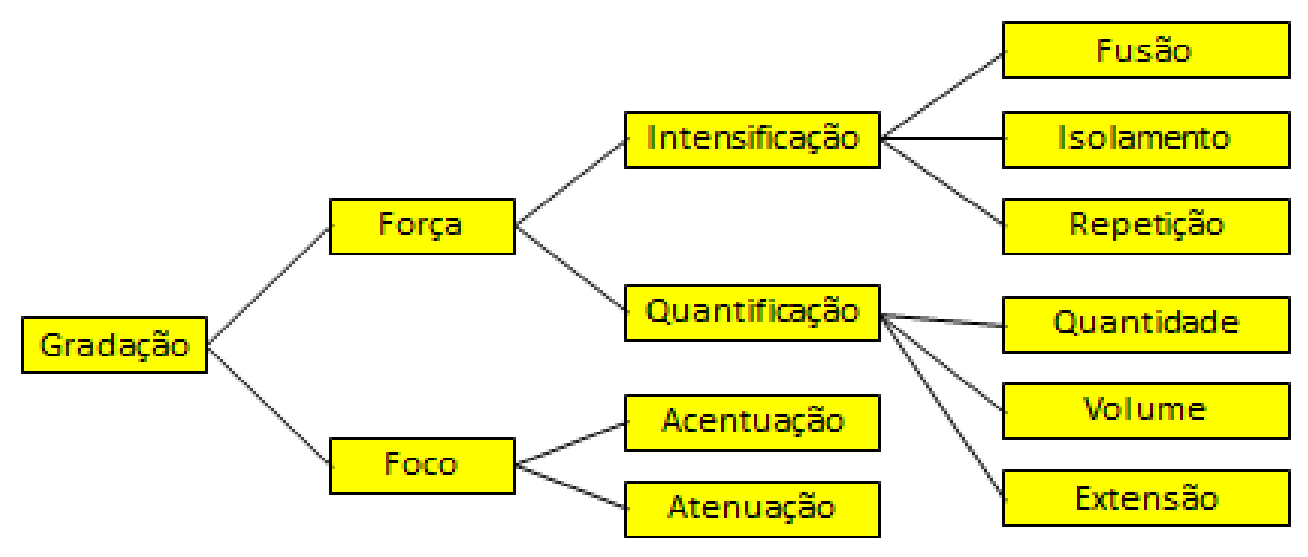

Fonte: Adaptado de Martin e White (2005) 
Segundo Martin e White (2005),

a Gradação preocupa-se com a gradabilidade. Para a Atitude, já que os recursos são inerentemente graduáveis, a Gradação consiste em ajustar o grau de uma avaliação, o quão forte ou fraco o sentimento é. Este tipo de GRADAÇÃO recebe o nome de 'força'; suas realizações incluem intensificação, morfologia comparativa e superlativa, repetição e vários aspectos grafológicos e fonológicos - juntamente ao uso do léxico intensificado_ 'odiar' para não gostar, e assim por diante (MARTIN e WHITE, 2005, p. 37).

Dessa forma, a Gradação procura situar os fenômenos em conformidade com a intensidade e suas respectivas ocorrências.

\subsubsection{Engajamento}

O Engajamento dá acesso aos recursos de posicionamento subjetivo nas avaliações no Sistema de Atitude, revelando a voz ou as vozes autorais, de onde elas partem e os significados pelos quais o falante pode se aproximar ou se distanciar dos pontos de vista lançados em sua enunciação. Dessa forma, segundo Martin e White (2005, p. 35), o "Engajamento lida com a Atitude de terceiros e a prática das vozes sobre opiniões no discurso". Esse subsistema se divide em monoglossia (uma voz) e heteroglossia (mais de uma voz).

A partir de uma ampla perspectiva da interioridade da linguagem que perpassou pela organização por meio de estratos, por variáveis do Contexto de Situação, pelas Metafunções Ideacional, Interpessoal e Textual, bem como pelo Sistema de Avaliatividade, será enfocada, a seguir, a exterioridade da linguagem, em uma perspectiva do discurso como prática social.

\subsection{DA EXTERIORIDADE DA LINGUAGEM: O DISCURSO COMO PRÁTICA SOCIAL}

A linguagem tem o relevante papel de promover a interação, a integração e a inserção das pessoas na sociedade. É fato que, cada povo, embora oriundo do mesmo gênero humano, consegue distinguir-se de seus semelhantes pela diversidade de pensamento, hábitos e modus vivendi apresentados, ou seja, pela linguagem. A linguagem, portanto, faz parte da sociedade e é um elemento inerente desta. Ela é representativa e constitui a realidade social. 
Sob essa perspectiva, é importante destacar a interação entre linguagem e sociedade. Essa visão interacional é defendida e assumida pela Análise de Discurso Crítica (ADC) ${ }^{9}$ como explicita Dias (2011, p. 227), "de modo a superar um olhar neutro sobre as trocas linguísticas e a superar uma visão estanque da estrutura da língua, de um lado, e dos sujeitos sociais, de outro". Ressalto que, como processo social, a linguagem deve envolver o discurso, porque pode ser considerada como forma de prática social.

O discurso e a estrutura social têm uma inter-relação dialética. É por meio dele que os indivíduos constroem sua própria realidade na sociedade, agem em condições históricosociais, apontam suas visões de mundo e distinguem-se nas relações de poder nas quais operam. Discurso, nesse sentido, envolve a semiose/linguagem em conexão com os demais momentos: fenômeno mental, relações sociais e mundo material.

De forma mais ampla, 'discurso'(substantivo incontável) é o uso da linguagem visto como prática social. De forma específica, 'discurso'(substantivo contável) consiste em maneiras de criar significados a partir de uma perspectiva em particular - discurso feminista, discurso ecológico, discurso (socio)educativo, presente nesta tese -, modos de falar, de ver e de pensar (FAIRCLOUGH, 1995). Os discursos materializam-se nos textos (tanto falados quanto escritos), por meio dos eventos e das práticas, o significa que as características linguísticas presentes em um texto são determinadas pelas características do(s) discurso(s) que este exemplifica (MEURER, 1997). Por isso, a partir dessas práticas, conforme Chouliaraki e Fairclough (1999), torna-se possível compreender como diversos mecanismos e suas estruturas específicas relacionam-se com os eventos e atores sociais concretos.

O discurso, como elemento da prática social, tem sua base em seu contexto. Já a prática social abarca comportamentos que envolvem convenções relativamente estáveis atuantes como parte de regras e normas que disciplinam as ações, as atividades e o comportamento humanos. Os conhecimentos linguísticos e as convenções discursivas estão inseridos em muitas dessas práticas e esse conhecimento é absorvido por meio dos eventos, como parte da vivência social. Sendo assim, o discurso é considerado um modo de ação e representação.

\footnotetext{
${ }^{9}$ Cabe ressaltar que, neste trabalho, foi adotada a tradução Análise de Discurso Crítica (ADC) de acordo com a proposta da pesquisadora Maria Izabel Magalhães, em trabalho pioneiro na Universidade de Brasília (UnB), como referência aos estudos feitos por Fairclough (1992). De acordo com Silva (2012, p. 226), é o slogan da Análise de Discurso da UnB, pois "marca a entrada do 'grupo de Brasília' no cenário dos estudos do discurso, voltados para textos e eventos em diversas práticas sociais, bem como para descrever e interpretar a linguagem no contexto sócio-histórico e político".
} 
Cada discurso age de uma forma diferente na sociedade, pois traz em si traços de ação individual e social de quem o produziu. Ademais, ele é recebido por um ser único, com suas crenças, valores, relações sociais, ou seja, com sua própria visão de mundo.

Fairclough (2001, p. 64) menciona que no discurso há efeitos constitutivos como a contribuição para a construção de identidades sociais ou posições de sujeito e dos sistemas de conhecimento e crenças, bem como a construção de relações sociais. Porém, esses efeitos constitutivos do discurso não são transparentes para a sociedade, o que acarreta, muitas vezes, uma possibilidade de mudança, por meio de indagação ou mesmo contestação, legitimada pelo uso da linguagem, a não somente textos escritos ou falados, mas também a qualquer tipo de semiose em que haja materializações de escolhas linguísticas que estejam relacionadas a processos sociais em que seus produtores estejam situados.

Na Teoria social do Discurso, proposta por Norman Fairclough $(1992,2003)$, almejase compreender, identificar ou mesmo perceber as representações que se inserem em um determinado evento e as estruturas que alicerçam as práticas. Conforme assevera o autor (2001), "a constituição discursiva da sociedade não emana de um livre jogo de ideias nas cabeças das pessoas, mas em uma prática social enraizada em estruturas sociais materiais concretas, orientando-se para elas". O discurso constitui as práticas sociais, uma vez que as práticas sociais constituem o discurso.

Cada prática é uma articulação de elementos sociais diversos dentro de uma configuração relativamente estável (FAIRCLOUGH, 1992). Dessa forma, caracterizo como discurso disciplinador, a prática que envolve elementos de ordem do discurso que costumam refletir práticas sociais reguladoras de conduta e comportamento para o cumprimento de normas e regras, com tais elementos encontrados e configurados em representações linguístico-discursivas.

Por isso, perfilha-se, neste trabalho, a vertente ao estudo situado do funcionamento da linguagem na sociedade, como a de Silva (2008), para quem a ADC

constitui uma forma de pesquisa social e, como tal, é também considerada uma prática teórica crítica, sobretudo, porque se baseia na premissa de que situações opressoras podem ser mudadas, uma vez que são criações sociais passíveis de serem transformadas socialmente. (SILVA, 2008, p. 267-268)

Tomando-se por base as palavras de Silva (2008), o presente estudo insere-se na proposta teórica da teoria Social do Discurso (FAIRCLOUGH, 2001), uma vez que enfoca os seguintes pontos: a) práticas discursivas disciplinadoras; b) de duas instituições, alinhadas em 
termos de princípios de formação disciplinar; c) com práticas sociais diferenciadas associadas a questões relacionadas ao poder e ao ethos.

A ADC constitui uma forma de pesquisa social e é uma prática teórico-crítica que, além do Marxismo Ocidental, também recebeu influências dos trabalhos de Mikhail Bakhtin (1929) e Michel Foucault (1972). Influências de Bakhtin, porque foi ele o primeiro teórico a propor princípios linguísticos ideológicos, segundo os quais a linguagem é sempre usada de forma ideológica. De Foucault, para quem a linguagem representa um importante elemento do discurso correspondente a um sistema de conhecimento que incorpora o poder. Desse modo, para Foucault, todo discurso está impregnado de poder, em maior ou menor grau, e pode servir para regular a sociedade.

Sendo assim, a ADC propõe-se a desvelar aspectos encobertos, omitidos ou contraditórios nos textos e busca pistas que possam trazer à tona ideologias, relações de hegemonia, práticas discursivas de controle e poder. Por conseguinte, posiciona-se em suas abordagens de maneira crítica, devido a seu engajamento com o social.

Essa teoria-metodológica tem uma abordagem transdisciplinar, pois dialoga e se entrelaça com diferentes disciplinas das ciências sociais. Fairclough (2001) caracteriza a ADC como transdisciplinar, porque ela não apenas se utiliza de conhecimentos de outras áreas, mas também produz conhecimentos a partir de uma interdisciplinaridade. Além disso, o autor norteia seu estudo em três aspectos principais: as relações dialéticas entre discurso e práticas sociais; o grau de entendimento e conscientização que os atores sociais têm acerca dessas relações; o papel primordial do discurso nas mudanças sociais.

Nessa concepção, busca-se, aqui, identificar, sob uma perspectiva crítica, a visão que adolescentes do Colégio Militar de Brasília têm em relação aos eventos discursivos de autoridade do ambiente em que estudam, com o propósito de compará-las com a visão dos adolescentes da Unidade de Internação de Santa Maria que vivem em situação de reclusão. Ao identificar e analisar esses discursos, procura-se tecer considerações referentes ao ethos discursivo dos entrevistados. Amossy (2011) destaca que:

Todo ato de tomar a palavra implica a construção de uma imagem de si. Para tanto, não é necessário que o locutor faça seu autorretrato, detalhe suas qualidades nem mesmo que fale explicitamente de si. Seu estilo, suas competências linguísticas e enciclopédicas, suas crenças implícitas são suficientes para construir uma representação de sua pessoa. Assim, deliberadamente ou não, o locutor efetua em seu discurso uma representação de si.(AMOSSY, 2011, p. 9) 
Quando um discurso é realizado, há nele uma representação de quem o efetua. A propósito, Fairclough (2001, p. 181) define a noção de ethos como "o comportamento total de um participante, do qual seu estilo verbal (falado ou escrito) e tom de voz fazem parte, expressa o tipo de pessoa que ela é e sinaliza sua identidade”. De acordo com o autor, são características que compõem o "eu” ou a identidade social de alguém. Neste estudo, o ethos é, também, a forma como é proferido o discurso disciplinador para os adolescentes, seja para os socioeducandos seja para os alunos dos Colégios Militares.

Cabe ressaltar que a análise e a pesquisa sociais devem levar em conta a língua, o que implica um modo produtivo de se fazer pesquisa por meio da linguagem. Nessa perspectiva, conforme registra Fairclough (2003), a língua é uma parte irredutível da vida social dialeticamente conectada a outros elementos de vida social. Para entender o uso da linguagem como prática social que, para Chouliaraki e Fairclough (1999, p. 21), são "maneiras recorrentes, situadas temporal e espacialmente, pelas quais agimos e interagimos no mundo", deve-se compreendê-la não só como um modo de ação historicamente edificado e constituído socialmente, mas também como sistemas de conhecimento, crença, modos constitutivos de identidades e relações sociais.

Vale lembrar, no entanto, que essa abordagem constitutiva do discurso é alicerçada na gramática sistêmico-funcional de Halliday (1985), que recomenda três macro-funções da linguagem: interpessoal, ideacional e textual. Fairclough, entretanto, em 1992, subdivide a macro-função interpessoal em identitária e relacional. Isso, porque o autor reforça a importância da função identitária. A identidade, segundo ele, é um aspecto discursivo relevante de mudança cultural e social, pois os modos de construção e categorização de identidades em uma dada sociedade refletem seu funcionamento referente às relações de poder, à reprodução e à mudança social (FAIRCLOUGH, 1992, 2003). Nessa função, o discurso é constitutivo de autoidentidades e de identidades coletivas. Na função ideacional, o discurso contribui para a composição de sistemas de conhecimento e crença (ideologias), por meio da representação do mundo. Já a função textual, refere-se à forma como as informações são organizadas e relacionadas no texto. Dessa maneira, são feitas escolhas sobre o modelo e a estrutura de orações que são também escolhas sobre o significado (e a construção, manutenção ou subversão) de identidades sociais, relações sociais e conhecimento e crença (FAIRCLOUGH, 1992, p. 104). 


\subsubsection{Categorias de Significados}

Em 2003, Fairclough fez uma reformulação em sua teoria e propôs uma mudança intencional das "(macro)funções" de Halliday para "categorias de significados". O intuito do autor de reformular a teoria foi fazer uma proposta para uma análise de discurso textualmente orientada, voltada para a pesquisa social científica, "passando pelas implicações de poder, ideologia e identidades sociais do mundo pós-moderno até questões de luta e conflito social" (SILVA, 2012a, p. 227). Foram sugeridas três categorias de significados: o significado acional, o significado representacional e o significado identificacional. Esses significados associam-se, respectivamente, a gêneros, discursos e estilos, haja vista serem os principais elementos das ordens do discurso e estarem relacionados a práticas sociais específicas e áreas específicas da vida social. Pode-se observar essas mudanças no Quadro abaixo:

\section{Quadro 2.1 - Recontextualização da LSF na ADC}

\begin{tabular}{|l|l|l|}
\hline LSF Halliday (1991) & ADC Fairclough (1992) & ADC Fairclough (2003) \\
\hline Função ideacional & Função ideacional & $\begin{array}{l}\text { Significado representacional } \\
\text { (discursos) }\end{array}$ \\
\hline Função interpessoal & Função identitária & $\begin{array}{l}\text { Significado Identificacional } \\
\text { (estilos) }\end{array}$ \\
\hline Função textual & Função relacional & Significado acional (gêneros) \\
\hline
\end{tabular}

Fonte: Adaptado de Resende e Ramalho (2006)

Observa-se, no Quadro 2.1, a substituição das (macro)funções da Linguística Sistêmico-Funcional na Análise de Discurso Crítica, em seus significados. Fairclough (2003) correlaciona Ação e gêneros, Representação e discursos, Identificação e estilos e, ao se apropriar das premissas da Linguística Sistêmico-Funcional, menciona que os três aspectos do significado são dialeticamente relacionados, pois podem estar conectados. Um significado pode perpassar por outro de forma articulada, por exemplo: as Representações particulares (discursos) podem desempenhar de modo sui generis Ações (gêneros) e apontar modos de Identificação (estilos). A proposição desses significados preserva a questão da 
multifuncionalidade na LSF, já que Fairclough postula a atuação simultânea dos três significados no enunciado.

\subsubsection{SIGNIFICADO ACIONAL}

O significado acional corresponde aos modos de agir por meio dos gêneros. Esse significado enfoca o texto como modo de (inter)ação em eventos sociais, o que certifica o texto como importante forma de ação social. Nessa esteira, apresento, abaixo, a visão de diferentes pesquisadores a respeito de gêneros. Para tanto, começo com Hasan (1989), depois apresento a visão de pesquisadores da Escola de Sydney e, na sequência, a proposta de Fairclough (2003) e de Marcuschi (2008). Vejamos.

Na vertente da Sistêmico-Funcional, o estudo de gêneros teve início com Hasan (1977, 1984), em continuidade com Halliday e Hasan (1989), bem como com um grupo de pesquisadores da chamada Escola de Sydney (MARTIN, 2000). A LSF enfoca a linguagem como um sistema sociossemiótico, que é regulado pelo contexto social e que constrói a realidade social por meio de estruturas léxico-gramaticais. Sendo assim, linguagem e contexto social envolvem níveis semióticos complementares em uma relação dialética.

Na vertente desse pensamento, Eggins e Martin (1996) sugerem que o contexto social concerne a um sistema estratificado que compreende o nível de registro (contexto de situação) e o nível de gênero (contexto de cultura).

Registro e gênero são dois planos de realização de uma visão semiótica social do texto, visão que sustenta que os textos não são codificações neutras de uma realidade natural, mas construções semióticas de significados construídos socialmente. (EGGINS; MARTIN, 2003, p. 203)

O texto, para os autores (2003), é visto como a codificação e construção de diferentes níveis - estratos de contextos que o evidencia. Portanto, é a realização de tipos de contexto e também a colocação em cena do que interessa aos membros de uma cultura em situações determinadas.

Para Hasan (1989, p. 55), a análise de configuração contextual de um gênero, pautada na análise das variáveis de registro, pode possibilitar a identificação de elementos de sua estrutura textual. Ela propõe que, na análise de gêneros, as variáveis que compõem o contexto de situação, ou seja, o registro (campo, relação e modo), devem ser consideradas. Essa consideração deve ser feita na medida em que a configuração contextual é entendida como o conjunto específico de valores que realizam o campo, as relações e o modo do discurso. Dessa 
forma, o campo, que é o assunto, é a atividade social (o que está acontecendo). A relação refere-se à natureza dos participantes, seus papéis, como se relacionam entre si, como agem uns sobre os outros e sobre si mesmos, enquanto o modo concerne ao canal da mensagem, à seleção da informação, à voz, aos modelos coesivos, aos recursos utilizados, sejam eles nãoverbais, verbais ou multimodais.

Por isso, partindo-se da definição dos elementos da configuração contextual de cada texto, podem-se fazer predicações a respeito das próprias estruturas textuais, sobre quais elementos da estrutura textual são obrigatórios ou opcionais, quais são recursivos ou iterativos e qual a sua sequência (HASAN, 1989, p. 56). A perspectiva de Hasan, alinhada com a da LSF, "concebe a linguagem como um sistema de significações que medeia a existência social" (MOTTA-ROTH; HEBERLE, 2005, p. 12), e essa linguagem pode ser analisada como um sistema semiótico.

O texto, conforme Halliday e Hasan (1989, p.10), pode ser um produto, isto é, um objeto de estudo completo, ou um processo, um processo contínuo de escolhas semânticas, de um constante movimento pelas cadeias de significados potenciais. Sua produção, para os autores, é condicionada pelas instituições e contextos sociais, o que faz com que o texto seja de natureza social. Ressalte-se que um dos construtos teóricos produzidos pela LSF que permitem estudar os aspectos sociais dos textos é o conceito de registro, isto é, a investigação de um texto como "uma configuração de significados que estão tipicamente associados a uma configuração situacional específica” (HALLIDAY; HASAN, 1989, p. 38).

Já o grupo da Escola de Sydney reconhece os gêneros como um processo social orientado para um propósito estruturado em etapas, visto que estão ligados à concepção de língua e contexto da Linguística Sistêmico-Funcional. Os trabalhos desse grupo de pesquisadores, concernentes a gênero, envolvem os propósitos sociais de uso da linguagem. De acordo com Muniz da Silva (2015, p. 20-21), ao longo de três décadas, em três etapas, foram criados três programas de letramentos baseados nos gêneros escolares.

$\mathrm{Na}$ primeira fase, foram desenvolvidos dois projetos: Writing Project (Projeto de Escrita) e Language as Social Power (Linguagem como Poder Social), ambos com fundamentos na perspectiva teórica da LSF para a prática em sala de aula, direcionados a crianças indígenas na Austrália. Na segunda fase, foi desenvolvido o projeto Write it Right (Escreva Certo) no qual foram descritos os gêneros que os estudantes precisavam aprender para ler e escrever. A terceira fase, o projeto Reading to Learn (Ler para Aprender), está, atualmente, em desenvolvimento. Esse programa objetiva o preparo dos estudantes para ler e escrever autonomamente todos os textos previstos no currículo escolar. Os gêneros, nessa 
perspectiva, podem se relacionar conforme o foco recaia sobre entidades e atividades, indivíduo e participantes genéricos, relato e eventos explicativos, explanação e argumentação, entre outros e são agrupados por família de acordo com os propósitos sociais mais gerais e o foco de ensino da escrita. Então, podem ser encontradas as famílias de gêneros, com fins de engajar (gêneros estórias que envolvem o conto, anedotas), de informar (gêneros factuais ou informativos, concernentes a explanações, relatos e procedimentos) e de avaliar (gêneros argumentativos que se referem a exposições e discussões).

Em uma visão um pouco diferenciada, Fairclough (2003) sugere que os gêneros correspondem a uma maneira socialmente ratificada de usar a língua em um tipo particular de atividade social. Ademais, como formas de interação, constituem tipos particulares de relações sociais. Isso é explicado porque, ao se analisar um texto, questiona-se a respeito de sua contribuição para ações e eventos sociais. O texto, desse modo, adota um caráter interdiscursivo (mistura particular de gêneros, discursos e estilos) como realizado na semântica, na gramática e no léxico, características do texto em vários níveis de organização textual. Segundo o autor, os textos podem combinar diferentes gêneros em várias formas: misturando-os ou os tornando híbridos, combinando-os em "formatos" e hierarquizando-os em gêneros principais e sub-gêneros. Os gêneros, para ele, são categorizados em: a) Prégênero: deve-se usar para uma abstração maior das categorias, como as narrativas de conversação - narração, argumentação. b) Gênero desencaixado: deve-se usar para algo menos abstrato, nesse caso, as entrevistas - entrevista. c) Gênero estabilizado ou situado: deve-se usar para gêneros específicos de uma rede de práticas específicas - entrevista etnográfica, regimentos, leis. Salienta-se que, para Fairclough (2003), os gêneros são realizados por meio de significados acionais, representacionais e identificacionais, o que se justifica pelo fato de o discurso ser uma prática social e um elemento da vida social, o qual se manifesta por meio de ações, representações e identificações.

Fairclough (2003) menciona a importância de se encontrar um padrão na análise de textos e interação, mas alerta que nem sempre eles são organizados em termos de uma estrutura genérica clara, já que, com tantas transformações sociais, os diversos gêneros, assim como as formas de ação e de interação, transformam-se. Essa transformação, então, contribui para que novos gêneros surjam, até mesmo pela combinação de gêneros já existentes.

Já Marcuschi (2008, p. 161), linguista brasileiro, define gêneros como "atividades discursivas socialmente estabilizadas que se prestam aos mais variados tipos de controle social e até mesmo ao exercício de poder." São, portanto, formas de inserção, ação e controle social. O linguista concebe essa ideia porque, segundo ele, desde a concepção de seres 
humanos como seres sociais, esses se encontram envolvidos em uma "máquina sociodiscursiva" que tem como um dos instrumentos mais poderosos os gêneros textuais (MARCUSCHI, 2005). É importante notar que, para o autor, gênero é uma atividade social particular e em funcionamento da língua em ações discursivas fixadas em textos, mas não em um formato específico e fixo de texto. Os gêneros textuais, para Marcuschi, são dinâmicos, de complexidade variável e, por serem sócio-históricos e variáveis, não há como fazer uma lista fechada, o que dificulta ainda mais sua classificação. Entretanto, de seu domínio e manipulação depende boa parte da forma da inserção social e do poder social. Desse modo, a comunicação diária está pautada em algum gênero, o que explica ser a educação linguística e a social, a partir dos primeiros anos de vida, orientadas para a produção linguística de acordo com as necessidades.

Porém, Marcuschi (2005) faz uma observação a respeito das categorizações feitas por Fairclough de pré-gênero, gênero desencaixado e gênero situado. Ele atesta que, por serem os gêneros plásticos e muitas vezes híbridos, é difícil categorizá-los. Por isso, uma forma de distingui-los é determinar parâmetros com critérios, tais como: formato, natureza do tema, propósitos ou objetivos, inserção cultural, domínio discursivo, domínio institucional.

Cabe destacar que ambos os autores têm em comum a relação existente entre discurso e ação social, pois a ação social envolve o uso do gênero. Há, portanto, sistemas de valores inerentes imbricados em práticas expressas por meio de gêneros discursivos.

Norteio-me, nesta tese, pela proposta de gêneros de Fairclough (2003), para quem os gêneros são aspectos discursivos das formas humanas de ação e interação em eventos sociais (FAIRCLOUGH, 2003, p. 65) e faço uso da cadeia de gênero e de gêneros individuais em um texto particular.

\subsubsection{SIGNIFICADO REPRESENTACIONAL}

O segundo elemento textual, o significado representacional, está associado à representação de aspectos do mundo - físico, mental e social - em textos. No que tange aos significados representacionais, podem ser examinados quais os elementos dos eventos sociais são incluídos nas representações e quais são excluídos (FAIRCLOUGH, 2003, p. 135-136). Esses eventos sociais envolvem diversos elementos, como as formas de atividade, pessoas (com suas crenças/desejos/valores/histórias), relações sociais e formas institucionais, objetos, meios (tecnologias), tempo e lugar, linguagem (e outros tipos de semioses). Cabe notar que 
um mesmo aspecto de mundo pode ser representado em diferentes discursos. Ademais, o significado relaciona-se ao discurso, mais especificamente, ao discurso como representação.

\subsubsection{SIGNIFICADO IDENTIFICACIONAL}

Por último, há o significado identificacional, que enfatiza a construção e a negociação de identidades no discurso e que está relacionado ao conceito de Estilo. Os estilos, segundo Fairclough (2003), compõem aspectos discursivos de identidade. Para o autor (2003, p. 159), “à medida que o processo de identificação envolve os efeitos constitutivos do discurso, deve ser considerado um processo dialético em que os discursos são inculcados em identidades”. Assim, os significados identificacionais construídos no estilo textual pressupõem os significados representacionais. Esse significado está interligado a estilos, ou seja, aos modos de ser, como as pessoas se identificam e como são identificadas pelos outros e também pelas identidades.

Ressalte-se que Fairclough (2003) associa os três aspectos do significado a três dos quatro grandes eixos da obra de Foucault (1994): o eixo do poder, o eixo do saber e o eixo da ética, como pode ser visto no Esquema 2.6 abaixo:

\section{Esquema 2.6 - Correlação dos três grandes eixos de Foucault e os três aspectos de significado de Fairclough}

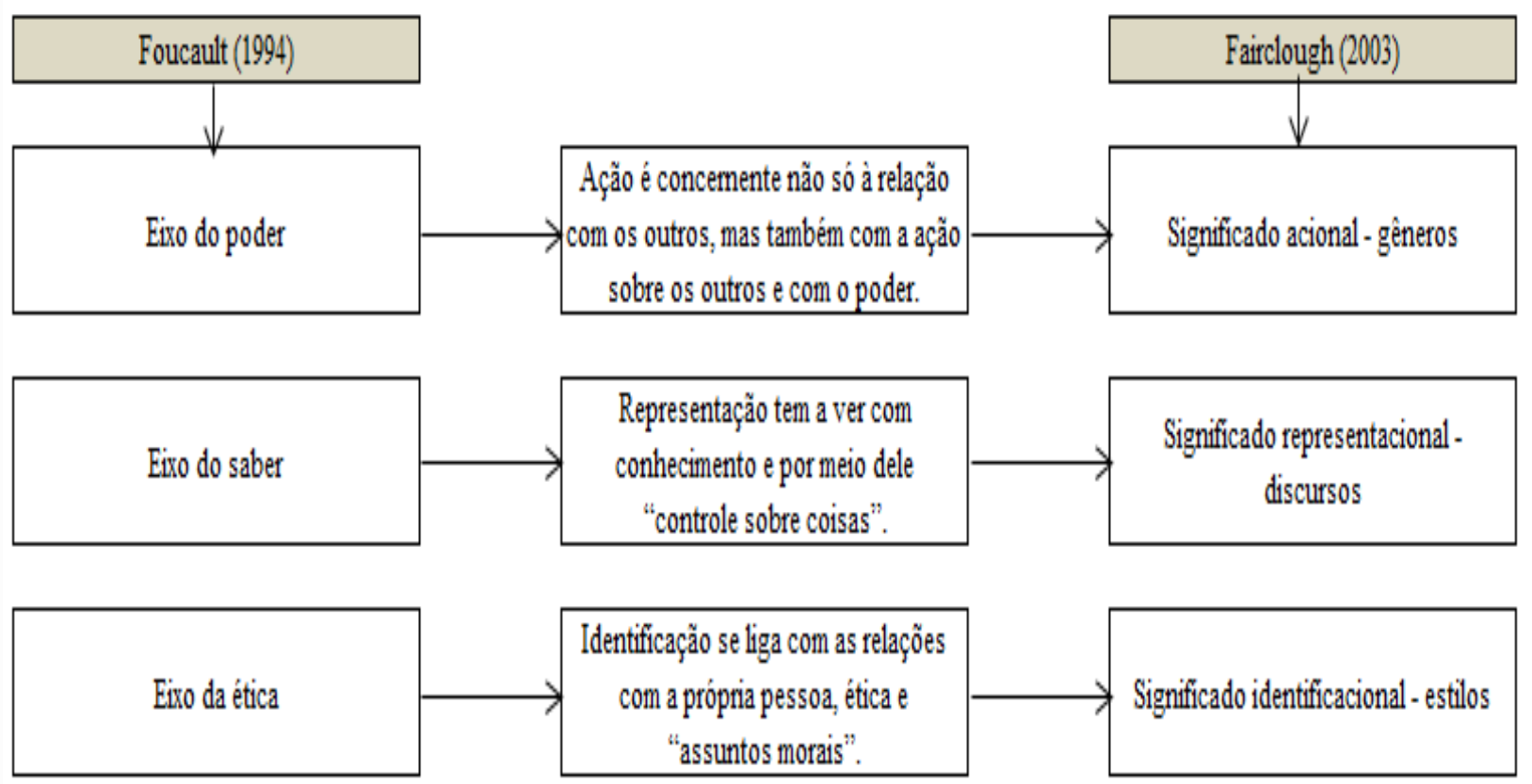

Fonte: elaborado pela autora 
No Esquema 2.6, pode-se visualizar a associação, sugerida por Fairclough (2003), dos três aspectos do significado e dos três eixos de Foucault. O eixo do poder relaciona-se com o significado acional; dessa forma, a Ação envolve não só a relação com os outros, mas também com a ação sobre os outros e com o poder. Por isso, entende-se que gêneros são modos de agir (ação) e de relacionar-se discursivamente em práticas sociais, ou seja, são as relações com os outros, sobre os outros e relações de poder. O eixo do saber vincula-se ao significado representacional; isso, porque Representação corresponde a discursos e formas particulares de representar o mundo, assim como "o controle sobre as coisas" e as relações com o conhecimento. O eixo da ética relaciona-se com o significado identificacional, na medida em que Identificação se liga às relações com a própria pessoa, como sujeitos morais. Consequentemente, as relações consigo mesmo as formas de identificar a si mesmo implicam identidades pessoais ou sociais e ética, ou seja, estilos.

A correlação dos Significados de Fairclough (2003) e dos Eixos de Foucault (1994), neste trabalho, pode ser ilustrada como: Eixo do poder - Significado acional: refere-se à parte documental; Eixo do saber - Significado representacional: concerne à maneira de como é feito o controle sobre as coisas; Eixo da ética - Significado identificacional: está associado às entrevistas feitas com adolescentes e jovens.

\subsubsection{Discursos disciplinadores: o poder disciplinador como prática social}

Interessa-nos, aqui, discutir o discurso disciplinador. Esse discurso envolve os elementos da ordem do discurso inseridos na prática social a qual, para Chouliaraki e Fairclough (1999, p. 21), corresponde a "maneiras recorrentes, situadas temporal e espacialmente, pelas quais agimos e interagimos no mundo”. Nesse diapasão, a manifestação da linguagem como discurso ocorre nas práticas sociais, o que acarreta, portanto, a impossibilidade de se desvincular os discursos disciplinadores de questões referentes a poder, ideologia e prática social.

Note-se que, apesar de supostamente se referir à mesma condição disciplinar, esse discurso é representado de maneiras diferentes e particulares. Silva (2012, p. 28) comenta que “em termos de potencialidade, pode haver em um texto diversos níveis de significados, ou seja, além de um sentido explícito, é possível encontrar-se toda uma gama de sentidos implícitos, ligados à intencionalidade de quem o escreveu".

No aspecto semântico, há definições variadas para o vocábulo “disciplinador". Guimarães (2007, p. 77) lembra que "uma semântica não pode deixar de tomar como 
elemento fundamental de suas considerações e análises a referência, ou seja, relação de palavras com algo que está fora delas". Partindo dessa assertiva, o autor acrescenta que "só é possível pensar na relação entre uma palavra e o que ocorre em virtude da relação de uma palavra a outra palavra”. Conforme sugerem Martin e Rose (2007, p. 74), "numa perspectiva gramatical, a oração é uma estrutura de palavras e grupo de palavras, mas numa estrutura semântica, a oração constrói uma atividade envolvendo pessoas e coisas". Sendo assim, a vinculação entre a significação e a relação que cada palavra pode estabelecer com outra palavra são relevantes dentro do texto. Por isso, é necessário apontar o significado da palavra "disciplinador" que, segundo o dicionário Aurélio Buarque, refere-se a "o que ou aquele que faz manter a disciplina”. Disciplinador, então, refere-se à disciplina.

Como lembra Correia (2014, p. 7), existem dois tipos de disciplina: a exógena e a endógena. A disciplina exógena, para o autor, ocorre quando a escola se empenha para estabelecer parâmetros comportamentais nos alunos, ensinando, por meio de gestores do ensino, os valores institucionais e a forma de respeitá-los. Consequentemente, esse tipo de disciplina é fruto da ação disciplinar externa, por ação de alguém ou por regramento.

No contexto desta pesquisa, além do ambiente escolar, essa forma de disciplina pode se adequar também às Unidades de Internação. Isso denota que as normas de comportamento dos socioeducandos, dentro das Unidades de Internação, tais como andar sempre em fila e com as mãos para trás, não brigar, não desacatar servidor(a), policial e professor(a) estabelecem um padrão específico de comportamento dentro dessas instituições.

Por outro lado, a disciplina endógena é um modelo de comportamento manifestado de forma espontânea pelo adolescente, quando se observa a internalização “dos valores institucionais e a forte identidade com o regramento imposto, a ponto de haver a correta interpretação de procedimentos" (CORREIA, 2014). Esse conceito disciplinar, portanto, refere-se ao indivíduo que assimilou as regras impostas, manifestando-se como competência pessoal de dentro para fora. Nesse caso, um fator de suma importância é a autodisciplina, isto é, a disciplina exercida pelo próprio ser, seja no respeito a seus valores e a dos outros, nos princípios éticos, na saúde (alimentação, higiene), no estudo, no trabalho.

Ressalte-se que disciplina, autoridade e autoritarismo são, às vezes, erroneamente associados. Guillot (2008, p. 176) esclarece que "é a autoridade que dá sentido à disciplina, não é a disciplina que faz a autoridade". Resulta que a autoridade, em instituições, ou no ambiente familiar, necessita recorrer a procedimentos que garantam a disciplina. Já o autoritarismo concerne a posturas e atitudes extremas do exercício de poder que, conforme 
Sant'Anna (2010, p. 11), "raramente conduzem ao equilíbrio", pois o respeito, a justiça e a ética tornam-se profundamente comprometidos.

Pode ser acoplado, nesse caso, o discurso aos significados e aos sentidos referentes à disciplina e a disciplinador, visto que cada discurso age de uma forma diferente na sociedade, pois nele estão inseridos traços de ação individual e social de quem o produz. Ademais, ele é recebido por um ser único, com suas crenças, valores, relações sociais, isto é, com sua própria visão de mundo. Por isso, o significado faz parte de determinado contexto e de determinada cultura.

Para Fairclough (2003, p. 28), ordens do discurso são configurações particulares e modos relativamente estáveis e duráveis de agir (gêneros que são relacionados à metafunção textual e a significados textuais acionais), de representar (discursos que são relacionados à metafunção ideacional e a significados textuais representacionais) e de ser (estilos que são relacionados à metafunção interpessoal e a significados textuais identitários). Dessa forma, são elementos da ordem do social e da ordem do cultural em todos os níveis: nas estruturas sociais, nas práticas sociais e nos eventos sociais. Ressalte-se que uma ordem de discurso envolve uma rede de práticas sociais no aspecto linguístico, ou seja, da língua.

Como mencionado, agir concerne à relação com os outros, sobre eles e com o poder; representar refere-se à representação; e ser coaduna-se com identidade. De acordo com Fairclough (2006, p. 31), os momentos discursivos ou semióticos são exemplos de ordem do discurso de uma instituição, dentro da qual se pode diferenciar discursos, gêneros e estilos característicos a cada uma. Nessa vertente, Revel (2005, p. 37) lembra que, para Foucault, a ordem do discurso de um período particular possui uma função normativa reguladora e coloca em funcionamento mecanismos de organização do real por meio de produção de saberes, de estratégias e de práticas.

A ADC, na visão fairclougheana (1999, p. 16), situa-se entre a Ciência Social Crítica e a Linguística Sistêmico-Funcional. Essa característica faz com que se torne uma estrutura analítica, teórico-metodológica, capaz de explicar o discurso e sua relação com o poder e a ideologia. Silva (2007, p. 9) lembra que a ideologia constitui um aspecto relevante para o estabelecimento e a manutenção das desigualdades nas relações de poder. Já o poder concerne às relações de diferença nas estruturas sociais. A linguagem, nesse sentido, expressa as relações de poder, bem como o envolvimento em que o poder é desafiado. Assim, o poder não é sinalizado somente por formas gramaticais em um texto, mas também pelo controle exercido em situações sociais específicas por meio de gêneros. 
Cabe ressaltar que tanto na abordagem de Fairclough (1992, 2001, 2003, 2010) quanto na de Halliday $(1985,1994)$ existe a relação entre linguagem e identidade. Além disso, desvela-se como é distribuído o poder na sociedade. Nessa tangente, evidencia-se o quão importantes são as instituições na constituição de identidades, as quais são moldadas em um processo sócio-histórico pelas relações de poder que envolvem as práticas discursivas em contextos específicos.

No sentido ideológico do discurso, ao se analisar as relações de poder, o discurso disciplinador remete a uma relação assimétrica, o que evoca o pensamento de Thompson (2011, p. 76) de que sentidos ideológicos servem para "estabelecer e sustentar relações de dominação", o que acarreta a existência de modos de ação da ideologia que naturalizam relações desiguais. Dentre essas relações desiguais, destacam-se as de gênero, as de grupos étnicos, as relações entre os indivíduos e o estado, as de estado-nação e as de blocos de estados-nação. Nesse viés, a Análise de Discurso Crítica acredita na relação dialética entre discurso e sociedade e considera que, com a mudança discursiva, é possível promover a mudança social.

Thompson (2011) compreende ideologia como o sentido a serviço da dominação. Por isso, o sentido a que o autor se refere é motivado pelas formas simbólicas que estão inseridas nos contextos sociais e que circulam no mundo social. Conforme Thompson (2011), formas simbólicas são:

um amplo espectro de ações e falas, imagens e textos, que são produzidos por sujeitos e reconhecidos por eles e outros como construtos significativos. Falas linguísticas e expressões, sejam elas faladas ou escritas, são cruciais a esse respeito. Mas formas simbólicas podem também ser não linguísticas em sua natureza (por exemplo, uma imagem visual ou um construto que combina imagens e palavras). (THOMPSON, 2011, p. 79).

Assinala Thompson (2011) que uma situação pode ser descrita como de dominação quando relações de poder são sistematicamente assimétricas, ou seja, "quando grupos particulares de agentes possuem poder de uma maneira permanente e, em grau significativo, permanecendo inacessível a outros agentes, ou a grupos de agentes, independentemente da base sobre a qual tal exclusão é levada a efeito" (THOMPSON, 2011, p. 80). Partindo dessa premissa, uma forma simbólica parece ser ideológica quando, em um contexto sócio-histórico determinado, estabelece e sustenta relações de dominação. Por essa razão, é necessário que sejam contemplados os contextos sócio-históricos específicos nos quais essa forma simbólica é produzida, transmitida e recebida. No caso dos Colégios 
Militares, a forma simbólica concerne a uma questão hierárquica, na qual a noção de respeito torna-se imprescindível para o estabelecimento da visão de poder e subordinação. Há uma relação de quem comanda e de quem é comandado. Já nas Unidades de Internação, essa forma simbólica parece ser remetida à punição que decorre do descumprimento das normas e das recomendações afixadas em medidas socioeducativas. A relação também é de quem comanda e de quem é comandado, de quem manda e de quem obedece à determinada ordem.

Sugere Thompson (2011, p.81-82) cinco modos pelos quais a ideologia pode operar: legitimação, dissimulação, unificação, fragmentação e reificação. Ressalte-se que, segundo o autor (2011, p. 82), esses cinco modos não são as únicas maneiras de a ideologia operar. Esses modos, porém, podem operar independentemente um do outro ou podem sobrepor-se e reforçar-se mutuamente, imbricando-se. A seguir, no Esquema 2.9, serão elencados os cinco modos propostos por Thompson. Apreciemos.

\section{Esquema 2.7 - Modos operacionais da ideologia}

Modos Gerais

Legitimação: as formas Simbólicas são representadas como justas e dignas de apoio, isto é, como legítimas.

\author{
Algumas Estratégias Típicas de \\ Construção Simbólica
}

Racionalização: cadeia de argumentos racionais que justificam as relações, tendo como objetivo a obtenção de apoio e persuasão.

Universalização: interesses de alguns são apresentados como interesses de todos.

Narrativização: o presente é tratado como parte de tradições eternas, que são narradas com o objetivo de mantê-las. 
Dissimulação: as formas Simbólicas são representadas de modos que desviam a atenção. Ocultação, negação ou ofuscação de processos sociais existentes.

Unificação: construção de Identidade coletiva, independentemente das diferenças individuais e sociais.

Fragmentação: segmentação de grupos ou indivíduos que possam significar ameaça aos grupos detentores do poder.
-Deslocamento: transferência de sentidos, conotações positivas ou negativas, de pessoa ou objeto a outro (a).

Eufemização: ações, instituições ou relações sociais são referidas de forma a suavizar suas características de valoração mais positiva.

Tropo: uso figurativo das formas simbólicas.

$>$ Sinédoque: tropo caracterizado pelo uso do todo pela parte, do plural pelo singular, do gênero da espécie, ou vice-versa.

$>$ Metonímia: tropo caracterizado pelo uso de atributo ou característica de algo para designar a própria coisa.

$>$ Metáfora: tropo que consiste na aplicação de termo ou frase a outro, de âmbito semântico distinto.

Estardantização (Padronização): as formas simbólicas são adaptadas a determinados padrões, que são reconhecidos, partilhados e aceitos.

Simbolização da unidade: símbolos da unidade, de identidade e identificação coletivos são criados e difundidos.

Diferenciação: ênfase em características de grupos ou indivíduos de forma a dificultar sua participação no exercício do poder.

Expurgo do outro: construção social de inimigo, a quem são atribuídas características negativas, aos quais as pessoas devem resistir.

Estigmatização: "a desapropriação de indivíduo(s) ou grupo(s) do exercício de sua humanidade pela valorização de uma deficiência ou corrupção de alguma condição física, moral ou social" (Andrade, 2004, p.107-108). 
Reificação: processos são retratados como coisas. Situações históricas e transitórias são tratadas como atemporais, permanentes e naturais.

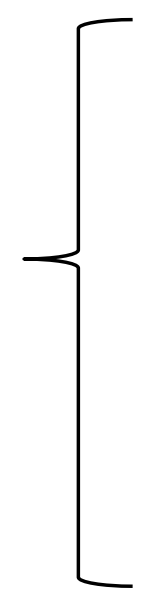

Naturalização: fenômeno social ou histórico é tomado como natural e inevitável.

Eternalização: fenômeno social ou histórico é tomado como permanente, recorrente ou imutável.

Nominalização: transformação de partes de frases ou ações descritas em nomes, ou substantivos, atribuindo-lhes sentido de coisa.

Passifização: uso da voz passiva que leva à retirada das ações.

Fonte: Adaptado a partir de Thompson (2011), Silva F.(2009) e Oliveira (2016)

O discurso, então, pode ser concebido como um ponto de articulação entre os processos ideológicos e os linguísticos. Brandão (2004, p. 11) lembra que a linguagem, enquanto discurso, não constitui um universo de signos que serve apenas como instrumento de comunicação ou suporte de pensamento, mas, sim, como interação e como um modo de produção social. Dessa forma, a linguagem não é neutra e não pode ser estudada fora da sociedade, uma vez que os processos que a constituem são sócio-históricos.

O signo deve ser compreendido em um contexto preciso a fim de que o significado seja entendido. Para tanto, são estabelecidos critérios regidos pelas convenções humanas, com a escolha do tempo e do lugar para se utilizar um signo específico. Esses critérios de atributos são construídos socialmente e, uma vez incorporados, passam a formar a identidade (FAIRCLOUGH, 2003; ARCHER, 2000). Sugerem Sato e Júnior J. (2013, p. 21) que os sistemas de valoração de um grupo social, mediante a formação de atributos, contribuem para uma construção ideológica, o que acarreta a absorção dos valores estipulados e estabelecidos pelo grupo social. Isso denota, então, que as práticas ensinadas são reproduzidas e, principalmente, as que são adotadas para gênero, etnia, idade, autoridade e tantas outras. Conforme Bakhtin (1995),

O signo se cria entre indivíduos, no meio social; é portanto, indispensável que o objeto adquira uma significação interindividual; somente então é que ele poderá ocasionar à formação de um signo. Em outras palavras, não pode entrar no domínio da ideologia, tomar forma e aí deixar raízes senão aquilo que adquiriu um valor social. (BAKHTIN, 1995, p. 45) 
A propósito, segundo Bakhtin (2002, p. 31), "tudo que é ideológico é um signo. Sem signo não existe ideologia", pois cada signo ideológico não é apenas um reflexo, uma sombra da realidade, mas é, também, um fragmento material dessa realidade. Todo fenômeno que funciona como signo ideológico tem encarnação material, seja como som, como massa física, como cor, como movimento do corpo ou como qualquer outro aspecto. O signo é capaz de veicular inúmeras ideologias e intencionalidades.

Com base nesse entendimento, a relação proposta de signo e ideologia, no presente estudo, é a de que no militarismo, inclusive nos Colégios Militares, os signos revelam disciplina, ordem, hierarquia e rigidez voltados para formação de um segmento social já integrado na sociedade. No entanto, nas instituições que buscam ressocializar e reeducar adolescentes, esses mesmos signos revelam práticas sociais geralmente repressoras voltadas para a penalidade e para a "correção".

Na chancela do pensamento de Silva T. (2009), de que existem inúmeras marcas de poder, enfatizo que este estudo se fundamenta nas relações assimétricas de poder no que tange à autoridade e à obediência, pois analiso uma relação em que há alguém que tem e exerce o poder de disciplinar e alguém que deve obedecer às ordens dadas. A palavra "poder" vem do latim vulgar pǒtēre, substituído no latim clássico por posse. Como verbo transitivo, pode significar: ter faculdade de, ter possibilidade de, ter força para. Como substantivo masculino, pode ter o sentido de: direito de deliberar, agir, mandar; autoridade, soberania, domínio, capacidade. Não obstante, na prática, a etimologia da palavra poder exprime ação, força, autoridade. Ressalte-se que o poder é exercido tanto por indivíduos como por instituições e, dificilmente, haverá alguma modificação em termos de pensamento e comportamento daqueles que o detêm. Vale ressaltar, de acordo com Wodak (2004), que

a linguagem classifica o poder, expressa o poder e está presente onde há disputa e desafio ao poder. $O$ poder não surge da linguagem, mas a linguagem pode ser usada para desafiar o poder, subvertê-lo, e alterar sua distribuição a curto e longo prazo. (WODAK, 2004, p. 237)

As formas linguísticas são usadas, também, em expressões e manipulações do poder. Ressalte-se que esse poder é sinalizado tanto nas formas léxico-gramaticais presentes em um texto, quanto por meio do controle que uma pessoa exerce sobre uma ocasião social por meio do gênero textual/discursivo. Conforme afiança Fairclough (2001), o poder deve ser considerado em sua dialética: como local de poder e como afirmação de poder. É devido a essa dialética que a ADC deve ser reflexiva em sua postura institucional, pois a "teoria é ela 
própria uma prática" (CHOULIARAKI; FAIRCLOUGH 1999, p. 29). Portanto, ao conjugar seu pensamento às ideias foucaultianas, de perceber discursos como diferentes formas posicionadas de significar domínios de prática e conhecimento, Fairclough desenvolve uma teoria de discurso como luta hegemônica em que poder é exercido para construir a realidade social por meio de controle intertextual de práticas discursivas. Essa visão configura mais uma forma de conceber o discurso, um momento entre outros da prática social, permeado por relações de poder (FOUCAULT, 1979).

O poder, de acordo com Foucault (1980, p. 98), é organizado como uma rede, na qual os sujeitos participam como "alvos que consentem" e, ao mesmo tempo, como "elementos de sua articulação". Para o autor (1995), o exercício de poder é “uma ação sobre ações”. Uma relação de poder é a ação que não age direta e imediatamente sobre os outros, mas que age sobre sua própria ação. Essa relação articula-se "sobre dois elementos que lhe são indispensáveis para ser justamente uma relação de poder: que o 'outro' (aquele sobre quem ela se exerce) seja reconhecido e mantido até o fim como sujeito de ação; e que se abra diante da relação de poder todo um campo de respostas, reações, efeitos, invenções possíveis" (FOUCAULT, 1995, p. 243). Essas relações foram marcadas pela disciplina, seja em escolas, prisões, instituições ou quartéis. Dessa forma, é por meio da disciplina que podem ser notadas as relações de poder, pois são estabelecidas as relações de quem manda e de quem obedece, do opressor e do oprimido, ou melhor dizendo, as relações daqueles que comandam e daqueles que são comandados.

Hall (2005) lembra que, sob a ótica da história do sujeito moderno, apesar de o poder disciplinar de Foucault ser o produto das novas instituições coletivas e de grande escala da modernidade tardia, suas técnicas compreendem uma aplicação do poder e do saber que individualizam ainda mais o indivíduo e envolvem intensamente o seu corpo. Sendo assim, por meio da vigilância, da observação constante, as pessoas sujeitas ao controle são individualizadas. Nessa vertente, Dreyfus e Rabinow (1982, p. 159) observam que "o poder não apenas traz a individualidade para o campo da observação, mas também fixa aquela individualidade objetiva no campo da escrita”. Com isso, a construção das identidades é realizada de dentro e não fora do discurso. Conforme preconiza Hall (2012), é preciso que as identidades sejam compreendidas como: 
produzidas em locais históricos e institucionais específicos, no interior de formações e práticas específicas, por estratégias e iniciativas específicas. Além disso, elas emergem no interior do jogo de modalidades específicas de poder e são, assim, mais o produto, de marcação da diferença e da exclusão do que o signo de uma unidade idêntica. (HALL, 2012, p. 109)

O poder exercido, portanto, não é compreendido como propriedade, mas como estratégia, suposto na microfísica do poder. Assim, seus efeitos de dominação não devem ser atribuídos a uma "apropriação", mas sim "a disposições, a manobras a táticas, a técnicas, a funcionamentos" (FOUCAULT, 1979, 2004), como é o caso do Regimento Interno das duas instituições em tela: Colégio Militar de Brasília e Unidade de Internação de Santa Maria.

\subsubsection{Discurso como representação}

As três metafunções apresentadas por Halliday (2004) (interpessoal, ideacional, textual) são denominadas por Fairclough (2003) significados do discurso, como já mencionado. Fairclough (2003, p. 27) sugere uma abordagem das funções baseada na relação do texto com o evento, com o mundo físico e social e com pessoas (RAMALHO, 2006). Nessa perspectiva, a semiose é vista segundo os principais significados do discurso: acional, representacional e identificacional. Esses significados equivalem às formas de como a semiose figura em práticas sociais (tais como: os modos de agir, modos de representar e modos de ser) e aos elementos que compõem as ordens de discurso: gêneros, discursos, estilos.

Afirma Silva D. (2009, p. 66) que reforçar o diálogo entre a LSF e ADC é fundamental para a compreensão das relações de poder. Portanto, o texto, além de envolver simultaneamente as funções ideacional, interpessoal e textual, deve ser visto como ação (gênero), representação (discurso) e identificação (estilo), que são os três elementos de ordem do discurso. Nessa perspectiva, o analista crítico pode refinar seus estudos combinando a LSF e a ADC, pois, enquanto a LSF se preocupa com o estudo das escolhas linguísticas (registro) para agir e interagir em um contexto de cultura (gênero), a ADC se preocupa com as ordens do discurso, as relações de poder que forçam essas escolhas linguísticas.

Filio-me à concepção estabelecida por Fairclough (2001, p. 91), no sentido de que “discurso é uma prática, não só de representação do mundo, mas de significação do mundo, constituindo e construindo o mundo em significado". Logo, discurso, nesta pesquisa, envolve uma inter-relação dialética com a estrutura social acarretando um modo de ação e também de representação. 
Diante disso, entende-se por discurso disciplinador a prática de elementos de ordem do discurso que costumam refletir práticas sociais reguladoras de conduta e comportamento para o cumprimento de normas e regras, com tais elementos encontrados e configurados em representações linguístico-discursivas. Essa referida prática propõe-se a fortalecer uma visão racional do ser humano como ator social consciente de si mesmo e das leis inerentes à educação, à ética e à cidadania. No âmbito da educação, objetiva o aprendizado a fim de se ter formação plena e cidadã do sujeito. Na concepção social, os objetivos irão abranger os conceitos existentes em estudos formais dos padrões morais, de conduta direcionada à disciplina e comportamentos para a convivência em sociedades.

Esse discurso disciplinador causa um efeito contínuo, pois afeta a construção da identidade de quem o ouve. Já nas vozes de quem o emite, ele é recontextualizado, com escolhas lexicais a fim de que haja "um processo interativo de produção de significado" (FAIRCLOUGH, 2003), ou seja, o efeito disciplinador esperado.

Nesse tipo de discurso, há marcas evidentes de poder, que, em situações particulares, podem refletir mecanismos multiplicadores de discursos que contribuem na formação positiva ou negativa do ator social, bem como na produção do saber.

\section{Algumas considerações}

Neste capítulo, vimos duas propostas teórico-metodológicas que interagem e se complementam: a Análise de Discurso Crítica (ADC), nos moldes de Fairclough (2001, 2003, 2010), para quem linguagem e sociedade estão interconectadas dialeticamente e a LSF teoria da linguagem desenvolvida por Halliday (1994) e ampliada em Halliday e Matthiessen (2004). Com essas duas teorias, pode-se trabalhar o lado social da linguagem (discurso) sem que se perca a dimensão da interioridade (gramática), conjugando-se rotinas sociais e formas linguísticas, o que foi complementado pela teoria da Avaliatividade.

Este estudo insere-se na proposta teórica da Teoria Social do Discurso (FAIRCLOUGH, 2001) e na teoria da linguagem desenvolvida por Halliday (1994), uma vez que se propõe a fazer uma interface entre as funções sociais e o sistema interno da língua em forma de análises linguístico-discursivas. Portanto, busca-se, para a concretização desta pesquisa, o uso, na análise dos dados empíricos, da relação dialógica que existe entre as bases funcionais da linguagem, defendidas por Halliday e Matthiessen (2004) e o modelo de ADC desenvolvido por Fairclough (2003). 
No próximo capítulo, serão apresentados e delineados os caminhos teóricometodológicos utilizados na concepção e no desenvolvimento desta tese. 


\section{CAPÍTULO 3 - DELINEAMENTO DO PERCURSO METODOLÓGICO}

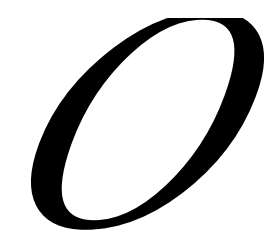

cerne deste capítulo é a apresentação e a discussão de procedimentos teórico-metodológicos utilizados na concepção e no desenvolvimento desta tese. O capítulo metodológico é dividido em sete seções. Na primeira, caracterizo a pesquisa. Apresento, na segunda, os objetivos geral e específicos e as questões de pesquisa. A terceira concerne à definição de pesquisa qualitativa, assim como das estratégias de investigação e dos métodos utilizados na coleta de dados documentais e na geração de dados. Na quarta seção, teço considerações a respeito do CMB e da UISM. As abordagens teórico-metodológicas da LSF e da ADC são apresentadas no quinto capítulo, haja vista a análise dos dados ser feita a partir das diretrizes dessas duas abordagens científicas. Na sexta seção, apresento o programa WordSmith Tools, utilizado na análise linguística de dados desta pesquisa. E, finalmente, na sétima, teço considerações sobre o capítulo.

\subsection{CARACTERIZAÇÃo da PESQUiSA}

Nesta pesquisa, meu propósito é fazer um estudo comparativo de discursos disciplinadores, aplicados, por um lado, a adolescentes em situação de reclusão da Unidade de Internação de Santa Maria (UISM) e, por outro, a estudantes do Colégio Militar de Brasília (CMB). Trata-se de duas instituições oficiais que, embora se alinhem de modo paralelo, em termos de princípios de formação disciplinar, pedagógica, cívica e moral, bem como de inserção cultural e (re)integração total do cidadão ao meio social, distanciam-se em termos de práticas sociais. Além disso, faço um estudo das representações linguístico-discursivas dos adolescentes, ao identificar, por meio de categorias, como eles se representam ao (des)construir seus mundos (físico, biológico e social). Ademais, traço um paralelo por contraste e discirno onde os discursos dos adolescentes se alinham e onde se afastam.

Busco, portanto, identificar a realidade dos adolescentes, principalmente a dos socioeducandos, face à representação discursiva da voz desses atores sociais e dos regimentos internos. Nesse sentido, para que se compreenda essa realidade, é necessário definir e delinear os tipos de operacionalização do trabalho. Em vista disso, optei pela pesquisa qualitativa (descritiva e interpretativa), que lida com interpretações da realidade social. A linguista argentina Pardo (2011, p. 25) salienta que "esse tipo de pesquisa envolve um conjunto de 
práticas interpretativas e materiais que fazem com que o mundo seja observável e também transformado". No contexto brasileiro, tem-se uma questão relevante concernente à pesquisa qualitativa. Nas palavras de Resende (2008, p. 103), “discussões acerca de ética em pesquisa qualitativa têm favorecido métodos colaborativos de pesquisa, em que o objetivo do pesquisador não é apenas pesquisar sobre ou para sujeitos, mas pesquisar sobre, para, com sujeitos participantes do projeto de pesquisa”. Por conseguinte, a qualidade pode ser vista como uma condição para a pesquisa eticamente adequada, que propicia uma pesquisa séria, com credibilidade e fidedigna à análise dos dados, ou seja, que apresenta um profícuo caminho metodológico.

\subsection{OBJETIVOS E QUESTÕES DE PESQUISA}

A partir dessa perspectiva teórico-metodológica, elenco os objetivos, geral e específicos, bem como as questões de pesquisa, que delineiam os caminhos da presente tese.

\subsubsection{Objetivo geral}

Discutir, à luz da Análise de Discurso Crítica e da Linguística Sistêmico-Funcional, as representações linguístico-discursivas voltadas para adolescentes do Colégio Militar de Brasília e da Unidade de Internação de Santa Maria em Documentos Oficiais.

\subsubsection{Objetivos específicos}

- Mostrar como se efetuam as representações linguístico-discursivas de adolescentes em Documentos Oficiais;

- apontar quais as semelhanças e as diferenças entre os regimentos do CMB e da UISM;

- contrastar, à luz do pensamento foucaulteano, os instrumentos disciplinares previstos nos Colégios Militares e nas Unidades de Internação;

- elencar as categorias linguístico-discursivas mais recorrentes nos relatos dos adolescentes;

- discernir em que momento os discursos dos adolescentes pertinentes aos dois contextos da capital federal se alinham e onde se afastam em relação à redução da maioridade penal. 
Os objetivos acima encontram-se relacionados às seguintes questões:

\subsubsection{Questões de pesquisa}

1) Como os adolescentes são representados e identificados nos Documentos Oficiais?

2) Quais são as semelhanças e as diferenças entre os regimentos dos Colégios Militares e das Unidades de Internação do DF?

3) Quais as semelhanças e diferenças dos instrumentos disciplinares indicados por Foucault nas instituições CMB e UISM?

4) Quais categorias linguístico-discursivas são encontradas nos relatos dos adolescentes?

5) Em que momento os discursos dos adolescentes, no que se refere ao tema da redução da maioridade penal, alinham-se e quando se afastam?

\subsubsection{Problema}

O propósito almejado é buscar aproximar respostas a outra indagação concernente à discussão encetada no objetivo geral:

- O que está escrito nos regimentos dos Colégios Militares e das Unidades de Internação do Distrito Federal é cumprido?

Discutir representações linguístico-discursivas voltadas para adolescentes exige a descrição do mundo que abarca um fenômeno social mais amplo para, então, interpretar um dado fenômeno social na sua exterioridade. Trata-se da escolha de um caminho balizado por procedimentos pertinentes a uma pesquisa de natureza qualitativa, tema enfocado a seguir.

\subsection{A PESQUiSA QUALITATIVA}

A pesquisa qualitativa é um campo de investigação que trata com interpretações de uma realidade social que situa e localiza o observador no mundo. Denzin e Lincoln (2006) lembram que esse tipo de pesquisa envolve um conjunto de práticas materiais e interpretativas que transformam o mundo em uma série de representações. Mais que uma técnica de coleta de dados, e menos do que um novo paradigma de análise e interpretação, o procedimento qualitativo traz uma nova visão, um novo questionamento, permitindo reconceituar as problemáticas sociais (GROULX, 2012, p. 95). 
Na perspectiva de Stake (2011), qualitativa remete a um raciocínio que se baseia primordialmente na percepção e na compreensão humana. Por isso, adotei a pesquisa qualitativa, já que "a mensuração dos fatos sociais depende da categorização do mundo social" (BAUER, GASKELL; ALLUM, 2002, p. 24). Logo, é importante ter uma noção das distinções qualitativas entre as categorias, a fim de que se possa entender ou interpretar "os fenômenos em termos dos significados que as pessoas a eles conferem" (DENZIN; LINCOLN, 2006, p. 17).

A propósito, para Flick (2009a, p. 8), a pesquisa qualitativa versa sobre dois contextos: "o mundo lá fora" e o "de dentro", em que entende, descreve e, às vezes, explica os fenômenos sociais. Entretanto, para o autor, a análise de experiências de indivíduos e grupos, a observação de interações ou comunicações que estejam se desenvolvendo, a investigação de documentos ou traços semelhantes de experiências ou interações são diferentes abordagens para esmiuçar, descrever e explicar as questões sociais. Dessa forma, procura-se, aqui, detalhar a maneira como adolescentes do CMB e da UISM enxergam e constroem o mundo à sua volta, os significados de seus atos, crenças, experiências e valores e como ressignificam seu mundo.

Levando-se em conta as diversas atividades interpretativas que possibilitam descrever e interpretar as representações do mundo, a pesquisa qualitativa permite a coleta de materiais empíricos e várias práticas interpretativas para que se compreenda o ponto em questão investigado. Por esse motivo, a presente pesquisa é de natureza qualitativa de cunho descritivo e se desenvolve com interpretações de realidades sociais, quais sejam, o Regimento Interno das Unidades de Internação e o Guia de Aluno e Responsável, vinculado ao Regimento Interno dos Colégios Militares. Ambos são Regimentos Internos e tratam, além de outros temas, da parte disciplinar. Os dois Regimentos Internos têm como objetivos comuns educar, disciplinar e aperfeiçoar padrões cívicos e morais da criança, do jovem e do adolescente. Cabe observar que se propõe, aqui, investigar a representação dos adolescentes da UISM e do CMB em relação aos eventos discursivos presentes nesses regimentos.

Ademais, faço uso da triangulação que, de acordo com Flick (2009a, p. 62), “deve produzir conhecimento em diferentes níveis, o que significa que eles vão além daquele possibilitado por uma abordagem e, assim, contribuem para promover a qualidade na pesquisa". A triangulação pode ser aplicada como uma abordagem para ampliar e complementar, sistematicamente, as possibilidades de elaboração e realização do conhecimento. Nessa esteira, conforme Cohen e Manion (1983, p. 233), esse método pode ser definido como o uso de dois ou mais métodos de coleta/ geração de dados no estudo de 
qualquer aspecto do comportamento humano. Sugere Stubbs (1983, p. 234), que o termo triangulação é usado de diferentes maneiras, entretanto se refere essencialmente à coleta e à comparação de diferentes perspectivas de uma situação.

Ressalte-se que, além da análise linguística de discursividades constituintes do corpus básico da pesquisa, dos Regimentos Internos, propõe-se, aqui, a geração de outros dados, com instrumentos efetuados por meio de dois procedimentos de coleta de duas naturezas: a seleção de dados documentais e geração de dados de natureza etnográfica. Nessa perspectiva, portanto, é feita uma triangulação entre o corpus documental, os Regimentos Internos das Unidades de Internação e do Colégio Militar de Brasília; O Estatuto da Criança e do Adolescente de 1990; e entrevistas com os socioeducandos da UISM e estudantes do CMB.

\subsubsection{Estratégias de Investigação}

A pesquisa qualitativa é de particular relevância ao estudo das relações sociais devido à pluralização das esferas da vida. Há uma gama de métodos que podem ser utilizados na geração de dados em uma pesquisa qualitativa.

No caso desta pesquisa, as propostas metodológicas inserem-se no campo de estudo no qual o pesquisador busca investigar o envolvimento da linguagem na vida social, ou seja, na Análise de Discurso Crítica. Isso, porque a ADC é uma proposta metodológica de trabalho com o texto que possibilita considerar a articulação de áreas e condições sociais diversas no momento do cruzamento dos dados analisados (FAIRCLOUGH, 1989, 2001, 2003, 2010; CHOULIARAKI; FAIRCLOUGH, 1999). Salienta-se que esse método permite a identificação, no texto, de obscuridades, incertezas e interpretações múltiplas e de questões de relações de poder, por levar em conta o sentido potencial dos signos e os perceber como socialmente motivados. (FAIRCLOUGH, 2001).

De acordo com Pacheco (2006), a possibilidade de mudança social suscitada pela ADC encontra amparo em aspectos como a natureza constitutiva do discurso, a primazia da interdiscursividade e da intertextualidade, a natureza discursiva do poder, além da natureza política do discurso e da natureza discursiva de mudança social. É importante destacar que, nesta tese, há o "propósito explícito de contribuir para uma mudança social específica em favor dos grupos dominados", como observa van Dijk (2008, p. 16), e uma das contribuições almejadas é a tentativa da reintegração de adolescentes reclusos em unidades de internação que sairão dessas instituições, quando tiverem cumprido o tempo estipulado da apreensão, e irão viver e conviver em sociedade. 
A ADC propõe um diálogo entre a Ciência Social Crítica e a Linguística, especificamente a Linguística Sistêmico-Funcional (LSF). Por conseguinte, enquanto proposta teórico-metodológica, ADC associa-se à Linguística Sistêmico-Funcional (LSF), teoria da linguagem desenvolvida por Halliday (1994) e ampliada em Halliday e Matthiessen (2004), pois permite descrever de maneira detalhada o impacto de contextos culturais e situacionais sobre o uso da linguagem assim como os padrões de uso da linguagem interagem com estruturas sociais e ideologias. Cabe aqui ressaltar a importância da LSF no âmbito do projeto ora apresentado, uma vez que se trata de uma teoria que envolve a identificação de estruturas de linguagem, o que contribui para o alcance dos sentidos de um texto, bem como das significações subjacentes ao discurso nele veiculado. Destaca-se que a LSF permite a descrição detalhada e sistematizada do impacto de contextos culturais e situacionais sobre o uso da linguagem (EGGINS, 1994).

A ADC se insere em um campo de estudo no qual o pesquisador busca investigar o envolvimento da linguagem na vida social, cujo sistema aberto é formado por práticas e a LSF pode ser compreendida como um sistema de opções disponíveis na língua, já que o falante ou o escritor realizam suas escolhas dentro desse sistema, sempre num contexto de situação social de fala ou de escrita. Com isso, nota-se que uma proposta complementa a outra.

Dessa forma, a fim de que os objetivos propostos sejam contemplados, bem como as questões respondidas, serão traçadas estratégias metodológicas em três dimensões: 1) princípios do delineamento; 2) geração de dados; e 3) análise de dados, conforme o quadro abaixo:

\section{Quadro 3.1 - Dimensões do processo de pesquisa}

\begin{tabular}{|c|r|c|}
\hline Princípios do delineamento & Geração de dados & Análise de dados \\
\hline Pesquisa documental & $\begin{array}{r}\text { Coleta de textos institucionalizados } \\
\text { (documentos legais) }\end{array}$ & \\
\hline Observação participante & $\begin{array}{r}\text { Observação sistemática, entrevistas } \\
\text { individuais, notas de campo }\end{array}$ & $\begin{array}{c}\text { ADC (discurso/exterioridade) e } \\
\text { LSF (gramática/interioridade) }\end{array}$ \\
\hline Estudo comparativo & Gêneros situados (textos institucionais) e \\
desencaixados (entrevistas) & \\
\hline
\end{tabular}

Fonte: Adaptado de Bauer, Gaskell e Allum (2002, p. 19) 
Uma investigação que pretenda desvendar um objeto de natureza qualitativa deve prever a utilização de uma estratégia que permita a apreensão dos sentidos dos fenômenos, e, ao mesmo tempo, respeite sua complexidade, riqueza e profundidade (UCHIMURA; BOSI, 2007, p. 93). Para tanto, é necessário que sejam traçados alguns importantes percursos para a construção do corpus da pesquisa. O Quadro 3.1, por exemplo, permite-nos destacar o planejamento no percurso metodológico delineado para esta tese.

Esta é uma pesquisa que envolve dados empíricos colhidos por meio de procedimentos metodológicos de natureza etnográfica, tais como: observação participante tanto no Colégio Militar de Brasília (CMB), quanto na Unidade de Internação de Santa Maria (UISM); entrevistas com estudantes e com os adolescentes em situação de internação; notas de campo para sistematização das observações e informações colhidas em ambas instituições. Por meio da pesquisa de natureza etnográfica, investiga-se, não apenas a representação de mundo dos adolescentes do CMB e da UISM, mas também os significados por eles atribuídos, em relação aos discursos disciplinadores, a que estão subordinados. Busca-se, também, uma triangulação de dados, com o propósito de imprimir validade à análise dos dados etnográficos, uma vez que foram realizadas observação participante e notas de campo.

Cabe ressaltar que esta pesquisa procura fortalecer o diálogo teórico entre a ADC (discurso/exterioridade) e a LSF (gramática/interioridade), ou seja, o lado social da linguagem (discurso) e a dimensão da interioridade (gramática). Para tanto, a análise se baseia nessas duas propostas teórico-metodológicas, para investigar as representações linguísticodiscursivas de adolescentes, principalmente, dos que não têm voz: os socioeducandos.

Com o intuito de compreender o discurso dos estudantes e dos adolescentes em situação de reclusão, são utilizados métodos da pesquisa qualitativa, quais sejam, entrevistas, conversas e observações que possibilitam buscar as formas de representar (representação), de agir (ação) e de identificar (identificação), em materiais empíricos (documentos legais, regimentos, relatos e depoimentos de adolescentes). A próxima seção envolve uma explanação a respeito da coleta de amostras e geração de dados.

\subsubsection{Dados em foco: coleta e geração de dados}

O corpus desta pesquisa envolve dois procedimentos: geração de dados documentais e geração de dados de natureza etnográfica. Portanto, aqui, há dois tipos de corpora: o documental, com destaque para os Regimentos Internos das Instituições e o empírico, que 
envolve a observação participante e as anotações de campo, além das entrevistas geradas com adolescentes do Colégio Militar de Brasília e da Unidade de Internação de Santa Maria.

A seguir, tanto a geração de dados de natureza etnográfica quanto a de dados de natureza documental serão detalhadas.

\subsubsection{CORPUS DOCUMENTAL}

A palavra corpus é de origem latina e significa corpo. Barthes (1967, p. 96) define corpus como "uma coleção finita de materiais, determinada de antemão pelo analista, com (inevitável) arbitrariedade, e com a qual ele irá trabalhar". Fazem parte do corpus documental dessa pesquisa o Regimento Interno das Unidades de Internação do Distrito Federal, o Regimento Interno dos Colégios Militares. Complementam esse corpus a Constituição Federal de 1988, o Estatuto da Criança e do Adolescente de 1990, o Projeto Político Pedagógico das Medidas Socioeducativas no Distrito Federal, o Regimento Interno da Unidade de Internação de Santa Maria e o Guia do Aluno e Responsável do Colégio Militar de Brasília.

Os regimentos são basilares na análise discursiva deste trabalho. Por isso, serão apresentadas, a seguir, características referentes a esses dois documentos:

- O Regimento Interno das Unidades de Internação do Distrito Federal caracterizase da seguinte forma:

$>$ trinta e cinco páginas, dividido em sumário, oito capítulos, seções dentro dos capítulos e cem artigos;

apresenta como tópicos: disposições gerais; direitos, deveres e estímulos; recepção, acolhimento, plano individual de atendimento; transferência e remoções; políticas sociais; segurança; regulamento disciplinar; revisão e divulgação do regimento.

Cabe destacar que foi elaborado pela Subsecretaria do Sistema Socioeducativo, vinculada à Secretaria de Estado da Criança, inseridas no Governo do Distrito Federal.

- O Regimento Interno dos Colégios Militares caracteriza-se da seguinte maneira:

quarenta e seis páginas, dez títulos, divididos em capítulos e seções e cento e trinta e oito artigos.

apresenta como tópicos: estabelecimento de ensino, princípios e finalidades; organização; atribuições; cursos; inclusão e exclusão; contribuições e encargos dos responsáveis; regime escolar; corpo docente; corpo discente; disposições transitórias e prescrições diversas. 
Observe-se que Guia de Aluno e Responsável vincula-se ao Regimento Interno dos Colégios Militares; e esse está subordinado ao Regulamento dos Colégios Militares (R69), como veremos no próximo capítulo.

\subsubsection{GERAÇÃO DE DADOS DE NATUREZA ETNOGRÁFICA}

Nas palavras de Agrosino (2009, p. 30) “a etnografia é a arte e a ciência de descrever um grupo humano - suas instituições, seus comportamentos interpessoais, suas produções materiais e suas crenças". Já Chouliaraki e Fairclough (1999, p. 61) argumentam a favor da etnografia para a ADC, pois, assim como os relatos de histórias de vida, a etnografia pode contribuir significativamente para a compreensão dos mecanismos sociais de dominação e resistência ou de emancipação e de transformação social. Ressalte-se, entretanto, que esta pesquisa não é etnográfica, mas, sim, utiliza métodos de natureza etnográfica. Isso, porque me apropriei de orientações da etnografia para interpretar e descrever as discursividades de práticas disciplinadoras e as representações linguístico-discursivas de adolescentes.

\subsubsection{ENTRADA NO CAMPO E QUESTÕES DE ÉTICA}

Para desenvolver este estudo, submeti o projeto de tese ao Comitê de Ética e Pesquisa com Seres Humanos. ${ }^{10}$ Depois de alguns ajustes feitos, pedidos pelo Comitê de Ética, minha pesquisa foi aprovada e, dessa forma, entrei no campo da pesquisa.

O termo "campo" pode designar uma determinada instituição, uma subcultura, uma família, um grupo específico (FLICK, 2009). Objetivando o início desta pesquisa, fui às instituições (CMB e Vara da Infância e Juventude) pegar autorização para conversar e entrevistar os adolescentes. Destaque-se que, primeiramente, uma parte deste estudo seria feito na Unidade de internação do Recanto das Emas - UNIRE. Elaborei o documento para entregar à juíza da Vara de Infância e Juventude, informando-lhe o teor do trabalho; peguei a autorização da juíza e da coordenadora de Articulação do Sistema Socioeducativo. Logo após, conheci a UNIRE, conversei com psicóloga, assistente social, pedagoga, professores, e profissionais diversos dessa instituição, conheci a escola da instituição e passei pelas salas de aula enquanto estavam ocorrendo os eventos educacionais, presenciei alguns "banhos de sol" dos internos e conversei com alguns adolescentes em situação de reclusão.

${ }^{10}$ O Comitê de Ética e Pesquisa com Seres Humanos tem caráter inter e transdisciplinar e conta com a participação de profissionais da área biomédica, das ciências sociais e usuários do sistema de saúde. 
Entretanto, nesse ínterim, foram finalizadas as construções de novas Unidades de Internação, a fim de que houvesse uma redistribuição, por idade, dos socioeducandos e desativada a Unidade do Caje ${ }^{11}$. Observei que na UNIRE só ficariam os jovens de 18 a 21 anos, faixa etária que não contemplava a idade estimada para a minha pesquisa. Dessa forma, tive de recomeçar todo o processo: conseguir todas as autorizações para conversar com os socioeducandos e para entrevistá-los, já que teria de contextualizar, novamente, minha pesquisa na UISM, uma das instituições onde estão meninas e meninos de 12 a 17 anos.

Sendo assim, entrevistei parte dos socioeducandos da UISM e recebi o convite da então diretora da Unidade de Internação para trabalhar leitura e produção de texto com os adolescentes dessa instituição. Esse trabalho voluntário se desenvolveu da seguinte forma: os adolescentes liam o livro que desejavam ler e faziam um resumo da obra escolhida. Meu trabalho didático-pedagógico restringia-se à correção da parte gramatical e estrutural do texto e, em seguida, a interação com um adolescente por vez, momento em que explicava o que poderia ser melhorado e mudado nos textos. Além disso, conversávamos sobre as obras lidas por eles. Porém, muitos faziam uma espécie de "terapia" comigo, contando seus problemas e angústias, bem como desejos de mudança, porque sentiam a necessidade de falar e compartilhar com alguém sobre sua vida. Nesse período de interação pedagógica, fiz mais algumas entrevistas com os socioeducandos. Esses eventos ocorriam na biblioteca da Unidade de Internação. Por problemas de deslocamento e por falta de efetivo de policiais, às vezes, ficavam dois socioeducandos na biblioteca; enquanto um escolhia o livro que iria levar para o quarto (cela), o outro ficava comigo. Na biblioteca, havia sempre um agente junto a mim e aos adolescentes. Eu ia à UISM uma vez ou duas vezes por semana, no período da manhã.

Essa experiência foi engrandecedora, pois pude perceber que minha pesquisa estava imbuída de uma prática social transformadora, porque, durante esse período, foram realizadas atividades de leitura e produção de texto, que mostraram a alguns colaboradores-participantes uma outra perspectiva de visão de mundo, quais sejam, o gosto pela leitura, o empenho na escrita, a tentativa de melhorar o que já havia sido feito. Sabia que apenas analisar os documentos escritos e entrevistar os adolescentes não me fariam aprofundar o estudo, como o fiz. Dessa maneira, destaco que todos os elementos envolvidos, tais como, a análise documental, as análises das entrevistas e o contato direto com os envolvidos em suas rotinas embricaram-se para que a pesquisa se tornasse mais consistente.

${ }^{11}$ Caje: Unidade de Internação do Plano Piloto (UIPP). Essa Unidade sempre teve um grande problema de superlotação, o que acarretou, além de outros fatores, muitas mortes de adolescentes internos. 
No Colégio Militar de Brasília, onde sou professora de Língua Portuguesa há dezoito anos, obtive a autorização do chefe da Divisão de Ensino (DE) para realização da pesquisa e lhe expliquei o porquê do estudo e os passos que daria para o desenvolvimento e execução do trabalho. Além disso, mostrei-lhe o Termo de Assentimento e o Termo de Consentimento Livre e Esclarecido, elaborados por mim, necessários para entrevistar os estudantes com idade inferior a 18 anos. Com a autorização da DE em mãos, fui à procura de professores de Língua Portuguesa, de variadas séries/anos a fim de conversar cinco minutos com os alunos para saber quem poderia ser voluntário nas entrevistas. Quando obtive as respostas positivas dos estudantes, entreguei-lhes os Termos para levarem para casa e serem assinados por eles e pelos responsáveis. Com os Termos assinados, logo após, iniciei as entrevistas com os alunos do CMB.

Essas autorizações, para dar seguimento à pesquisa, estão inseridas em pressupostos referentes às questões éticas. Fazem parte de princípios éticos na pesquisa qualitativa, pois esse consentimento cientificado dos participantes significa informá-los sobre a pesquisa e a solicitação de sua participação no projeto formalmente com "um contrato escrito e assinado" (FLICK, 2009). Conforme Silva (2003, p. 161), “o trabalho de campo coloca o(a) pesquisador(a) diante de uma situação de contato relativamente íntima com a vida dos observados". Sendo assim, pesquisador e observado passam a ter mais proximidade e essa estreita fronteira deve ser trabalhada de forma séria e responsável para que sejam evitados problemas de constrangimento, humilhação e exposição - física ou mental - dos participantes, que, nesta pesquisa, são os adolescentes do Colégio Militar de Brasília e da Unidade de Internação de Santa Maria.

Os participantes ou os colaboradores adolescentes entrevistados têm o seguinte perfil: vinte e nove adolescentes, sendo dezesseis da UISM e treze do CMB, entre adolescentes do sexo feminino e do sexo masculino, de 12 a 17 anos e que podem estar cursando ou ter cursado qualquer ano escolar. Ressalte-se que tanto a identidade do entrevistado, seja dos adolescentes - participantes, ou dos funcionários - colaboradores - da Unidade de Internação de Santa Maria e do Colégio Militar de Brasília que se dispuseram a colaborar com seus relatos, será resguardada. Cabe, aqui, esclarecer que os adolescentes da UISM, assim como do CMB são apresentados com pseudônimos que evocam os evangelistas, bem como os nomes bíblicos. Tal escolha se encontra, por um lado, em conformidade com o que é exigido pelo ECA, no que concerne a segredo de justiça e, por outro, pelo propósito de valorizar a voz e as experiências pessoais dos adolescentes. Além disso, trata-se, também, de uma postura ética da autora. 


\subsubsection{ENTREVISTAS}

Para levar a cabo a investigação das representações linguístico-discursivas dos estudantes e dos socioeducandos, um tema que requer atenção tanto na área educacional como na social, faz-se necessário reunir um material de estudo resultante de dois procedimentos metodológicos de natureza etnográfica:
a) entrevistas;
b) gravação (em áudio) com gravador.

A entrevista é uma metodologia de coleta de dados. Neste trabalho, é usada como um meio de geração de dados. Gaskell (2011, p. 65) lembra que "a compreensão dos mundos da vida dos entrevistados e de grupos sociais especificados é a condição sine qua non da entrevista qualitativa”. Destaca-se que essa compreensão oferecida por esse meio pode fornecer subsídios e esclarecimentos indispensáveis para elucidar as realidades sociais.

Escolhi esse recurso metodológico por ser um processo social interacional díade, uma troca de ideias e de significados em que diversas realidades e percepções são exploradas e desenvolvidas. Esse método auxilia na percepção e na descoberta de perspectivas ou pontos de vista sobre os fatos, além daqueles internalizados e pré-concebidos pelo entrevistador.

As entrevistas episódicas foram utilizadas, no âmbito da pesquisa, como meio de geração de dados. O objetivo desse procedimento foi o de compreender o contexto sociocultural dos adolescentes, com temas que envolveram questões disciplinares e institucionais. Porém, por meio das respostas, apareceram outros temas relacionados à família e às drogas. Cabe destacar que as entrevistas foram realizadas para traçar questões pertinentes às representações dos adolescentes configuradas em recorrências encontradas nos relatos dos alunos do CMB e dos socioeducandos da UISM.

Flick (2011, p.173) elenca nove passos para a entrevista episódica:

1) Preparação da entrevista: faz-se um guia de entrevista com a finalidade de orientar o entrevistador para os campos específicos a respeito dos quais se buscam narrativas e respostas.

2) Introdução da lógica da entrevista: explica-se o caráter das perguntas para o entrevistado e o familiariza com esta prática.

3) Concepção do entrevistado sobre o tema e sua biografia com relação a ele: pergunta-se ao entrevistado que relembre uma situação específica e que a conte. 
4) Sentido que o assunto tem para a vida cotidiana do entrevistado: esse tipo de pergunta tem como finalidade juntar narrativas de uma cadeia de situações relevantes.

5) Enfoque das partes centrais do tema em estudo: concentra-se nos aspectos-chave do tema.

6) Tópicos gerais relevantes.

7) Avaliação e conversa informal.

8) Documentação.

9) Análise de entrevistas episódicas.

Seguindo esses passos, foram elaboradas perguntas basilares para entrevista com os adolescentes, tanto do CMB quanto da Unidade de Internação, como pode ser observado no Quadro 3.2 abaixo:

\section{Quadro 3.2 - Perguntas básicas para os adolescentes da UISM e do CMB}

PERGUNTAS BÁSICAS PARA OS ADOLESCENTES DA UISM E DO CMB:

$\checkmark$ Você me permite gravar o que vamos conversar aqui?

$\checkmark$ Onde você nasceu?

Onde você mora/morava? Com quem?

$\checkmark$ Onde você estudou antes de vir para cá? Até que série/ano?

$\checkmark$ Por que você veio para cá?

Você passou por alguma situação marcante/difícil/emoção em sua vida? Poderia relatá-la?

$\checkmark$ O que significa obediência para você?

O que significa obedecer para você neste lugar?

$\checkmark$ O que você imagina para seu futuro?

$\checkmark$ O que você aprende aqui o ajudará a conseguir o que você deseja para seu futuro?

Fonte: elaborado pela autora 
Cabe ressaltar que, além dessas perguntas, feitas por meio de entrevistas semiestruturadas, buscou-se trazer, para esta tese, a voz dos socioeducandos da Unidade de Internação de Santa Maria, bem como de estudantes do Colégio Militar de Brasília a respeito do tema 'redução da maioridade penal'. Dessa forma, teceu-se um paralelo, por oposição ou contraste, das opiniões de ambos os grupos de adolescentes. Para tanto, os socioeducandos produziram textos escritos, os quais foram colocados em contraste com os relatos orais dos alunos do CMB.

Conforme lembra Silva (2003), a escolha de pseudônimos atende a um princípio de ética na pesquisa com seres humanos. Nessa esteira de pensamento, o adolescente foi nomeado por um pseudônimo no decorrer da tese, em consonância com cada ficha elaborada no trabalho de campo. Além do pseudônimo, constam, na ficha, o local da entrevista, idade e escolaridade do entrevistado, como se pode observar no quadro abaixo.

Quadro 3.3 - Perfil dos adolescentes da Unidade de Internação de Santa Maria (UISM) e do Colégio Militar de Brasília (CMB)

\begin{tabular}{|c|c|c|c|c|c|}
\hline Pseudônimo & Data & Idade & Escolaridade & UISM & CMB \\
\hline Maria Madalena & 21 set. 2014 & 17 & $6^{\circ}$ ano ens. fund. & $\mathrm{x}$ & \\
\hline David & 23 set. 2014 & 17 & $6^{\circ}$ ano ens. fund. & $\mathrm{x}$ & \\
\hline Felicidade & 23 set. 2014 & 16 & $9^{\circ}$ ano ens. fund. & $\mathrm{x}$ & \\
\hline João Batista & 14 out. 2014 & 16 & $2^{\circ}$ ano ens. médio & $\mathrm{x}$ & \\
\hline Inácio & 03 nov. 2014 & 15 & $4^{\circ}$ ano ens. fund. & $\mathrm{x}$ & \\
\hline Lucas & 06 dez. 2014 & 13 & $6^{\circ}$ ano ens. fund. & $\mathrm{x}$ & \\
\hline João & 05 fev. 2015 & 13 & $7^{\circ}$ ano ens. fund. & & $\mathrm{x}$ \\
\hline Ava & 13 fev. 2015 & 16 & $2^{\circ}$ ano ens. médio & & $\mathrm{x}$ \\
\hline Paulo & 13 fev. 2015 & 16 & $2^{\circ}$ ano ens. médio & & $\mathrm{x}$ \\
\hline Cefira & 13 fev. 2015 & 16 & $2^{\circ}$ ano ens. médio & & $\mathrm{x}$ \\
\hline Elias & 18 março 2015 & 16 & $6^{\circ}$ ano ens. fund. & $\mathrm{x}$ & \\
\hline Isaac & 18 março 2015 & 16 & $2^{\circ}$ ano ens. médio & & $\mathrm{x}$ \\
\hline Moisés & 07 maio 2015 & 17 & $2^{\circ}$ ano ens. médio & & $\mathrm{x}$ \\
\hline Isabel & 07 maio 2015 & 17 & $3^{\circ}$ ano ens. médio & & $\mathrm{x}$ \\
\hline Daniel & 07 maio 2015 & 15 & $2^{\circ}$ ano ens. médio & & $\mathrm{x}$ \\
\hline Ada & 11 maio 2015 & 16 & $6^{\circ}$ ano ens. fund. & $\mathrm{x}$ & \\
\hline Raquel & 21 set. 2015 & 15 & $6^{\circ}$ ano ens. fund. & $\mathrm{x}$ & \\
\hline
\end{tabular}




\begin{tabular}{|l|l|l|l|l|l|}
\hline Pseudônimo & \multicolumn{1}{|c|}{ Data } & \multicolumn{1}{|c|}{ Idade } & \multicolumn{1}{|c|}{ Escolaridade } & UISM & CMB \\
\hline Sara & 21 set .2015 & 14 & $6^{\circ}$ ano ens. fund. & $\mathrm{x}$ & \\
\hline Tomé & 21 set .2015 & 16 & $1^{\circ}$ ano ens. fund. & $\mathrm{x}$ & \\
\hline Abraão & 21 set. 2015 & 16 & $7^{\circ}$ ano ens. fund. & $\mathrm{x}$ & \\
\hline David & 21 set. 2015 & 16 & $6^{\circ}$ ano ens. fund. & $\mathrm{x}$ & \\
\hline Samuel & 16 out. 2015 & 16 & $2^{\circ}$ ano ens. médio & & $\mathrm{x}$ \\
\hline Nazaré & 03 nov. 2015 & 16 & $2^{\circ}$ ano ens. médio & $\mathrm{x}$ & \\
\hline Marta & 03 nov. 2015 & 16 & $6^{\circ}$ ano ens. fund. & $\mathrm{x}$ & \\
\hline Ester & 03 nov. 2015 & 15 & $6^{\circ}$ ano ens. fund. & $\mathrm{x}$ & \\
\hline Mateus & 08 mar. 2016 & 16 & $2^{\circ}$ ano ens. médio & & $\mathrm{x}$ \\
\hline Dalila & 08 mar. 2016 & 16 & $3^{\circ}$ ano ens. médio & & $\mathrm{x}$ \\
\hline Emanuel & 08 mar. 2016 & 17 & $2^{\circ}$ ano ens. médio & & $\mathrm{x}$ \\
\hline Noé & 08 mar. 2016 & 16 & $2^{\circ}$ ano ens. médio & & $\mathrm{x}$ \\
\hline
\end{tabular}

As respostas dos participantes da pesquisa foram analisadas conjugando-se a ADC à LSF. Essas duas propostas teórico-metodológicas foram escolhidas, porque, em ambas, podese trabalhar o lado social da linguagem (discurso) sem que se perca a dimensão da interioridade (gramática).

\subsubsection{A OBSERVAÇÃO PARTICIPANTE}

Nas pesquisas qualitativas, o pesquisador procura constantemente entender os fenômenos, a partir da visão dos participantes, da situação estudada e, então, desse momento em diante, começa a situar sua interpretação dos fenômenos estudados, selecionando os dados. O tipo de informação que o observador participante recebe necessita de ser tratado com grande cautela, como registra Milroy (1987, p. 90). Esse cuidado deve ser evidenciado, porque depende, em última instância, não do fato de o pesquisador/observador estar com o gravador, mas do grau de sinceridade, de confiança mútua, de afinidades, enfim de todos os aspectos que são desenvolvidos entre pesquisador e informantes.

Em um dado momento, o pesquisador passa a exercer, então, o papel de observador. Conforme sugere Silva (1991), 
é preciso esclarecer que a observação participante, para ser um procedimento válido e fidedigno de investigação, exige do pesquisador um planejamento e uma decisão quanto ao grau de observação e participação no contexto em que ocorre o fenômeno pesquisado. Isso equivale a determinar com antecedência "o quê" e "como" observar. (SILVA, 1991, p.50)

Sendo assim, o pesquisador deve-se posicionar quanto ao seu papel em relação ao grau de observação e participação no contexto pesquisado, pois, na pesquisa qualitativa, a observação pode ser utilizada com distintos graus de participação do pesquisador no campo em estudo. Segundo Angrosino (2009, p. 53), “a observação participante não é propriamente uma técnica de coletar dados, mas, sim, o papel adotado pelo etnógrafo para facilitar sua coleta de dados". Nessa forma de observação, o pesquisador possui um grau de interação com a situação estudada, afetando-a ou sendo afetado por ela (ANDRE, 1995, p. 28).

Conforme Junker (1971) e Silva (1991), há diferentes tipos de participantes no contexto pesquisado. Creswell (2010, p. 213) faz referência a quatro tipos de participantes: participante completo (o pesquisador oculta o papel, pois tem uma experiência de primeira mão com o participante); observador como participante (o papel do pesquisador é conhecido); participante como observador (o pesquisador não oculta sua identidade, revelando, porém, apenas parte do que pretende investigar para não provocar muitas alterações no comportamento do grupo estudado); e observador completo (o pesquisador observa sem participar).

Nesta pesquisa, exerço dois papéis diferenciados: o de observadora como participante, no Colégio Militar de Brasília, onde sou professora há 18 anos, bem como o de participante como observadora, na Unidade de Internação de Santa Maria, onde, como voluntária participei do projeto de leitura "Leitura - a arte do saber". ${ }^{12}$ A foto abaixo ilustra um evento concreto (CHOULIARAKI; FAIRCLOUGH, 1999, p. 21) de articulação entre interação e ação, como forma de internalizar traços de uma prática social.

\footnotetext{
${ }^{12}$ A convite da diretora da UISM, e com a autorização da juíza para a realização do trabalho de pesquisa de campo, a autora ministrou aulas de redação na referida instituição. A interação com cada jovem era individual, na biblioteca da Unidade de Internação, e sempre sob a guarda de um agente. Em atenção a um pedido meu, há dois adolescentes sentados à mesa tão somente por ocasião da foto.
} 


\section{Fotografia 3.1 - Momento de letramento na UISM}

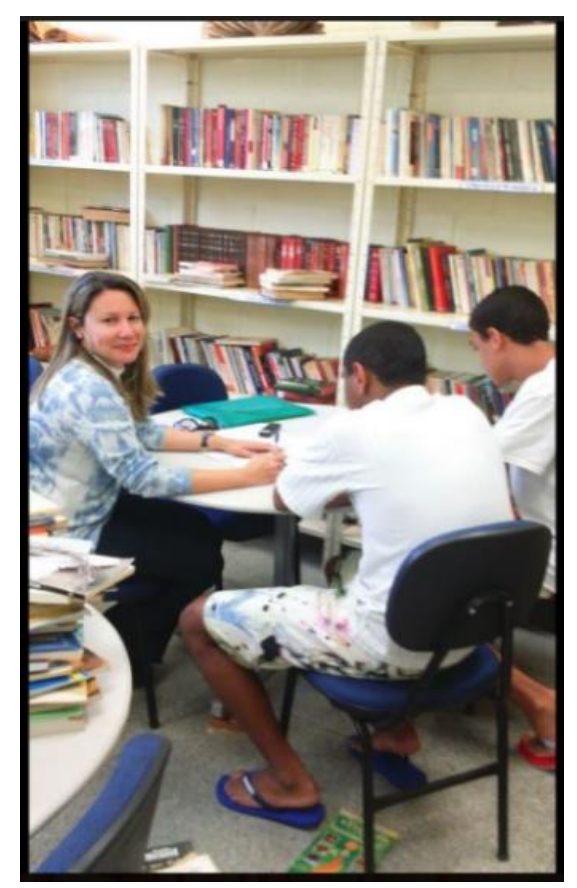

\subsubsection{NOTAS DE CAMPO}

As observações foram registradas em forma de notas de campo. Esse instrumento propiciou que fossem articulados diferentes métodos, bem como a percepção de diversos momentos com os colaboradores participantes. Quanto às notas de campo, Clifford (1993, p. 51) as subdivide em: inscrição, transcrição e descrição. Na inscrição, o pesquisador faz anotações de palavras-chave ou de notas mneumônicas que o auxiliarão no desenvolvimento posterior de notas mais aprimoradas. Na transcrição, o pesquisador anota as respostas dos participantes da pesquisa durante a pesquisa. Na descrição, nota de campo privilegiada por mim, nesta pesquisa, há uma reflexão do pesquisador sobre a realidade cultural analisada. Optei por fazer as anotações após as conversas e entrevistas para não prejudicar a interação com os participantes colaboradores.

A seguir, há um exemplo da forma como as notas de campo foram feitas.

A Pedagoga relatou a respeito das dificuldades enfrentadas por profissionais que atendem os socioeducandos, devido às diversas carências encontradas na UISM, seja pela falta de profissionais, seja pela falta de cursos profissionalizantes. Além disso, são observadas as próprias limitações do sistema socioeducativo. Tudo isso a deixa frustrada, porque ela não consegue executar, realmente, o trabalho que gostaria de praticar. Porém, apesar dessas limitações, quando atende os adolescentes, acredita na possibilidade de transformação do socioeducando, isto é, na saída dele do mundo da criminalidade. (Nota de campo registrada em 23/9/2014). 
Registrei essa nota de campo após entrevista feita com uma das pedagogas da UISM. Nesse dia, conversei com outras pedagogas, informalmente, na sala de uma delas, e todas que lá estavam relataram as dificuldades de desenvolver um trabalho contínuo e eficaz com os socioeducandos, devido a todas as carências do sistema socioeducativo.

\subsection{Unidade de Internação de Santa Maria e Colégio Militar de Brasília}

A Unidade de Internação de Santa Maria (UISM), inaugurada em 20 de março de 2014, é uma instituição que realiza atendimento socioeducativo de adolescentes do sexo masculino na faixa etária entre 12 a 18 anos em cumprimento de medida socioeducativa estrita; e de adolescentes do sexo feminino entre 12 e 18 anos em cumprimento de medida socioeducativa de internação estrita ou provisória. A internação provisória, que antecede a medida judicial, tem duração de até 45 (quarenta e cinco) dias, e a Medida Socioeducativa de Internação estrita é aplicada por tempo indeterminado, não superior a 3 (três) anos, conforme previsto nos artigos 108, 121 e 122 da Lei n 8.069/90 (Estatuto da Criança e do Adolescente de 1990).

O Colégio Militar de Brasília foi inaugurado em $1^{\text {o }}$ de setembro de 1978. Os Colégios Militares têm como objetivo a Educação Básica nos Ensinos Fundamental e Médio, são ministrados em consonância com a Legislação Federal da Educação Nacional e obedecem às leis e aos regulamentos em vigor no Exército, naquilo que lhes for cabível, em especial às normas e diretrizes do Departamento de Ensino e Pesquisa (DEP), órgão gestor da linha de ensino no Exército. É uma Instituição destinada à educação dos filhos de militares das três Forças Armadas e Forças Auxiliares, além de estudantes oriundos do meio civil que ingressam por meio de Concurso Público realizado anualmente nas cidades em que estão sediados os Colégios Militares.

\subsection{ABORDAGEM TEÓRICO-METODOLÓGICA}

As questões teóricas e os aspectos metodológicos que balizam esta pesquisa inseremse na Análise Crítica do Discurso e na Linguística Sistêmico-Funcional. Vale ressaltar que a ADC é uma forma de pesquisa social que tem um olhar para o uso da linguagem nas instituições sociais, para o poder, em suas relações assimétricas, bem como para situações opressoras que podem ser mudadas ou transformadas; a LSF, por sua vez, "conecta a 
linguística às práticas sociais em seus contextos de cultura e de situação e propicia a consciência dos gêneros do discurso e seus propósitos nos diversos domínios sociais" (SILVA, 2010, p. 62). Posto isso, descrevo essas duas abordagens, enquanto ferramentas teórico-metodológicas, para aproximar discurso e gramática, na medida em que a gramática é flexível e se molda, conforme lembra Neves (2002, p. 173) “por acomodação" e "por pressões comunicativas", ou seja, por pressões discursivas.

\subsubsection{Abordagem teórico-metodológica da ADC}

A Análise de Discurso Crítica concebe a língua como prática social (FAIRCLOUGH, 1992) e é vista não só como corrente linguística, mas, principalmente, como método de estudo (SILVA, 2005, p. 37). Nessa perspectiva, saliento que sigo a proposta metodológica da Análise de Discurso Crítica que, na reconhecida função de método de análise, insere-se em um campo de estudo no qual o pesquisador busca investigar o envolvimento da linguagem na vida social, cujo sistema aberto é formado por práticas. Observe-se que, aqui, há o "propósito explícito de contribuir para uma mudança social específica em favor dos grupos dominados”, como observa van Dijk (2008, p. 16), almejando-se formas de contribuições na tentativa da reintegração de adolescentes reclusos que sairão da instituição e irão viver e conviver em sociedade.

Em vista disso, adaptei os pressupostos metodológicos da ADC, desenvolvidos como um arcabouço teórico-metodológico, apresentados por Chouliaraki e Fairclough (1999, p. 60) à minha pesquisa. Essa adaptação tem como finalidade a feitura de uma análise de discurso crítica (na dimensão da exterioridade da linguagem) das representações linguístico-discursivas de adolescentes.

Esse modelo de análise proposto por Chouliaraki e Fairclough (1999), baseado na crítica explanatória de Bhaskar $(1998 ; 2002)$ sugere cinco etapas:

1) identificação do problema;

2) obstáculos a serem enfrentados;

3) função do problema na prática;

4) possíveis maneiras de superar os obstáculos;

5) reflexão da análise. 
1 a etapa: percepção de um problema social

Com o propósito de focalizar um erro socialmente agravante, qual seja, a ineficácia do sistema socioeducativo, em termos de reinserção social do adolescente, busco aproximar duas instituições, relativamente distantes, mas que têm em comum a disciplina em suas práticas sociais, dentro de um mesmo plano de estudo voltado para os níveis linguístico e discursivo, a fim de descobrir lacunas existentes em Documentos Oficiais relativos a adolescentes, principalmente, no que se refere às formas discursivas de representação.

$2^{\text {a }}$ etapa: obstáculos a serem superados:

a) Análise da conjuntura: a conjuntura, para os autores, representa um caminho particular de uma rede de práticas que constituem as estruturas sociais.

Analisar a conjuntura da situação dos adolescentes nas duas instituições.

b) Análise de práticas particulares:

Analisar as representações linguístico-discursivas voltadas para adolescentes nos Documentos Oficiais.

(i) Práticas relevantes

Relacionar os discursos institucionalizados aos discursos dos socioeducandos.

(ii) Relações do discurso com outros momentos da prática

Relacionar a realidade de adolescentes aos discursos disciplinadores das duas Instituições (discursos institucionalizados).

c) Análise do discurso

(i) Análise estrutural: a ordem do discurso

Analisar a ordem do discurso legal e institucional.

(ii) Análise interacional

Análise da representação de adolescentes embasada nas categorias da ADC e LSF.

$3^{\text {a }}$ etapa: função do problema na prática:

Investigar se os discursos disciplinadores dos Regimentos Internos das duas instituições são ou não postos em prática, como forma de (sócio)educação. 
$4^{\text {a }}$ etapa: possíveis maneiras de superar obstáculos:

Apontar caminhos, por meio da língua como prática social (discurso) que permitam minimizar, ou, em condições propícias, transformar práticas discursivas que revertam a situação de reincidência dos adolescentes nos delitos e nas Unidades de Internação.

5 etapa: reflexão sobre a análise:

d) Identificar e, em condições propícias, apontar práticas sociais transformadoras no âmbito educacional e institucional, por meio da língua como prática social (discurso), voltadas para a adolescência desamparada e em situação de relativa (des)proteção do Estado, ou seja, os socioeducandos.

Essas etapas são importantes para a elaboração e construção da pesquisa, pois a ADC é uma prática teórico-metodológico-crítica e constitui uma forma de pesquisa social. Isso, porque há uma relação interna e dialética entre linguagem e sociedade.

Ademais, desenvolve o estudo da linguagem como prática social, com vistas à investigação de transformações na vida social contemporânea (FAIRCLOUGH; 2001). Esse envolvimento da linguagem na vida social contribui para que linguistas debatam e façam questionamentos a respeito de temas ligados ao racismo, à discriminação, ao controle e à manipulação institucional, à identidade nacional, à identidade de gênero, à violência, à exclusão social, o que acarreta na tentativa operar uma mudança social, a partir da observação e análise desses problemas.

\subsubsection{Abordagem teórico-metodológica da LSF}

A LSF oferece instrumentos que permitem investigar a linguagem segundo a situação em que ela é produzida e entendê-la a partir da função para a qual está sendo produzida tendo em vista quem a produz e para quem, quando, onde, e como a produz. Dessa forma, é uma proposta teórico-metodológica que serve de instrumento de trabalho ao analista (BARBARA; MACÊDO, 2009). Esses instrumentos tornam-se ferramentas para codificar, descrever, mapear a língua e a linguagem em uma gama de significados no sistema léxico-gramatical da língua. De acordo com Silva (2006), enfocar o discurso como prática social equivale: 
investigar os processos pelos quais a língua passa, moldando uma realidade e sendo por esta moldada. Por esta razão se afirma que um sistema linguístico não é neutro, uma vez que os discursos nele veiculados podem refletir, de algum modo, posições ideológicas e costumes. Até mesmo a forma particular do sistema gramatical de uma língua encontra-se intimamente relacionada com as necessidades pessoais e sociais que a linguagem tem de satisfazer, o que se espelha na criatividade do falante. Daí a necessidade de buscar uma síntese entre estudos de forma e função. (SILVA, 2006, p. 166)

Sendo assim, a LSF fornece subsídios para a interpretação da estrutura gramatical no que concerne à avaliação dos significados em seus termos potenciais a partir de análises das escolhas feitas para a composição de um texto em um dado contexto. Segundo essa noção, os falantes operam escolhas em função daquilo que querem comunicar nas situações particulares em que se encontram. O resultado dessas escolhas é o texto, que surge assim como uma instanciação do sistema, já que esse sistema é instanciado sob a forma de textos (HALLIDAY; MATTHIESSEN, 2004, p. 26). Ressalte-se, porém, que o objeto do analista são os textos por serem esses textos instanciações contextuais do sistema, que podem desempenhar simultaneamente as três metafunções básicas: a produção de significados ideacionais, interpessoais e textuais. Nesta pesquisa, a LSF é o meio ferramental utilizado para análise da dimensão do interior da linguagem, com enfoque nas metafunções ideacional e interpessoal da linguagem.

Para a análise detalhada do estudo dos aspectos da composição lexical, da temática dos textos selecionados, bem como da análise do sistema de transitividade da Gramática Sistêmico-Funcional, conforme a proposta de Halliday \& Matthiessen (2004), foi utilizado o programa WordSmith Tools. Essa ferramenta, nesta pesquisa, é utilizada como subsídio de análise da dimensão interior da linguagem, a partir do estudo da relação entre os processos de transitividade (Gramática da Experiência) e outros elementos e aspectos da vida social.

\subsection{USO DO PROGRAMA WORDSMITH TOOLS}

O uso de novas tecnologias tem revolucionado mudanças nos padrões operacionais da pesquisa qualitativa. Recursos computacionais têm sido criados para auxiliar na análise de grandes volumes de materiais qualitativos. Um dos programas desenvolvidos é o WordSmith Tools que oferece algumas ferramentas para ajudar o analista a examinar características e relações do texto em sua análise linguística. O WordSmith Tools foi elaborado por Mike Scott e publicado pela Oxford University Press. Trata-se de um programa que coloca à disposição do analista uma série de recursos, os quais propiciam a análise de vários aspectos da 
linguagem. Dentre esses aspectos, estão a composição lexical, a temática de textos selecionados, e a organização retórica e composicional de gêneros discursivos.

O WordSmith Tools é composto de três ferramentas principais, segundo Berber Sardinha (1999):

WordList: ferramenta que propicia a feitura de listas de palavras. Assim, para cada vez que o WordList é chamado para fazer uma lista de palavras, três janelas são produzidas: uma que contém uma lista de palavras ordenada por ordem alfabética, outra com uma lista classificada pela frequência das palavras, e uma terceira janela com estatísticas simples a respeito dos dados.

KeyWords: ferramenta que permite a seleção de itens de uma lista de palavras (ou mais) por meio da comparação de suas frequências com uma lista de referências. KeyWords contrasta uma lista de palavras (ou mais de uma) de um corpus de estudo com uma lista de palavras de um corpus de referência. O resultado do contraste é uma lista de palavras chave, ou palavras cujas frequências são estatisticamente diferentes no corpus de estudo e no corpus de referência.

Concord (Concordanciador): ferramenta que produz concordâncias, ou listagens das ocorrências de um item específico (chamado palavra de busca ou nódulo, que pode ser formado por uma ou mais palavras) acompanhado do texto ao seu redor (o co-texto).

Nesta pesquisa, o programa WordSmith Tools é utilizado como um recurso ao analisarmos a ocorrência dos processos e sua interligação com os participantes e circunstâncias que fazem parte dos textos do corpora, o que evoca, nesse momento, a análise quantitativa, para mostrar a representação lexical do termo adolescente nos Documentos Oficiais, bem como o sistema de Transitividade nos Regimentos Internos dos Colégios Militares e das Unidades de Internação. Os dados gerados e selecionados a partir do uso dessa ferramenta também serão analisados à luz da ADC e da LSF. Portanto, as dimensões do processo de pesquisa, citadas acima, contribuirão para investigar as representações de atores sociais frente aos discursos que estão na Constituição Federativa do Brasil, no ECA e nos Regimentos Internos das Unidades e do CMB. 


\section{Algumas considerações}

\section{Figura 3.1 - A leitura como libertação}

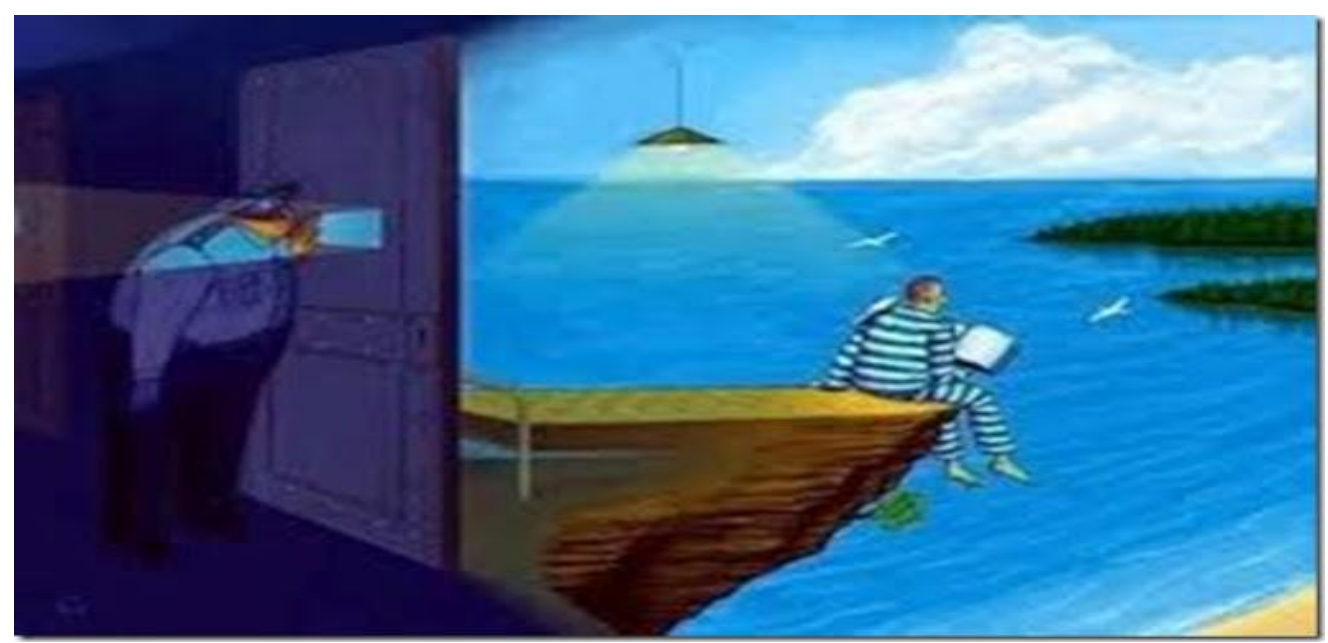

Fonte: www.lpm.com.br

Este capítulo tratou da caracterização da pesquisa, assim como dos procedimentos teórico-metodológicos utilizados na concepção e no desenvolvimento desta pesquisa. Escolhi a metodologia qualitativa, pois esse tipo de abordagem possibilita a interpretação da realidade de um fato social. Este estudo envolve dados documentais e dados de natureza etnográfica. Dessarte, faço uso dessa abordagem, porque o foco, nesta tese, é discutir, à luz da Análise de Discurso Crítica e da Linguística Sistêmico-Funcional, as representações sociais linguísticodiscursivas voltadas para adolescentes registradas nos Regimentos Internos de suas respectivas instituições, no intuito de identificar como esses adolescentes são representados e como se representam. Para tanto, foram selecionados dois regimentos, com o objetivo de discutir, à luz da Análise de Discurso Crítica e da Linguística Sistêmico-Funcional, as representações linguístico-discursivas voltadas para adolescentes com base nos Regimentos Internos de instituições públicas, bem como seus desdobramentos balizados em leis. Trata-se do Regimento dos Colégios Militares, Regimento Interno das Unidades de Internação, Estatuto da Criança e do Adolescente e a Constituição Federal do Brasil de 1988. Os dados empíricos de natureza etnográfica foram gerados junto a adolescentes do Colégio Militar de Brasília e da Unidade de Internação de Santa Maria - DF.

Os métodos utilizados na geração de dados de natureza etnográfica foram a observação participante, as notas de campo e as entrevistas. Esses dados foram colhidos entre os anos de 2014 a 2016, junto a adolescentes de 12 a 18 anos, estudantes do Colégio Militar 
de Brasília e socioeducandos da Unidade de Internação de Santa Maria. Nesta pesquisa, exerço dois papéis diferenciados: o de observadora como participante, no Colégio Militar de Brasília, onde sou professora há 18 anos e o de participante como observadora, na Unidade de Internação de Santa Maria, onde, como voluntária, participei do projeto de leitura "Leitura - a arte do saber". Observei que a leitura, para os socioeducandos, é uma forma de liberdade, como ilustra a Figura 3.1, acima, pois eles, sem sair das celas, conseguem conhecer novas histórias, novos lugares e situações diferentes da realidade de vida que eles tiveram e, agora apreendidos, têm. Dessa forma, em um determinado momento, enquanto se ocupam com a leitura, não ficam ociosos, pensando em fugas, ou mesmo, em outros delitos que cometerão quando saírem da Unidade de Internação. Esse conhecimento e o gosto adquirido pela leitura podem ser considerados como ferramentas para a (re)educação dos adolescentes que estão em situação de reclusão.

Nessa esteira, ressalte-se que esta tese tem o propósito de colaborar para uma mudança social específica em favor de grupos marginalizados, com a contribuição almejada da reintegração e reeducação social de socioeducandos que sairão das Unidades de Internação e irão viver e conviver em sociedade.

Cabe destacar, aqui, que já foram desenvolvidas relevantes pesquisas na área de Linguística, na Universidade de Brasília, referentes a análises linguístico-discursivas de Documentos Oficiais concernentes a crianças e adolescentes, bem como narrações e/ou relatos de adolescentes que estão em situação de reclusão e em situação de vulnerabilidade social. Esses trabalhos são importantes, pois apontam para graves problemas nas práticas sociais de crianças, adolescentes e jovens. Dentre eles, encontram-se o de Lopes (2003), Resende (2008), Martins (2012), Moreira (2013), Campêlo (2014), Moreira (2015), Silva $(2015,2011,2009)$.

No próximo capítulo, serão feitas análises de excertos do ECA, da Constituição e análises comparativas de excertos dos Regimentos internos das duas Instituições. 


\section{CAPÍTULO 4 - REPRESENTAÇÃO DOS ADOLESCENTES COMO OBJETO DO DISCURSO}

A dignidade da pessoa humana é um valor espiritual e moral inerente à pessoa humana, que se manifesta singularmente na autodeterminação consciente e responsável da própria vida e que traz consigo a pretensão ao respeito por parte das demais pessoas, constituindo-se em um mínimo invulnerável que todo estatuto jurídico deve assegurar, de modo que apenas excepcionalmente possam ser feitas limitações ao exercício dos direitos fundamentais, mas, sempre sem menosprezar a necessária estima que merecem todas as pessoas enquanto seres humanos. (MORAES, 2000, p. 6061)

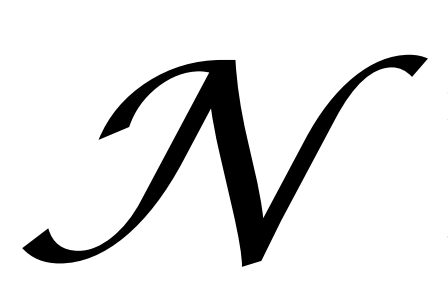

este capítulo, apresento o corpus documental constituído pelo Regimento Interno dos Colégios Militares, pelo Regimento Interno do Colégio Militar de Brasília, pelo Regimento Interno das Unidades de Internação, pelo Regimento Interno da Unidade de Internação de Santa Maria e pelo Estatuto da Criança e do Adolescente. A primeira seção consiste em um estudo da representação lexical dos adolescentes desde o Código de Menores Mello Matos até os referidos Regimentos Internos dos Colégios Militares e das Unidades de Internação. Na segunda seção, serão apresentadas, utilizando-se a ferramenta WordSmith Tools, as formas mais recorrentes de representação do adolescente em documentos oficiais. Nessa perspectiva, será feita uma análise do gênero textual Regimento como ação social. Na quarta seção, sob a lupa do WordSmith Tools, serão apontados os componentes da transitividade de ambos os regimentos. Já a quinta seção, é dedicada à análise documental dos regimentos na vertente da Linguística Sistêmico-Funcional e da Análise de Discurso Crítica. Na sexta seção, será feita, à luz dos pensamentos de Foucault, uma comparação das medidas disciplinares executadas pelas duas Instituições e serão apontados os modos operacionais propostos por Thompson nos Regimentos Internos. Por fim, serão apresentadas algumas considerações pertinentes ao capítulo.

\subsection{REPRESENTAÇÃO LEXICAL DOS ADOLESCENTES}

Os documentos selecionados para esta pesquisa, o Regimento Interno dos Colégios Militares, o Regimento Interno do Colégio Militar de Brasília, o Regimento Interno das Unidades de Internação, o Regimento Interno da Unidade de Internação de Santa Maria e o Estatuto da Criança e do Adolescente, estão interconectados entre si, na medida em que todos 
têm como tema o adolescente, seja representado como socioeducando ou adolescente em situação de reclusão, seja representado como estudante ou aluno. Nas palavras de Fairclough (2003, p. 25), “a representação é uma questão claramente discursiva e é possível distinguir diferentes discursos que podem representar a mesma área do mundo de diferentes perspectivas ou posições".

No que concerne à referência a adolescentes, sujeitos de direitos pela legislação em vigor no Brasil, o termo "adolescente" - nas leis e regimentos abordados, como o Código de Menores, a Constituição Federal de 1988, o Estatuto da Criança e do Adolescente de 1990, os regimentos dos Colégios Militares e das Unidades de Internação - costuma associar-se a várias formas de registro, tais como menor, aluno(s), aluno-destaque, discente, estudante(s), socioeducando(s), educando(s). Neste viés, cabe lembrar que a linguagem, na visão sistêmicofuncional, é concebida como um sistema de escolhas baseado na gramática, caracterizada pela organização em estratos e pela diversidade funcional. O sentido é, entretanto, não somente a escolha dos termos, mas a posição em que são colocados e ligados a outras expressões.

Essa caracterização ocorre de acordo com o (co)texto em que os termos costumam ser empregados nos respectivos regimentos. Conforme Fairclough (2003), discursos podem ser diferenciados pelo modo particular de lexicalizar o mundo, não só o material, mas sobretudo as relações sociais e as ideologias. Nessa perspectiva, enfatiza o autor (FAIRCLOUGH, 2003, p. 129), que os mais óbvios traços de distinção de um discurso parecem ser traços de vocabulário - discursos 'nomeiam' ou 'lexicalizam' o mundo de modos particulares. Entretanto, mais do que focar em diferentes modos de lexicalização dos mesmos aspectos do mundo, torna-se necessário focar, também, na maneira pela qual diferentes discursos estruturam o mundo.

Sendo assim, faz-se, aqui, um percurso linguístico-discursivo por documentos de diferentes épocas para apresentar as formas de representação, configuradas linguisticamente, do adolescente, enquanto objeto de discurso. Observe-se que, neste trabalho, norteio-me pelo artigo $2^{\circ}$ do Estatuto da Criança e do Adolescente, o qual assegura que é adolescente aquele pertencente à faixa etária entre 12 e 18 anos de idade, faixa etária que faz parte do corpus deste trabalho. Cabe ressaltar que foi necessária a criação dessa diferenciação no ECA entre criança e adolescente, segundo Ishida (2013, p. 7), em virtude da urgência da regulamentação de alguns institutos, como a aplicação de medida socioeducativa ou mesmo a necessidade de autorização de viagem. Vejamos. 
(14) Art. $2^{\circ}$ Considera-se criança, para os efeitos desta Lei, a pessoa até doze anos de idade incompletos, e adolescente aquela entre doze e dezoito anos de idade.

(ECA, Livro I - Parte Geral, Título I - Das Disposições Preliminares)

(15) Parágrafo único. Nos casos expressos em lei, aplica-se excepcionalmente este Estatuto às pessoas entre dezoito e vinte e um anos de idade.

(ECA, Livro I - Parte Geral, Título I - Das Disposições Preliminares)

Os dispositivos dos excertos (14) e (15) conceituam, de forma objetiva, quem é considerado criança e quem é considerado adolescente, para fins de incidência das disposições que estão no ECA. Criança e adolescente, em diferentes situações, recebem tratamento diferenciado para ambas as categorias, como é o caso do disposto nos artigos $45, \S 2^{\circ}$ e 105 , do ECA, como se pode observar abaixo.

(16) Art. 45. A adoção depende do consentimento dos pais ou do representante legal do adotando.

$\S 1^{o}$. O consentimento será dispensado em relação à criança ou adolescente cujos pais sejam desconhecidos ou tenham sido destituídos do pátrio poder.

$\S 2^{\circ}$. Em se tratando de adotando maior de doze anos de idade, será também necessário o seu consentimento.

(ECA, Livro I, Parte Geral, Título II - Dos Direitos Fundamentais, Capítulo III - Do Direito À Convivência Familiar E Comunitária, Seção III - Da Família Substituta, Subseção IV -

Da Adoção)

(17) Art. 105. Ao ato infracional praticado por criança corresponderão às medidas previstas no art. 101.

(ECA, Livro II, Parte Especial, Título III - Da Prática De Ato Infracional)

Os excertos (16) e (17) fazem menção à criança e ao adolescente de formas diferentes. Em (16), o adolescente deverá expressar sua própria opinião em relação à sua adoção; já em (17), não serão aplicadas as medidas socioeducativas para as crianças e, sim, as de proteção. Fica registrada legalmente e especificamente a diferença técnica entre criança e adolescente e o tratamento direcionado a cada um.

O termo adolescente, em sua concepção moderna, surgiu entre o final do século XVII e início do século XIX. O que se caracterizava apenas como um período da vida humana, entre infância e vida adulta, com o passar dos anos passou a adquirir uma conotação associada 
à ideia de crise, problemas, rebeldia, variações de humor, mudanças hormonais, crescimento físico, psicossocial e delinquência.

Cabe observar que, no ECA, o legislador, como já havia feito o constituinte, quando foi promulgado o artigo 227, de nossa Carta Magna, não utilizou, propositalmente, o termo menor, em referência a adolescentes. Derivado do latim minor, na gramática normativa, é um adjetivo comparativo. Já no sentido técnico-jurídico, empregado como substantivo, designa a pessoa que não atingiu a maioridade, ou seja, não atingiu a idade legal para que se considere maior e capaz. Menor, nessa vertente, pode ser entendido como a pessoa que não tem a idade completa, exigida por lei, para ser considerada capaz, isto é, maior. Daí derivam a menoridade e a maioridade. Entretanto, esse termo também possui, referindo-se à criança e ao adolescente, uma conotação pejorativa, discriminatória e uma rotulação de alguém pertencente a uma classe social de baixa renda, abandonado pela família, estigmatizado à ideia de infrator e "bandido". O conceito de menoridade, então, torna-se vinculado não somente à idade, mas também à marginalidade, considerada tanto nas situações de abandono, como também nas de delito.

Nessa concepção, parece tratar-se de uma visão dicotômica. Isso, porque a pessoa com menos de 18 anos que não possuía família, poder aquisitivo ou educação era (e ainda o é) considerada menor. Já a criança, a moça, o rapaz, o mancebo e o jovem, eram aqueles que frequentavam bons ambientes, que tinham família estruturada e com boas condições financeiras, estudavam em uma boa escola e que tinham dinâmicas coletivas sadias. Essa visão simplista remete à categoria do estranho, que, segundo Baumann (1998), refere-se aos que não se encaixam no mapa cognitivo, moral e estético do mundo. Na sociedade dos consumidores, então, os pobres e os que não têm acesso à educação são os estranhos.

Cada vez mais, ser pobre é encarado como um crime; empobrecer como um produto de predisposições ou intenções criminosas - abuso de álcool, jogos de azar, vadiagem, vagabundagem. Os pobres longe de fazer jus a cuidado e assistência, merecem ódio e condenação - como a própria encarnação do pecado. (BAUMAN, 1998, p.59)

A noção de menor, nesse caso, é incompatível com a nova orientação jurídicoconstitucional, que procura evitar a rotulação do termo lexical menor como aquele que é um "marginal", ou seja, que reproduz o conceito estigmatizante e discriminatório remetido ao extinto Código de Menores. Porém, cabe observar que, apesar de a Constituição Federal de 1988, em seu art. $5^{\circ}$, pregar que todos são iguais perante a Lei, ainda há quem considere 
crianças e adolescentes como "menores", por se tratarem de sujeitos abandonados, com vulnerabilidade social, termo invocado em um campo lexical preconceituoso e estereotipado.

A propósito, a primeira legislação voltada para a criança e o adolescente no Brasil, tendo vigorado até a promulgação do Estatuto da Criança e do Adolescente, no ano de 1990, foi O Código de Menores de $1927^{13}$, conhecido como "Código de Menores Mello Matos". ${ }^{4}$ Tinha como objetivos basilares a coibição dos atos dos chamados "delinquentes juvenis", bem como o tratamento, por meio de medidas assistencialistas, de pedagogia corretiva e de proteção, às crianças e aos adolescentes com até 18 anos de idade em situação de abandono ou órfãs. Daí surge, em termos legais, a concepção de correção voltada para crianças e adolescentes, nomeados legalmente por menores abandonados. Eram designados dessa forma pela ausência da família ou porque a família não tinha condições de cuidar da criança ou do adolescente. Eram também chamados, em determinados casos, de menores delinquentes. Essas crianças e adolescentes eram encaminhadas para abrigos, como o da fotografia apresentada a seguir.

Figura 4.1 - Asilo de Menores Abandonados ${ }^{15}$

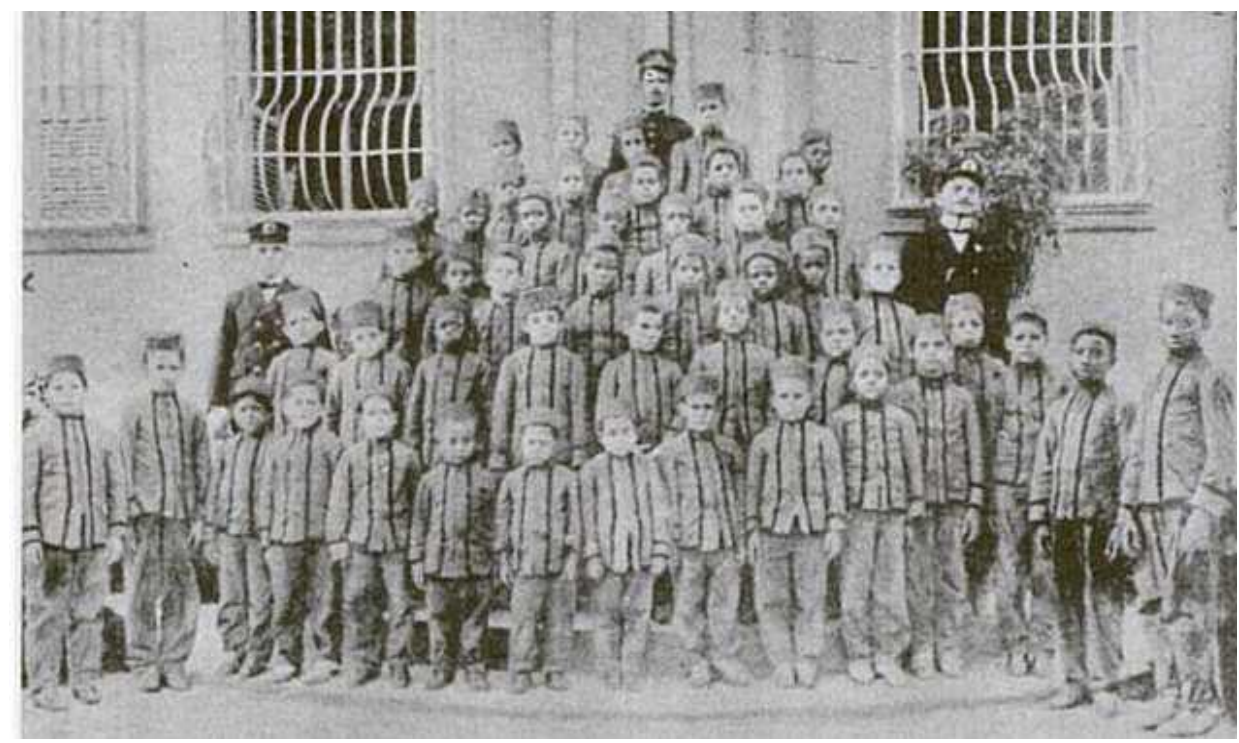

Fonte: Rizzini; Rizzini (2004, p. 19) $)^{16}$

13 Decreto número 17.943-A de 12 de outubro de 1927/ Lei disponível em <http://www.planalto.gov.br/ccivil_03/decreto/1910-1929/d17943a.htm>

${ }^{14}$ O Código de Menores Mello Matos foi uma homenagem a seu autor, o jurista José Cândido de Albuquerque Mello Mattos, primeiro juiz de adolescentes do país e de mais longa permanência, de 1924 até o ano de seu falecimento, em 1934.

15 Asilo de Menores Abandonados (Rio de Janeiro, 1907), criado pelo chefe da polícia carioca, Alfredo Pinto Vieira de Mello, em 1907, para o abrigo de crianças recolhidas nas ruas do Rio de Janeiro. Administrado pela polícia até 1915, quando foi integrado ao Patronato de Menores (particular), devido à má administração. As penas disciplinares infligidas aos menores eram "excessivas e desumanas", segundo relato de Ataulpho de Paiva, em Justiça e assistência, 1916. Passou, então, a ter a denominação de "Casa de Preservação". 
A Figura 4.1 representa como era o abrigo de crianças e adolescentes recolhidas nas ruas do Rio de Janeiro. No Código de Menores de 1927, eram nomeadas Infantes expostos as crianças, em situação de abandono ou órfãs, de dois a sete anos. Já aqueles que se encontravam na mesma situação, com idade entre sete e dezoito anos, eram chamados de abandonados, vadios, mendigos e libertinos. Vejamos.

(18) Art. 26. Consideram-se abandonados os menores de 18 anos:

I - que não tenham habitação certa, nem meios de subsistência, por serem seus pais falecidos, desaparecidos ou desconhecidos, ou por não terem tutor ou pessoa sob cuja guarda vivam;

II - que se encontrem eventualmente sem habitação certa, nem meios de subsistência, devido à indigência, enfermidade, ausência ou prisão dos pais, tutor ou pessoa encarregada de sua guarda;

III - que tenham pai, mãe ou tutor encarregado de sua guarda reconhecidamente impossibilitado ou incapaz de cumprir os seus deveres para com o filho ou pupilo ou protegido;

IV - que vivem em companhia de pai, mãe, tutor ou pessoas que se entreguem habitualmente à prática de atos contrários à moral e bons costumes;

$V$ - que se encontrem em estado habitual da vadiagem, mendicidade ou libertinagem;

$V I$ - que se frequentem lugares de jogo ou de moralidade duvidosa, ou andem na companhia de gente viciosa ou de má vida;

VII - que, devido à crueldade, abuso de autoridade, negligência ou exploração dos pais, tutor ou encarregado de sua guarda, sejam: a) vítimas de maus tratos físicos habituais ou castigos imoderados; b) privados habitualmente dos alimentos ou dos cuidados indispensáveis à saúde. c) empregados em ocupações proibidas ou manifestamente contrárias à moral e aos bons costumes, ou que lhes ponham em risco a vida ou a saúde; d) excitados habitualmente para a gatunice, mendicidade ou libertinagem;

VIII - que tenham pai, mãe ou tutor, ou pessoa encarregada de sua guarda, condenado por sentença irrecorrível; a) a mais de dois anos de prisão por qualquer crime; b) a qualquer pena como co-autor, cúmplice, encobridor ou receptor de crime cometido por filho, pupilo ou menor sob sua guarda, ou por crime contra estes.

(Código de Menores Mello Matos, 1927)

No excerto (18), os menores abandonados eram assim representados devido à situação de vulnerabilidade social em que viviam. A situação de abandono parecia estar também atrelada à questão de moral e de bons costumes. Dessa forma, a representação dos menores e abandonados vem em forma de pobreza, o que denota um modo de exclusão social, de diferenças entre ricos e pobres, bom e ruim, bem e mal.

(19) Art. 28. São vadios os menores que:

a) vivem em casa dos pais ou tutor ou guarda, porém se mostram refratários a receber instrução ou entregar-se a trabalho sério e útil, vagando habitualmente pelas ruas e logradouros públicos;

${ }^{16}$ A fotografia do Asilo de Menores Abandonados foi encontrada por Rizzini e Rizzini, nos arquivos de Assistência à Infância, IPAI, de 1907, no Rio de Janeiro. 
b) tendo deixado sem causa legítima o domicílio do pai, mãe ou tutor ou guarda, ou os lugares onde se achavam colocados por aquele cuja autoridade estavam submetidos ou confiados, ou não tendo domicílio nem alguém por si, são encontrados habitualmente a vagar pelas ruas ou logradouros públicos, sem que tenham meio de vida regular, ou tirando seus recursos de ocupação imoral ou proibida.

(Código de Menores Mello Matos, 1927)

(20) Art. 29. São mendigos os menores que habitualmente pedem esmola para si ou para outrem, ainda que este seja seu pai ou sua mãe, ou pedem donativo sob pretexto de venda ou oferecimento de objetos.

(Código de Menores Mello Matos, 1927)

(21) Art. 30. São libertinos os menores que habitualmente:

a) na via pública perseguem ou convidam companheiros ou transeuntes para a prática de atos obscenos;

b) se entregam à prostituição em seu próprio domicílio, ou vivem em casa de prostituta, ou frequentam casa de tolerância, para praticar atos obscenos;

c) forem encontrados em qualquer casa, ou lugar não destinado à prostituição, praticando atos obscenos com outrem;

d) vivem da prostituição de outrem.

(Código de Menores Mello Matos, 1927)

Nos excertos (19), (20) e (21), são apresentadas três formas de representação dos adolescentes, em situação de vulnerabilidade, no Código de Menores de 1927: vadios, mendigos e libertinos. Percebe-se que, nos três artigos acima, as crianças e os adolescentes em situação de vulnerabilidade e pobreza são considerados perigosos, marginais e pervertidos. A esse enfoque, cabe destacar Bakhtin (1979, p. 66), para quem "cada palavra se apresenta como uma arena em miniatura onde se cruzam e lutam valores sociais e se revela, no momento de sua expressão, como produto da intervenção viva das forças sociais", o que pode acarretar práticas de linguagem se constituindo em práticas sociais. Nessa direção, Rizzini (1997) argumenta a respeito do discurso utilizado em relação ao documento referente à criança no Código de Menores:

O discurso apresenta-se, com frequência, ambíguo, onde a criança deve ser protegida, mas também contida, a fim de que não cause danos à sociedade. Esta ambiguidade na defesa da criança e da sociedade guarda relação com uma certa percepção de infância, claramente expressa nos documentos da época - ora em perigo, ora perigosa. Tais representações não por acaso estavam associadas a determinados estratos sociais, sendo a periculosidade invariavelmente atrelada à infância das classes populares (RIZZINI, 1997, p. $34)$. 
Em 1940, criou-se o Código Penal de 1940 (Decreto-Lei no. 2.848, de 07 de dezembro de 1940), o qual se referia ao adolescente com menos de 18 anos como imaturo, em sua exposição de motivos. No ano de 1941, foi criado o Serviço de Assistência ao Menor (SAM), diretamente subordinado ao Ministério da Justiça e Negócios do Interior e articulado com o Juizado de Menores, em razão do Decreto número 3.799, que atribuía ao Estado poder para atuar junto às crianças e aos adolescentes, chamados de desvalidos e delinquentes. Esse sistema previa atendimento diferenciado para o adolescente que cometia infrações e para o adolescente carente e abandonado pela família, de modo que este era atendido em patronatos agrícolas e escolas de aprendizagem; já aquele, em reformatórios ou casas de correção.

Conforme Rizzini e Rizzini (2004, p. 31-32) lembram, os delinquentes eram apreendidos, contra a sua vontade; já os desvalidos, em boa parte, eram internados por solicitação da família, e até mesmo por iniciativa própria. Em 1979, o "Código de Menores Mello Mattos" foi reformulado pela Lei 6.697 de 1979 e visava à intervenção, por meio dos juizados de menores, dos adolescentes menores de 18 anos em desacordo com a lei, os então denominados abandonados. Esse Código vislumbrou o ajuste do adolescente ao meio social e trouxe um dispositivo de intervenção do Estado sobre a família, viabilizando a política dos internatos-prisão. Nesse documento, os adolescentes passaram a ser representados como menores em situação irregular. Essa representação concebia crianças e adolescentes como menores ou em situação irregular, porque, por meio da doutrina, "viam-se meninos e meninas não aquilo que eram (seres regulares), mas aquilo que não eram (seres irregulares). Não eram capazes, não eram sujeitos de direitos e deveres, não eram autônomos em relação aos seus pais ou em relação ao Estado" (SÊDA, 1998, p. 12).

Em 1988, promulgou-se a Constituição Federal, como resultado do processo de redemocratização, com significativos avanços, rompendo com paradigmas anteriores referentes às representações e aos direitos das crianças e dos adolescentes. O termo menor foi extinto da Constituição de 1988, bem como da Lei n. 8.069, que dispõe sobre o Estatuto da Criança e do Adolescente. Porém, registra-se que esse termo, embora muitas vezes empregado de maneira imprópria, discriminatória e distorcida, continua a ser utilizado, por desconhecimento ou propositalmente, de forma pejorativa ou não, em jornais escritos e telejornais, bem como em outros Diplomas Legais, conforme pode ser observado na Consolidação das Leis Trabalhistas (CLT) e no Código Civil (CC), como sinalizam os excertos (22) e (23) e o Lide do jornal Extra (24) abaixo. 
(22) Art. 405 - Ao menor não será permitido o trabalho:

I - nos locais e serviços perigosos ou insalubres, constantes de quadro para esse fim aprovado pela Secretaria de Segurança e Medicina do Trabalho;

II - em locais ou serviços prejudiciais à sua moralidade.

(Consolidação das Leis Trabalhistas, Capítulo IV, Da Proteção Do

Trabalho Do Menor, Seção I, Disposições Gerais)

(23) Parágrafo único. Cessará, para os menores, a incapacidade:

I - pela concessão dos pais, ou de um deles na falta do outro, mediante instrumento público, independentemente de homologação judicial, ou por sentença do juiz, ouvido o tutor, se o menor tiver dezesseis anos completos;

II - pelo casamento;

III - pelo exercício de emprego público efetivo;

$I V$ - pela colação de grau em curso de ensino superior;

$V$ - pelo estabelecimento civil ou comercial, ou pela existência de relação de emprego, desde que, em função deles, o menor com dezesseis anos completos tenha economia própria.

(Código Civil, Parte Geral, Livro I - Das Pessoas, Título I - Das

Pessoas Naturais, Capítulo I - Da Personalidade e Da Capacidade)

(24) Capa do jornal Extra ${ }^{17}$

Figura 4.2 - Capa do Jornal Extra

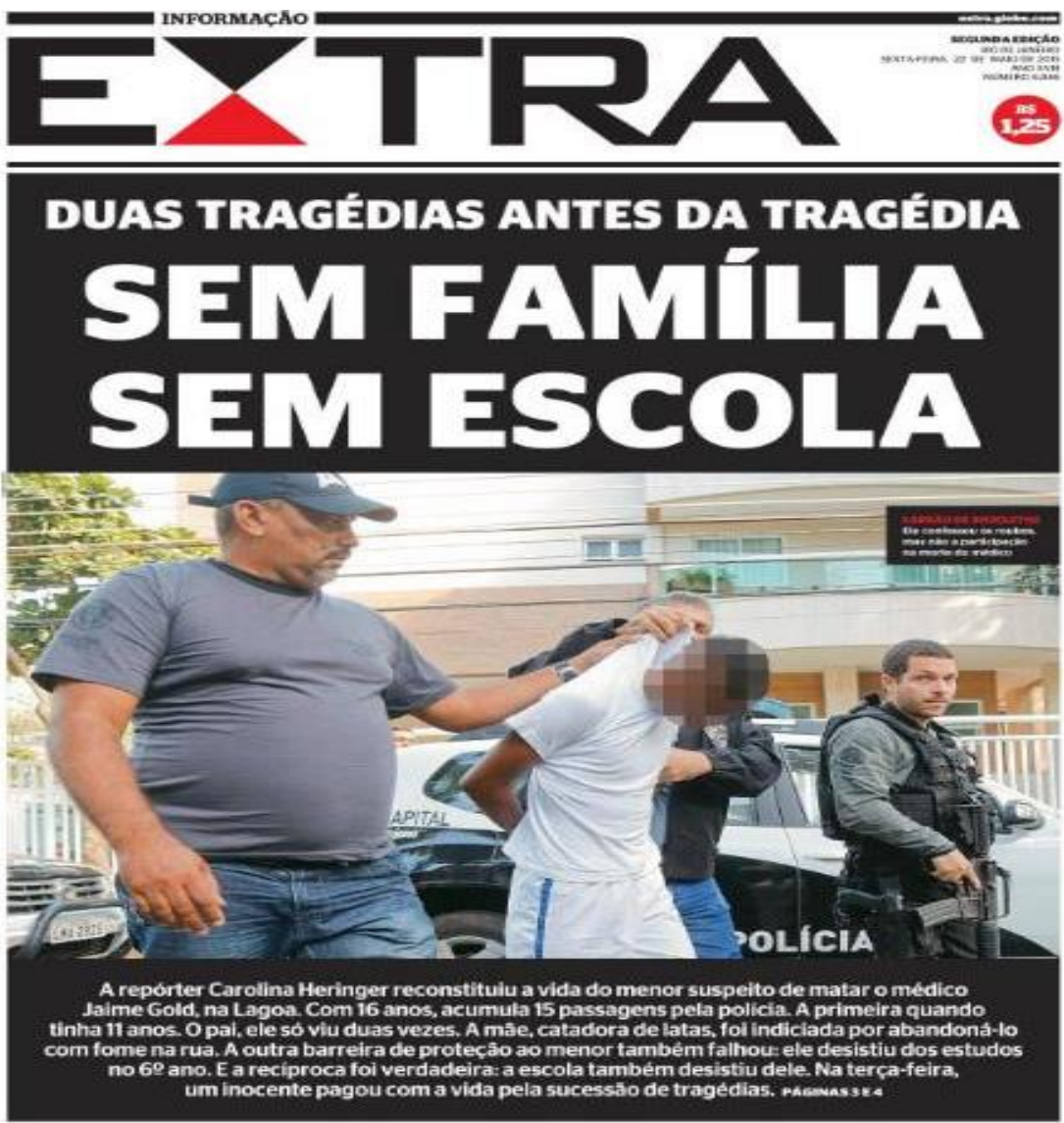

${ }^{17}$ Jornal Extra de 22/05/2015 


\section{Lide do jornal Extra}

A repórter Carolina Heringer reconstituiu a vida do menor suspeito de matar o médico Jaime Gold, na Lagoa. Com 16 anos, acumula 15 passagens pela polícia. A primeira quando tinha 11 anos. O pai, ele só viu duas vezes. A mãe, catadora de latas, foi indiciada por abandoná-lo com fome na rua. A outra barreira de proteção ao menor também falhou: ele desistiu dos estudos no $6^{\circ}$ ano. E a recíproca foi verdadeira: a escola também desistiu dele. Na terça-feira, um inocente pagou com a vida pela sucessão de tragédias. PÁGINAS 3 E 4

Pode-se observar a designação de menor para adolescentes, tanto em documentos legais vigentes, excertos (22) e (23), quanto no Lide do jornal Extra, excerto (24). Essa escolha lexical permite articulações particulares, com vistas a descrever e interpretar significados implícitos e explícitos no texto. A representação linguística do adolescente é construída, nesse Lide, a partir de uma escolha linguístico-discursiva motivada ideologicamente, pois, conforme aponta o trecho, o adolescente em questão é retratado por menor, por ter sido abandonado pelos pais, não frequentar a escola, estar em situação de morador de rua e por sua situação de vulnerabilidade social. Para explicitar o poder da designação, no presente contexto analítico, são evocadas as palavras de Rajagopalan (2003, p. 87), que assinala o seguinte: “é justamente por estar camuflado como um simples ato referencial que tais descrições acabam exercendo tamanha influência sobre o leitor do jornal. À medida que o leitor vai-se acostumando ao rótulo, deixa de perceber que a descrição não passa de uma opinião avaliativa”. Dessa forma, essa opinião avaliativa demostra as posições dos que se favorecem e dos que sofrem as relações sociais que são assimetricamente estruturadas.

Outra forma de representação de crianças e adolescentes em situação de vulnerabilidade social foi a expressão meninos e meninas de rua, pois eram, nas décadas de 1980 e 1990, símbolos de infância e adolescência desamparadas no Brasil. Cabe lembrar que, na segunda metade da década de 1980, começou um movimento de organizações não governamentais de defesa dos direitos das crianças e dos adolescentes. Nesse contexto, consagrou-se a Doutrina da Proteção Integral, que concebeu o tratamento da questão da criança e do adolescente como prioridade absoluta, na Convenção das Nações Unidas sobre os direitos da Criança, em 20 de novembro de 1989. Essa convenção deveu-se à união de esforços de vários países que, durante dez anos, buscaram definir os direitos comuns a todas as crianças e adolescentes para a formulação de normas legais, internacionalmente aplicáveis, capazes de abranger os diferentes cenários socioculturais. 
Já em 1990, foi aprovado, no Congresso Nacional, o Estatuto da Criança e do Adolescente (ECA). Conforme lembra Silva (2015, p. 83), “o Brasil foi o primeiro país da América Latina - e um dos primeiros do mundo - a elaborar uma legislação no que diz respeito à promoção e defesa dos Direitos da Criança e do Adolescente". O ECA é o marco legal que contemplou necessidades de cunho social para mudanças em defesa da ideia de que crianças e adolescentes são também sujeitos de direitos e merecedores do acesso à cidadania e à proteção.

A nova orientação jurídico-constitucional, por conseguinte, concede às crianças e aos adolescentes os direitos fundamentais inerentes à pessoa humana (dentre os quais os direitos à dignidade e ao respeito), além de impor à família, à comunidade, à sociedade em geral e ao Poder Público, o dever de respeitá-los com a mais absoluta prioridade, colocando-os a salvo de qualquer forma de discriminação ou opressão, conforme consta nos artigos $4^{\circ}$, caput e $5^{\circ}$, do Estatuto da Criança e do Adolescente de 1990 e artigo 227, caput, da Constituição Federal de 1988, como se pode observar nos fragmentos (25), (26) e (27).

(25) Art. $4^{o}$ - É dever da família, da comunidade, da sociedade em geral e do Poder Público assegurar, com absoluta prioridade, a efetivação dos direitos referentes à vida, à saúde, à alimentação, à educação, ao esporte, ao lazer, à profissionalização, à cultura, à dignidade, ao respeito, à liberdade e à convivência familiar e comunitária.

(ECA, Livro I, Parte Geral, Título I - Das Disposições Preliminares)

(26) Art. $5^{o}$ - Nenhuma criança ou adolescente será objeto de qualquer forma de negligência, discriminação, exploração, violência, crueldade e opressão, punido na forma da lei qualquer atentado, por ação ou omissão, aos seus direitos fundamentais.

(ECA, Livro I, Parte Geral, Título I - Das Disposições Preliminares)

(27) Art. 227 É dever da família, da sociedade e do Estado assegurar à criança, ao adolescente e ao jovem, com absoluta prioridade, o direito à vida, à saúde, à alimentação, à educação, ao lazer, à profissionalização, à cultura, à dignidade, ao respeito, à liberdade e à convivência familiar e comunitária, além de colocá-los a salvo de toda forma de negligência, discriminação, exploração, violência, crueldade e opressão.

(Constituição Federal, Capítulo VII, Da família, da criança, do adolescente, do jovem e do idoso)

Como se pode observar nos excertos (25), (26) e (27), as crianças e os adolescentes brasileiros são protegidos por leis estabelecidas pelo país. Partindo dessa premissa, o 
arcabouço legal brasileiro traz instrumentos que apontam seus direitos e asseguram sua proteção. Porém, como comenta Moreira (2007, p. 11), apesar de a Constituição brasileira adotar a filosofia da proteção integral às crianças e aos adolescentes, que se define na responsabilização da família, da sociedade e do Estado por sua proteção, o ECA, para a autora, é frequentemente desrespeitado, inclusive por falta de conhecimento da sociedade a seu respeito e, acrescento a esse pensamento, faltam, no País, políticas públicas eficazes.

No Quadro 4.1, intitulado: Representação do termo adolescente na CF, no ECA, no RIUI e no RICM, a seguir, encontram-se excertos da Constituição Federal de 1988, do Estatuto da Criança e do Adolescente de 1990, do Regimento Interno das Unidades de Internação e do Regimento Interno dos Colégios Militares em que o termo "adolescente" está representado por outros termos lexicais de acordo com as práticas sociais estabelecidas nos documentos. Apreciemos.

\section{Quadro 4.1 - Representação do termo adolescente na CF, no ECA, no RIUI e no RICM}

\begin{tabular}{|c|c|c|c|}
\hline $\begin{array}{c}\text { Constituição Federal de } \\
1988\end{array}$ & $\begin{array}{c}\text { Estatuto da Criança e do } \\
\text { Adolescente }\end{array}$ & $\begin{array}{l}\text { Regimento Interno das } \\
\text { Unidades de Internação }\end{array}$ & $\begin{array}{c}\text { (R69) Regimento } \\
\text { Interno dos Colégios } \\
\text { Militares }\end{array}$ \\
\hline $\begin{array}{l}\text { Art. 227. É dever da } \\
\text { família, da sociedade e } \\
\text { do Estado assegurar à } \\
\text { criança, ao adolescente } \\
\text { e ao jovem, com } \\
\text { absoluta prioridade, o } \\
\text { direito à vida, à saúde, à } \\
\text { alimentação, à educação, } \\
\text { ao lazer, à } \\
\text { profissionalização, à } \\
\text { cultura, à dignidade, ao } \\
\text { respeito, à liberdade e à } \\
\text { convivência familiar e } \\
\text { comunitária, além de } \\
\text { colocá-los a salvo de } \\
\text { toda forma de } \\
\text { negligência, } \\
\text { discriminação, } \\
\text { exploração, violência, } \\
\text { crueldade e opressão. } \\
\text { (Redação dada Pela } \\
\text { Emenda Constitucional } \\
\text { no } 65 \text {, de 2010) }\end{array}$ & $\begin{array}{l}\text { Art. 208. Regem-se } \\
\text { pelas disposições } \\
\text { Lei as ações } \\
\text { responsabilidade de } \\
\text { ofensa aos direitos } \\
\text { assegurados à criança e } \\
\text { ao adolescente, } \\
\text { referentes ao não- } \\
\text { oferecimento ou oferta } \\
\text { irregular: } \\
\text { I- do ensino obrigatório; } \\
\text { II- de atendimento } \\
\text { educacional } \\
\text { especializado } \\
\text { portadores } \\
\text { deficiência; } \\
\text { III - de atendimento em }\end{array}$ & 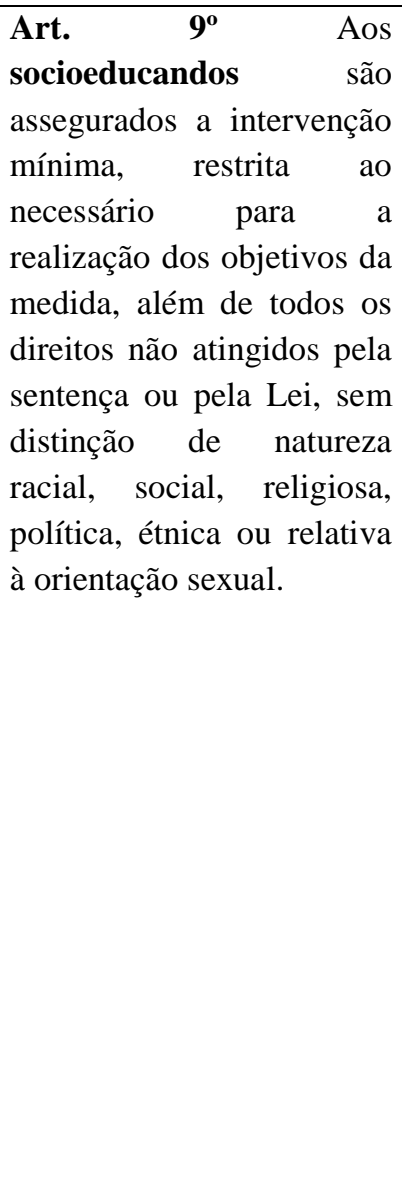 & $\begin{array}{l}\text { Art. 80. Os responsáveis } \\
\text { pelo acompanhamento } \\
\text { escolar e pelas demais } \\
\text { providências relativas à } \\
\text { vida do aluno no CM } \\
\text { serão os pais, os } \\
\text { responsáveis legais ou } \\
\text { uma pessoa idônea, por } \\
\text { delegação, sendo que, em } \\
\text { qualquer caso, esses } \\
\text { responsáveis terão que } \\
\text { residir, obrigatoriamente, } \\
\text { na cidade em que está } \\
\text { situado o CM. }\end{array}$ \\
\hline
\end{tabular}




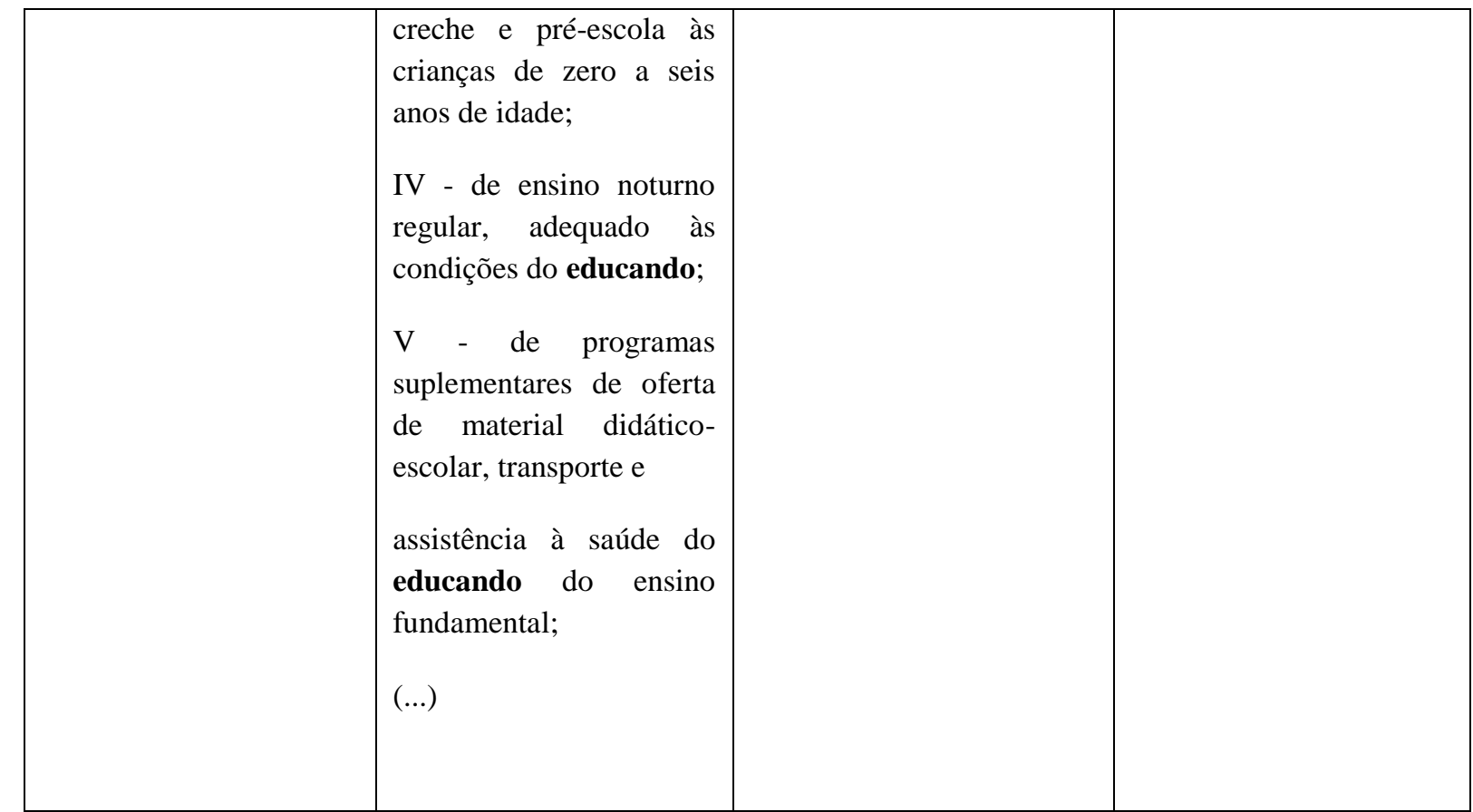

Fonte: elaborado pela autora

Como se pode observar, os excertos destacados, no Quadro 4.1, fazem referência aos adolescentes que estão na faixa etária entre 12 e 18 anos. O termo adolescente, dos documentos selecionados, refere-se a um 'objeto do discurso', expressão cunhada pela linguista Mondada (1994, p. 64). Conforme Mondada (1994),

objeto do discurso caracteriza-se pelo fato de construir progressivamente uma configuração, enriquecendo-se com novos aspectos e propriedades, suprimindo aspectos anteriores ou ignorando outros possíveis, que ele pode associar com outros objetos ao se integrar em novas configurações (...). $\mathrm{O}$ objeto se completa discursivamente. (MONDADA, 1994, p.79).

Resulta que se trata de uma transformação, construção e reconstrução (KOCH, 2003, p. 40) permitidas, conforme o contexto e a progressão textual em que o referente se encontra inserido. A propósito, cabe aqui registrar uma breve discussão sobre referência que, em poucas palavras, concerne a um ato de fala, uma vez que o referente pode ser apontado, em termos de "objeto do discurso", pelo enunciador. No caso, há dois enunciadores institucionalizados, os Colégios Militares e as Unidades de Internação, que equivalem a duas vozes plasmadas em dois documentos escritos, quais sejam, o RICM e o RIUI. O esquema a seguir ilustra esse encadeamento. 
Figura 4.3 - Encadeamento do objeto do discurso nos regimentos

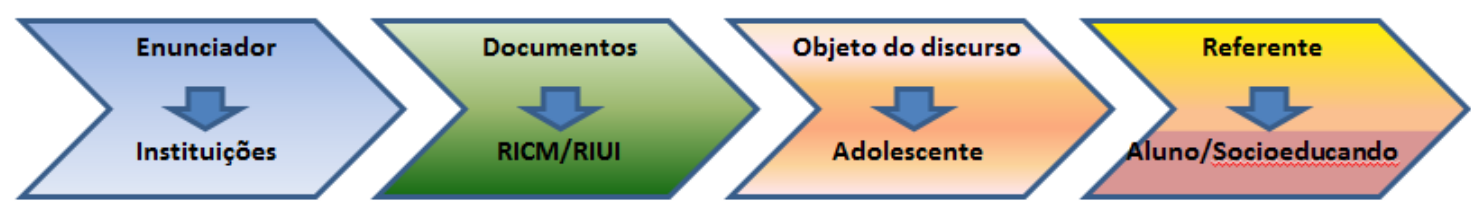

Fonte: elaborado pela autora

O adolescente é o sujeito, no discurso institucional estudado, que, na sua incompletude, está em estado de formação e que necessita ser moldado e educado nos padrões da sociedade, no contexto sociopolítico e cultural em que está inserido. Por isso, ele precisa ser instruído, estimulado e tende a ser corrigido em determinadas situações. Dessa forma, é tratado, nesses documentos, como "objeto de discurso", pois é ele o foco nos documentos abordados. Não obstante, na medida em que o discurso passa de um contexto geral para as particularizações, o "objeto de discurso", quando não é o adolescente, integra-se a novas configurações e, consequentemente, ocorre uma mudança de papéis. O adolescente, então, passa a ser referido como aluno, aquele que precisa de luz em seus conhecimentos; como educando, aquele que precisa ser educado; ou como socioeducando, aquele que precisa ser reintegrado e reeducado socialmente.

Note-se que aluno e socioeducando estão no mesmo campo conceptual, haja vista que ambos necessitam de ser moldados, cada um em seu contexto específico. Em uma visão metafórica, considera-se o adolescente como uma argila que está sendo moldada. O aluno, como referente, é aquele que está em formação, ou seja, tomando forma e fortificando a sua estrutura, apesar de ainda frágil; já o referente socioeducando é aquele que deve ser reconstruído, suas peças devem ser coladas, no sentido de retrabalhar a forma, pois sua estrutura é ainda mais delicada e rúptil, por diversos fatores, como vulnerabilidade social, vulnerabilidade pessoal, educação, família. Em tal caso, a forma que tomou não foi adequada para os padrões sociais e, dessa maneira, tem de ser retrabalhada e remoldada.

Destarte, a representação do termo adolescente aponta para circunstâncias específicas e integra novas situações e configurações com sua mudança de papel, autonomizando-se. Sendo assim, a construção do sentido de adolescente depende de seu contexto e da forma 
como ele é representado no discurso. ${ }^{18}$ Nesse sentido, vale lembrar Fairclough (2001, p. 230) que registrou o seguinte: "a relação das palavras com os significados é de muitos-para-um e não de um-para-um, em ambas as direções: as palavras têm tipicamente vários significados, e estes são ‘lexicalizados' tipicamente de várias maneiras”. Logo, várias palavras podem levar a um só significado, bem como uma palavra pode levar a vários significados.

\subsection{DOCUMENTOS OFICIAIS: NAS TRILHAS DO WORDSMITH TOOLS}

Nesta seção, serão apresentadas as formas que mais aparecem de representação dos adolescentes em quatro documentos oficiais: a Constituição Federativa do Brasil de 1988, a Lei 8.069/90, o Estatuto da Criança e do Adolescente, o Regimento Interno das Unidades de Internação e o Regimento Interno dos Colégios Militares.

Para tanto, será utilizado um conjunto de programas integrados do WordSmith Tools v.6.0 (SCOTT, 2010), destinados à análise linguística, que permite apresentar os aspectos da composição lexical, da temática dos textos selecionados, bem como da sua organização retórica e composicional em termos de gêneros discursivos, como propõe Sardinha (2009).

Nos quatro documentos, foram utilizadas duas ferramentas do WordSmith Tools v.6.0: wordlist (lista de palavras) e concordance (concordâncias). Com a ferramenta wordlist, foi feita uma lista do documento elencando o tamanho do arquivo, a quantidade de palavras diferentes e repetidas e com a respectiva frequência. Assim, depois de formatado o texto em arquivo $t x t$, foi possível acessar a ferramenta wordlist, selecionar o arquivo e fazer a lista de palavras mais frequentes.

\subsubsection{Representação lexical de adolescentes na Constituição Federal de 1988}

Nesta subseção, será mostrado como os adolescentes são representados na Constituição Federal do Brasil de 1988. A ferramenta Wordlist possibilitou que fosse feito um levantamento quanto ao tamanho do arquivo e à quantidade de representações referentes a adolescentes nos documentos. Apreciemos.

\footnotetext{
${ }^{18}$ Segundo Fairclough $(2001,2003)$, o discurso contribui para a construção do que variavelmente é referido como 'identidades sociais' e 'posições de sujeito' para os 'sujeitos' sociais. Por isso, é importante a identificação da área da vida social e o tema representados, além do ângulo ou ponto de vista que ocorre essa representação. Ainda para o autor (2003, p.138 - 139), há formas concretas e abstratas de representar: a mais concreta concerne à representação de eventos sociais específicos; a mais abstrata, a de práticas e estruturas sociais. A representação de um determinado evento social é conectado a outros, implicando, então, uma recontextualização.
} 
Tabela 4.1 - Dimensões e densidade lexical (statistics) da Constituição Federal

\begin{tabular}{ccc}
\hline $\mathbf{N}$ & Overall & $\mathbf{1}$ \\
\hline text file & Overall & Constituição Federal \\
\hline file size & 998.756 & 998.756 \\
\hline tokens (running words) in text & 140.897 & 140.897 \\
\hline tokens used for word list & 131.753 & 131.753 \\
\hline types (distinct words) & 7.705 & 7.705 \\
\hline
\end{tabular}

Fonte: elaborado pela autora com dados da CF 1988

Observa-se, na Tabela 4.1, os títulos dos principais elementos extraídos do texto pela janela de estatística. Na linha text file, encontra-se o nome do arquivo, qual seja, Constituição Federal. A linha file size contém tamanho do arquivo (998.756). A linha tokens (running words) in text apresenta o número total de palavras do texto (140.897). Já na última linha, types (distinct words), há o número de formas distintas (ou vocábulos diferentes) presentes no texto. Nesse universo, pesquisei o termo adolescente e busquei, na Carta Magna, como esses adolescentes estão representados no documento. Ressalte-se que o termo lexical "adolescente" refere-se ao objeto de estudo específico, com faixa etária específica, desdobrando-se em representações encontradas no texto, tais como, aluno, educando, adolescente, estudante. Vejamos o Gráfico 4.1 .

\section{Gráfico 4.1 - Representação lexical de "adolescente" na CF}

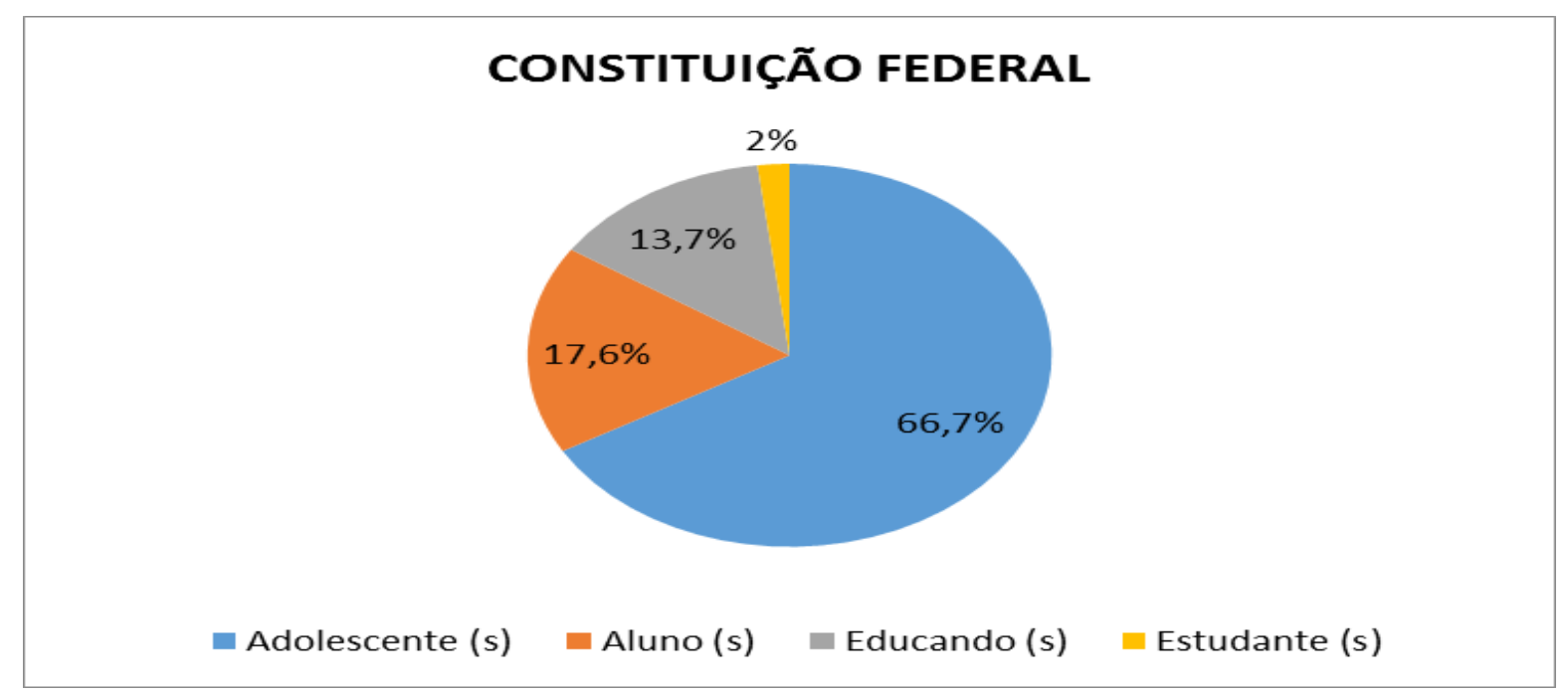

Fonte: elaborado pela autora 
O Gráfico 4.1 registra como é feita a representação lexical de "adolescente" na Constituição Federal de 1988. Observe-se que a promulgação da referida Constituição, no que se refere ao público infanto-juvenil, abriu caminhos para um novo paradigma de atendimento à criança e ao adolescente, que foi materializado com o Estatuto da Criança e do Adolescente de 1990.

Pode-se observar que $66,7 \%$ do universo pesquisado estão representados com o termo adolescente(s). Esses 66,7\% representam 34 ocorrências. Além dessa, há outras três formas de representação, que aparecem em maior incidência, para pessoas com menos de 18 anos na Constituição de 1988: aluno(s), com 17,6\%, com 9 ocorrências; educando(s), com 13,7\%, sendo 7 ocorrências; e estudante(s), com 2\%, com 1 ocorrência. Essa estatística mostra, efetivamente, uma nova visão em termos representacionais do adolescente, pois não mais foram utilizados termos que o esteriotipasse ou o denegrisse, como "menor", por exemplo. Percebe-se, além disso, que, com a inserção dos vocábulos aluno, educando e estudantes, estabelece-se a ideia do direito à educação.

O direito à educação à vida, à saúde, à alimentação, ao lazer, à profissionalização, à cultura, à dignidade, ao respeito, à liberdade, à convivência familiar e comunitária para meninos e meninas são alguns dos direitos relacionados diretamente à Constituição da República de 1988 e ao Estatuto da Criança e do Adolescente (ECA).

\subsubsection{Representação lexical de adolescentes no Estatuto da Criança e do Adolescente}

O Estatuto da Criança e do Adolescente, Lei Federal nº 8.069 (promulgada em julho de 1990), versa sobre os direitos e deveres das crianças e adolescentes em todo o Brasil. É considerado um grande avanço em termos de lei, porque, a partir dele, crianças e adolescentes brasileiros, sem distinção de raça, cor ou classe social, passaram a ser reconhecidos como sujeitos de direitos e deveres, considerados como pessoas em desenvolvimento a quem se deve prioridade absoluta do Estado. Assim, faz-se necessário que seja feita uma análise dos aspectos da composição lexical, como a lista de dimensões e densidade lexical (statistics), dessa lei de tamanha relevância, para fins de análise e ilustração. Apreciemos. 
Tabela 4.2 - Dimensões e densidade lexical (statistics) do ECA

\begin{tabular}{ccc}
\hline N & Overall & 1 \\
\hline text file & Overall & $\begin{array}{c}\text { Estatuto da Criança e do } \\
\text { Adolescente }\end{array}$ \\
\hline file size & 218.724 & 218.724 \\
\hline tokens (running words) in text & 32.309 & 32.309 \\
\hline tokens used for word list & 30.476 & 30.476 \\
\hline types (distinct words) & 3.527 & 3.527 \\
\hline
\end{tabular}

Fonte: elaborado pela autora com dados do ECA

O ECA demarcou um campo especial no ordenamento brasileiro. Nota-se, na Tabela 4.2, quanto ao tamanho, que é um texto menor que a Constituição do Brasil de 1988, como se pode observar na linha file size (218.724), com um total de 32.309 palavras - tokens (running words) in text. Já a linha do tokens used for word list apresenta 30.476 de itens (ou ocorrências) usadas para estruturar o word list do texto.

Por exemplo, a frase "Nenhuma criança ou adolescente será objeto de qualquer forma de negligência, discriminação, exploração, violência, crueldade e opressão, punido na forma da lei qualquer atentado, por ação ou omissão, aos seus direitos fundamentais” possui trinta e dois itens lexicais: Nenhuma(1) criança(2) ou (3) adolescente(4) será(5) objeto(6) de(7) qualquer(8) forma(9) de(10) negligência(11), discriminação(12), exploração(13), violência(14), crueldade(15) e(16) opressão(17), punido(18) na(19) forma(20) da(21) lei(22) qualquer(23) atentado(24), por(25) ação(26) ou(27) omissão(28), $\operatorname{aos}(29) \quad \operatorname{seus(30)}$ direitos(31) fundamentais(32). Por fim, o ECA possui 3.527 vocábulos distintos presentes no texto. Nesse viés estatístico, ilustra-se, a seguir, como estão representados os adolescentes no Estatuto da Criança e do Adolescente. 


\section{Gráfico 4.2 - Representação lexical de "adolescente" no ECA ESTATUTO DA CRIANÇA E DO ADOLESCENTE}

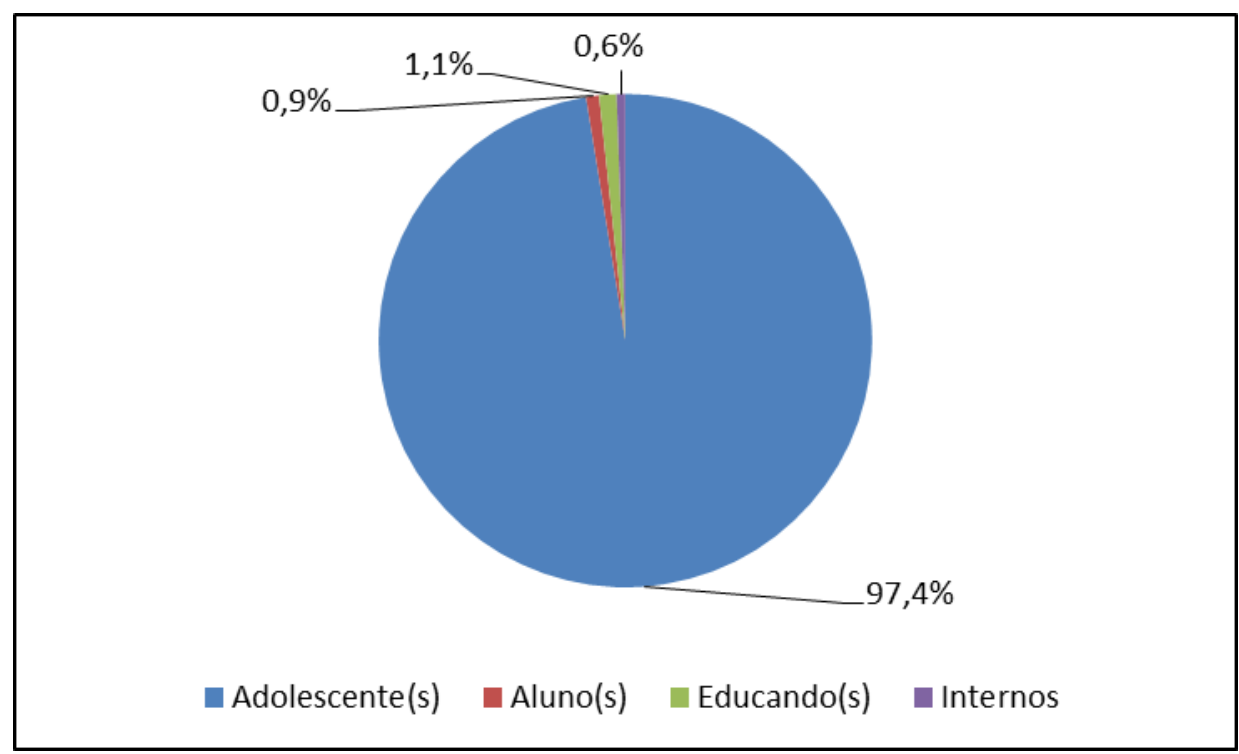

Fonte: elaborado pela autora

No Gráfico 4.2, que representa o ECA, há 97,4\% de ocorrências de adolescente(s), somando-se a 343; 1,1\% de educando(s), com 4 ocorrências; 0,9\% de aluno(s), com 3 ocorrências; e 0,6\% de interno(s), com 2 ocorrências. A grande incidência do termo adolescente pode evidenciar um olhar voltado para os adolescentes de diferentes realidades, com vulnerabilidade social ou não, o que sugere uma grande evolução em termos de paradigmas.

Ressalte-se que o ECA propõe grandes e significativas mudanças em relação ao Código de Menores, legislação anterior instituída em 1979, como, por exemplo, a proteção e a garantia dos direitos das crianças e dos adolescentes e, aos menores de dezoito anos, a inimputabilidade penal ${ }^{19}$. Ademais, pode-se notar um caráter transformador no que se refere ao acesso à justiça, que diz respeito à proteção judicial dos interesses judiciais, difusos e coletivos referentes às crianças e aos adolescentes. É isso que garante, ao menos na forma da lei, mas que nem sempre é efetivado, por falta de políticas públicas eficazes em âmbito nacional, o acesso à educação e a serviços de saúde à população infanto-juvenil e aos adolescentes privados de liberdade, os socioeducandos, representados no ECA como internos.

\footnotetext{
${ }^{19}$ A redação do art. 228 da Constituição da República Federativa do Brasil de 1988 dispõe que os menores de dezoito anos são inimputáveis. Salienta-se que inimputabilidade não é sinônimo de impunidade, pois os adolescentes entre doze e dezoito anos incompletos que praticarem ato infracional poderão ser submetidos às medidas socioeducativas.
} 
Cabe lembrar que o ECA, ao diferenciar criança e adolescente, no art. $2^{\circ}$, "fê-lo para (um dos motivos primordiais) aferir a capacidade de entendimento para aplicação da medida socioeducativa” (ISHIDA, 2013, p. 243). Nesse sentido, faz-se necessário destacar que sobre a medida socioeducativa de internação, o art. 121 do ECA determina que

(28) Art. 121. A internação [Identificado] constitui [processo relacional identificativo do tipo equativo] medida privativa de liberdade, sujeita aos princípios de brevidade, excepcionalidade e respeito à condição peculiar de pessoa em desenvolvimento [Identificador].

(ECA, Livro II, Parte Especial, Título III - Da Prática de Ato Infracional, Seção VII - Da Internação)

No excerto (28), o ECA, na intenção de garantir os direitos do adolescente privado de liberdade, condiciona a internação a três princípios identificadores: a brevidade, estabelecendo que a medida deve perdurar tão somente para necessidade de readaptação do adolescente; a excepcionalidade, no sentido em que deve ser a última medida a ser aplicada pelo Juiz quando houver ineficácia de outras; e o respeito à condição peculiar de pessoa em desenvolvimento, visando manter condições gerais para seu desenvolvimento, como é o caso de garantir educação, escola e profissionalização para o socioeducando. Porém, nem sempre a internação é constituída por esses princípios identificadores, o que acarreta o descumprimento do que é estabelecido no art. 121 do ECA, como ocorre, por exemplo, nas Unidades de Internação.

Cabe ressaltar, conforme lembra Moreira (2013, p. 155), que, crianças e adolescentes, no texto do ECA, estão representados de duas formas distintas: uma, no Livro I - Parte Geral e outra, no Livro II - Parte Especial. Na Parte Geral, a criança e o adolescente são representados como detentores de direitos sociais, já na Parte Especial, eles são representados em função dos crimes que praticam, ou que são praticados contra eles. Cabe destacar, nesse viés, que, como observado no Gráfico 4.2, não há referência ao termo socioeducando, diferentemente do regimento que veremos abaixo.

\subsubsection{Representação lexical de adolescentes no Regimento Interno das Unidades de Internação}

O Regimento das Unidades de Internação tem como objetivo normatizar as quatro Unidades de Internação, quais sejam: Unidade de Atendimento Inicial (UAI), Unidade de Internação de Planaltina (UIP), Unidade de Internação do Recanto das Emas (UNIRE), Unidade de Internação de São Sebastião (UISS) e Unidade de Internação de Santa Maria 
(UISM). Note-se, na Tabela 4.3, que os elementos extraídos do texto pela vertente estatística é bem menor, comparado à Constituição Federal e ao ECA. A seguir, será apresentada, na Tabela 4.3, a lista de dimensões e densidade lexical (statistics) do Regimento Interno das Unidades de Internação.

Tabela 4.3 - Dimensões e densidade lexical (statistics) do RIUI

\begin{tabular}{ccc}
\hline N & Overall & 1 \\
\hline text file & Overall & $\begin{array}{c}\text { Regimento Interno das } \\
\text { Unidades de Internação }\end{array}$ \\
\hline file size & 66.476 & 66.476 \\
\hline tokens (running words) in text & 9.297 & 9.297 \\
\hline tokens used for word list & 8.964 & 8.964 \\
\hline types (distinct words) & 1834 & 1834 \\
\hline
\end{tabular}

Fonte: elaborado pela autora com dados do RIUI

Pode-se observar, na Tabela 4.3, que o tamanho do arquivo, na linha file size é (66.476). A linha tokens (running words) in text apresenta o número total de palavras do texto de (9.297). Já na última linha, types (distinct words), há o número de formas distintas (ou vocábulos diferentes) presentes no texto (1834). Diante dessas estatísticas, vejamos como o adolescente é representado no regimento no Gráfico 4.3.

Gráfico 4.3 - Representação lexical de "adolescente" no RIUI

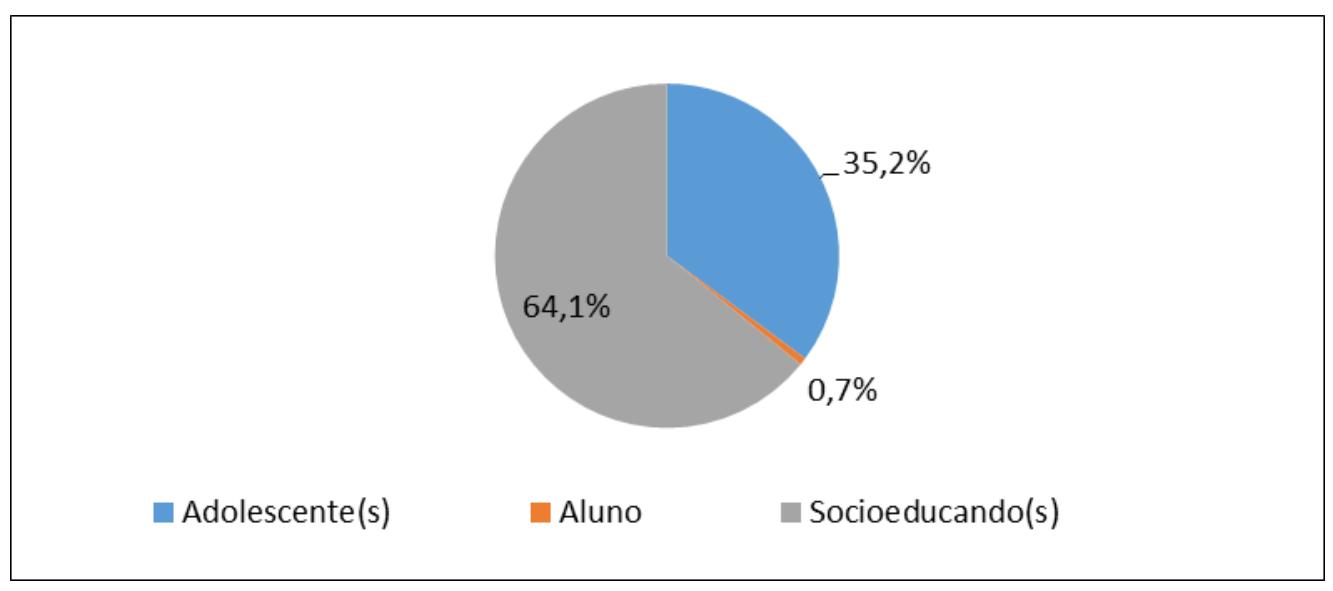

Fonte: elaborado pela autora 
Conforme mostra o Gráfico 4.3, Regimento Interno das Unidades de Internação, "adolescente" está representado em maior incidência pelo termo socioeducando(s), com 64,1\%, 93 ocorrências, seguido de 35,2\% de casos de adolescente(s), com 51 ocorrências e $0,7 \%$ de aluno(s), com 1 ocorrência.

Nesse sentido, pode-se sugerir que o interesse em mitigar a carga depreciativa das palavras voltadas para o campo semântico da adolescência em situação de vulnerabilidade social encontra-se na substituição do item lexical - menor -, que remete ao sentido de valor inferior, passando pelos termos menor delinquente, menor vadio, menor libertino, menor em situação irregular e menor infrator, pelo item lexical socioeducando, resultante de uma derivação parassintética. Trata-se, no caso, da dimensão do social deixando sua marca na interioridade da linguagem, sobretudo se levarmos em conta que ao morfema lexical educforam acrescentados dois afixos: socio- e -ndo. Observe-se que, enquanto o prefixo socioaponta para o sentido do meio social, o elemento sufixal completa o processo de inserção e educação, no caso, daqueles que vivem à margem no tecido heterogêneo da sociedade brasileira.

Então, o adolescente em conflito com a lei que cumpre medidas socioeducativas, de cunho social (adequação) e educacional (pedagógico) em processo de reeducação e reinserção social é denominado socioeducando. ${ }^{20}$

Dando continuidade à forma de representação de adolescentes nos documentos, apresentar-se-á a lista de dimensões e densidade lexical (statistics) do Regimento Interno dos Colégios Militares.

\subsubsection{Representação lexical de adolescentes no Regimento Interno dos Colégios Militares}

A seguir, será apresentada, na Tabela 4.4, o demonstrativo estatístico do Regimento Interno dos Colégios Militares.

\footnotetext{
20 A partir das leituras feitas no decorrer da pesquisa, não foi encontrada uma definição para o termo
} socioeducando. Dessa forma, proponho uma conceituação do termo "socioeducando". 
Tabela 4.4 - Dimensões e densidade lexical (statistics) do RICM

\begin{tabular}{ccc|}
\hline $\mathbf{N}$ & Overall & 1 \\
\hline text file & Overall & $\begin{array}{c}\text { Regimento Interno dos } \\
\text { Colégios Militares }\end{array}$ \\
\hline file size & 109.181 & 109.181 \\
\hline tokens (running words) in text & 17.121 & 17.121 \\
\hline tokens used for word list & 16.520 & 16.520 \\
\hline types (distinct words) & 2.639 & 2.639 \\
\hline
\end{tabular}

Fonte: elaborado pela autora com dados do RICM

Observa-se, na Tabela 4.4, o text file, qual seja, Regimento Interno dos Colégios Militares, com a linha file size contendo o tamanho do arquivo (17.121). A linha tokens (running words) in text apresenta o número total de palavras do texto (16.520). Já na última linha, types (distinct words), há o número de formas distintas (ou vocábulos diferentes) presentes no texto (2.639). Os adolescentes, no Regimento Interno dos Colégios Militares, foram representados de quatro formas. Apreciemos.

\section{Gráfico 4.4 - Representação lexical de "adolescente" no RICM}

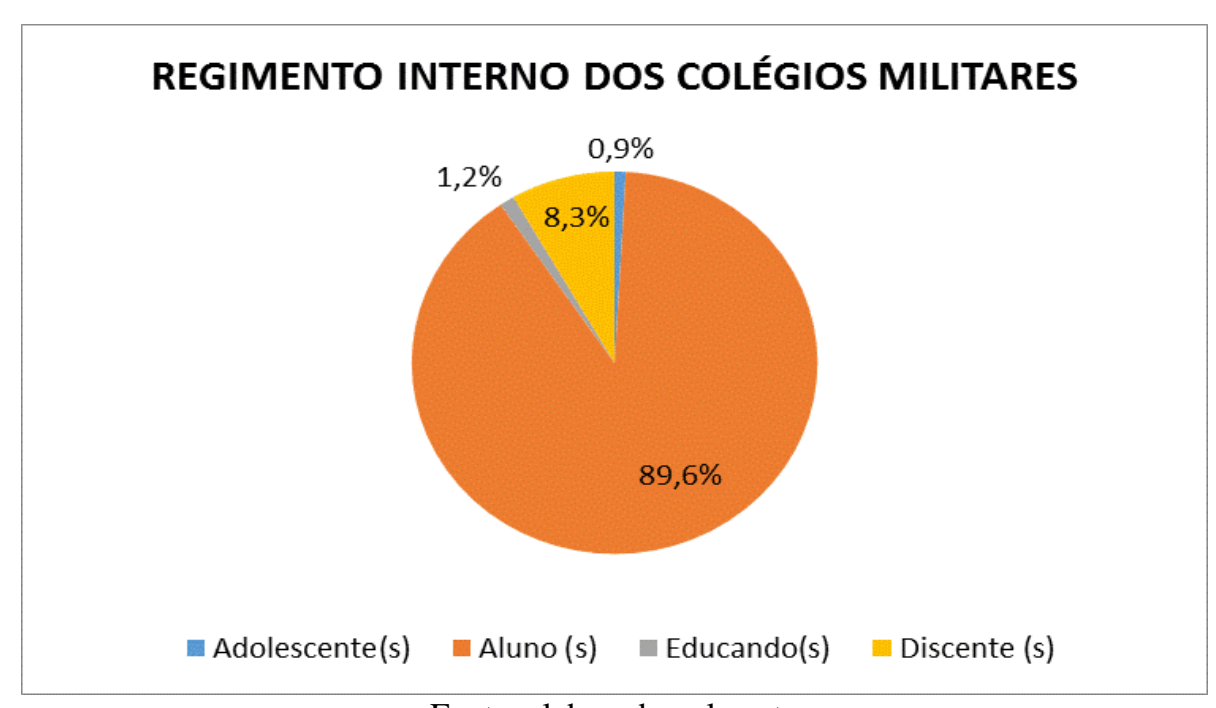

Fonte: elaborado pela autora

No Regimento Interno dos Colégios Militares, representado no Gráfico 4.4, o termo lexical aluno(s) impera aparecendo em 89,6\% dos casos, com 302 ocorrências, enquanto 
discente(s) ocorre em 8,3\%, com 28 ocorrências, seguido de 1,2\% com educando(s), com 4 ocorrências e, por último, 0,9\% de ocorrências do termo adolescente(s), com 3 ocorrências. Nesse diapasão, cabe destacar que, no campo semântico, discente, aluno, educando e estudante são sinônimos, entretanto possuem peculiaridades que os distinguem. Coaduna-se, aqui, com o pensamento de Piazzi (2008), para quem aluno é aquele que pratica a atividade de assistir às aulas, de forma passiva, pois se refere à pessoa que recebe lições do docente, recebe educação e se encontra em um processo de aprendizagem, o que também ocorre com o discente e o educando. $\mathrm{O}$ estudante, por sua vez, possui um caráter ativo, na medida em que é quem pratica a ação de estudar e executar alguma tarefa. Os excertos (29) e (30) ilustram o entendimento de aluno, como passivo e estudante, como ativo. Vejamos.

(29) Art. $4^{\circ}$ Os fundamentos que compõem a sua proposta pedagógica são:

I - oferecer ao aluno condições de acesso ao conhecimento sistemático universal, considerando a realidade de sua vida, proporcionando uma formação integral para o seu desenvolvimento nas áreas cognitiva, afetiva e psicomotora;

II - capacitar o aluno à absorção de conteúdos programáticos qualitativos e de prérequisitos essenciais ao prosseguimento de seus estudos, com base no domínio da leitura, da escrita e das diversas linguagens utilizadas pelo homem, permitindo-lhe analisar, sintetizar e interpretar dados, fatos e cálculos, para resolver situações problemas simples ou complexas, valorizando o seu desenvolvimento pessoal;

III - utilizar procedimentos didáticos e técnicas metodológicas que conduzam o aluno a ocupar o centro do processo ensino-aprendizagem e a construir com a mediação do professor, o próprio conhecimento, fruto de abordagens seletivas, contextuais, interdisciplinares, contínuas e progressivas;

$I V$ - estimular no aluno o desenvolvimento de atitudes crítico-reflexivas, espírito de investigação, criatividade, iniciativa e respeito as diferenças individuais, conduzindo-os a aprender a aprender e aprender a pensar;

$V$ - conduzir o aluno a compreender o significado das áreas de estudo e das disciplinas, enquanto participante do processo histórico da transformação da sociedade e da cultura, desenvolvendo a sua autonomia, valorizando o conhecimento prévio, suas experiências e as relações professor-aluno e aluno-aluno, conscientizando-os de que a aprendizagem adquirida é mais importante que a avaliação educacional de aferição escolar;

VI - desenvolver no aluno atitudes, valores e hábitos saudáveis à vida em sociedade, num ambiente no qual todos possam:

a) compreender e respeitar os direitos e deveres da pessoa humana, do cidadão patriota, da família, dos grupos sociais, do estado e da nação brasileira; b) acessar e dominar recursos científicos relevantes que lhes permitam situar-se criticamente diante da realidade, assumindo responsabilidades sociais; c) preparar-se para participar produtivamente da sociedade, no exercício responsável de sua futura atividade profissional; e d) praticar a atividade física, valorizando e adotando hábitos saudáveis como um dos aspectos básicos da qualidade de vida, agindo com responsabilidade em relação à sua saúde e a saúde coletiva.

(Regimento Interno dos Colégios Militares, Título I Do

Estabelecimento De Ensino, Dos Princípios E Das Finalidades, Capítulo VII Dos Princípios, Das Finalidades e Dos Fundamentos, 2011, p.2) 
No excerto (29), as ações são voltadas para os alunos. Tanto os processos materiais oferecer, capacitar, conduzir e desenvolver quanto o processo mental estimular designam condutas que devem ser executadas em benefício dos alunos. Contudo, o mesmo não ocorre com estudante no excerto abaixo. Vejamos.

(30) Art. 93. A solenidade de início do ano letivo engloba a cerimônia da incorporação dos alunos recém-matriculados no sistema Colégio Militar do Brasil. Sob juramento solene, perante o estandarte do CM, o novo aluno será integrado ao CA:

"incorporando-me ao colégio militar e perante seu nobre estandarte, assumo o compromisso de cumprir com honestidade meus deveres de estudante, de ser bom filho e leal companheiro, de respeitar os superiores, de ser disciplinado e de cultivar as virtudes morais, para tornar-me digno herdeiro de suas gloriosas tradições e honrado cidadão da minha pátria”.

(Regimento Interno dos Colégios Militares, Título IX Do Corpo Discente, Capítulo I Da Constituição, Do Juramento e Da Saudação Escolar, 2011, p. 32)

Aparecem, no fragmento (30), os vocábulos aluno e estudante. Aluno, nesse contexto, continua sendo passivo, pois ele sofre a ação de ser integrado ao Corpo de Alunos. Já o estudante, apesar de estar inserido em uma circunstância de modo nesse excerto, tem o dever de praticar a ação de estudar, ler, aprimorar-se, fazer os deveres de casa, não "colar" na prova.

O estudo de como os adolescentes eram representados e como o são, nos Documentos Oficiais, aponta para o avanço no trato de/com crianças e adolescentes, reconhecidos como sujeitos de direitos e deveres. Antes rotulados de menores abandonados, menores libertinos, menores vadios, menores delinquentes, menores em situação irregular, por estarem em situação de vulnerabilidade social, hoje são representados, na maioria das vezes, por crianças e adolescentes.

Entretanto, apesar de os documentos trazerem uma mudança significativa na forma de se referir ao adolescente, ainda não houve mudança na realidade sociocultural de muitos deles. Isso resulta que a cidadania se torna um elemento distante da realidade. Conforme lembra Carvalho (2011, p. 63), “o conceito de cidadania hoje está também ligado à promoção de ações que garantam igualdade de oportunidades, assegurando a todos educação, saúde e nutrição”. De acordo com Fairclough (2003, p. 161), alcançar identidade social em sentido pleno é uma questão não só de assumir papéis sociais, mas de os personificar, investindo-os com a personalidade própria, representando-os de forma distintiva. Visto por esse ângulo, os problemas referentes às crianças e aos adolescentes vão além da nomenclatura e da 
representação, "uma vez que se interceptam nas esferas da sociedade como um todo, nos âmbitos: econômico, político e social" (SILVA, 2015, p. 82).

A partir das análises lexicais acima, será apresentada, a seguir, uma análise da representação dos adolescentes nos regimentos dos Colégios Militares e das Unidades de Internação.

\subsection{O REGIMENTO COMO GÊNERO TEXTUAL E AÇÃO SOCIAL}

Regimento Interno configura um tipo de documento que apresenta um conjunto de normas estabelecidas para regulamentar a organização e o funcionamento de determinado órgão. Esse conceito vai ao encontro da visão de Bakhtin (2003, p. 283), para quem determinados tipos de enunciados são gerados por uma função específica (científica, técnica, oficial e até mesmo cotidiana), voltada, em geral, para determinadas condições de comunicação, particulares de cada campo. As múltiplas formas de se dirigir ao destinatário e as diversas concepções típicas de destinatários, de leitores, de ouvintes, de modos singulares mais ou menos estruturados, convencionados sócio-historicamente, são fatores que propiciam reconhecer um texto como pertencente a um gênero específico.

Nessa perspectiva, vale lembrar que Fairclough (2003) reconhece os gêneros como aspectos discursivos nas formas de agir e interagir por meio de eventos sociais com níveis de abstração distintos. Pondero, em relação ao gênero Regimento, que, em termos faircloughoueanos, esse gênero está inserido no "gênero situado", uma vez que cumpre funções em situações discursivas específicas. Nessa vertente do gênero Regimento, Marcuschi (2005) lembra que o gênero regimental, além de configurar um tipo relativamente estável de texto, costuma manter uma especificação estrutural.

De acordo com Lima (2015), o RI é estruturado em unidades de articulação, como: títulos, capítulos e seções, que se subdividem em artigos (unidade básica); parágrafos, incisos, alíneas, itens e subitens (unidades complementares). Sugere o referido jurista que cada artigo se restringe a um único assunto, princípio ou regra, de modo que aspectos complementares do sentido oracional e explicações de normas contidas em princípio ou termo estabelecidos no caput do artigo ou do parágrafo são expressos por meio de incisos. Note-se, ainda, que um caput de artigos não é desdobrado em incisos se já tiver sido complementado por parágrafos, assim como as alíneas complementam o sentido oracional apenas de incisos, e os itens complementam apenas de alíneas. 
O Regimento Interno deve ser iniciado do geral para o particular, ou seja, das funções e competências mais gerais do órgão até as áreas menores da escala hierárquica. Primeiramente, detalham-se as competências gerais da instituição. No caso desta tese, trata-se de duas instituições: Colégio Militar de Brasília e Unidade de Internação de Santa Maria.

No gênero do documento em questão, a estrutura do órgão institucional deve ser apresentada logo nos primeiros artigos. Ela é colocada em sequência numérica, por nível hierárquico, seguindo a estrutura definida no decreto de estruturação. O Regimento Interno, conforme Lima (2015), deve possuir redação concisa e objetiva, de forma que a competência de cada unidade administrativa seja bem explicitada. Além disso, devem ser usados verbos (processos, para a LSF) no infinitivo que expressem bem a ação desempenhada. Tais processos verbais devem estar correlacionados ao nível hierárquico: coordenação - coordenar, supervisionar, planejar, dirigir, formular, promover, analisar; diretoria - planejar, dirigir, formular, coordenar, promover, analisar, supervisionar; gerência - gerenciar, analisar, elaborar, avaliar, orientar, controlar, acompanhar; núcleo - executar, efetuar, confeccionar, arquivar, classificar, registrar, emitir e preparar entre outras ações linguístico-discursivas.

Em seguida, será apresentada a estrutura textual/composicional dos dois regimentos analisados neste trabalho. Por um lado, o documento geral dos Colégios Militares. Por outro, os regimentos que regulam as UI. Serão destacados os dois, porque os regimentos dos CM e das UI têm divisão diferenciada, pois o dos Colégios Militares é dividido em títulos que contêm capítulos; já o das Unidades é constituído de capítulos que contêm seções, como se pode observar abaixo.

\section{Quadro 4.2 - Estrutura do Regimento Interno dos Colégios Militares}

\begin{tabular}{|l|l|l|l|}
\hline \multicolumn{1}{|c|}{ Título } & \multicolumn{1}{|c|}{ Capítulo } & \multicolumn{1}{c|}{ Seção } & \multicolumn{1}{c|}{ Artigos } \\
\hline $\begin{array}{l}\text { Título I: Do Estabelecimento de } \\
\text { Ensino, dos Princípios e das } \\
\text { Finalidades }\end{array}$ & I: Do estabelecimento de ensino & & $1^{\circ}$ \\
\hline Título II: Da Organização & $\begin{array}{l}\text { II: Dos princípios, das finalidades e dos } \\
\text { fundamentos }\end{array}$ & & $2^{\circ} / 4^{\circ}$ \\
\hline Título III: Das Atribuições & $\begin{array}{l}\text { II: Da organização geral } \\
\text { II: do comandano porme e diretor de ensino } \\
\text { classe e da COPEMA }\end{array}$ & & $5^{\circ}$ \\
& & & $13 / 12$ \\
\hline
\end{tabular}




\begin{tabular}{|c|c|c|c|}
\hline Título & Capítulo & Seção & Artigos \\
\hline & $\begin{array}{l}\text { III: Do subcomandante } \\
\text { IV: Da subdireção de ensino e da divisão de } \\
\text { ensino } \\
\text { V: Do assistente Administrativo } \\
\text { VI: Da divisão de pessoal } \\
\text { VII: Da divisão aadministrativa } \\
\text { VIII: Do corpo de alunos }\end{array}$ & $\begin{array}{l}\text { I: Das Disposições Gerais } \\
\text { II: Da Secretaria e Da } \\
\text { Ajudância } \\
\text { III: Das Companhias de } \\
\text { Alunos } \\
\text { IV: Da Banda de Música e } \\
\text { do Coral }\end{array}$ & $\begin{array}{l}17 / 24 \\
25 \\
25 \\
26 \\
27 \\
28 \\
29 / 30 \\
31 \\
32 / 33\end{array}$ \\
\hline Título IV: Dos Cursos & ÚNICO: Dos cursos e seus objetivos & & 34 \\
\hline $\begin{array}{l}\text { Título V: Da Inclusão e da } \\
\text { Exclusão }\end{array}$ & $\begin{array}{l}\text { I: do processo seletivo e da matrícula } \\
\text { II: do trancamento e do adiamento da } \\
\text { matrícula } \\
\text { III: da segunda matrícula } \\
\text { IV: da exclusão e do desligamento } \\
\text { V: das transferências }\end{array}$ & & $\begin{array}{l}35 / 41 \\
42 / 44 \\
45 / 46 \\
47 \\
48\end{array}$ \\
\hline $\begin{array}{l}\text { Título VI: Das Contribuições e } \\
\text { Encargos dos Responsáveis }\end{array}$ & $\begin{array}{l}\text { I: Das contribuições e indenizações } \\
\text { II: Dos responsáveis }\end{array}$ & & $\begin{array}{l}49 / 52 \\
53 / 54\end{array}$ \\
\hline Título VII: Do Regime Escolar & $\begin{array}{l}\text { I: Do ano escolar } \\
\text { II: Da frequência } \\
\text { III: Da avaliação da condução do ensino } \\
\text { IV: Da avaliação do rendimento da } \\
\text { aprendizagem } \\
\text { V: Da habilitação ao ano seguinte } \\
\text { VI: Da classificação }\end{array}$ & $\begin{array}{l}\text { Seção I: Das Disposições } \\
\text { Gerais }\end{array}$ & $\begin{array}{l}55 / 59 \\
60 / 62 \\
63 \\
64 / 71 \\
72 / 77\end{array}$ \\
\hline
\end{tabular}




\begin{tabular}{|c|c|c|c|}
\hline Título & Capítulo & Seção & Artigos \\
\hline & & $\begin{array}{l}\text { Seção II: Da recuperação } \\
\text { Seção III: Do apoio } \\
\text { Pedagógico }\end{array}$ & 78 \\
\hline Título VIII: Do Corpo Docente & $\begin{array}{l}\text { I: da constituição } \\
\text { II: da seleção } \\
\text { III: do expediente e da carga horária } \\
\text { IV: da coordenação e da assessoria } \\
\text { V: da frequência e da reposição de aulas }\end{array}$ & & $\begin{array}{l}79 \\
80 / 85 \\
86 / 88 \\
89 / 90 \\
91\end{array}$ \\
\hline Título IX: Do Corpo Discente & $\begin{array}{l}\text { I: da constituição, do juramento e da } \\
\text { saudação escolar } \\
\text { II: da hierarquia, das promoções e do } \\
\text { grupamento escolar } \\
\text { III: dos deveres e direitos dos alunos } \\
\text { IV: do regime disciplinar } \\
\text { V: das agremiações internas } \\
\text { VI: do histórico escolar e dos diplomas } \\
\text { VII: da denominação de turma e das } \\
\text { cerimônias de encerramento de curso e de } \\
\text { ano letivo } \\
\text { VIII: do curso de formação de reservista }\end{array}$ & & $\begin{array}{l}92 / 94 \\
95 / 102 \\
103 / 105 \\
106 / 107 \\
108 / 112 \\
113 / 115 \\
116 / 117 \\
118 / 129\end{array}$ \\
\hline $\begin{array}{l}\text { Título X: Das Disposições } \\
\text { Transitórias e das Prescrições } \\
\text { Diversas }\end{array}$ & $\begin{array}{l}\text { I: das disposições transitórias } \\
\text { II: das prescrições diversas }\end{array}$ & & $\begin{array}{l}130 \\
131 / 138\end{array}$ \\
\hline
\end{tabular}

Fonte: elaborado pela autora com dados do RICM

O Quadro 4.2 apresenta a estrutura composicional detalhada do Regimento Interno dos Colégios Militares (R69). Esse Regimento é dividido em 10 títulos e 138 artigos e tem por finalidade estabelecer preceitos comuns aplicáveis aos Colégios Militares (CM), que tratam do Estabelecimento de Ensino, dos princípios e das finalidades da Instituição Colégio Militar, da organização, das atribuições de todos que fazem parte do Sistema Colégio Militar, como o do Comandante e Diretor de Ensino, do conselho de classe e da COPEMA, o subcomandante, da divisão de pessoal, da divisão administrativa, do corpo de alunos, além de tratarem dos 
cursos, da inclusão e da exclusão, das contribuições e encargos dos responsáveis, regime escolar, do corpo docente, do corpo discente, das disposições transitórias e das prescrições diversas. Cabe ressaltar que as normas perpassam por todas as esferas, desde o Comando, corpo docente até o corpo discente.

Observa-se que esse regimento abrange os treze Colégios Militares do Brasil (Belo Horizonte, Brasília, Campo Grande, Curitiba, Fortaleza, Juiz de Fora, Manaus, Porto Alegre, Recife, Rio de Janeiro, Salvador, Belém e Santa Maria/RS). O ensino nesses treze Colégios Militares é realizado em consonância com a legislação federal de educação e obedece às leis e aos regulamentos em vigor no Exército, em especial às normas e diretrizes do Departamento de Ensino e Pesquisa (DEP), órgão gestor da linha de ensino do Exército. Além desse regimento, os CM possuem o Guia do Aluno, o Guia do Professor e seu próprio regimento, de acordo com as particularidades de cada Colégio Militar, documentos que complementam o R69.

Como já mencionado, o Regimento das Unidades de Internação diferencia-se da estrutura do Regimento dos Colégios Militares, o que pode ser apreciado a seguir.

\section{Quadro 4.3 - Estrutura do Regimento Interno das Unidades de Internação}

\begin{tabular}{|c|c|c|}
\hline CAPÍTULO & SEÇÃO & ARTIGO \\
\hline I: Das disposições gerais & $\begin{array}{l}\text { Seção I: do objetivo e princípios do atendimento socioeducativo } \\
\text { Seção II: da medida socioeducativa de internação } \\
\text { Seção III: das unidades de internação em estabelecimento educacional } \\
\text { Seção IV: dos servidores } \\
\text { Seção V: da equipe de referência }\end{array}$ & $\begin{array}{l}1^{\circ} / 3^{\circ} \\
4^{\circ} \\
5^{\circ} \\
6^{\circ} / 7^{\circ} \\
8^{\circ}\end{array}$ \\
\hline II: Dos direitos, deveres e estímulos & $\begin{array}{l}\text { Seção I: Dos Direitos, Deveres e Estímulos aos socioeducandos. } \\
\text { Seção II: Dos Direitos, Deveres e Estímulos aos Servidores }\end{array}$ & $\begin{array}{l}9 \% / 15 \\
16 / 17\end{array}$ \\
\hline $\begin{array}{l}\text { III: Da recepção, do acolhimento, do } \\
\text { plano individual de atendimento }\end{array}$ & $\begin{array}{l}\text { Seção I: Das Disposições Gerais } \\
\text { Seção II: Da Recepção e do Acolhimento } \\
\text { Seção III: Do Estudo de Caso e do Plano Individual de Atendimento }\end{array}$ & $\begin{array}{l}18 \\
19 / 20 \\
21 / 22\end{array}$ \\
\hline IV: Das transferências e remoções & & 23 \\
\hline V: Das políticas sociais & $\begin{array}{l}\text { Seção I: Das Disposições Gerais } \\
\text { Seção II: Da Assistência Material } \\
\text { Seção III: Da Assistência à Escolarização } \\
\text { Seção IV: Da Assistência à Saúde } \\
\text { Seção V: Da Assistência Social } \\
\text { Seção VI: Da Assistência Cultural, Esportiva e ao Lazer } \\
\text { Seção VII: Da Assistência ao Trabalho e Empregabilidade } \\
\text { Seção VIII: Da Assistência Religiosa } \\
\text { Seção IX: Da Assistência Jurídica }\end{array}$ & $\begin{array}{l}24 / 25 \\
26 \\
27 / 30 \\
31 / 37 \\
42 / 45 \\
46 / 50 \\
51 / 52 \\
53 / 57\end{array}$ \\
\hline VI : Da segurança & $\begin{array}{l}\text { Seção I: Disposições gerais } \\
\text { Seção II: Ações preventivas } \\
\text { Seção III: Acesso às Unidades } \\
\text { Seção IV: Acesso de grupos religiosos } \\
\text { Seção V: Acesso ao Defensor Público e ao Advogado particular } \\
\text { Seção VI: Entrada de visitantes } \\
\text { Seção VII: Contato telefônico ou via vídeo conferência }\end{array}$ & $\begin{array}{l}58 / 59 \\
60 \\
61 / 63 \\
64 / 67 \\
68 / 69 \\
70 / 76 \\
77\end{array}$ \\
\hline
\end{tabular}




\begin{tabular}{|l|l|l|}
\hline \multicolumn{1}{|c|}{ CAPÍTULO } & \multicolumn{1}{|c|}{ SEÇÃO } & \multicolumn{1}{|c|}{ ARTIGO } \\
\hline VII: Do regulamento disciplinar & Seção I: Das disposições gerais & $78 / 84$ \\
& Seção II: Das transgressões & $85 / 88$ \\
& Seção III: Das medidas aplicáveis & $89 / 92$ \\
& Seção IV: Das circunstâncias atenuantes & 93 \\
& Seção V: Das circunstâncias agravantes & 94 \\
\hline $\begin{array}{l}\text { VIII: da revisão e divulgação deste } \\
\text { regimento }\end{array}$ & Seção I: das disposições finais e transitórias & $95 / 100$ \\
\hline
\end{tabular}

Fonte: elaborado pela autora com dados do RIUI

O Quadro 4.3 apresenta a estrutura composicional do Regimento das Unidades de Internação. Esse Regimento é composto por oito capítulos e 100 artigos e regula os parâmetros de funcionamento e competências das Unidades de execução da medida socioeducativa de Internação do Distrito Federal, considerando os preceitos da Lei 8.069/90 Estatuto da Criança e do Adolescente e demais normativas referentes à infância e à juventude no Brasil. Os capítulos integram disposições gerais, direitos, deveres e estímulos aos socioeducandos e aos servidores, recepção, acolhimento, Plano Individual de Atendimento, transferências e remoções, Políticas Sociais de Assistência, segurança, Regulamento Disciplinar, revisão e divulgação do Regimento. Esse Regimento tem uma estrutura diversificada do Regimento dos Colégios Militares, pois não aborda temas como atribuições de cada servidor das Unidades, o que pode ser observado como um vácuo no documento.

O que mais cabe ressaltar é que não dá destaque ou ênfase a questões educacionais, tampouco profissionalizantes dentro das Unidades de Internação, o que acarreta, sem dúvida, a quebra do objetivo de reinserção do adolescente na sociedade. Além disso, não aborda temas importantes como a Lei antidroga. Ademais, não faz referência aos servidores e suas respectivas funções. Talvez seja por isso que fui à Secretaria diversas vezes para ver se o documento já havia sido atualizado e tenha sempre recebido uma resposta negativa, porque em todas as ocasiões que lá estive, durante quatro anos, sempre havia um responsável diferente para elaborar e confeccionar o novo Regimento das Unidades.

\subsubsection{As cadeias de gêneros discursivos normativos em ação}

Os gêneros discursivos são reconhecidos por Chouliaraki e Fairclough (1999, p. 144) como "um mecanismo articulatório que controla o que pode ser usado e em que ordem, incluindo configuração e ordenação de discursos". No caso de normas e leis, destaca-se que, no Brasil, já existe, desde 1991, o Manual de Redação da Presidência da República, revisado e reeditado em 2002, que tem por objetivo apresentar as normas de redação de atos e comunicações oficiais. Outrossim, foi criada a Lei Complementar $\mathrm{n}^{\circ} 95$ que dispõe acerca da 
elaboração, da redação, da alteração e da consolidação das leis, como é determinado pelo parágrafo único do art. 59 da Constituição Federal de 1988 e que, além disso, estabelece normas para a consolidação dos atos normativos.

Ressalte-se que os gêneros discursivos são representados de maneiras diferenciadas, o que propicia a identificação de relações entre discursos diferentes. Como bem observa Moreira (2013, p. 116), “as sociedades modernas complexas envolvem a formação em rede de diversas práticas sociais por meio de variados domínios ou campos da vida social, tais como a economia, a educação, assim como a vida familiar, que perpassam diferentes escalas da vida social (global, regional, nacional e local)". Isso significa que os textos aqui analisados se situam em uma cadeia de gêneros discursivos normativos que estabelecem relações de poder em suas práticas sociais e têm força de lei dentro de determinada instituição.

Cadeias de gêneros têm significação específica: são diferentes gêneros que se ligam com regularidade, envolvendo transformações sistemáticas de gênero em gênero. Cadeias de gêneros contribuem para a possibilidade de ações que transcendem diferenças no espaço e no tempo, unindo eventos sociais a práticas sociais diferentes, países diferentes, tempos diferentes, facilitando a capacidade reforçada para 'ação à distância' que tem sido considerada um traço definidor da 'globalização' contemporânea, e, dessa maneira, tem facilitado o exercício do poder. (FAIRCLOUGH, 2003, p. 31)

O Regimento Interno dos Colégios Militares integra uma cadeia de gêneros. O Sistema Colégio Militar do Brasil subordina-se ao seguinte conjunto de leis, ordenadas hierarquicamente da mais abrangente para a mais específica: 
Figura 4.4 - Cadeia de Gêneros Discursivos do Regimento Interno dos Colégios Militares

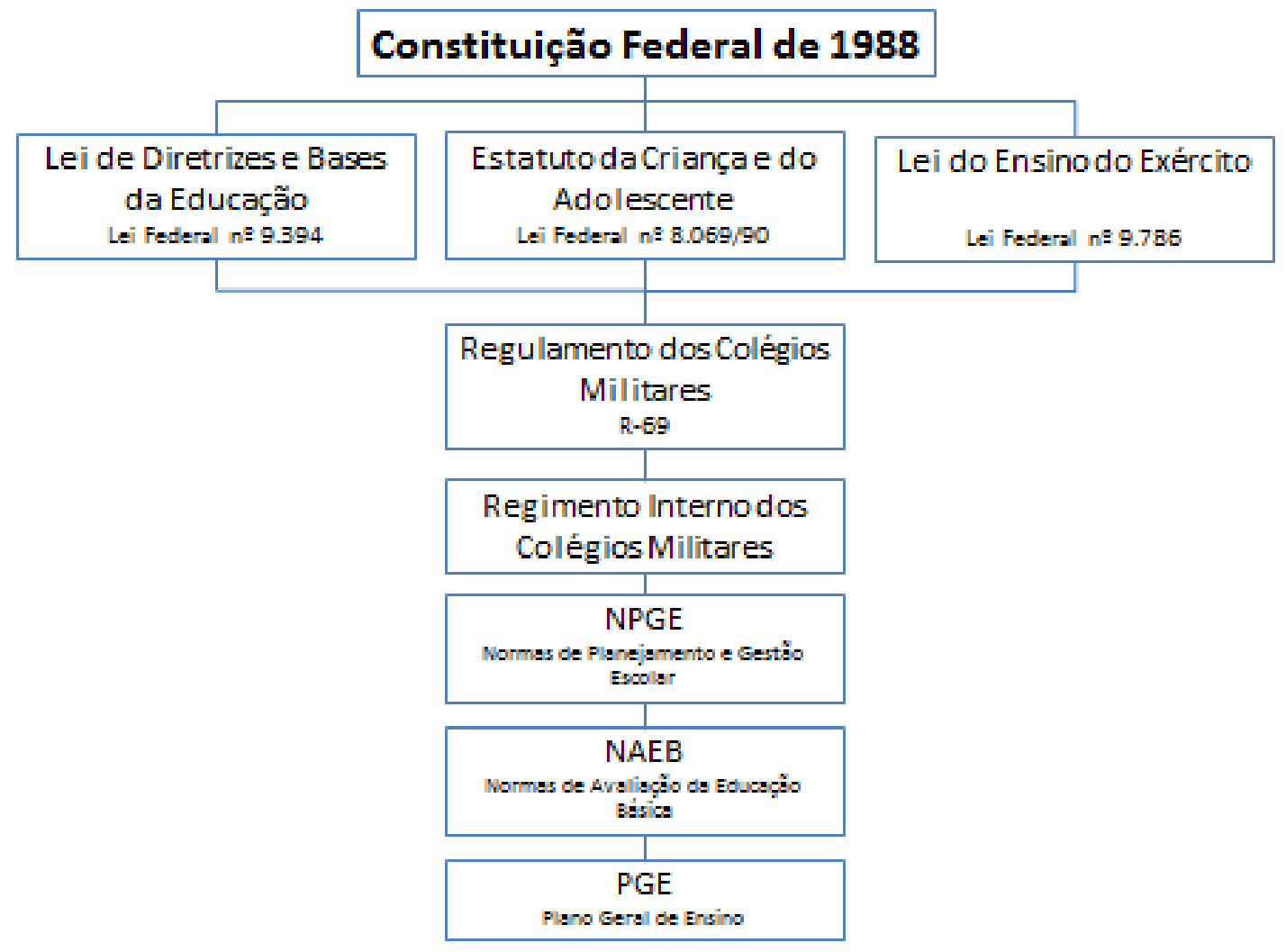

Fonte: elaborado pela autora

A Figura 4.4 ilustra a cadeia de gêneros documentais hierarquicamente relatados e aponta para os gêneros de governança ${ }^{21}$. Um gênero, dentro de cada cadeia, insere-se de acordo com suas próprias características, em relações tanto de retrospectiva como de prospectiva com os gêneros que o precedem e o seguem. Portanto, os documentos normativos dialogam entre si, como forma de sustentar as relações de poder que se estabelecem no Sistema Colégio Militar.

Os gêneros de governança, segundo Chouliaraki e Fairclough (1999), são caracterizados por propriedades específicas de recontextualização - a apropriação de elementos de uma prática social dentro de outra, colocando a primeira no contexto da última, pois está relacionada a questões do contexto de cultura em que cada gênero é configurado. Cabe lembrar que "recontextualização", é um conceito desenvolvido na sociologia da educação e que pode ser aplicado na análise textual. Nesse sentido, salienta-se que o princípio

${ }^{21}$ Para Fairclough (2003), determinados gêneros que atuam em escala local são associados a uma rede de práticas sociais delimitadas; outros são especializados e atuam em escala global pela (inter)ação, por meio de redes de comunicação (gêneros de governança). O termo 'governança'é aqui empregado em vários e amplos sentidos, isto é, para qualquer atividade dentro de uma instituição ou organização direcionada para regular ou gerenciar uma outra (rede de) prática(s) social(ais). 
recontextualizador propicia a construção da ordem e ordenamentos de seu próprio discurso, conforme o pensamento de Bernstein $(1996)^{22}$. Dessa forma, os gêneros de governança possibilitam ligar diferentes escalas - conecta-se o local e o particular ao nacional/regional/global e geral. Os gêneros, portanto, são importantes para fortalecer não só as relações estruturais entre, por exemplo, o mundo acadêmico e o mundo dos negócios, mas também ordenar relações entre o local, o nacional, o regional e o global (MOREIRA, 2013, p. 118). Nesse sentido, mudanças de gênero são pertinentes para reestruturação e reescalonamento da vida social no novo capitalismo, o que pode também ser observado na construção das leis que regulamentam o direito de crianças e de adolescentes. Portanto, o Regimento Interno dos Colégios Militares é um gênero nacional para o sistema Colégio Militar. Já a Constituição Federal de 1988, a Lei do Ensino do Exército (Lei Federal n ${ }^{\circ}$ 9.786), a Lei de Diretrizes e Bases da Educação (Lei Federal n ${ }^{\circ}$ 9.394) e o Estatuto da Criança e do Adolescente (Lei Federal n ${ }^{\circ}$ 8069/90) estão voltados para a governança nacional. Sugerese, entretanto, que o Plano Geral de Ensino, documento de periodicidade anual elaborado por cada Colégio Militar, subordinado ao RICM, pode ser considerado um subgênero voltado para governança regional.

Observe-se que os textos acima se situam na cadeia de gêneros discursivos da ordem jurídica (as leis) e da ordem normativa (regimentos e normas). Nessa perspectiva, será apresentada, a seguir, uma síntese descritiva de cada documento enfocado em termos de gêneros discursivos.

1) A Constituição Federativa do Brasil de 5 de outubro de 1988 (legislação máxima brasileira) é o conjunto de normas que regulam o Estado Brasileiro que garante direitos e determina deveres para os cidadãos.

2) A LDB, Lei de Diretrizes e Bases da Educação (Lei Federal n 9.394, de 20 de dezembro de 1996), é uma Lei Federal que disciplina, de forma abrangente, a educação escolar em todas as instituições nacionais.

3) A Lei do Ensino do Exército (Lei Federal n 9.786 de 8 de fevereiro de 1999 - DOU $\mathrm{n}^{\circ} 27$ de 9-2-1999) define e estabelece as condições para o funcionamento do Sistema de Ensino do Exército, do qual fazem parte os Colégios Militares.

\footnotetext{
${ }^{22}$ Conforme o pensamento de Bernstein (1996, p. 259), o princípio recontextualizador "seletivamente, apropria, reloca, refocaliza e relaciona outros discursos, para constituir sua própria ordem e seus próprios ordenamentos". Dessa forma, por meio da recontextualização, o discurso desloca-se do seu contexto inicial de produção, sendo modificado e relacionado com outros discursos e, em momento seguinte, é relocado.
} 
4) O ECA, Estatuto da Criança e do Adolescente (Lei Federal n`8.069 de 13 de julho de 1990), é a Lei que cria exigibilidade para os direitos da criança e do adolescente.

5) O R-69, Regulamento dos Colégios Militares (Portaria do Comandante do Exército ${ }^{\circ}$ 42 de 06 de fevereiro de 2008), define os preceitos comuns aos Colégios Militares, tais como organização geral, estrutura organizacional, atribuições e competências dos diversos agentes, condições de matrícula e ingresso de dependentes de civis, dentre outros.

6) O Regimento Interno dos Colégios Militares é um documento expedido pela DEPA (Diretoria de Educação Preparatória e Assistencial) - órgão setorial do Exército encarregado do controle do Sistema Colégio Militar do Brasil - que regula detalhadamente os fundamentos e princípios de funcionamento do Sistema Colégio Militar do Brasil. Detalha a organização, composição das comissões educacionais, constituição do batalhão escolar, das promoções e das premiações, funcionamento da Legião de Honra, regras de disciplina, classificação de comportamento, medidas educativas e relação das transgressões disciplinares, dentre outros.

7) As Normas de Planejamento e Gestão Escolar (NPGE) fazem parte de um documento de periodicidade anual, expedido pela Diretoria de Educação Preparatória e Assistencial, que visa regular o planejamento, a gestão escolar e a execução do ensino no SCMB. Abrange todas as áreas ligadas à gestão do ensino com ênfase para a especificação da documentação de controle, planejamento do ano escolar e a condução didática baseada no ensino por competências. Contêm, ainda, as grades curriculares dos dois ciclos escolares e o Planejamento Geral de atividades escolares que devem ser seguidas por todos os Colégios. As NPGE servem de base para a elaboração dos PGE, documento interno, elaborado por cada um dos 13 Colégios Militares.

8) As Normas de Avaliação da Educação Básica (NAEB) estão em um documento expedido e revisado pela DEPA, anualmente, que contém os princípios e as normas ligadas exclusivamente aos processos avaliativos nos CM. Nesse documento, há o detalhamento sobre o cálculo de notas e médias, periodicidade e peso ponderado das provas, tipos de avaliação e suas normas de confecção e critérios de aprovação. É o documento mais importante sobre avaliação dos Colégios Militares.

9) O PGE, Plano Geral de Ensino, é um documento de periodicidade anual, elaborado por cada CM que reproduz as prescrições gerais previstas nas NPGE e NAEB, as quais devem ser seguidas por todos os integrantes do SCMB e complementadas pelo regionalismo, isto é, pelas peculiaridades que afetam a condução do ensino em cada Colégio (feriados locais, datas 
festivas municipais, feiras de ciências). Contém o planejamento de todas as atividades previstas para o ano letivo a que se refere o PGE.

Essa cadeia de gêneros ocorre, também, nos documentos das Unidades, com o Regimento Interno das Unidades e com o Regimento Interno de Santa Maria, como se pode observar abaixo.

Figura 4.5 - Cadeia de Gêneros Discursivos do Regimento Interno das Unidades de Internação

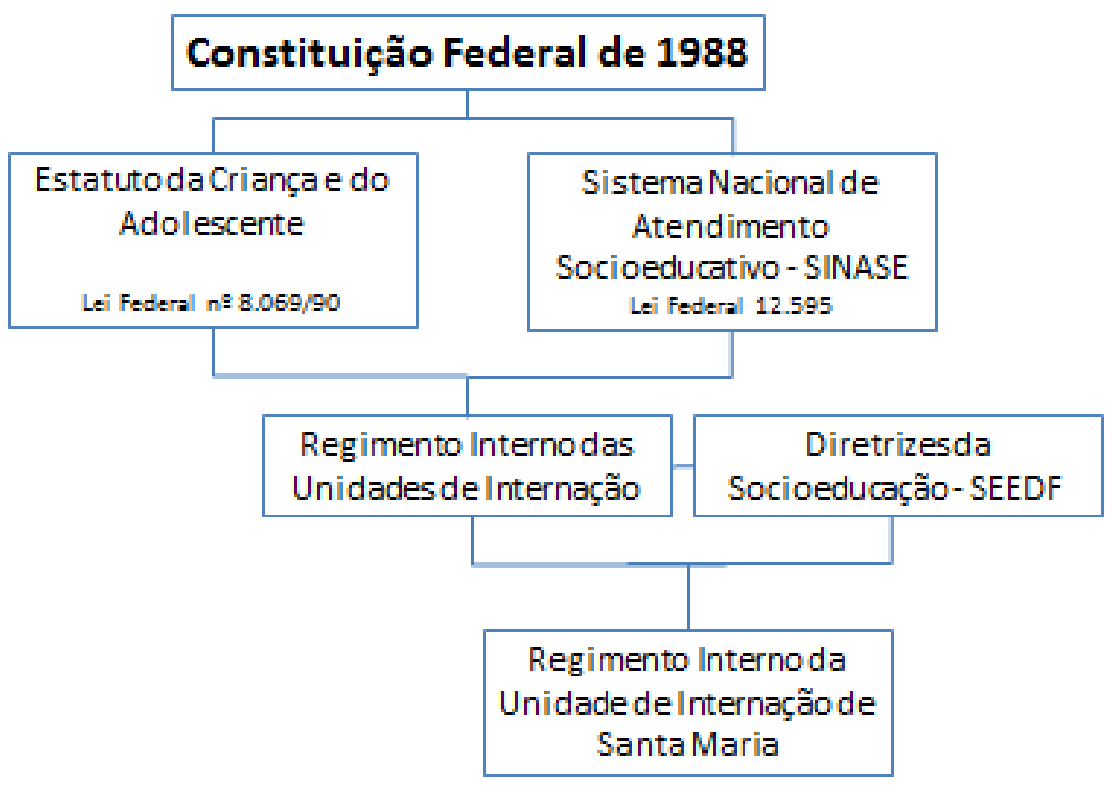

Fonte: elaborado pela autora

Assim como a Figura 4.4, Cadeia de Gêneros Discursivos do Regimento Interno dos Colégios Militares, a Figura 4.5 aponta para os gêneros de governança. Note-se que o Regimento Interno das Unidades de Internação, considerado, aqui, um subgênero regional, é subordinado à Constituição Federal de 1988, ao Estatuto da Criança e do Adolescente (Lei Federal $n^{\circ}$ 8069), e ao Sistema Nacional de Atendimento Socioeducativo - SINASE (Lei Federal $\left.n^{\circ} 12.595\right)$, sendo essa tríade genérica voltada para a governança nacional. Já o Regimento Interno da Unidade de Santa Maria pode ser considerado subgênero textual específico voltado para governança regional, subordinado, sobretudo, ao Regimento Interno das Unidades de Internação. 
Apresentar-se-á, abaixo, uma síntese descritiva de cada documento enfocado em termos de gêneros discursivos.

1) A Constituição Federativa do Brasil de 5 de outubro de 1988 (legislação máxima brasileira) é o conjunto é o conjunto de normas que regulam o Estado Brasileiro que garante direitos e determina deveres para os cidadãos.

2) O ECA, Estatuto da Criança e do Adolescente (Lei Federal n ${ }^{\circ} 8.069$ de 13 de julho de 1990), é a Lei que cria exigibilidade para os direitos da criança e do adolescente

3) O SINASE, Sistema Nacional de Atendimento Socioeducativo (Lei Federal $n^{\circ} 12.595$ de 2012), é a Lei que implica a qualificação e normatização do atendimento socioeducativo em âmbito nacional.

4) O Regimento Interno das Unidades de Internação do Distrito Federal regula os parâmetros de funcionamento e competências das Unidades de execução da medida socioeducativa de Internação do Distrito Federal, considerando os preceitos da Lei 8.069/90 Estatuto da Criança e do Socioeducando e demais normativas referentes à infância e juventude no Brasil.

5) As Diretrizes da Socioeducação orientam a organização do trabalho pedagógico nas Unidades de Internação Socioeducativas e de Internação Cautelar e nas escolas que recebem adolescentes que cumprem medidas socioeducativas de semiliberdade, de liberdade assistida e de prestação de serviço à comunidade, sempre na perspectiva da educação integral, que considera o sujeito em formação como ser multidimensional.

6) O Regimento Interno da Unidade de Santa Maria regula os parâmetros de funcionamento e competência da Unidade de Internação de Santa Maria no Distrito Federal.

Para cada unidade socioeducativa é obrigatória a elaboração de um regimento interno que regule seu funcionamento, por meio da descrição das atribuições e responsabilidades dos profissionais inseridos no quadro de trabalho das Unidades, desde o dirigente até os educadores, e das condições do exercício da disciplina e da concessão de benefícios ordinários e extraordinários, segundo Lei $\mathrm{n}^{\circ}$ 12.594, BRASIL (2012). Ressalte-se, também, que o regimento deveria prever, ainda, a elaboração de um regime disciplinar para controlar o comportamento dos adolescentes acolhidos, por meio do estabelecimento de punições para determinadas atitudes inadequadas dentro do contexto socioeducativo.

Entretanto, não é o que vem ocorrendo quanto à elaboração dos regimentos do sistema socioeducativo, a começar pelo regimento geral das Unidades de Internação, pois parece não existir a preocupação há, pelo menos quatro anos, de confeccionar, de forma específica e cuidadosa, o Regimento das Unidades de Internação, de uma maneira geral. Afirmo esse fato, 
porque, como pesquisadora, fui à Secretaria responsável pela feitura do regimento geral, pelo menos dez vezes, durante esses quatro anos de minha pesquisa e esse nunca foi feito. Já o RIUI, que deveria fazer parte do regimento geral, assim como o RICM, faz parte do Regulamento dos CM, está incompleto e ultrapassado. Ora, como reger Unidades de Internação com regimentos incompletos e defasados, seja da própria Unidade, que também está incompleto, seja um suposto regimento geral que deveria englobar todas as Unidades do DF? Note-se que a lacuna de um sistema de reeducação e ressocialização, que parece não funcionar, tem como base um regimento que não rege, pois não existe. Não existem, no Regimento Interno das Unidades de Internação do Distrito Federal, atribuições de funcionários, não se fala, de forma efetiva, em educação e profissionalização para os socioeducandos, nem se comenta a respeito da Lei antidrogas, o que parece ser um descaso com o sistema socioeducativo.

Ambos os regimentos, o Regimento Interno dos Colégios Militares e o Regimento Interno das Unidades de Internação, situam-se na cadeia de gêneros discursivos da ordem jurídica (as leis) e da ordem normativa (regimentos e normas). Além disso, podem ser considerados gêneros de governança, na medida em que são constituídos a partir de outros documentos legais. Desse modo, os regimentos desempenham o papel de ordenamento de determinada instituição.

\subsection{REGIMENTOS SOB A LUPA DO WORDSMITH TOOLS}

Nesta seção, serão apresentados os vinte processos mais recorrentes, por meio de lista, do Regimento das Unidades de Internação e do Regimento dos Colégios Militares. Essas listas foram elaboradas com o auxílio do uso do wordlist para a análise do sistema de transitividade. A Tabela é organizada em quatro colunas: a primeira apresenta a numeração dos processos em ordem crescente; a segunda contém os processos ordenados da maior frequência para a menor; a terceira coluna mostra o número de vezes de aparecimento no regimento; e a quarta apresenta as formas como os processos se materializam no texto ${ }^{23}$.

\footnotetext{
${ }^{23}$ Foram escolhidos os vinte processos mais recorrentes devido à carga semântica de cada um em termos de representação social.
} 


\subsubsection{Componentes da transitividade dentro do Regimento Interno das Unidades de Internação}

Nesta subseção, serão analisados os processos mais recorrentes do Regimento Interno das Unidades de Internação. A Tabela 4.5, abaixo, apresenta os processos (verbos) mais recorrentes no Regimento Interno das Unidades de Internação. Apreciemos.

Tabela 4.5 - Processos mais frequentes no Regimento Interno das Unidades de Internação

\begin{tabular}{llll}
\hline $\mathbf{N}$ & word & Freq. & Lemmas \\
\hline $\mathbf{1}$ & Ser & 128 & $\begin{array}{l}\text { Ser[47] são[27] é[16] será[15] serão[15] seja[3] serem[3] } \\
\text { sejam[1] sendo[1] }\end{array}$ \\
$\mathbf{2}$ & Dever & 57 & Deverá[24] deve[3] deverão[16] devendo[9] devem[5] \\
$\mathbf{3}$ & Ter & 33 & $\begin{array}{l}\text { Ter[17] têm[3] tenha[1] terão[1] terá[5] tem[2] tendo[2] } \\
\text { tenham[2] }\end{array}$ \\
$\mathbf{4}$ & Poder & 20 & Poderá[10] podendo[2] podem[1] possam[1] poderão[6] \\
& Realizar & 19 & $\begin{array}{l}\text { Realiza[2] realizadas[3] realizar[7] realizará[1] realizada } \\
\text { [1] realizado[4] realizados[1] }\end{array}$ \\
& & & \\
$\mathbf{6}$ & 12 & $\begin{array}{l}\text { Esteja[1] estiverem[1] está[2] estão[2] estar[2] estiver[2] } \\
\text { estejam[2] }\end{array}$
\end{tabular}

\begin{tabular}{llll}
$\mathbf{7}$ & Participar & 12 & Participar \\
$\mathbf{8}$ & Receber & 11 & Receber [10] receberam[1] \\
$\mathbf{9}$ & Respeitar & 9 & Respeita[3] respeitando[5] respeitarão[1] \\
$\mathbf{1 0}$ & Desenvolver & 6 & Desenvolver[4] desenvolverá[1] desenvolvendo[1] \\
$\mathbf{1 1}$ & Identificar & 6 & Identificar[6] identificada[1] \\
$\mathbf{1 2}$ & Manter & 6 & Manter[6] mantém[1] \\
$\mathbf{1 3}$ & Utilizar & 6 & Utilizar[3] utilizando[1] utilizando-se[1] utilizados[1] \\
\hline
\end{tabular}




\begin{tabular}{llll}
\hline $\mathbf{N}$ & word & Freq. & Lemmas \\
\hline $\mathbf{1 4}$ & Orientar & 5 & Orientar[4] orientando[1] \\
$\mathbf{1 5}$ & Aplicar & 5 & Aplicada[5] \\
$\mathbf{1 6}$ & Acompanhar & 5 & Acompanhar[5] acompanha-los[5] \\
$\mathbf{1 7}$ & Encaminhar & 5 & Encaminhar[5] \\
$\mathbf{1 8}$ & Estabelecer & 5 & Estabelecer[4] estabelecidas[1] \\
$\mathbf{1 9}$ & Permanecer & 4 & Permanecer[4] \\
$\mathbf{2 0}$ & Fornecer & 4 & Fornecer[3] fornecida[1] \\
\hline
\end{tabular}

Fonte: elaborado pela autora com dados do RIUI

A Tabela 4.5 apresenta os principais processos do RIUI. Como se pode observar, os processos mais frequentes, de acordo com a leitura do Wordlist, são: ser (128), dever (57), ter (33) e poder (20). Essa recorrência também pode ser visualizada no Gráfico 4.5. Esse gráfico apresenta somente os doze processos mais frequentes, uma vez que os sete últimos processos apresentam $1 \%$ de frequência e os demais processos apresentam menos de $1 \%$ de frequência.

\section{Gráfico 4.5 - Processos mais frequentes no RIUI}

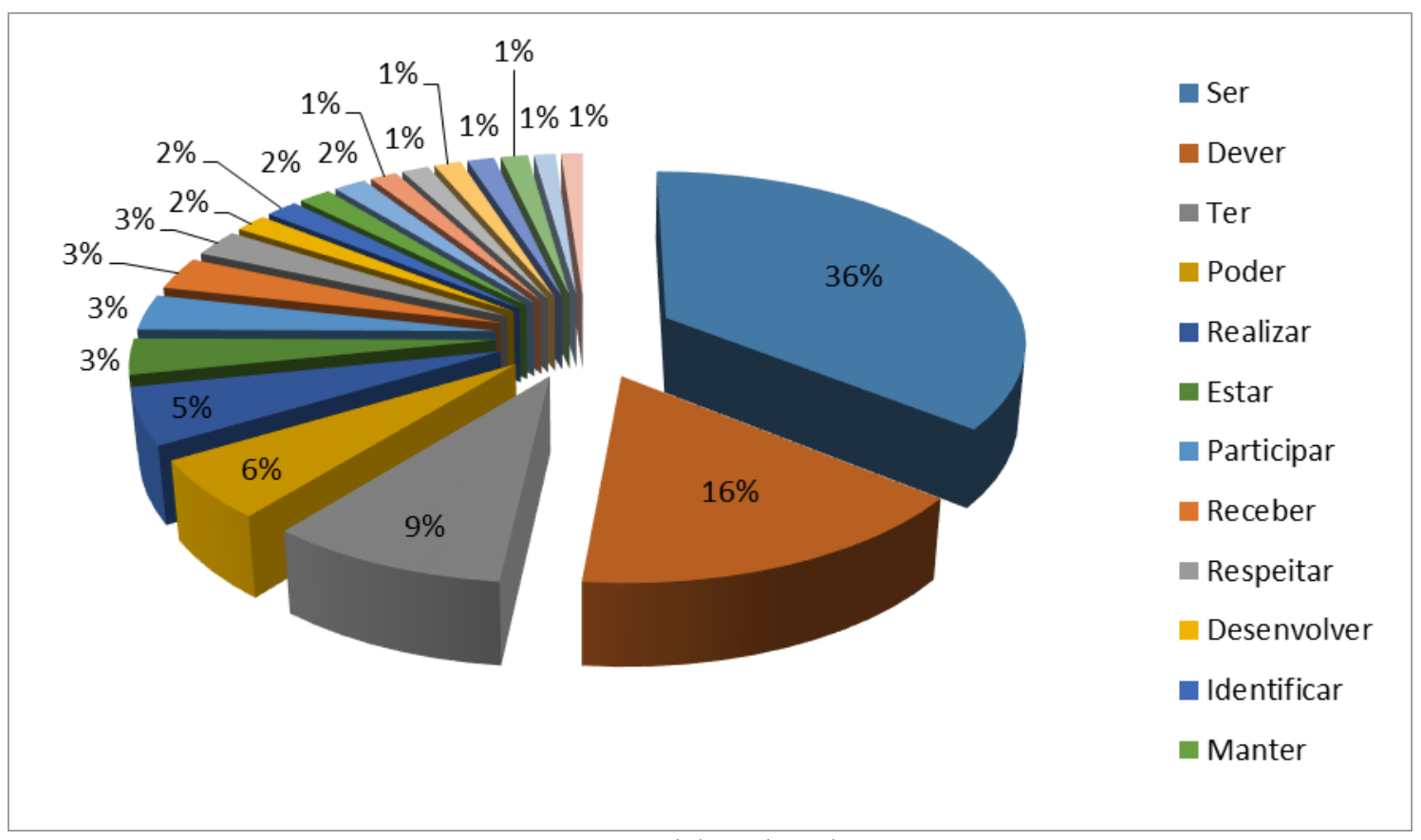

Fonte: elaborado pela autora 
O Gráfico 4.5, acima, mostra que o processo mais recorrente no RIUI é o "ser", o que indica uma estrutura com processos relacionais e ocorrências de voz passiva. Pode-se observar, também, os processos “dever", "ter" e "poder", o que faz a alusão às categorias de modalidade e modulação, na manifestação da metafunção interpessoal.

A ação do mundo físico mais recorrente no Regimento Interno das Unidades de Internação é o processo realizar, com 19 ocorrências, vindo a seguir o processo participar, com 12 ocorrências e, logo após, o processo receber, com 11 ocorrências. Nota-se, dessa forma, uma maior preocupação com as ações do mundo físico, ou seja, do fazer e do acontecer. A seguir, veremos os componentes do sistema de transitividade presentes no Regimento Interno das Unidades de Internação.

\subsubsection{A REPRESENTAÇÃO DAS AÇÕES E O SISTEMA DE TRANSITIVIDADE NO REGIMENTO INTERNO DAS UNIDADES DE INTERNAÇÃO}

Nesta subseção, serão analisados os componentes de transitividade presentes no RIUI. Destarte, foi feito o levantamento dos processos presentes no documento após a exclusão dos vocábulos que não eram processos verbais. Essa classificação segue as orientações metodológicas da Gramática Sistêmico-Funcional, o que permitiu constatar o seguinte resultado: 516 processos, sendo 78,68\% de ocorrências de processos materiais (409), 11,43\% de processos relacionais (59), 5,04\% de processos mentais (26), 4,07\% de processos verbais (22), nenhum processo existencial e nenhum comportamental. A distribuição dos processos do texto está sintetizado no Gráfico 4.6. 
Gráfico 4.6 - Distribuição de processos no RIUI

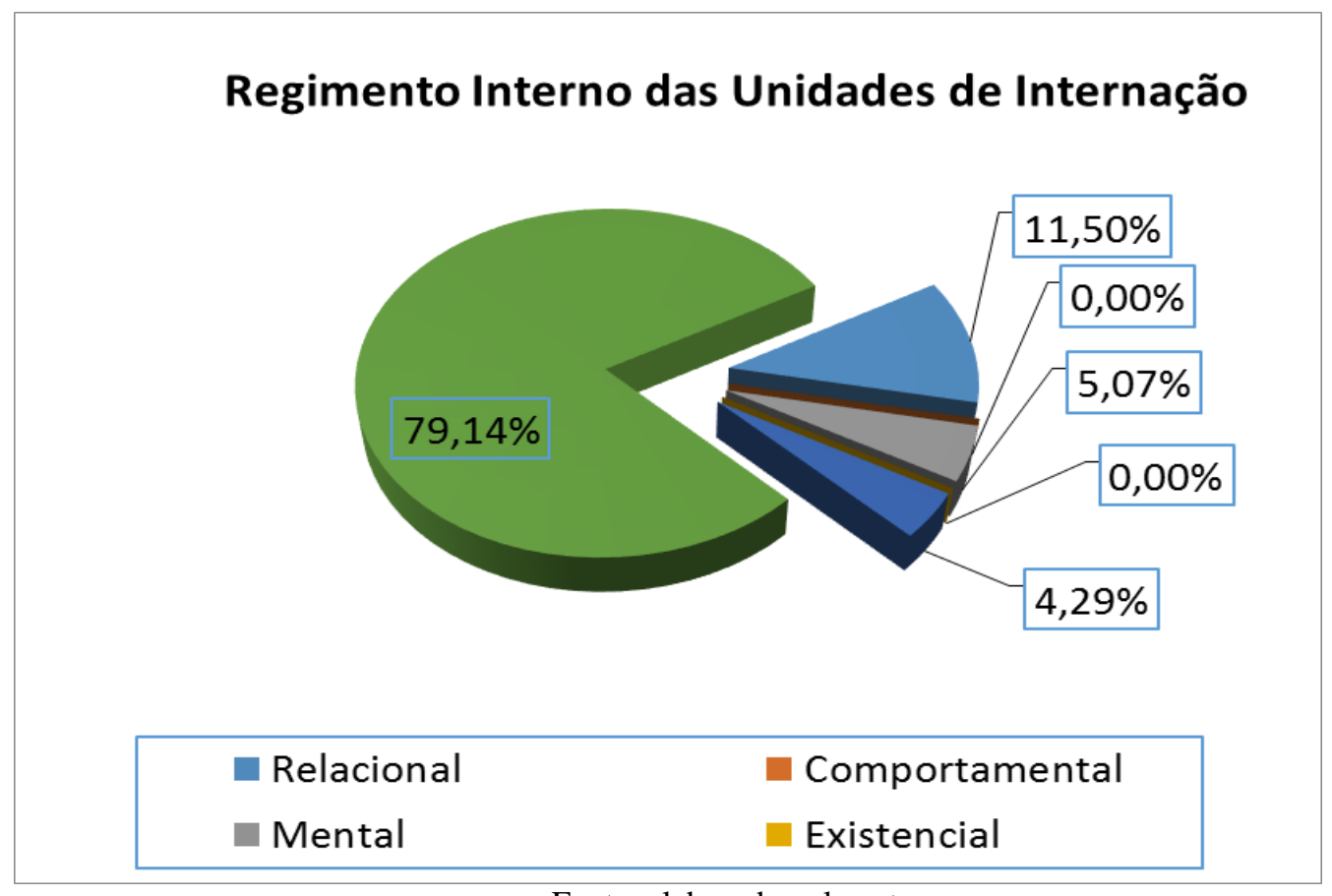

Fonte: elaborado pela autora

Observa-se que, no Gráfico 4.6, imperam os processos materiais, sendo mais da metade do total de processos do RIUI, o que pode ser explicado devido ao gênero textual Regimento analisado. Portanto, o que pertence ao mundo físico do fazer e do acontecer pode ser encontrado. Nos fragmentos a seguir, serão ilustradas como essas ações são representadas no Regimento.

(31) Artigo 27 - Providenciar o ingresso e matrícula na Instituição que está localizada na Unidade de Internação, de acordo com portaria conjunta Secretaria da Criança/Secretaria de Educação e, realizar [Processo material] o acompanhamento e a frequência e o rendimento escolar[Meta].

(Regimento Interno das Unidades de Internação do DF, Capítulo V Das Políticas Sociais, Seção III - Da Assistência à Escolarização, 2013, p.18)

(32) Artigo 36 - Estabelecer parcerias para realizar [Processo material] atendimentos terapêuticos sistemáticos para os adolescentes [Meta].

(Regimento Interno das Unidades de Internação do DF, Capítulo V Das Políticas Sociais, Seção IV - Da Assistência à Saúde 2013, p.19) 
Nos fragmentos (31) e (32), é destacado o processo material realizar, um processo do mundo do acontecer, que designa ações. Esse processo está integrando o capítulo referente às políticas sociais do Regimento Interno das Unidades de Internação. O excerto (31) diz respeito à assistência à escolarização e sinaliza a obrigatoriedade de, na Unidade de Internação, haver uma escola para que sejam realizados o acompanhamento e a frequência e $o$ rendimento escolar. Porém, cabe ressaltar que parecem não existir, em todas as Unidades de Internação, escolas com os ensinos fundamental e médio, como se pode observar no relato abaixo de um socioeducando.

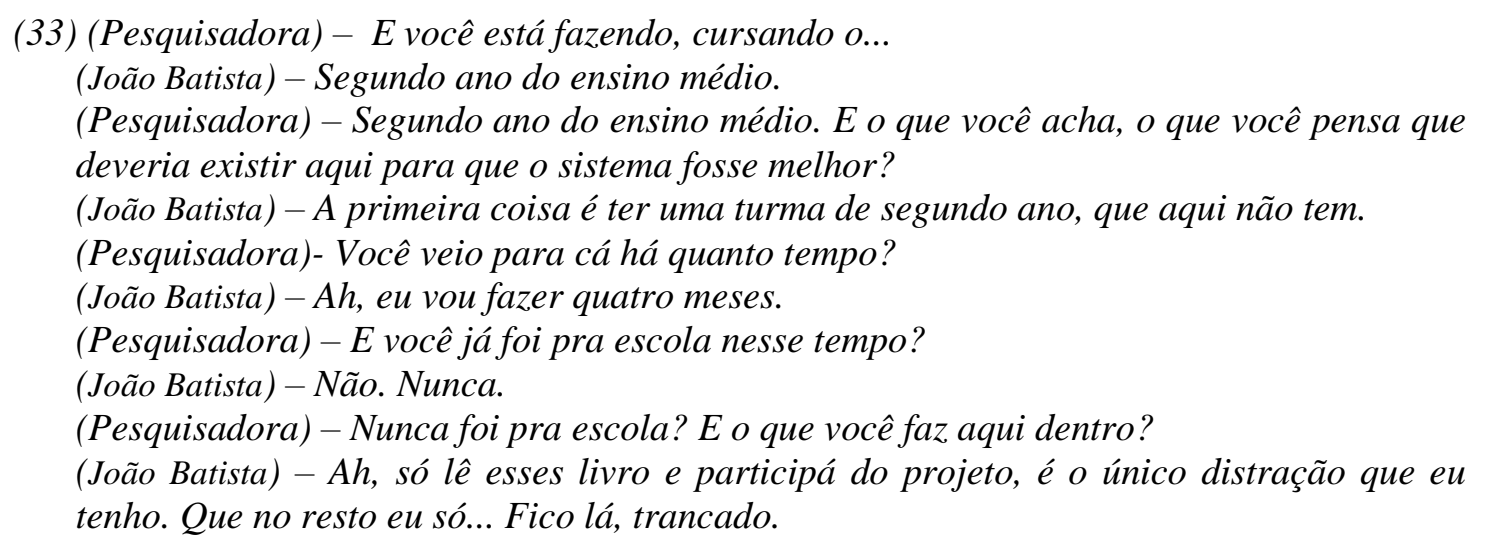

(UISM, relato de João Batista, 16a)

O relato de João Batista, no excerto (33), demostra que a ação de educar, que deveria estar sendo praticada, na Unidade de Internação, não está ocorrendo. Nessa direção, Carvalho (2011) lembra que, quando se fala em educação dentro do presídio e, neste caso dentro das Unidades de Internação, a complexidade do processo educacional fica bem evidente, pois parece não haver "incentivo efetivo por parte do governo e também por parte da sociedade em geral para a melhoria das condições inerentes à aplicação educacional voltadas para o aprendizado" (CARVALHO, 2011, p. 29). Da mesma forma, ocorre no excerto (34), em que as ações terapêuticas, referidas no RIUI, concernentes às políticas sociais de assistência à saúde, não são colocadas em prática, como se pode observar abaixo no relato de uma pedagoga da UISM.

(34) A equipe técnica é uma equipe muito boa, profissionais muito bons! Então, nós temos uma equipe que é::::Um jovem, ele teria que ter garantida aqui três especialidades, três especialistas, né? Que é o Pedagogo, o Psicólogo, o Assistente Social. [...] O jovem não é atendido pelos três, muitas vezes é só por um! Ou só um psicólogo, ou só um pedagogo, ou então, já há uma falha ali! A secretaria não consegue fornecer uma equipe realmente, 
pra aquele menino! Integrada, integral! Ele tem um atendimento ou dois, igual aqui, agora, agora com o novo contrato, é que é possivel atender dois especialistas que é o Pedagogo e o Psicólogo, ou então o Pedagogo e o Assistente Social. Sempre o Pedagogo junto, mas, ou Psicólogo ou Assistente.

(Relato de uma Pedagoga da Unidade de Internação de Santa Maria)

Pode-se notar, no excerto (34), que o relato da pedagoga põe à prova a ação do processo material realizar, pois se percebe a precariedade dos atendimentos terapêuticos sistemáticos para os adolescentes. Dessa forma, o processo material realizar, um processo do mundo do acontecer, que designa ações, torna-se descaracterizado, pois suas Metas, observadas nos excertos (31) e (32), quais sejam, o acompanhamento e a frequência e o rendimento escolar e os atendimentos terapêuticos sistemáticos para os adolescentes determinam o que deveria acontecer dentro da Unidade de Internação, mas que, na prática, não acontece. Como a ocorrência dos processos materiais foi bem maior que a dos outros processos no texto, buscou-se desenvolver um estudo mais apurado, como veremos a seguir no Gráfico 4.7.

\section{Gráfico 4.7 - Processo material Concreto e Abstrato no RIUI}

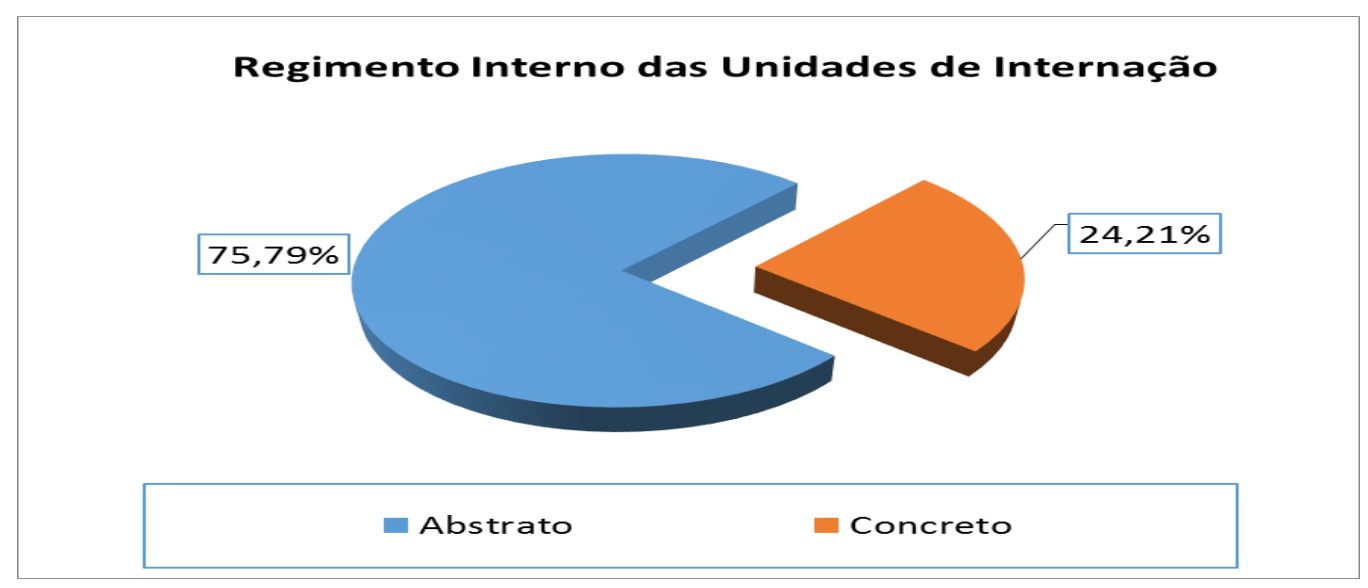

Fonte: elaborado pela autora

Observa-se que, no Gráfico 4.7, há 24,21\% de processo material concreto e 75,79\% de processo material abstrato $^{24}$. Dessa forma, as ações do "mundo físico", na maioria das

\footnotetext{
${ }^{24}$ De maneira geral, os processos materiais concretos são mudanças que ocorrem no mundo material e que podem ser percebidos como um movimento no espaço ou mudanças nos estados físicos das coisas. Já os processos materiais abstratos servem de modelo para construir mudanças que têm lugar em fenômenos abstratos (GHIO; FERNANÁNDEZ, 2008, p. 100)
} 
ocorrências no texto, indiciam o que ainda será realizado no "mundo do fazer", porque estão mais no nível da abstração do que da concretude de realização, como veremos abaixo.

(35) Art. 12 - São deveres do socioeducando em cumprimento de medida socioeducativa de Internação, entre outros:

$X$ - conhecer e praticar as normas e rotinas da Unidade de Atendimento;

XII- evitar palavras de baixo calão, expressões desrespeitosas, gestos obscenos, brincadeiras de mau gosto (risco), agressões físicas ou verbais contra autoridades, servidores, parceiros, visitantes e demais socioeducandos;

(Regimento Interno das Unidades de Internação do DF, Capítulo II Dos Direitos, Deveres e Estímulos, Seção I Dos Direitos, Deveres e

Estímulos aos socioeducandos, 2013, p.10-11)

O excerto (35) aponta as obrigações e instruções a serem seguidas pelos socioeducandos dentro da Unidade de Internação. Cabe destacar a peculiaridade das escolhas dos processos conhecer, praticar, evitar. No inciso X, os processos conhecer e praticar, na tessitura semântica de complementaridade textual, reportam-se à conscientização do socioeducando. Por isso, o que merece ser considerado é a direção voltada para a natureza cognitiva, que vai do processo mental ao processo material abstrato, acarretando, dessa forma, os mundos do pensar e do agir. Já a escolha do processo material abstrato evitar, no inciso XII, no segmento oracional, evitar palavras de baixo calão, expressões desrespeitosas, gestos obscenos, brincadeiras de mau gosto (risco), agressões físicas ou verbais contra autoridades, servidores, parceiros, visitantes e demais socioeducandos, indica a não proibição de ações desrespeitosas e perigosas, como agressões físicas ou verbais, o que vai de encontro à boa conduta do socioeducando.

Note-se que há um hiato na carga semântica desses processos materiais abstratos, na medida em que não se estabelece a real concretude das ações, pois não se sabe quais são as normas. Além disso, cabe ressaltar que as ações, as quais estão no campo da abstração, devido ao fator temporal, são ações que possuem um grau de incerteza, pois ainda poderão (ou não) ocorrer. Vejamos.

(36) Art. 20 - O acolhimento será feito [processo material abstrato] pela Equipe de Referência do socioeducando, preferencialmente após a recepção, ou o mais breve possivel. Se esta se der em final de semana ou feriado, o socioeducando deverá ser atendido [processo material abstrato] pela equipe de plantão presente abrigado em alojamento específico e encaminhado à Equipe de Referência no primeiro dia útil subsequente. 
(Regimento Interno das Unidades de Internação do DF, Capítulo III Da Recepção, Do Acolhimento, Do Plano Individual De Atendimento, Seção II Da Recepção e do Acolhimento, 2013, p.14)

No excerto (36), pode-se ver a presença dos processos materiais será feito e deverá ser atendido. Esses componentes verbais se encontram em grau de abstração, pois toda a ação de acolhimento do socioeducando ainda irá ocorrer. Ambos estão na voz passiva e apresentam a Equipe de Referência e a equipe de plantão, respectivamente, como Atores explícitos, o que acontece na maioria das construções passivas no decorrer do texto.

Em menor proporção, mas em evidência, são encontrados no Regimento Interno das Unidades de Internação os processos materiais concretos. Nos excertos (37) e (38), os processos realizar, atuar, praticar e agredir designam ações concretas do mundo do fazer, por isso são processos materiais concretos, como veremos abaixo:

(37) Art. $6^{o}-$ VI-Especialistas c - Psicólogo(a) - O profissional dessa área realiza atendimentos sistemáticos, em que são trabalhadas questões como estabelecimento e aprimoramento do vínculo emocional do socioeducando com a Unidade e familiares; engajamento na Medida Socioeducativa; conflitos próprios da adolescência; auto-estima; e orientação quanto ao comportamento na unidade e nos demais espaços de execução da medida. Atua, também, na prevenção do uso de substâncias psicoativas e aprimoramento do relacionamento com os familiares por meio de atendimentos sistemáticos, visitas institucionais e visitas domiciliares.

(Regimento Interno das Unidades de Internação do DF, Capítulo I Das Disposições Gerais, Seção IV - Dos Servidores, 2013, p.6)

No excerto (37), as ações concretas são atribuídas ao participante. Nesse viés, o(a) psicólogo(a) aparece como o Ator que realiza as ações. Já os atendimentos sistemáticos, bem como o enunciado na prevenção do uso de substâncias psicoativas e aprimoramento do relacionamento com os familiares são as Metas, que demonstram as ações atribuídas ao participante.

(38) Artigo 88 - São transgressões graves, dentre outras:

II - Induzir ou instigar alguém a praticar falta disciplinar grave;

III - agredir fisicamente qualquer pessoa;

(Regimento Interno das Unidades de Internação do DF, Capítulo VII Do Regulamento Disciplinar, Seção II - Das Transgressões, 2013, p.30) 
Os componentes verbais praticar e agredir, no excerto (38), também são processos materiais concretos. Entretanto, há, em ambos os casos, a omissão do Ator, qual seja, o socioeducando.

Nesse olhar sistêmico-funcional, será apresentado, a seguir, o Regimento Interno dos Colégios Militares, a fim de que se possa fazer um estudo comparativo entre os dois regimentos.

\subsubsection{Componentes verbais mais frequentes no Regimento Interno dos Colégios Militares}

Nesta subseção, serão analisados os processos mais recorrentes do Regimento Interno dos Colégios Militares. A Tabela 4.2, abaixo, apresenta os processos (verbos) mais recorrentes no Regimento Interno das Unidades de Internação. Apreciemos.

\section{Tabela 4.6 - Processos mais frequentes no Regimento Interno dos Colégios Militares}

\begin{tabular}{|c|c|c|c|}
\hline $\mathbf{N}$ & word & Freq. & Lemmas \\
\hline 1 & Ser & 221 & $\begin{array}{l}\text { Ser [50] são[24] é[46] será[45] serão[31] seja[1] } \\
\text { serem[4] sejam[3] sendo[17] }\end{array}$ \\
\hline 2 & Ter & 69 & $\begin{array}{l}\text { Ter [8] têm [6] tenha [7] terão [4] terá [8] tem [22] } \\
\text { tenham [6] terão[4] }\end{array}$ \\
\hline 3 & Estar & 51 & $\begin{array}{l}\text { Estejam [4] estiverem [1] está [13] estão [17] estar [4] } \\
\text { estiver [2] esteja [4] estará [5] }\end{array}$ \\
\hline 4 & Dever & 50 & $\begin{array}{l}\text { Deverá [17] deve [11] deverão [13] devendo [5] devem } \\
\text { [4] }\end{array}$ \\
\hline 5 & Considerar & 31 & $\begin{array}{l}\text { Considerado [20] considerada [5] consideradas [2] } \\
\text { considerados [1] considerando [1] }\end{array}$ \\
\hline 6 & Poder & 25 & $\begin{array}{l}\text { Possam [1] poderá [11] poderão [11] podendo [1] poder } \\
\text { [1] }\end{array}$ \\
\hline 7 & Realizar & 19 & Realiza [1] realizadas [1] realizar [16] realizados [1] \\
\hline 8 & Planejar & 18 & Planejar [16] planejará [1] planejados [1] \\
\hline 9 & Organizar & 17 & $\begin{array}{l}\text { Organizar [11] organiza [1] organizada[2] } \\
\text { organizadas[1] organizado[1] organizando[17] }\end{array}$ \\
\hline 10 & Apresentar & 12 & $\begin{array}{l}\text { Apresentar [9] apresentando [1] apresentada [1] } \\
\text { apresentadas [1] apresentado [1] apresentarem [1] } \\
\text { apresente [1] apresentem[1] }\end{array}$ \\
\hline
\end{tabular}




\begin{tabular}{llll}
\hline $\mathbf{1 1}$ & Manter & 17 & $\begin{array}{l}\text { Manter [12] mantém [2] mantendo [1] mantenha [1] } \\
\text { mantidos [1] }\end{array}$ \\
$\mathbf{1 2}$ & Orientar & 15 & $\begin{array}{l}\text { Orientar [10] orientando [2] orientam [2] orientem [1] } \\
\text { Cabe [10] cabendo [2] cabem [1] }\end{array}$ \\
$\mathbf{1 4}$ & Caber & 13 & $\begin{array}{l}\text { Compreende [4] compreender [2] compreendendo [3] } \\
\text { Compreendida [3] }\end{array}$ \\
$\mathbf{1 5}$ & Fazer & 11 & Fazer [5] fazendo [1] fará [2] faz [1] feito [1] feita [1] \\
$\mathbf{1 6}$ & Orientar & 10 & Orientar [10] \\
$\mathbf{1 8}$ & Apresentar & 9 & Apresentar [9] \\
$\mathbf{1 9}$ & Funcionar & 9 & Funcionar [ 9] \\
$\mathbf{2 0}$ & Haver & 9 & Haverá [3] há [2] haver [2] houver [1] havendo [1] \\
\hline
\end{tabular}

Fonte: elaborado pela autora com dados do RICM

A tabela 4.6 apresenta os principais processos do RICM. Como se pode observar, os processos mais frequentes, de acordo com a leitura do Wordlist, são: ser (221), ter (69), estar (51) e dever (50). Essa recorrência também pode ser visualizada no Gráfico 4.8. Esse gráfico apresenta somente os vinte processos mais frequentes, uma vez que os quatro últimos processos apresentam $1 \%$ de frequência.

\section{Gráfico 4.8 - Processos mais frequentes no RICM}

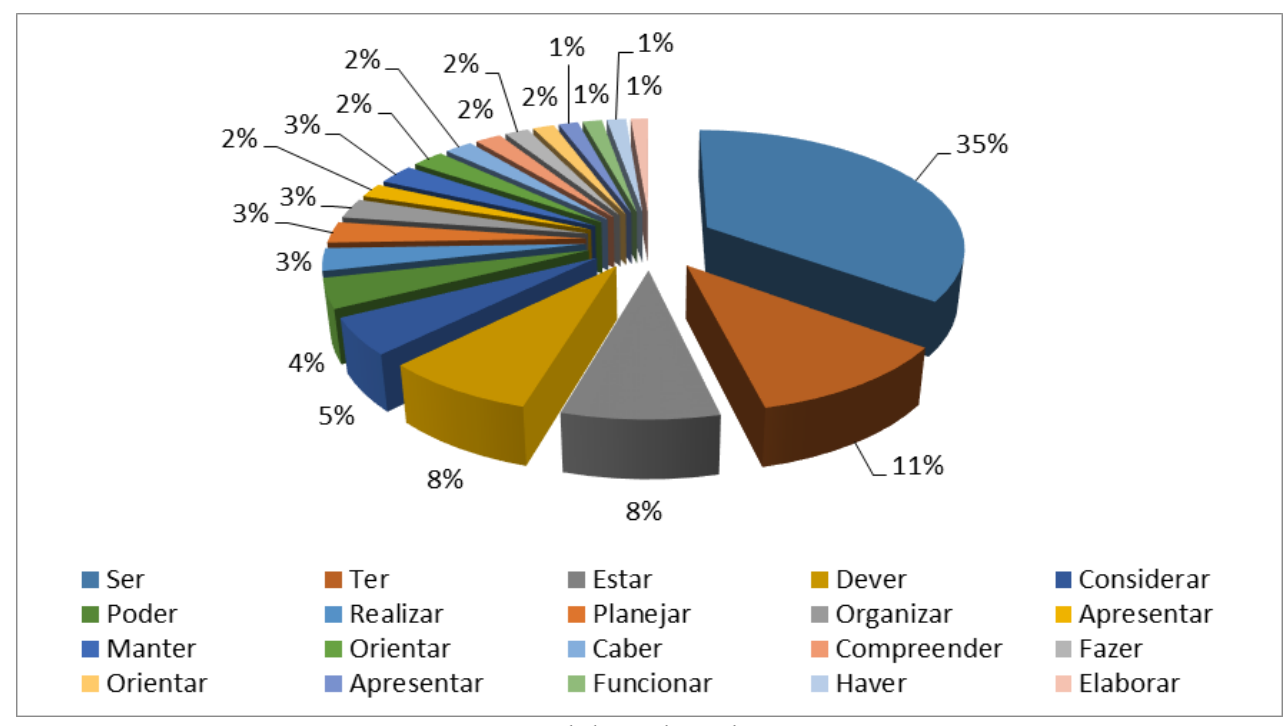

Fonte: elaborado pela autora 
O Gráfico 4.8 mostra que o processo que mais aparece no RICM é o "ser", o que indica uma estrutura com processos relacionais e ocorrências de voz passiva. Pode-se observar, também, os processos ter, estar e dever, o que faz a alusão às categorias de modalidade e modulação, na manifestação da metafunção interpessoal.

A ação do mundo mental mais recorrente no Regimento Interno das Unidades de Internação é o processo considerar, com 31 ocorrências, vindo a seguir o processo poder, com 25 ocorrências e, logo após, o processo realizar, com 19 ocorrências. Nota-se que, no Regimento Interno dos Colégios Militares, existe a preocupação com as ações do mundo mental, ou seja, da experiência do mundo na consciência, apesar de haver mais ocorrências de processos materiais no texto. Pode-se inferir, dessa forma, que, a escolha lexical de processos mentais deixa o regimento mais humanizado, focado no sujeito que sente, pensa, percebe e deseja. A seguir, veremos os componentes do sistema de transitividade presentes no Regimento Interno dos Colégios Militares.

\subsubsection{A REPRESENTAÇÃO DAS AÇÕES E O SISTEMA DE TRANSITIVIDADE NO REGIMENTO INTERNO DOS COLÉGIOS MILITARES}

Nesta subseção, serão analisados os componentes de transitividade presentes no RICM. Para tanto, foi feito o levantamento dos processos presentes no documento após a exclusão dos vocábulos que não eram processos verbais. Essa classificação segue as orientações metodológicas da Gramática Sistêmico-Funcional, o que permitiu constatar o seguinte resultado: 983 processos, sendo 73,09\% de ocorrências de processos materiais (717), $12,84 \%$ de processos relacionais (126), 10,91\% de processos mentais (107), 2,45\% de processos verbais (24), $0,71 \%$ de processos existenciais (9) e nenhum processo comportamental. A distribuição dos processos do texto está sumarizada no Gráfico 4.9. Apreciemos. 


\section{Gráfico 4.9 - Distribuição de processos no RICM}

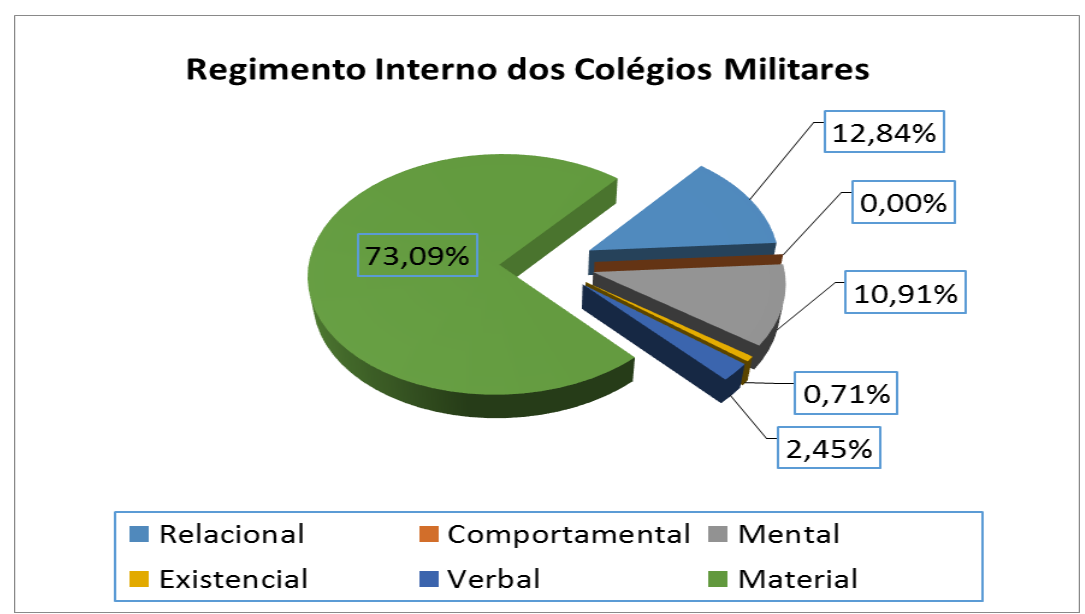

Fonte: elaborado pela autora

No Gráfico 4.9 os processos materiais são os que mais ocorrem, sendo mais da metade do total de processos do RICM, o que pode ser explicado devido ao gênero textual Regimento analisado. Portanto, o que pertence ao mundo físico do fazer e do acontecer pode ser encontrado no Regimento. Entretanto, cabe destacar que, embora o processo material apareça em grande quantidade, o processo mental se destacou no documento, pois foi notado um olhar mais acurado para os alunos. Os fragmentos abaixo ilustram essa escolha no Regimento Interno.

(39) Art. $4^{\circ}$ Os fundamentos que compõem a sua proposta pedagógica são:

IV - estimular no aluno o desenvolvimento de atitudes crítico-reflexivas, espírito de investigação, criatividade, iniciativa e respeito às diferenças individuais, conduzindo-os a aprender a aprender e aprender a pensar;

$V$ - conduzir o aluno a compreender o significado das áreas de estudo e das disciplinas, enquanto participante do processo histórico da transformação da sociedade e da cultura, desenvolvendo a sua autonomia, valorizando o conhecimento prévio, suas experiências e as relações professor-aluno e aluno-aluno, conscientizando-os de que a aprendizagem adquirida é mais importante que a avaliação educacional de aferição escolar; $e$

VI - desenvolver no aluno atitudes, valores e hábitos saudáveis à vida em sociedade, num ambiente no qual todos possam:

a) compreender e respeitar os direitos e deveres da pessoa humana, do cidadão patriota, da família, dos grupos sociais, do estado e da nação brasileira.

(Regimento Interno dos Colégios Militares, Título I Do Estabelecimento De Ensino, Dos Princípios e Das Finalidades, Capítulo II Dos Princípios, Das Finalidades e Dos Fundamentos, 2011, p.2)

No excerto (39), nota-se a preocupação com a construção da experiência do aluno. Isso fica evidenciado com as escolhas dos processos aprender, pensar, compreender $e$ conscientizar, no sentido em que se pretende estimular, no adolescente, atitudes críticoreflexivas e conscientizá-lo da importância da aprendizagem e do respeito consigo mesmo e 
com o próximo. Além disso, observe-se a ocorrência do processo considerar utilizado, na maioria dos casos, no RICM, na voz passiva. Vejamos.

(40) Art. 105. Além daquelas constantes dos documentos citados no artigo anterior, são devidas ao aluno as seguintes formas de recompensa:

$\S 1^{\circ}$ É considerado "aluno-destaque" aquele que obtiver Nota Periódica (NP) igual ou superior a 8,0 (oito vírgula zero ou menção MB) em todas as áreas de estudo ou disciplinas do seu ano e no bimestre considerado, bem como em Educação Física demonstrando alto rendimento nos estudos e tornando-se exemplo para seus pares.

(Regimento Interno dos Colégios Militares, Título IX Do Corpo Discente, Capítulo III Dos Deveres e Direitos dos Alunos, 2011, p.38)

(41) Art. 124. É considerado aprovado o aluno que atingir todos os Objetivos de Instrução Individual (OII), da ficha constante no Programa Padrão de Instrução utilizado pelo curso.

(Regimento Interno dos Colégios Militares, Título IX Do Corpo Discente, Capítulo VIII Do Curso de Formação Reservista, 2011, p.42)

Nos excertos (40) e (41), há dois casos do processo mental considerar na voz passiva, em: É considerado "aluno-destaque" aquele que obtiver Nota Periódica (NP) igual ou superior a 8,0 e em É considerado aprovado o aluno que atingir todos os Objetivos de Instrução Individual (OII). A respeito da voz passiva, Thompson (2004) lembra que quando se faz uso da dessa voz, há uma quebra de constituintes por uma razão particular. Nessa vertente, essa quebra, na língua portuguesa, afeta a relação entre papéis semânticos e relações gramaticais (SOUZA, 2015, p. 236), o que, nesses casos, acarreta uma posição pós-processo ou a omissão do agente (Experienciador) e a topicalização do fenômeno.

Ressalte-se que, como lembra Silveira (2008, p.228) a voz passiva é frequente nos gêneros da burocracia administrativa, principalmente, leis, estatutos, regulamentos, contratos e regimentos, ou seja, textos que fazem referência às provisões legislativas ${ }^{25}$.

Além dos processos mentais, o RICM é composto, em sua maioria, por processos materiais que designam as ações do "fazer e acontecer" no texto. Abaixo, podemos apreciar a estatística dos componentes do processo material: o abstrato e o concreto.

\footnotetext{
${ }^{25}$ Segundo Silveira (2008, p. 254), a expressão "provisões legislativas" é a tradução literal de legislative provisions, termo utilizado por Bhatia (1993, p. 101), cuja pesquisa tem sido direcionada também a alguns gêneros desta área.
} 


\section{Gráfico 4.10 - Processo material Concreto e Abstrato no RICM}

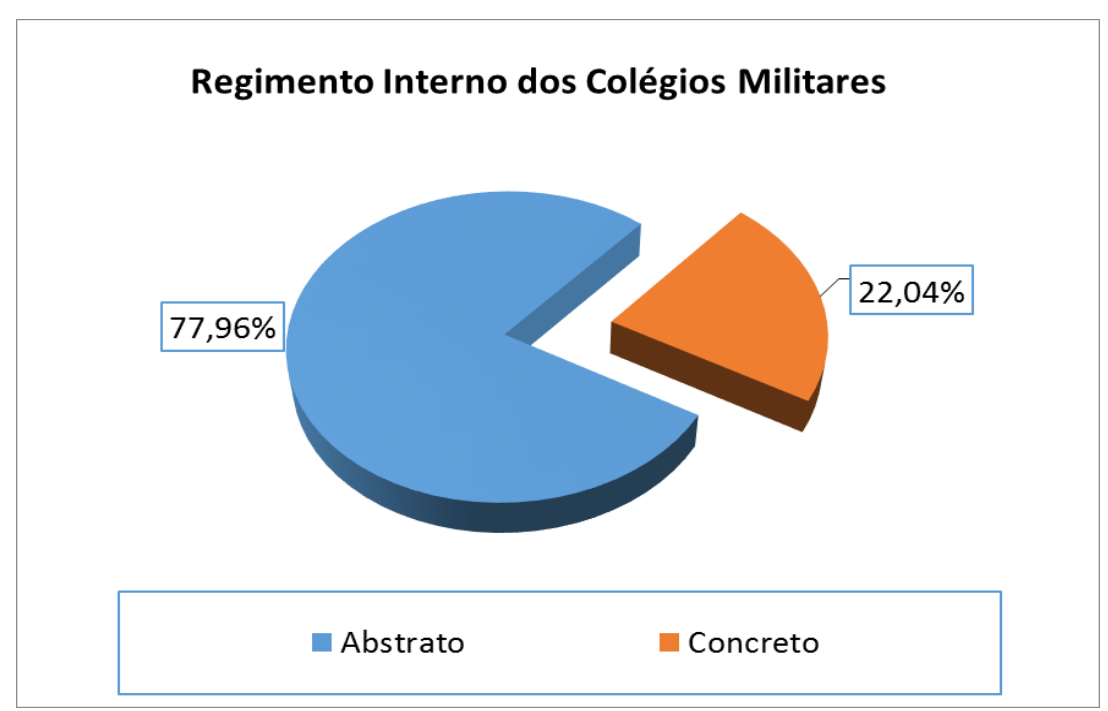

Fonte: elaborado pela autora

Constata-se, no Gráfico 4.10, a ocorrência de 24,38\% de processo material concreto e $75,62 \%$ de processo material abstrato. Sendo assim, os processos materiais podem estar no plano do real ou no plano das abstrações. No RICM, podem ser notadas tanto as mudanças onde acontecem fenômenos abstratos como também mudanças no mundo material e que podem ser constatadas como movimentos no espaço ou alterações nos estados físicos dos objetos (HALLIDAY; MATHIESSEN, 2004), como veremos nos fragmentos abaixo.

(42) Art. $4^{o}$ - Art. $4^{\circ}$ Os fundamentos que compõem a sua proposta pedagógica são:

II - capacitar [processo material abstrato] o aluno à absorção de conteúdos programáticos qualitativos e de pré-requisitos essenciais ao prosseguimento de seus estudos, com base no domínio da leitura, da escrita e das diversas linguagens utilizadas pelo homem, permitindo-lhe [processo material abstrato] analisar [processo mental], sintetizar [processo mental] e interpretar [processo mental] dados, fatos e cálculos, para resolver [processo material abstrato] situações problemas simples ou complexas, valorizando [processo material abstrato] o seu desenvolvimento pessoal.

(Regimento Interno dos Colégios Militares, Título I Do Estabelecimento De Ensino, Dos Princípios e Das Finalidades, Capítulo II Dos Princípios, Das Finalidades e Dos Fundamentos, 2011, p.2)

(43) Art. 19 - Além daquelas previstas no R-69, a SPscPed tem as seguintes atribuições: VII - pesquisar [processo material abstrato] os hábitos de estudo dos alunos e orientar [processo material abstrato] aqueles que apresentarem [processo material abstrato] dificuldades, buscando [processo material abstrato] junto à família o apoio necessário para solucionar essas dificuldades.

(Regimento Interno dos Colégios Militares, Título III Das Atribuições, Capítulo IV Da Subdireção De Ensino e Da Divisão De Ensino, Seção III - Da Seção Psicopedagógica, 2011, p.8) 
Os excertos (42) e (43) apresentam processos materiais abstratos, com as ações do mundo físico, capacitar, permitir, resolver, valorizar, apresentar, buscar, combinados ao processo mental. Essa combinação parece harmônica, nesses fragmentos, na medida em que se tenta direcionar as ações de forma positiva para o benefício do aluno. No RICM, identificam-se, também, diversos casos de progressões de ações, com processo material abstrato, como se pode observar nos excertos abaixo:

(44) Art. 17. Além daquelas previstas no R-69, o SDir Ens/Ch Div Ens tem as seguintes atribuições:

IV - planejar [processo mental], programar [processo material abstrato] e coordenar [processo material abstrato] a aplicação de avaliações educacionais (testes e provas formais), emitindo parecer técnico sobre resultados indesejáveis, logo após a correção pelos docentes, assessorando preventivamente a direção de ensino.

(Regimento Interno dos Colégios Militares, Título III Das Atribuições, Capítulo IV Da Subdireção De Ensino e Da Divisão De Ensino, Seção I- Das Disposições Gerais, 2011, p.6)

(45) Art. 19. Além daquelas previstas no R-69, a SPscPed tem as seguintes atribuições: VIII - planejar [processo mental], organizar [processo material abstrato] e coordenar [processo material abstrato] as reuniões de pais e mestres, após aprovação da pauta pela direção de ensino e reuniões com os coordenadores do ano escolar e o corpo de alunos;

(Regimento Interno dos Colégios Militares, Título III Das Atribuições, Capítulo IV Da Subdireção De Ensino e Da Divisão De Ensino, Seção III - Da Seção Psicopedagógica, 2011, p.8)

(46) Art. 21. As Seções de Ensino têm as seguintes atribuições:

I - coordenar [processo material abstrato], conduzir [processo material abstrato] $e$ avaliar [processo mental] a execução didático-pedagógica do ensino das disciplinas afins, sob sua responsabilidade.

(Regimento Interno dos Colégios Militares, Título III Das Atribuições, Capítulo IV Da Subdireção De Ensino e Da Divisão De Ensino, Seção I - Das Seções De Ensino, 2011, p.10)

(47) Art. 25. O assistente administrativo tem as seguintes atribuições:

II - planejar [processo mental], coordenar [processo material abstrato] e acompanhar [processo material abstrato] a execução das atividades atribuídas à divisão de pessoal, à seção de inteligência e operações, à seção de comunicação social, à seção de informática e à companhia de comando e serviços.

(Regimento Interno dos Colégios Militares, Título III Das Atribuições, Capítulo V Do Assistente Administrativo, 2011, p.11) 
Nos excertos (44), (45), (46) e (47), há uma sucessão de ações. Ressalte-se que a presença de processos materiais abstratos e de processos mentais parecem configurar a intenção de dar início e continuidade a determinada ação, de modo que essa ação seja finalizada e executada. No excerto (44), pode-se notar as escolhas dos processos planejar, programar e coordenar como um encadeamento de ações contínuas, assim como no (45), com planejar, organizar e coordenar; no (46), com coordenar, conduzir e avaliar; e no fragmento (47), com a sequência planejar e acompanhar.

Esse tipo de construção faz-se recorrente nas partes que se referem às atribuições do comandante, da seção técnica, do conselho de ensino, do subcomandante, da subdireção de ensino, da divisão de ensino, da seção psicopedagógica, da seção de supervisão escolar, da companhia de alunos e diversas outras seções. Essas escolhas lexicais sequenciais de ações contribuem para que cada membro da divisão de ensino e cada seção tome ciência de suas atribuições e funções com o propósito de executá-las e finalizá-las.

Além dos processos materiais abstratos, também foram encontrados, em menor número, o processo material concreto, como se pode observar nos fragmentos abaixo.

(48) Art. 127. É excluído e desligado do CFR o aluno que:

VII - por exclusão ou desligamento do CM no qual realiza [processo material concreto]o curso.

(Regimento Interno dos Colégios Militares, Capítulo VIII -

Do Curso de Formação de Reservista, 2011, p.42)

(49) Art. 13. Além daquelas previstas no $R-69$, o diretor de ensino tem as seguintes atribuições:

$V$ - homologar [processo material concreto] os pareceres dos conselhos de ensino e de classe, desde que atendam a legislação e as normas em vigor.

(Regimento Interno dos Colégios Militares, Título III - Das Atribuições, Capítulo I - Do Comandante E Diretor De Ensino, 2011, p. 5)

Observe-se que, nos excertos (48) e (49), os processos realizar e homologar estão no mundo físico das ações e do fazer, pois envolvem entidades que fazem algo e executam alguma ação, isto é, processos do fazer (EGGINS, 2004, p. 215). A particularidade que existe, porém, é que, nesses fragmentos, ocorrem as mudanças no mundo material para que os processos se tornem concretos. 


\subsubsection{Cotejo Parcial}

A análise dos processos do Regimento Interno das Unidades de Internação e do Regimento Interno dos Colégios Militares ilustra como dois documentos de mesmo gênero têm constituintes diversos. Isso ocorre, sobretudo, devido aos contextos diversificados em que estão inseridos. Sendo os gêneros aspectos discursivos das formas humanas de ação e interação em eventos sociais (FAIRCLOUGH, 2003, p. 65), envolvem formas particulares de relações sociais entre agentes sociais (indivíduos e organizações). Por isso, podem ser evidenciados processos diferentes, como se pode observar no Quadro comparativo do RICM e do RIUI abaixo.

\section{Quadro 4.4 - Quadro comparativo entre o RICM e o RIUI}

\begin{tabular}{|l|l|l|}
\hline Processo & RICM & RIUI \\
\hline Material & 717 & 406 \\
\hline Relacional & 126 & 59 \\
\hline Mental & 107 & 26 \\
\hline Verbal & 24 & 22 \\
\hline Existencial & 7 & 0 \\
\hline
\end{tabular}

Fonte: elaborado pela autora

Observa-se que, no Quadro 4.4, tanto no Regimento Interno dos Colégios Militares quanto no Regimento Interno das Unidades de Internação, os processos materiais se sobressaem. A alta ocorrência dos processos materiais é explicada devido ao gênero Regimento analisado. Nessa vertente, Eggins (2002, p. 338) lembra que o significado básico dos processos materiais consiste em uma determinada entidade que executa algo ou se encarrega de determinada ação, ou seja, parece que as Instituições corporificam as ações e decisões de forma hierárquica, avocando para si o poder institucional sobre a vida das pessoas.

Ademais, nos regimentos analisados, nota-se a presença do processo mental. Cabe destacar que as incidências desse processo são bem maiores no RICM, como se pode observar no Quadro anterior. Há 107 processos mentais no RICM contra 26 no RIUI. Resulta que o Regimento dos Colégios Militares torna-se, com isso, mais humanizado, pois o sujeito, no caso o estudante, é tratado como ser pensante, dotado de sentimentos e desejos. 
Já a ocorrência do processo verbal apareceu de forma equilibrada nos dois textos. No RICM, foram encontrados os processos incentivar, sugerir, informar, esclarecer, estimular, dentre outros. No RIUI, processos como entrevistar, solicitar, debater, discutir. Note-se, entretanto, que a carga semântica das escolhas lexicais dos processos envolvidos se distingue, pois, enquanto o primeiro incentiva, estimula, esclarece, o segundo solicita, entrevista, discute.

O processo relacional também é encontrado nos regimentos. Em ambos, observa-se a ocorrência do ser topicalizando o artigo abordado:

(50) Art. 111. São atribuições do oficial orientador:

I - orientar os trabalhos desenvolvidos no âmbito da agremiação, incentivando a participação dos seus integrantes;

II - fiscalizar os atos dos membros da diretoria, à luz do estatuto da agremiação, corrigindo-os quanto a eventuais desvios;

III - incentivar a ligação e a coordenação da agremiação com as suas congêneres; $e$

$I V$ - relatar ao Cmt CA, sistematicamente, as atividades desenvolvidas pela agremiação, destacando os resultados obtidos, as influências sobre seus integrantes $e$ as consequências decorrentes.

(Regimento Interno dos Colégios Militares, Capítulo V Das Agremiações Internas, 2011, p.7)

(51) Art. $14-\underline{\text { São }}$ estímulos coletivos:

I- o elogio por escrito em sua pasta de execução de medida;

II- participação em passeios, atividades esportivas e culturais promovidas ou apoiadas pela Unidade em ambientes externos aos da Unidade de Atendimento; que são realizadas de forma excepcional ou que não estejam previstas em seu PIA

III-outros.

(Regimento Interno das Unidades de Internação do DF, Capítulo II Dos Direitos, Deveres e Estímulos, Seção I - Dos Direitos, Deveres e

Estímulos aos Socioeducandos, 2013, p.12)

Os excertos (50) e (51) ilustram a existência de uma relação de atribuição realizada pelo processo ser. Em vários momentos, no decorrer de ambos os textos, ocorre a estrutura de Processo Relacional + Atributo, com o intuito de determinar conceitos, ou mesmo denominar e enumerar atribuições.

O processo comportamental não apareceu nos dois regimentos, pois não foram encontradas "características de atividades psicológicas e fisiológicas", que segundo O’Donnell, Zappavigna e Whitelaw (2008, p.3), são essencialmente comportamentais. Já o processo existencial só foi encontrado, em número bastante reduzido, no RICM, como é o caso do excerto (52), a seguir: 
(52) Parágrafo único: A duração do CFR é de meio ano letivo, com funcionamento previsto para o primeiro semestre letivo e sempre que houver [processo existencial] um efetivo mínimo de 20 candidatos.

As orações existenciais, conforme lembram Fuzer e Cabral (2014), apesar de ocorrerem em pequeno número nos discursos, comparadas aos outros processos, exercem um importante papel, de forma que em determinados textos, como peças processuais jurídicas e artigos científicos, é possível comprovar a existência ou não de seres, fenômenos, dados ou comportamentos.

A partir desses dois documentos, será feita, a seguir, uma análise comparativa, à luz da LSF e da ADC, de artigos com temas em comum dos regimentos dos Colégios Militares e das Unidades de Internação.

\subsection{ANÁliSe DOCUMENTAL DE ACORDO COM A LSF E A ADC}

Como sugerem Halliday e Hasan (1989), a linguagem tem como propriedade fundamental não só o uso que se faz dela, mas também a possibilidade de uma organização semântica do sistema. Por isso, existe a noção de que a linguagem é construída ou fundamentada em função dos significados experiencial/oração como representação/ ideacional, interpessoal/oração como troca e textual/oração como mensagem. Ressalte-se que o texto documental é a base deste trabalho, no sentido em que se busca interpretar a mensagem que perpassa por cada excerto analisado. Para tanto, a análise enfoca uma unidade de informação tanto como troca, quanto como representação na tessitura textual.

Já para a ADC, na função ideacional, o discurso contribui para a composição de sistemas de conhecimento e crença (ideologias), por meio da representação do mundo. Como já foi mencionado, a ADC, à luz da situação social e histórica de um texto, busca mostrar os padrões de crenças e valores que estão codificados na língua e que estão implícitos à mensagem. Sendo assim, analisar-se-á o texto em termos dos três significados, porque pactuo com o pensamento de Fairclough (2003) de que os três significados do discurso atuam simultaneamente em todos e qualquer enunciado e por isso será feita a análise, também, da forma como eles se apresentam nos excertos (vocabulário, gramática).

Sendo assim, conjugando-se a ADC e a LSF, será feito um percurso analítico com base em dois Regimentos: Regimento Interno das Unidades de Internação do Distrito Federal e Regimento Interno dos Colégios Militares. Porém, serão também analisados, o Guia do Aluno e do Responsável, que integra o Regimento do Colégio Militar e o Regimento Interno 
de Santa Maria. Nessa perspectiva, busca-se identificar, em termos de análise, os diferentes tipos de significados que são usados e como a linguagem é organizada para criar significados (Eggins, 2004), de acordo com o contexto, pois, para Halliday (1989), o princípio da multifuncionalidade é considerado fundamental para "uma interpretação funcional da linguagem”, como se pode observar nas análises dos fragmentos abaixo.

\subsubsection{Referência aos princípios}

Nesta subseção, a análise terá como tema central os princípios e finalidades do atendimento socioeducativo inseridos no Regimento Interno das Unidades de Internação, assim como dos Colégios Militares, prevista no Regimento do CM. Será feita uma exposição dos artigos 124 e 125 do Estatuto da Criança e do Adolescente contrapondo-se ao artigo $2^{\circ}$ do RIUI. Em seguida, serão tratados aspectos do artigo $3^{\circ}$ do Regimento dos CM. A seleção desses artigos foi feita para que possa ser mostrada a interpretação subjetiva a dedução do que poderá ou deverá ser cumprido no que se refere à lei, o que permite a observação do cruzamento dos eixos da possibilidade e da obrigatoriedade. Vejamos.

(53) Artigo $2^{\circ}-O$ atendimento [Ator] buscará garantir [processo material abstrato] a proteção integral dos direitos dos socioeducandos [Meta], por meio de um conjunto articulado de ações governamentais e não-governamentais, da União, Estado, Distrito Federal e dos Municípios [circunstância de meio], visando favorecer [processo material abstrato] o acesso aos direitos fundamentais, tais como, saúde, educação, profissionalização, trabalho, assistência social, esporte, cultura e lazer, dentre outros[Meta].

(Regimento Interno das Unidades de Internação do DF, Seção I - Do Objetivo e Princípios do Atendimento Socioeducativo, 2013, p.2)

No excerto (53), nota-se que o atendimento aos socioeducandos em cumprimento à medida socioeducativa provoca o desenrolar de dois processos materiais abstratos: buscará garantir e visando favorecer. Essas escolhas lexicais parecem ir à contramão dos artigos $124 \mathrm{e}$ 125, que serão analisados abaixo, do Estatuto da Criança e do Adolescente, que garantem, no tempo presente, o que o Regimento Interno das Unidades de Internação em seu artigo $2^{\circ}$ vislumbra no futuro. Isso pode ser sinalizado por se tratar de uma lacuna existente entre o RIUI no que concerne ao dispositivo legal e aos direitos dos adolescentes.

O hiato existente parece ocorrer devido aos processos selecionados buscará garantir e visando favorecer, formas verbais expressas em suas abstrações de um vir-a-ser em 
“dimensões temporais". ${ }^{26}$ O verbo, para Halliday (1985), pertence à esfera semântica das relações e dos processos (estados/eventos), sendo ele o responsável pela relação sintáticosemântica dos diferentes participantes. Nessa esteira, sugere Corôa (1985, p. 35) que os verbos '"são elementos linguísticos que mais de imediato situam a ação, estado, evento ou processo na sua relação temporal com a enunciação e o falante/ouvinte". Desse modo, pode-se argumentar que os processos do excerto (53), na função modo-temporal, não cumprem o papel de estabelecer, efetivamente, os direitos e as garantias assegurados ao socioeducando. Observe-se que, nos dois sintagmas verbais destacados, buscará garantir e visando favorecer predomina mais a intenção do que a ação. Essa lacuna dá margem ao não cumprimento efetivo da lei. Já as Metas, quais sejam, a proteção integral dos direitos dos socioeducandos e seus direitos fundamentais, apresentadas de forma exemplificativa, podem ser vistas como possibilidades de cumprimento ou do não cumprimento da norma.

Além disso, cabe ressaltar que, no segmento oracional visando favorecer o acesso aos direitos fundamentais, tais como, saúde, educação, profissionalização, trabalho, assistência social, esporte, cultura e lazer, dentre outros, há estratégias textuais-discursivas cujas expressões tais como e dentre outros, explicativa e exemplificativa, respectivamente, parecem remeter a opções que poderão disponibilizar um, todos ou nenhum direito, de acordo com a interpretação da norma, bem como a condição estrutural da instituição das Unidades de Internação. Pode-se sugerir, desse modo, que essas estratégias estão sendo usadas, no artigo, com o intuito de não se definir quais são, de fato, os direitos dos socioeducandos, pois podem ter um efeito retórico de restringir ou ampliar, de uma forma vaga, os direitos fundamentais dos adolescentes privados de liberdade.

Do ponto de vista da dimensão temporal, o artigo 124 do ECA, que elenca os direitos dos adolescentes em conflito com a lei, contradiz o art. $2^{\circ}$, acima, do Regimento Interno das Unidades de Internação do DF da seguinte forma:

(54) Art. 124. São [Processo relacional identificativo] direitos do adolescente privado de liberdade [Identificado], entre outros, os seguintes [Identificador]:

\footnotetext{
${ }^{26}$ Neves (2013, p. 68-69) argumenta que nenhuma forma verbal pode definir-se de maneira isolada ou descontextualizada. Permanecendo ainda nos domínios definidos pelas relações estruturais, ou sintáticas, temse de conjugar o complexo funcional de estatuto mórfico - a forma verbal - ao seu contexto sintático. Sendo assim, a investigação da significação das formas verbais devem ser investigadas também na sua função de conjugação modo-temporal do enunciado. Portanto, qualquer forma verbal constitui a manifestação de um complexo categórico-lexical que é o responsável pela ancoragem do texto, pois só o verbo tem tempo nas coordenadas da enunciação.
} 
I - entrevistar-se pessoalmente com o representante do Ministério Público;

II - peticionar diretamente a qualquer autoridade;

III - avistar-se reservadamente com seu defensor;

$I V$ - ser informado de sua situação processual, sempre que solicitada;

$V$ - ser tratado com respeito e dignidade;

VI - permanecer internado na mesma localidade ou naquela mais próxima ao domicílio de seus pais ou responsável;

VII - receber visitas, ao menos semanalmente;

VIII - corresponder-se com seus familiares e amigos;

$I X$ - ter acesso aos objetos necessários à higiene e asseio pessoal;

$X$ - habitar alojamento em condições adequadas de higiene e salubridade;

$X I$ - receber escolarização e profissionalização;

XII - realizar atividades culturais, esportivas e de lazer;

XIII - ter acesso aos meios de comunicação social;

$X I V$ - receber assistência religiosa, segundo a sua crença, e desde que assim o deseje;

$X V$ - manter a posse de seus objetos pessoais e dispor de local seguro para guardá-los, recebendo comprovante daqueles porventura depositados em poder da entidade;

XVI - receber, quando de sua desinternação, os documentos pessoais indispensáveis à vida em sociedade.

$\S 1^{\circ}$. Em nenhum caso haverá incomunicabilidade.

$\S 2^{\circ}$. A autoridade judiciária poderá suspender temporariamente a visita, inclusive de pais ou responsável, se existirem motivos sérios e fundados de sua prejudicialidade aos interesses do adolescente.

(ECA, Livro II, Parte Especial, Título III - Da Prática de Ato Infracional, Capítulo IV - Das Medidas Socioeducativas, Seção VII -

Da Internação)

No excerto (54), faço uso de dois Dispositivos de lei para a análise textual: o rol taxativo ou numerus clausus, expressão que, conforme Rónai (1984, p. 123), equivale "a número fechado" e implica acesso limitado, pois o legislador ou juiz podem, tacitamente, limitar a interpretação da lei e o rol exemplificativo ou numerus apertus, expressão antônima à anterior, equivalente a número ilimitado, na medida em que há uma extensão de sentidos, pois o legislador escolhe alguns exemplos do que está sendo protegido na lei e deixa a critério do leitor complementar a sentença com opções análogas.

Sendo assim, considera-se taxativa a construção textual referente aos direitos socioeducando devido à força semântico-modo-temporal do processo relacional identificativo ser, em são, e o identificador seguintes. Observe-se que o identificador, nesse caso, determina a enumeração das garantias do adolescente nas Unidades de Internação, como ter acesso aos objetos necessários à higiene e asseio pessoal, habitar alojamento em condições adequadas de higiene e salubridade; receber escolarização e profissionalização; realizar atividades culturais, esportivas e de lazer; ter acesso aos meios de comunicação social; receber assistência religiosa, segundo a sua crença, se o desejar; receber, quando desinternado, os documentos 
pessoais indispensáveis à vida em sociedade; não ser mantido em incomunicabilidade e por fim, ser tratado com respeito e dignidade.

Contudo, a expressão entre outros, em são direitos do adolescente privado de liberdade, entre outros, os seguintes, no excerto (54), permite apontar o mesmo processo de redação do fragmento (53), em visando favorecer o acesso aos direitos fundamentais, tais como, saúde, educação, profissionalização, trabalho, assistência social, esporte, cultura e lazer, dentre outros, com o uso do item exemplificativo. Esses casos permitem uma análise e interpretação subjetivas e uma dedução do que poderá ou deverá ser cumprido no que se refere à lei, o que envolve, nesses casos, o cruzamento de dois eixos: o eixo da possibilidade e o eixo da obrigatoriedade.

Já o artigo 125, no fragmento (55), aborda a questão da integridade do socioeducando e mostra que a responsabilidade pelo zelo da integridade é do Poder Público, como pode ser apreciado no seguimento abaixo:

(55) Art. 125. É [Oração relacional identificativa] dever do Estado [Valor] zelar pela integridade física e mental dos internos [Característica], cabendo-lhe adotar as medidas adequadas de contenção e segurança.

(ECA, Livro II, Parte Especial, Título III - Da Prática de Ato Infracional, Capítulo IV - Das Medidas Socioeducativas, Seção VII -

Da Internação)

(55a) É dever do Estado zelar pela integridade física e mental dos internos,

(55b) cabendo-lhe adotar as medidas adequadas de contenção e segurança.

No excerto (55), evidencia-se que o Estado realiza o papel específico de protetor. ${ }^{27}$ Nessa vertente, é possível definir a direção do processo de identificação (THOMPSON, 2004), que, nesse caso, vai do geral para o específico, visto que é dever do Estado cuidar da integridade física e mental dos socioeducandos. Note-se que há um comando o qual determina o dever do Estado. Em (55a), a primeira parte do artigo, no fragmento é dever do Estado zelar pela integridade física e mental dos internos, observa-se um comando taxativo, com a utilização do processo relacional identificativo ser, em ée, pois os deveres se resumem nas duas modalidades de integridade: a física e a mental dos internos, uma vez que não existem outras opções de deveres, no enunciado, a serem cumpridos.

\footnotetext{
${ }^{27}$ Conforme sugerem Halliday e Matthiessen (2004, p. 234-235), há significados que podem caracterizar tipos de identificação, dentre os quais se encontram os de equivalência/igualdade, de nomeação, definição, simbolização, realização de papéis.
} 
Entretanto, na segunda parte do artigo, (55b), no fragmento cabendo-lhe adotar as medidas adequadas de contenção e segurança, observa-se que, quando são citadas as medidas adequadas de contenção e segurança, sem que se definam quais são elas, abre-se a possibilidade de o executor da norma adotá-las de acordo com o que ele acredita serem tais medidas, conforme sua visão de mundo, crenças, atitudes e valores. Isso evoca o pensamento de Barros (2015, p. 61-62) ao argumentar que se pode construir textualmente o mundo social de modos particulares, entretanto a representação dependerá de vários fatores contextuais.

Dessa forma, percebe-se que, nos artigos 124 e 125, nos excertos (54) e (55), o processo ser, nas formas são e é, em tempo presente, enfoca os direitos do adolescente interno e reconhecimento da responsabilidade do Poder Público, respectivamente. Vejamos, a seguir, dentro da mesma cadeia genérica discursiva, o documento que projeta medidas aplicáveis, tais como princípios e finalidades, que zelam pela integridade do jovem em termos de formação e cidadania. Trata-se, nesse caso, de fundamentos pertinentes aos Colégios Militares.

(56) Art. $3^{\circ}$ Além da finalidade prevista no Regulamento dos Colégios Militares (R-69), cabe aos CM [Ator], por meio da sua ação educacional [circunstância de modo], prover [processo material] ao corpo discente [beneficiário recebedor] o desenvolvimento integral, a formação para o exercício da cidadania e os meios para progredir nos estudos posteriores e no exercício de sua atividade profissional [Meta].

(Regimento Interno dos Colégios Militares, Título I, Do Estabelecimento de Ensino, Dos Princípios e Das Finalidades, Capítulo II Dos Princípios, Das Finalidades e Dos Fundamentos, 2011, p.1)

(57) Art. $1^{o}$ Este Regulamento tem por finalidade estabelecer preceitos comuns aplicáveis aos Colégios Militares.

(Regulamento dos Colégios Militares (R-69), 2008, p.3)

Os excertos (56) e (57) envolvem princípios que culminam em finalidades próprias de regimentos militares, o que evoca uma "intertextualidade explícita" ${ }^{28}$, segundo Koch, Bentes e Cavalcante (2012, p. 28) e, que para Fairclough (FAIRCLOUGH, 2001, p.114), constitui uma "intertextualidade manifesta". Em poucas palavras, cabe aqui registrar que tal intertextualidade é expressa de maneira sintética na referência R69 (Regulamento dos Colégios Militares), em vigência desde 2008.

Apesar de tratar de um mesmo tema, qual seja, finalidade, os dois regimentos, dos Colégios Militares e das Unidades de Internação, em seus excertos (53) $O$ atendimento buscará garantir a proteção integral dos direitos dos socioeducandos, por meio de um

\footnotetext{
${ }^{28}$ Koch, Bentes e Cavalcante (2012) sugerem que a intertextualidade será explícita quando, no próprio texto, é feita menção à fonte do intertexto, ou seja, quando outro texto ou fragmento é citado.
} 
conjunto articulado de ações governamentais e não-governamentais, da União, Estado, Distrito Federal e dos Municípios, visando favorecer o acesso aos direitos fundamentais, tais como, saúde, educação, profissionalização, trabalho, assistência social, esporte, cultura e lazer, dentre outros e (56) Além da finalidade prevista no Regulamento dos Colégios Militares (R-69), cabe aos CM, por meio da sua ação educacional, prover ao corpo discente o desenvolvimento integral, a formação para o exercício da cidadania e os meios para progredir nos estudos posteriores e no exercício de sua atividade profissional apresentam-se de formas diferenciadas.

É possível observar a relação de um enunciado incerto no Regimento Interno das Unidades de Internação referente a um fato que poderá ou não ocorrer e de um enunciado real e concreto no Regimento Interno dos Colégios Militares. Nessa perspectiva, com a comparação feita dos artigos 124 e 125 do ECA, bem como com o $2^{\circ}$ artigo do RIUI, pude evidenciar que a marcação das determinações temporais, futuro e presente, indiciam, respectivamente, a asserção de possibilidade e a asserção de fato, visto que o Regimento Interno das Unidades de Internação do DF trata da possibilidade de os socioeducandos terem acesso aos direitos dentro da Unidade, pois eles podem ou não desfrutar dos direitos. Esses artigos permitem uma análise e interpretação subjetivas e uma dedução do que poderá ou deverá ser cumprido no que se refere à lei, o que permite a observação do cruzamento de dois eixos: o eixo da possibilidade e o eixo da obrigatoriedade. Já o Regimento Interno dos Colégios Militares aponta, de forma taxativa, a preocupação da Instituição em relação ao discente, no momento em que determina os objetivos para o desenvolvimento, formação e progressão do aluno.

\subsubsection{Deveres versus direitos}

Nesta subseção, a análise terá como tema central os direitos e deveres do socioeducando e dos estudantes em seus respectivos regimentos. Dessa forma, as análises buscam identificar os diferentes tipos de significados que são usados e como a linguagem é organizada para criar significados (EGGINS, 2004), de acordo com o contexto, porque, como enfatiza Halliday (1989), o princípio da multifuncionalidade é considerado fundamental para “uma interpretação funcional da linguagem". Sendo assim, "modalidade”, como um recurso linguístico de interpessoalidade, tem o seu destaque no excerto (58), como se pode observar nas análises dos fragmentos abaixo. 
(58) Art. 26 Os(As) socioeducandos(as) [Sujeito] em regime de internação - estrita, provisória ou, excepcionalmente, sanção [Adjunto] - devem atentar para as normas institucionais de conduta, segurança e disciplina, fixadas em Cartilha do(a) Socioeducando(a) ou constantes de regulamentação específica, dentre as quais se destacam [Complemento circunstancial].

I - obrigatoriedade do fornecimento de informações necessárias ao processo socioeducativo atinentes aos seus familiares, cônjuge ou pessoas com as quais mantenha vínculo afetivo, conforme avaliação especializada da equipe interdisciplinar da GESP $e$ GESP Feminina; à saúde; ao endereço e à formação escolar e profissional, quando houver, que devem constar de prontuário individual;

II - uso estrito dos trajes definidos como adequados em Cartilha do(a) Socioeducando(a); III - manutenção de higiene pessoal e limpeza dos ambientes que habitar ou transitar, conforme manual de procedimentos da GESEG e GESEG Feminina normativas institucionais atinentes a esta demanda;

$I V$ - conservação da habitabilidade, salubridade e integridade das instalações físicas da unidade, de acordo com manual de procedimentos da GEAD, da GESEG e da GESEG Feminina e normativas institucionais atinentes a esta demanda;

$V$ - participação com frequência e interesse nas atividades socioeducativas obrigatórias, sob pena de cumprimento sanção disciplinar, conforme Regime Disciplinar, bem como nas facultativas a que se comprometer, observadas as normativas vigentes e instruções fornecidas pelos gestores intergerenciais da Escola, do NUASE, da GESP e GESP Feminina e da GESEG e GESEG Feminina;

$V I$ - tratamento com respeito e dignidade para com os(as) demais socioeducandos(as);

VII - tratamento com respeito, dignidade e subordinação dos(as) servidores(as) e funcionários(as) da unidade, conforme disposto em Cartilha do(a) Socioeducando(a);

VIII - organização de seus pertences pessoais e cuidado com todo material que lhe for fornecido, inclusive escolar, conforme disposto em Cartilha do(a) Socioeducando(a) $e$ normativas escolares vigentes;

IX - obediência das prescrições e orientações médicas, psicológicas, odontológicas e farmacêuticas, conforme orientações da GESAU elou da equipe interdisciplinar da GESP e GESGP Feminina, sob supervisão destas e em acompanhamento e supervisão da GESAU;

$X$-atendimento das determinações de sua equipe interdisciplinar de referência;

$X I$ - manutenção de diálogo habitual e honesto com os profissionais da equipe interdisciplinar de referência, sob supervisão da Chefia elou Gerência, tratando acerca de suas demandas, com a obrigatoriedade de informar acerca de situações de ameaça a sua integridade física e psicológica, em referência às normativas institucionais, inclusive as da GESEG e GESEG Feminina;

XII - consumo de alimentos sem desperdício e com higiene;

XIII - submissão às medidas e determinações judiciais e da equipe interdisciplinar de referência, sob supervisão gerencial e da Direção, com observância da Cartilha do(a) Socioeducando.

(Regimento Interno da Unidade de Internação de Santa Maria - DF, 2014, p.35)

Nota-se, no excerto (58), a modalidade deôntica, realizada por meio do verbo dever, na categoria no eixo da obrigatoriedade, uma vez que há uma proposta de comando no grau de obrigação realizada gramaticalmente pelo elemento verbal. O art. 26 do RIUI determina que os socioeducandos devem prestar atenção para as normas institucionais de conduta e segurança, fixadas em Cartilha do Socioeducando ou constantes de regulamentação específica. 
Entretanto, a modalidade deôntica torna-se vazia de significado para os socioeducandos da UISM, pois não existe, na Unidade de Internação, a referida cartilha. A propósito, necessário se faz observar que o trabalho de análise pode estar ligado a fatores, dentre os quais a cultura, os valores e a contextualização trazidos pelo linguista, o que obriga o analista a conhecer o contexto no qual o fragmento foi produzido. Faço essa ressalva, pois, como pesquisadora, constatei que não existe a Cartilha do Socioeducando na Unidade de Internação. Registre-se, então, que a referência do socioeducando é proforma, uma vez que tal documento não foi criado. Sendo assim, a modalidade deôntica, no excerto (58), torna-se inexistente para o Sujeito, porquanto, no Complemento e nas circunstâncias, há mensagens inconsistentes e incoerentes. Nessa perspectiva, a obrigatoriedade expressa para que o adolescente em situação de reclusão deva atentar para as normas institucionais de conduta, segurança e disciplina, fixadas em Cartilha do(a) Socioeducando(a) torna-se inócua, na medida em que não existe, na UISM, a referida cartilha.

No excerto (59), far-se-á uma análise do artigo referente aos deveres e direitos dos alunos do Colégio Militar. Apreciemos.

(59) Art. 103. Os deveres e direitos dos alunos [Identificado], além dos constantes no R-126, em seus artigos 45 e 46 e em normas que regulam situações específicas [Circunstância de localização], são [Processo Relacional identificativo] os preconizados [Identificador] nos diversos títulos do presente RI [Circunstância de localização], complementados pelo que especifica este artigo.

(Regimento Interno dos Colégios Militares, Título IX Do Corpo Discente, Capítulo III Dos Deveres e Direitos dos Alunos, 2011, p.37)

No excerto (59), são apontados, em diversos documentos, os direitos e os deveres dos alunos. As circunstâncias de localização estão representadas por no R-126, por em normas específicas reguladoras de situações específicas, bem como por nos diversos títulos nos Regimentos Internos apontam onde os direitos e deveres dos alunos. Essas circunstâncias de localização podem ser remetidas à intertextualidade manifesta proposta por Fairclough (2001, p.114), para quem "a intertextualidade diz respeito à propriedade que têm os textos de serem cheios de fragmentos de outros textos”. Resulta que, ao se definir onde estão os direitos e deveres, instaura-se uma diretriz que guia o leitor para estar a par de quais são os direitos e deveres dos alunos.

Ambos os excertos tratam de deveres dos adolescentes, entretanto, no artigo 26, no excerto (58), do Regimento Interno da Unidade de Internação de Santa Maria, nota-se a 
informação incompleta devido à falta de clareza e inconsistência nas relações léxicogramaticais.

\subsubsection{As Medidas Disciplinares}

Nesta subseção, será analisado, nos fragmentos (60) e (61), o tema "medidas disciplinares", enquanto ações praticadas pelas Unidades de Internação e pelos Colégios Militares. Cabe destacar que, em ambos os excertos, há o Processo Relacional atributivo contribuindo para que se defina e estruture o conceito do tema abordado, como se pode observar abaixo.

(60) Art. 80: Medida disciplinar [Portador] diz respeito a [processo relacional atributivo] uma sanção aplicada [Atributo] ao adolescente que comete alguma prática considerada transgressora às regras da Unidade, devendo ser aplicada [processo material abstrato] de acordo com avaliação da Equipe de Referência, a Gerência Socioeducativa e a Gerência de Segurança [circunstância de modo].

(Regimento Interno das Unidades de Internação do DF, Capítulo III Do Regulamento Disciplinar, Seção I - Das Disposições Gerais, p.28, 2013)

No excerto (60), que faz parte do Regimento Interno das UI do Distrito Federal, o Portador, qual seja, a medida disciplinar, está diretamente relacionado ao ato de sanção. A sanção aplicada parece representar o Atributo que busca coibir ou prevenir a ação do adolescente em situação de reclusão. Podem ser destacadas, nesse fragmento, as escolhas lexicais, bem como expressões, encharcadas de tessitura semântica, que remetem à prática de infração. Dá-se importância a expressões que evidenciam a conduta infracional do adolescente, tais como: comete, sanção, transgressora às regras. A questão da agência é levantada como uma ação de coerção com a nominalização de sanção, o que denota um aspecto socialmente significante voltado para a imposição de poder.

No campo lexical, há uma mudança de papéis da unidade vocabular adolescente, pois, em termos de sanção, exerce o papel de afetado. Como transgressor, o adolescente pode ser considerado, nos termos de Fairclough (2003), como "agente social", porque pode ser visto, inclusive, como representante de um grupo. Cabe ressaltar que esse agente social é uma entidade participante do processo. Entretanto, quando a efetiva ação de punição lhe for aplicada, será ele o afetado. A circunstância específica para a aplicação da sanção envolve a avaliação das denominadas Equipe de Referência, a Gerência Socioeducativa e a Gerência de Segurança, que são instâncias autorizadas na instituição da Unidade de Internação (UI). 
(61) A medida disciplinar [Portador] é [processo relacional atributivo] um instrumento de caráter educativo [Atributo] para a preservação da disciplina escolar, elemento indispensável à formação integral do aluno [circunstância de finalidade].

(Guia do Aluno e do Responsável, 2014, p. 26)

No excerto (61), do Guia do Aluno e do Responsável, concernente ao Regime Disciplinar do CMB, a característica evidente e atributo do Portador é o caráter educativo disciplinar. Essa relação abstrata ressalta a importância dada à disciplina no referido fragmento que vem como fator preponderante à formação do aluno. As nominalizações preservação e formação indiciam as representações dos efeitos sociais, pontos positivos para crescimento e relações sociais do aluno. A circunstância evidencia a finalidade do instrumento socioeducativo utilizado na instituição.

O que mais cabe ressaltar é o fato de que os termos selecionados em ambos os excertos fazem parte do mesmo campo lexical. Entretanto, eles divergem na tessitura semântica no contexto em que são registrados. No excerto (60), há uma conotação de medida disciplinar como um ato negativo, coercitivo, voltado para aqueles que transgredirem normas e regras. Os rótulos da “cultura negativa” (FAIRCLOUGH, 2003, p. 23) tornam-se visíveis, a partir do momento em que são feitas escolhas lexicais, tais como comete, sanção, transgressora. Parece não existir a preocupação socioeducativa com os socioeducandos. $\mathrm{O}$ discurso é aplicado em forma de punição e de correção de um ato cometido, não de reeducação. Já no excerto (62), existe um objetivo de mostrar a relação de construção e crescimento do aluno para se tornar um cidadão com a disciplina. A expressão medida disciplinar, no documento, é vista como um meio que envolve a educação e o social, bem como a formação integral do aluno.

Assim sendo, é notório que as expressões mais frequentes que marcam a denominada cultura negativa do mundo do crime, para os adolescentes que cometem infrações, demandam um mergulho analítico mais profundo na interdiscursividade observada nas convenções discursivas dos documentos ora comparados.

\subsubsection{As faltas disciplinares}

Nesta subseção, discuto dois excertos pertinentes à falta disciplinar, mediante ações praticadas pelos adolescentes, seja das Unidades de Internação de Santa Maria, seja do Colégio Militar de Brasília. Observe-se que, embora haja diferença de foco nos dois documentos, há uma convergência no tema. Vejamos. 
(62) Art. 27 Ao(À) socioeducando(a) [beneficiário] em regime de internação - estrita, provisória ou, excepcionalmente, sanção [circunstância de modo] - que incorrer na prática de ato de transgressão às normas institucionais tipificado neste instrumento como falta disciplinar será aplicada [processo material abstrato] medida disciplinar [meta], em conformidade com os procedimentos consignados em normativa específica [circunstância de modo].

(Regimento Interno da Unidade de Internação de Santa Maria, 2014, p.37)

No excerto (62), há uma determinação da aplicabilidade da medida disciplinar (Meta), ou seja, a quem se dirige a ação. O socioeducando é o beneficiário do processo material, em uma relação assimétrica de poder, pois é ele o alvo da meta. Dessa forma, o agenciamento do poder se dá por meio de uma tríade: meta-processo-beneficiário, o que acarreta um comando, em termos de aplicabilidade, o de ser aplicado. Trata-se de sanção a ser executada em uma circunstância de modo específica, ou seja, na prática de ato de transgressão às normas.

(63) Falta disciplinar [Portador] é [processo relacional atributivo] qualquer violação dos preceitos de ética, dos deveres e obrigações escolares, das regras de convivência social e dos padrões de comportamento impostos aos alunos [Atributo], em função do sistema de ensino peculiar aos Colégios Militares [circunstância de modo].

(Guia do Aluno e do Responsável, 2014, p. 25)

Já no excerto (63), identifica-se uma unidade de informação configurada em oração relacional intensiva, pois há a caracterização de uma entidade, qual seja, a falta disciplinar. O Atributo tem como núcleo violação.

Observe-se que a nominalização expressiva, nos excertos (62) e (63), nos itens lexicais violação e transgressão, propicia uma semelhança entre os artigos, pois se encontram no mesmo campo semântico. Violação e transgressão referem-se a um comportamento inadequado, tanto do socioeducando da Unidade de Internação quanto do aluno do CMB. Já a circunstância de modo evidencia uma característica de como os jovens devem se adequar ao sistema imposto. Ademais, é um caráter significativo das formas simbólicas do modo de Nominalização sugerido por Thompson (2011, p. 80), em que às ações é atribuído o sentido de um nome.

Os dados analisados nessa subseção mostraram a necessidade de buscar a interioridade da gramática para trazer luz ao que faz da língua um contrato social. Os dados foram discutidos com o propósito de descrever e interpretar as práticas sociais configuradas em práticas discursivas registradas em dois regimentos internos. Como alvo das medidas 
disciplinares apontam para cultura negativa do mundo da vida, busca-se estender um olhar mais atento para as práticas sociais do vigiar e punir, tema enfocado a seguir.

\subsection{O PODER DE VIGIAR E PUNIR}

De acordo com o grau da falta disciplinar do aluno do CMB ou da transgressão do socioeducando da Unidade de Internação, há medidas disciplinares específicas aplicáveis. Essas medidas, na concepção de Foucault (2004), são chamadas de instrumentos simples. Nota-se, portanto, uma relação intrincada entre discurso e poder, haja vista as medidas aplicáveis aos adolescentes estarem inseridas nos discursos disciplinadores. Enfatiza Foucault (2003, p. 252) que "o poder não é nem fonte nem origem do discurso. O poder é alguma coisa que opera através do discurso, já que o próprio discurso é um elemento em um dispositivo estratégico de relações de poder".

Ressalte-se que as medidas disciplinares analisadas acima revestem-se de dupla função: por um lado, possuem um propósito punitivo, pois são constituídas maneiras de responsabilização por um ato (infracional) cometido; por outro, há um teor vigilância educativa, na medida em que devem proporcionar ao adolescente a compreensão da gravidade do ato que ele cometeu e de suas consequências.

A seguir, será feita, pela lente da exterioridade, uma comparação, com base no pensamento de Foucault (2004), dos instrumentos simples utilizados nas UI e no CMB, a partir dos excertos dos Regimentos Internos das respectivas Instituições.

(64) Artigo 89 - No caso de transgressões disciplinares que caracterizarem ato infracional ou, no caso de maiores, crime, a autoridade competente deverá ser acionada.

Artigo 90 - São tipos de medidas disciplinares aplicáveis:

I. Advertência: admoestação verbal, aplicável às infrações de natureza leve, utilizando-se de técnicas de mediação de conflito;

II. Advertência Escrita: admoestação verbal revestida de maior rigor e reduzida a termo, aplicável em casos de infração de natureza média, bem como na hipótese de reincidência em infrações de natureza leve;

III. Suspensão: o socioeducando é suspenso da participação de atividades recreativas, festejos, passeios e outras atividades não obrigatórias. Aplicável nos casos de ocorrência de infrações de natureza média, grave elou gravíssima.

$\S 3^{\circ}$ - A aplicação da restrição parcial ou total de saída externa será a cargo da comissão de avaliação, apurando-se cada caso, bem como suas reincidências.

Parágrafo único: Os Relatos das ocorrências disciplinares poderão ser enviados ao Poder Judiciário e ao Ministério Público, com requerimento inclusive para outras providências cabiveis. 
(Regimento Interno das Unidades de Internação do DF, Capítulo VII Do Regulamento Disciplinar, Seção III - Das Medidas Aplicáveis, 2013, p.32 - 33)

(65) Falta disciplinar é qualquer violação dos preceitos de ética, dos deveres e obrigações escolares, das regras de convivência social e dos padrões de comportamento impostos aos alunos, em função do sistema de ensino peculiar aos Colégios Militares;

b) As medidas disciplinares a que estão sujeitos os alunos são as seguintes, em ordem de gravidade crescente:

1) Advertência;

2) Repreensão;

3) Atividade de orientação educacional (AOE);

4) Retirada do Colégio, que poderá ser substituída por atividade de estudo aos sábados elou domingos, das 09 h00 às $11 \mathrm{~h} 30$;

5) Desligamento.

(Guia do Aluno e do Responsável, 2014, p. 26)

O ponto de partida dessa análise é a observação das medidas disciplinares, configuradas tanto nas medidas disciplinares, quanto nas faltas aplicáveis, pois elas representam uma forma de poder nas Instituições. Dessarte, é relevante vir à tona a ideia de Foucault (2004, p. 143-163) a respeito de poder, porque, para ele, o êxito do poder disciplinar se deve ao uso de instrumentos simples, como: a vigilância hierárquica (pode-se observar e enxergar tudo e todos, instituindo-se uma rede), a sanção normalizadora (na qual quaisquer desvios do indivíduo são passíveis de penalização, por meio de correção ou punição) e o exame (o indivíduo é visto como efeito e objeto de poder e de saber).

Nesse sentido, os discursos disciplinadores das duas instituições em tela inserem-se na assertiva do autor (FOUCAULT, 2004, p. 143-163), para quem "o sucesso do poder disciplinar se deve, sem dúvida, ao uso de instrumentos simples: o olhar hierárquico, a sanção normalizadora e sua combinação num procedimento que lhe é específico, o exame". No Quadro 4.5, abaixo, será feito um comparativo desses instrumentos utilizados pelas instituições em estudo, os Colégios Militares (doravante CM) e as Unidades de Internação (UI) quais sejam: a vigilância hierárquica, a sanção normalizadora e o exame. 


\section{Quadro 4.5 - Diferenças e semelhanças dos instrumentos disciplinares indicados por Foucault nos Colégios Militares e nas Unidades de Internação}

\begin{tabular}{|c|c|c|}
\hline Instrumentos & Colégios Militares & Unidades de Internação \\
\hline $\begin{array}{l}\text { Vigilância } \\
\text { hierárquica }\end{array}$ & $\begin{array}{l}\text { Professores, pedagogos, } \\
\text { psicólogos- militares- } \\
\text { Comandante do Colégio- } \\
\text { câmeras de segurança }\end{array}$ & $\begin{array}{l}\text { Professores, pedagogos, psicólogos - militares\policiais- } \\
\text { Diretor(a) da Instituição- câmeras de segurança }\end{array}$ \\
\hline $\begin{array}{l}\text { Sanção } \\
\text { normalizadora }\end{array}$ & $\begin{array}{l}\text { Advertência } \\
\text { repreensão- atividade de } \\
\text { estudo de caráter } \\
\text { disciplinar e educativo } \\
\text { atividade de orientação } \\
\text { educacional } \\
\text { retirada do colégio } \\
\text { desligamento disciplinar }\end{array}$ & $\begin{array}{l}\text { advertência (admoestação verbal, aplicável às infrações } \\
\text { de natureza leve, utilizando-se técnicas de mediação de } \\
\text { conflitos) - advertência escrita (admoestação verbal } \\
\text { revestida de maior rigor e reduzida a termo, aplicável } \\
\text { em casos de infração de natureza média, bem como na } \\
\text { hipótese de reincidência de infrações de natureza leve) - } \\
\text { suspensão (o socioeducando sofre admoestação verbal } \\
\text { reduzida a termo e é suspenso da participação de } \\
\text { atividades recreativas, festejos, passeios e outras } \\
\text { atividades não obrigatórias. Fica em módulo separado. } \\
\text { Aplicável nos casos de ocorrência de infrações de } \\
\text { natureza média elou gravíssima). }\end{array}$ \\
\hline Exame & 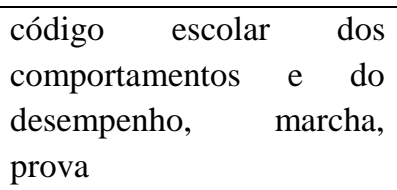 & código de comportamento e desempenho \\
\hline
\end{tabular}

Fonte: elaborado pela autora

O Quadro 4.5 permite-nos destacar que ambas as instituições têm a mesma estrutura, no que tange à vigilância hierárquica. Já na sanção normalizadora podem ser observadas as diferentes aplicabilidades das medidas disciplinares, por serem contextos diversos, visto que nas Unidades de Internação os socioeducandos estão em situação de reclusão. Entretanto, isso nos remete à ideia de que

na essência de todos os sistemas disciplinares, funciona um pequeno mecanismo penal. É beneficiado por uma espécie de privilégio de justiça, com suas leis próprias, seus delitos especificados, suas formas particulares de sanção, suas instâncias de julgamento. As disciplinas estabelecem uma 'infra-penalidade'; quadriculam um espaço vazio pelas leis; qualificam e reprimem um conjunto de comportamentos que escapava aos grandes sistemas de castigo por sua relativa indiferença. (FOUCAULT, 2004, p. 149)

Dessa maneira, são penalizáveis as frações mais tênues de uma conduta irregular às mais graves. Ou seja, todos os desvios, tudo que está inadequado às regras e tudo que se 
afasta delas é passível de punição. Por último, há o exame que é a combinação das técnicas de hierarquia, a qual vigia, e da sanção, que normaliza, pois é uma vigilância e um controle normalizante que podem qualificar, classificar, punir, estabelecendo sobre os indivíduos uma visibilidade por meio da qual eles são diferenciados e sancionados. Nele, reúnem-se a cerimônia do poder e a forma da experiência, a demonstração da força e o estabelecimento da verdade. São exemplos do exame, no $\mathrm{CM}$, o código escolar dos comportamentos e do desempenho, a observação, a marcha, a prova, o conselho de classe e, na UI, o código de comportamento e desempenho, a observação, a audiência com o(a) juiz(a).

Isso posto, é possível notar que, embora com características próprias e peculiares, devido à especificidade de situações e contextos, nas duas instituições são aplicados instrumentos disciplinares com a função de hierarquia, de disciplina, de boa conduta. Observa-se que o discurso disciplinador, em ambas as instituições, tem como pilares o respeito e a obediência. No Colégio Militar, além desses, a hierarquia é extremamente valorizada. Já nas Unidades de Internação, para que se chegue ao objetivo esperado, de obediência e boa conduta, em alguns casos, a coerção e a força física são meios utilizados para disciplinar o socioeducando. Alinhado à discussão de Foucault, serão apresentados fragmentos de relatos dos socioeducandos referentes à forma de poder e à punição dentro da UISM.

(66) "Tem agente que eles já... Levantou a voiz! Já vi internas apanhano aqui dentro. Entendeu? Gosta de batê! ? As menina mesmo, a gente... Ap... Apanho se fizer bagunça! Então... Esse é o lado negativo, porque quanto mais eles bate, mais a gente sai, fica mais revoltado. E eles num entende isso! A diferença é que tem agente que são mais educados com a gente, que a gente respeita pra caramba, num faz bagunça porque a gente tem consideração, mas aqueles agente que a gente vê que é ignorante, a gente fala numa boa, eles vêm com ignorância a gente já... toca o "foda-se"! Porque, não tem o respeito! Pode ter o medo, mas não tem o respeito! Isso é o negativo que tenho. Nem todos agentes aqui, tão aqui pra... Educar! Eles acha que educando é batendo, entendeu?"

(UISM, relato de Felicidade, 2014)

(67) "Experiência negativa que tem é que... Até que é tranq... Um pouco tranquilo, né?, mas uns cara apronta, nóis paga pelo erro que os cara fez, até mesmo nóis tai ficou um tempão de castigo aí por caso que os ôtro fez as coisa que tacô fogo aí! Tentô fugi. Fica de castigo por causo dos otros, os agente num respeita, qualque coisa, nós apanhô aí, por caso, por caso dos otro, os acuia dos agente aí, ó. Aí, eles também num respeita, tem uns que é bom, tem uns que é gente boa, respeita, ajuda! Mas tem ôtos que não!"

(UISM, relato de Elias, 2015) 
(68) (Pesquisadora) - E qual é o tratamento que você recebe aqui? (Abraão) - Ah! Qualqué coisa é... Pancada! Tem tudo isso tamém.

(Pesquisadora) - E você obedece a essas regras?

(Abraão) - Obedeço. Quase toda, mar tem umas que num dá pra obedecê não.

(Pesquisadora) Quais, por exemplo, não dá pra obedecer?

(Abraão) - Qui num pode pidi nada, senão eles vai ficá, eles deixa de medida. Aí tipo, eles tá, bota numa regra que num dá pa obedecê.

(Pesquisadora) - Hum rum. Pedir o quê?

(Abraão) - Pidi alguma coisa pos agente, eles num, eles fica chateado, fica bravo. Aí tipo, qué que nóis obedece eles, né?, nessas questão aí...

(Pesquisadora)-Mas pedir o quê, especificamente?

(Abraão) - Pidi alguma coisa, pidi uma técnica, chama um chefe de segurança... Os bicho A primeira coisa é ter uma turma de segundo ano, que aqui não tem A primeira coisa é ter uma turma de segundo ano, que aqui não tem fala que num vai. Tem que ficá calado dentro do quarto. Caí eu já num falo, falo que vô ficá calado não! Aí eles deixa eu de medida...

(Pesquisadora) - E essa medida, o que é?

(Abraão) - Treis dia de banho de sol de meia hora.

(Pesquisadora) - Geralmente... O banho de sol...

(Abraão) - É de treis horas.

(UISM, relato de Abraão, 2014)

Com os relatos apresentados nos excertos (66), (67) e (68), pondero que os discursos disciplinadores, muitas vezes, tornam-se recontextualizados, de acordo com as vozes de quem os profere e os executa, nos diversos processos de produção de significado. Essa recontextualização, nesse caso, contribui para distorção de sentido(s), porque está aberto a interpretações diversas (FAIRCLOUGH, 2003). Dessa forma, são feitas escolhas lexicais e praticadas ações, em forma de punição, que nem sempre estão expressas nos discursos, para que se obtenha o efeito esperado. Nessa direção, cabe observar que é preciso educar antes de punir e, se houver a necessidade da punição, que ela seja racional, o que nem sempre ocorre. Punir pode, para algumas pessoas, corresponder à rigidez, mas não deveria ser confundido com uso de medidas físicas e/ou verbais violentas, que apenas suscitam mais violência e revolta.

Por isso, as pessoas que trabalham nas instituições têm grande influência no resultado da (re)educação dos adolescentes, pois são elas que recontextualizam os discursos. Sendo assim, a capacitação do profissional, a técnica por eles utilizada e a comunhão desses profissionais com os princípios adotados na instituição são elementos necessários para que se chegue a resultados satisfatórios. Para a concretização desses resultados, também podem ser apontadas a credibilidade e as ideologias inerentes aos documentos que regem uma determinada instituição. Vejamos, a seguir, como são estabelecidas essas questões no RICM e no RIUI. 


\subsection{MODOS OPERACIONAIS PROPOSTOS POR THOMPSON NOS REGIMENTOS INTERNOS DOS CM E DAS UI}

Os modos operacionais da ideologia propostos por Thompson (2011) podem ser encontrados nos Regimentos Internos do $\mathrm{CMB}$ e das UI. Ressalte-se que não foram encontrados, nos regimentos estudados, todos os modos pelos quais a ideologia pode operar. Faz-se necessário destacar que esses recursos propostos por Thompson (2011, p. 79-89) podem imbricar-se, ou seja, em um determinado artigo, podem ser encontrados diferentes modos operacionais da ideologia.

A Legitimação, como modus operandi da ideologia, envolve um modo de operação que busca tornar legítimas e dignas de apoio as relações de dominação. Dessa forma, esse modo de operação simbólica procura tornar legítimo, ou trazer à legalidade, um determinado fato. A Legitimação ocorre em três modos: a Racionalização, a Universalização e a Narrativização. Os excertos (69) e (70), a seguir, sinalizam o modo de operação da ideologia de Racionalização, o qual aponta para uma cadeia de raciocínio que busca justificar um conjunto de relações.

(69) Art. $1^{\circ}$ - A Unidade de Internação tem por objetivo promover, no Distrito Federal o atendimento ao socioeducando em cumprimento de medida socioeducativa, com eficácia, eficiência e efetividade, de acordo com as leis, normas e recomendações de âmbito nacional e estadual. Este Regimento regula os parâmetros de funcionamento e competências das Unidades de execução da medida socioeducativa de Internação do Distrito Federal, considerando os preceitos da Lei 8.069/90 - Estatuto da Criança e do Socioeducando e demais normativas referentes à infância e juventude no Brasil.

(Regimento Interno das Unidades de Internação do DF, Capítulo I Das Disposições Gerais, Seção I - Do Objetivo e Princípios do Atendimento Socioeducativo, 2013, p.1)

(69a) Art. $1^{o}$ - A Unidade de Internação tem por objetivo promover, no Distrito Federal o atendimento ao socioeducando em cumprimento de medida socioeducativa, com eficácia, eficiência e efetividade, de acordo com as leis, normas e recomendações de âmbito nacional e estadual.

(69b) Este Regimento regula os parâmetros de funcionamento e competências das Unidades de execução da medida socioeducativa de Internação do Distrito Federal, considerando os preceitos da Lei 8.069/90 - Estatuto da Criança e do Socioeducando e demais normativas referentes à infância e juventude no Brasil.

(55) Art. $3^{\circ}$ Além da finalidade prevista no Regulamento dos Colégios Militares (R-69), cabe aos CM, por meio da sua ação educacional, prover ao corpo discente o desenvolvimento integral, a formação para o exercício da cidadania e os meios para progredir nos estudos posteriores e no exercício de sua atividade profissional. 
(Regimento Interno dos Colégios Militares, Título I Do Estabelecimento de Ensino, Dos princípios e Das Finalidades, Capítulo II Dos Princípios, Das Finalidades e Dos Fundamentos, 2011, p. 1)

No fragmento (69a), pode ser encontrado o modo padronização, pois as formas simbólicas representadas pela eficácia, eficiência, efetividade parecem estar adaptadas a determinados padrões, que são reconhecidos, partilhados e aceitos por todos. Já no excerto (69b), no segmento oracional Este Regimento regula, ocorre a Legitimação, devido ao verbo regular que evidencia legitimidade. Na sequência, consta, no excerto (69b), que se objetiva promover, no Distrito Federal, parâmetros de funcionamento e competências das Unidades de execução da medida socioeducativa de Internação do Distrito Federal de acordo com o Estatuto da Criança e do Socioeducando e demais normativas referentes à infância e juventude no Brasil. Nesse caso, identifica-se a Universalização, pois o interesse no DF é apresentado como o interesse nacional. Porém, cabe ressaltar, que a Dissimulação torna-se evidenciada, pois há uma transferência de sentidos, na medida em que a realidade destoa do que ocorre efetivamente.

No fragmento (55), já citado anteriormente, é encontrada a padronização, pois há uma justificativa de relações que objetivam adquirir apoio e persuasão ao buscar o desenvolvimento integral, a formação para o exercício da cidadania e os meios para progredir nos estudos posteriores e no exercício de sua atividade profissional.

Além desse modo, também aparece, nos Regimentos Internos, a Unificação, como modus operandi da ideologia. Esse modo consiste em uma construção simbólica de identidade coletiva, que torna os indivíduos "parte de uma unidade da qual não necessariamente fazem parte, mas da qual passam a acreditar que participam" (SILVA F., 2009, p. 224). Divide-se em Estardantização ou Padronização e Simbolização da unidade. Nos excertos (70) e (71), abaixo, pode ser encontrado o modo Estardantização ou Padronização e a Unificação. Vejamos.

(70) Art. $9^{\circ}$ - Aos socioeducandos são assegurados a intervenção mínima, restrita ao necessário para a realização dos objetivos da medida, além de todos os direitos não atingidos pela sentença ou pela Lei, sem distinção de natureza racial, social, religiosa, política, étnica ou relativa à orientação sexual.

(Regimento Interno das Unidades de Internação, Capítulo II Das Disposições Gerais, Dos Direitos, Deveres E Estímulos, Seção I Dos Direitos, Deveres E Estímulos aos Socioeducandos, 2013, p. 7) 
(70a) Art. $9^{\circ}$ - Aos socioeducandos são assegurados a intervenção mínima, restrita ao necessário para a realização dos objetivos da medida, além de todos os direitos não atingidos pela sentença ou pela Lei,

(70b) sem distinção de natureza racial, social, religiosa, política, étnica ou relativa à orientação sexual.

(71) As promoções

a. Batalhão Escolar

A promoção nos diversos graus de hierarquia escolar, constitui recompensa pela aplicação nos estudos, pelo correto procedimento dos alunos, e representa estímulo à formação integral do mesmo e à carreira militar. As graduações e postos da hierarquia escolar vão de cabo-aluno a coronel-aluno.

(CMB, Guia do Aluno e responsável, 2014, p. 30)

(72) Art. $3^{\circ}$ - São princípios do atendimento socioeducativo ao socioeducando:

XXII - não discriminação do socioeducando, notadamente em razão de etnia, gênero, nacionalidade, classe social, orientação religiosa, política ou sexual, associação ou pertencimento a qualquer minoria.

(Regimento Interno das Unidades de Internação do DF, Capítulo I Das Disposições Gerais, Seção I - Do Objetivo e Princípios do Atendimento Socioeducativo, 2013, p.3)

No fragmento (70a), a construção simbólica de identidade coletiva parece estar evidenciada no segmento oracional: Aos socioeducandos são assegurados a intervenção mínima, restrita ao necessário para a realização dos objetivos da medida, além de todos os direitos não atingidos pela sentença ou pela Lei. A Estardantização ocorre, nesse caso, pois há formas simbólicas que são propostas e partilhadas. O fragmento (70b), sem distinção de natureza racial, social, religiosa, política, étnica ou relativa à orientação sexual, sinaliza a Unificação, em uma cadeia de argumentos racionais que justificam as relações, na busca do convencimento de que não existirão diferenças, ou seja, serão todos iguais. Além dessas estratégias, aparece a Dissimulação, pois a determinação normativa quer fazer acreditar que os socioeducandos conviverão sem qualquer diferença, o que parece remeter a um simbolismo utópico.

No fragmento (71), a construção simbólica de identidade coletiva pode ser identificada na recompensa pela aplicação nos estudos, pois nem todos os alunos têm perfil hierárquico e disciplinar, contudo acreditam que podem conseguir tal recompensa. $\mathrm{O}$ processo das graduações e postos da hierarquia escolar que vão de cabo-aluno a coronel-aluno acontece para se manter o status quo da estrutura com a hierarquia militar. O excerto (72) também sinaliza a Unificação no enunciado não discriminação do socioeducando. Entretanto, 
características, que são muitas vezes discriminatórias e preconceituosas, podem levar à intolerância e, consequentemente, a graves conflitos na Unidade de Internação. Isso pode ser evidenciado a fatores como em razão de etnia, gênero, nacionalidade, classe social, orientação religiosa, política ou sexual, associação ou pertencimento a qualquer minoria. Além da Unificação, a Dissimulação também ocorre nesse fragmento, pois os adolescentes, diversas vezes, são chamados de nomes de cunho pejorativo, pelos socioeducadores que compõem o sistema de reeducação do adolescente e pelos próprios socioeducandos, perpetuando-se, assim, as práticas discriminatórias em relação ao grupo de adolescentes.

Outra construção simbólica de identidade coletiva encontrada foi a Fragmentação, a qual envolve a segmentação de grupos ou indivíduos que possam significar ameaça aos grupos detentores do poder. Vejamos.

(73) Art. 47. Está sujeito à exclusão e desligamento o aluno que incorrer em uma das condições previstas no art. 59 e 60 do R-69.

(Regimento Interno dos Colégios Militares, Título V Da Inclusão E Da Exclusão, Capítulo I Do Processo Seletivo e Da Matrícula, 2011, p. 16)

No fragmento (73), pode, também, ser identificada a fragmentação, entretanto, na subcategoria Expurgo do outro, porque os estudantes que não seguem as regras do Colégio Militar são excluídos do sistema. Tanto nas Unidades de Internação, quanto no sistema Colégio Militar, ocorrem punições para os que não aderem ao regimento de forma integral, chegando-se a um grau máximo de ações por parte das instituições: nas Unidades, as formas coercitivas e o isolamento do socioeducando fazem parte dos instrumentos disciplinares aplicados; já nos Colégios Militares, o desligamento ou expulsão do adolescente vêm como últimas instâncias para os estudantes que infringem as normas disciplinares da instituição. Essas ações ocorrem para separar o adolescente "retratado como mau, perigoso, ameaçador" (THOMPSON, 2011, p. 87). Esses alunos são tratados como desafios ou ameaças, diante dos quais a instituição deve se unir para expurgá-lo do convívio da coletividade da instituição.

O que mais cabe ressaltar é o fato de que, nos artigos analisados das Unidades de Internação, mostrou-se presente a Dissimulação. Esse modo, nesses fragmentos, apareceu como forma de disfarçar a realidade do sistema socioeducativo, uma vez que esse sistema parece não apresentar características como eficácia, eficiência, efetividade, haja vista os 
poucos casos de adolescentes reintegrados à sociedade. Ademais, a norma busca apontar uma harmonia e um simbolismo utópicos, pois existem, sim, diferenças de tratamento, tanto por parte dos próprios socioeducandos, quanto por parte dos socioeducadores em relação aos adolescentes em situação de reclusão. Por fim, ainda há práticas discriminatórias flagrantes que "se perpetuam em todos os níveis, atingindo, em especial, os grupos menos favorecidos, entre eles os negros, os indígenas, os imigrantes, as mulheres, os homossexuais" (OLIVEIRA, 2016, p. 189). Dessa forma, o que parece acontecer, no Regimento Interno das Unidades, é um mascaramento da realidade por meio de um discurso dissimulado.

\section{Considerações com base em resultados parciais}

As análises desenvolvidas no Capítulo 4 traçam questões pertinentes às representações dos adolescentes, configuradas linguisticamente, em Documentos Oficiais. Desse modo, foi feito um percurso histórico-linguístico por leis como o Código de Menores de 1927, o Código de Menores, o ECA, a Constituição Federativa do Brasil de 1988 e pelos regimentos dos Colégios Militares e das Unidades de Internação, a fim de apontar a forma como os adolescentes eram e são representados nos documentos.

\section{Quadro 4.6 - Representação dos Adolescentes em Documentos Oficiais}

\begin{tabular}{|c|c|}
\hline Documento & Representação \\
\hline $\begin{array}{l}\text { Código de Menores Mello Matos de } \\
1927\end{array}$ & $\begin{array}{ll}\text { - } & \text { Menor abandonado } \\
\text { - } & \text { Vadio } \\
\text { - Libertino } \\
\text { - } & \text { Mendigo } \\
\end{array}$ \\
\hline Código Penal de 1940 & - Imaturo \\
\hline $\begin{array}{l}\text { Decreto n. } 3.799 \text { que criou o Serviço } \\
\text { de Assistência a Menores }\end{array}$ & $\begin{array}{ll}\text { - } & \text { Menores desvalidos } \\
\text { - } & \text { Menores delinquentes }\end{array}$ \\
\hline Lei 4.513 de $1^{\circ}$ de dezembro de 1964 & - Menor \\
\hline Código de Menores de 1979 & $\begin{array}{l}\text { - } \text { Menor } \\
\text { - } \text { Menor em situação irregular }\end{array}$ \\
\hline Constituição Federal de 1988 & $\begin{array}{l}\text { - Adolescente } \\
\text { - Aluno } \\
\text { - Educando } \\
\text { - Estudante }\end{array}$ \\
\hline
\end{tabular}




\begin{tabular}{|c|c|}
\hline Documento & Representação \\
\hline Estatuto da Criança e do Adolescente & $\begin{array}{l}\text { - Adolescente } \\
\text { - Aluno } \\
\text { - Educando } \\
\text { - Interno }\end{array}$ \\
\hline $\begin{array}{l}\text { Regimento Interno das Unidades de } \\
\text { Internação }\end{array}$ & $\begin{array}{ll}\text { - } & \text { Socioeducando } \\
\text { - } & \text { Adolescente } \\
\text { - } & \text { Aluno } \\
\end{array}$ \\
\hline $\begin{array}{llll}\text { Regimento } & \text { Interno dos } & \text { Colégios } \\
\text { Militares } & & & \end{array}$ & $\begin{array}{ll}\text { - } & \text { Aluno } \\
\text { - } & \text { Discente } \\
\text { - } & \text { Educando } \\
\text { - } & \text { Adolescente }\end{array}$ \\
\hline
\end{tabular}

Fonte: elaborado pela autora

Podemos ilustrar a configuração do percurso representacional do adolescente da seguinte maneira:

Figura 4.6 - Representação de adolescentes como objeto do discurso do Código de Menores de 1927 ao ECA

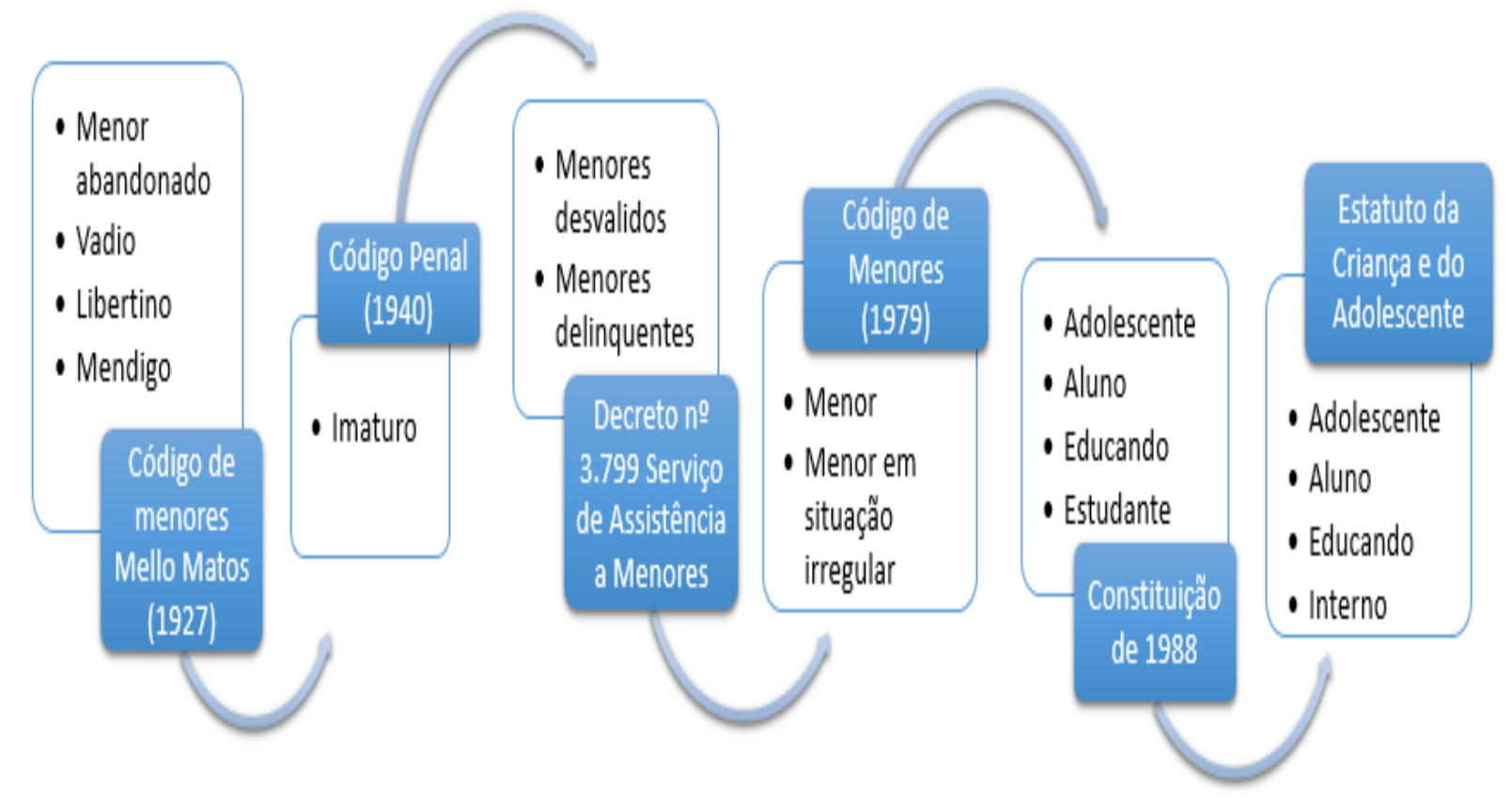

Fonte: elaborado pela autora 
Figura 4.7 - Representação de adolescentes como objeto de discurso no RIUI e no RICM
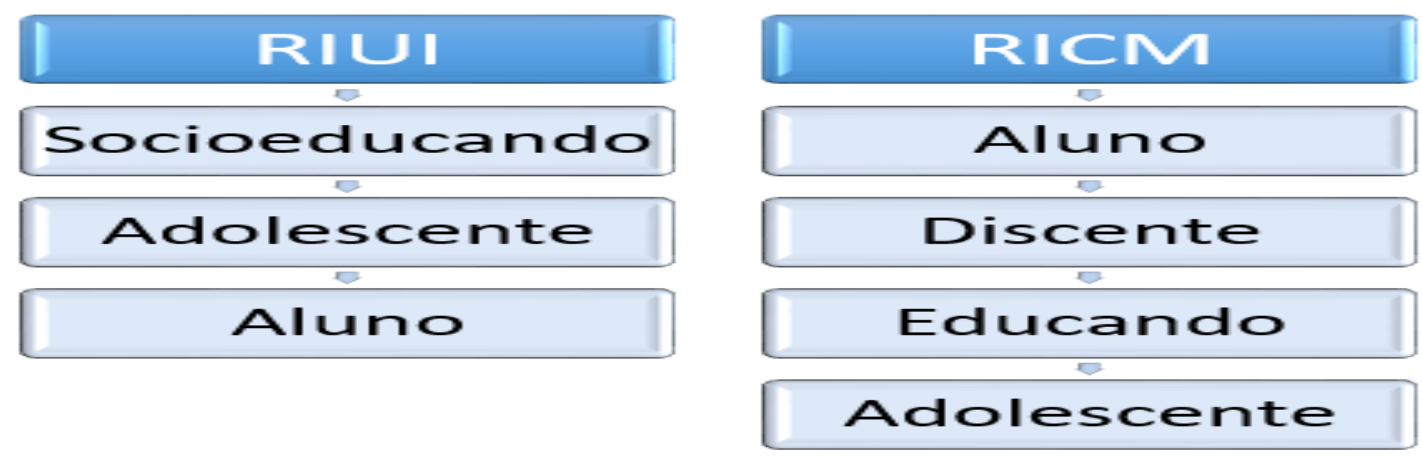

Fonte: elaborado pela autora

Observou-se, no estudo, que houve uma mudança significativa e paradigmática na forma como os adolescentes eram representados e como o são atualmente nos Documentos Oficiais. Antes da Constituição Federal de 1988, os adolescentes, em situação de vulnerabilidade, eram rotulados, de forma discriminatória e pejorativa, por menores, menores abandonados, vadios, delinquentes, libertinos, menores em situação irregular. Hoje, com a nova orientação jurídico-constitucional, a faixa etária de 12 a 18 anos é representada, na maioria dos documentos, por adolescentes, os quais são sujeitos de direitos e deveres, em estado de vulnerabilidade social ou não. Porém, cabe ressaltar que, embora tenham ocorrido modificações na maneira de se referir aos adolescentes, não houve mudanças concretas socioculturais na vida de muitos deles, pois ainda são encontrados muitos em situação de vulnerabilidade social.

Nesse viés documental, fez-se uma análise dos regimentos como gêneros textuais e ação social. A estrutura composicional dos dois regimentos tem divisão diferenciada, visto que o RIUI não aborda temas relativos às atribuições de servidores de modo geral. O que mais cabe salientar é que esse regimento não destaca e nem enfatiza questões relativas à educação, tampouco à profissionalização dentro das Unidades de Internação, temas que deveriam ser primordiais para a reinserção social dos adolescentes.

A análise dos textos teve como instrumento facilitador a ferramenta computacional WordSmith Tools, recurso técnico-científico que propiciou uma descrição mais detalhada de aspectos da composição lexical, bem como da análise da transitividade da Gramática Sistêmico-Funcional proposta por Halliday e Matthiessen (2004). Observou-se que, em ambos 
os regimentos, os processos materiais se sobressaíram. Isso pode ser explicado devido ao gênero textual analisado: Regimento.

Além dos processos materiais, destacaram-se os processos mentais. Uma análise mais detalhada permitiu observar que o RICM torna-se mais humanizado do que o RIUI, já que são escolhidos processos voltados diretamente para benefício do aluno, como aprender, pensar, compreender, conscientizar. Note-se que esse aluno é tratado como ser pensante, dotado de sentimentos e desejos. Já os processos verbais aparecem de forma equilibrada nos dois regimentos, entretanto com cargas semânticas diferenciadas, pois enquanto o regimento dos Colégios Militares registra os processos incentivar, sugerir, informar, esclarecer, estimular, o regimento das Unidades de Internação registra os processos entrevistar, debater, discutir.

Ademais, foram analisados, de forma comparativa, artigos dos dois regimentos que continham temas em comum, tais como princípios do regimento, medidas disciplinares, faltas disciplinares. Notou-se, então, que a marcação das determinações temporais, futuro e presente, indiciaram a asserção de possibilidade e a asserção de fato, visto que o Regimento Interno das Unidades de Internação do DF trata da possibilidade de os socioeducandos terem acesso aos direitos dentro da Unidade, pois eles podem ou não desfrutar dos direitos. Já o Regimento Interno dos Colégios Militares aponta, de forma taxativa, a preocupação da Instituição em relação ao discente, no momento em que determina os objetivos para o desenvolvimento, formação e progressão do aluno.

Contudo, apesar de alguns termos fazerem parte do mesmo campo lexical, eles divergem na tessitura semântica no contexto em que são registrados. Por exemplo, a conotação de "medida disciplinar", no RIUI, está associada a um ato negativo, coercitivo, com um foco nos adolescentes que transgredirem normas e regras. Os rótulos da "cultura negativa" (Fairclough, 2003, p.23) afloram, no momento em que são feitas escolhas lexicais, tais como comete, sanção, transgressora. O discurso é aplicado em forma de punição e de correção de um ato cometido, não de reeducação. Já no RICM, a expressão "medida disciplinar" é vista como um meio que envolve a educação e o social, bem como a "formação integral do aluno". Quanto à nominalização expressiva, nos artigos que tratam de faltas disciplinares, há uma semelhança entre os artigos, em decorrência dos itens lexicais violação e transgressão, pois se encontram no mesmo campo semântico, referindo-se a um comportamento inadequado, tanto do socioeducando da Unidade de Internação quanto do aluno do CMB.

Pôde-se destacar que, tanto nos Colégios Militares quanto nas Unidades de Internação, são aplicados instrumentos disciplinares com a função de hierarquia, de disciplina, de boa 
conduta. Observa-se que o discurso disciplinador, em ambas as instituições, tem como pilares o respeito e a obediência. Entretanto, no Colégio Militar, além desses elementos, a hierarquia é extremamente valorizada. Já nas Unidades de Internação, para que se alcance ao objetivo esperado, de obediência e boa conduta, em alguns casos, a coerção, as palavras proferidas bem como a força física são meios utilizados como formas de tentar disciplinar o socioeducando. Vale ressaltar que o contraste encontrado nos dois regimentos reforça a confirmação de uma hipótese levantada antes de realizar a análise, o que me levou à observação da reincidência de adolescentes às Unidades e, posteriormente, aos presídios. Esse fato me foi atentado devido à minha prática social como professora voluntária na Unidade de Internação, bem como com o estudo feito em presídios no Mestrado.

No que se refere aos alunos dos Colégios Militares, há, implicitamente, nos discursos, o intuito de que os adolescentes representem o país, a começar pelas condutas impostas pelo próprio regimento. Existe uma preocupação em dar uma resposta positiva para a sociedade. Existem princípios de formação de caráter, de educação e de instrução, que podem ser vistos nas escolhas lexicais feitas nos documentos em incentivo ao aprendizado, à capacitação, à disciplina, dentre outros aspectos positivos para o crescimento físico e intelectual do adolescente.

Porém, quando se trata de socioeducandos, parece não haver esse compromisso em dar uma resposta positiva à sociedade, visto que, no próprio regimento, em determinados momentos, não se observa a devida importância àquele que é o foco no documento, qual seja, o socioeducando. Esse fato nos leva a refletir sobre as representações desses jovens: como eles são representados? Como a sociedade os vê? Ou será que não os vê? São esses adolescentes sujeitos inexistentes? E, por serem supostamente inexistentes, são excluídos?

As escolhas lexicais do regimento das Unidades de Internação poderiam ser complementadas sendo o adolescente visto como um sujeito pensante, que necessita de assistência psicológica, pedagógica e física e não somente como mais um delinquente dentro da Unidade. Isso propiciaria o alcance das funções precípuas da internação que são a recuperação e a reintegração social e, por vezes familiar, do socioeducando. Dessa forma, minimizar-se-ia a ideia de que as Unidades de Internação são escolas do crime e meros depósitos de meninos e meninas que sairão dali sem perspectiva de vida e continuarão na vida do crime, tornando-se, reincidentes, nas Unidades e depois nos presídios, como em um ciclo vicioso.

Ressalte-se o fato de que, nos artigos analisados das Unidades de Internação, mostrouse presente a Dissimulação. Esse modo, nesses fragmentos, apareceu como forma de disfarçar 
uma realidade inexistente, um mundo do "faz-de-conta" que não existe, ou existe, somente no regimento.

O próximo capítulo é dedicado à análise e à discussão dos dados empíricos, assim como à continuação da verticalização comparativa entre os dados documentais e as entrevistas. 


\section{CAPÍTULO 5 - A VOZ DOS ADOLESCENTES: UM DUETO EM CONTRASTE}

"Para a pesquisadora da UnB:

Hoje em dia, estou internado na Unidade de Santa Maria

É com muito orgulho que eu me dedico em compor essa poesia para agradecer há todos pela oportunidade,

Por ter abrido minha mente, com muita facilidade

Primeiramente queria agradecer a Deus

Hoje uma pessoa me disse que eu tenho muito potencial

Fiquei muito feliz, não foi como das outras vezes que me

chamaram de marginal

Acho que ela é pesquisadora da UnB

É muito interesante o trabalho dela, gostei de conhecer

Ela falou pra mim que está aqui na Unidade de voluntária

Foi um prazer te conhecer obrigada pelas palavras de motivação

Elas tocou no meu subconciente e no meu coração."

(UISM, texto dedicado à pesquisadora/autora desta tese, elaborado por socioeducando, 17a)

onge de ser um dueto poético, este capítulo se dedica a um duplo caminho onde se
encontram vozes em contextos de situação distintos. Enquanto por um lado há
gritos de clamores que não devem passar ao largo da sociedade nos dias atuais, por outro há vozes que ecoam condutas de comportamento e disciplina. Desta forma, este capítulo tratará da análise das representações linguístico-discursivas dos adolescentes de duas instituições: do Colégio Militar de Brasília e da Unidade de Internação de Santa Maria. Serão apresentadas as análises realizadas em entrevistas com o(a)s estudantes do CMB e com os socioeducando(a)s da UISM, no intuito de investigar as representações desses adolescentes. Além disso, serão apontadas marcas linguístico-discursivas inerentes aos adolescentes no que concerne aos dois contextos da capital federal no momento em que se aproximam e/ou se afastam. Por fim, far-se-á a apresentação do Sistema de Avaliatividade e seus subsistemas. Cabe ressaltar, como mencionado, que as análises têm como aportes teóricos-metodológicos as propostas de Halliday (1994), Halliday e Matthiessen (2004), Fairclough (1992, 2003, 2010) e Chouliaraki e Fairclough (1999).

\subsection{RELAÇÕES LINGUÍSTICO-DISCURSIVAS NOS RELATOS DE ADOLESCENTES}

Esta subseção, dedicada aos discursos dos adolescentes/colaboradores, destaca as categorias linguístico-discursivas que foram identificadas e agrupadas de acordo com a natureza das recorrências encontradas. Os adolescentes da Unidade de Internação de Santa Maria e os do Colégio Militar de Brasília registraram, por meio do gênero Relato, suas 
experiências pessoais de acordo com a conversa e com os questionamentos realizados junto a eles. Trata-se de relatos muito significativos, não só devido às diferentes realidades e contextos, mas também às identidades, emoções, crenças, valores e perspectiva de vida dos participantes.

Nesse sentido, cabe lembrar Polanyi (1985, p. 9), para quem a linha do tempo no discurso narrativo é estabelecida e demarcada por momentos discretos nos quais ocorrências instantâneas (eventos) tomam lugar no mundo por meio do relato. No ato do relato, então, os adolescentes tornaram-se os donos do discurso, como uma forma de empoderamento, com o poder de voz que, por vezes, não é ouvida pela família, pela sociedade e pelo Estado.

Buscou-se fazer um paralelo por contraste, mediante a comparação dos discursos daqueles que estão acolhidos na Unidade de Internação de Santa Maria, com os dos alunos do Colégio Militar de Brasília, para apontar em que momento os discursos dos adolescentes se alinham e onde se afastam, bem como analisar, suas ideias a respeito dos sistemas em que estão inseridos. Os adolescentes colaboradores, que tiveram permissão para serem entrevistados e permitiram transformar seus depoimentos em dados aqui apresentados, apesar de pertencerem à mesma faixa etária, encontram-se distantes em ações, crenças e valores, a começar pela natureza do trabalho desenvolvido nas respectivas instituições.

Foram feitas as mesmas perguntas para os adolescentes dos dois contextos de situação, (CMB e UISM), as quais versavam sobre obediência, aprendizado nas instituições em que estavam inseridos e suas pretensões futuras. Pondera-se que o ato de percepção linguística, em termos de planejamento e execução, encontra-se evidenciado no cerne das respostas, como materialização da linguagem, em forma de relato. Cabe ressaltar, nesse sentido, que não será feita uma análise exaustiva de aspectos gramaticais, mas, sim, a observação de representações e significações tecidas durante os relatos.

Os discursos dos adolescentes foram categorizados, em termos de similitude, de acordo com as recorrências mais encontradas nos relatos. A primeira categoria foi a "paternidade como base de contrastes", na qual aspectos pertinentes à experiência, tanto positiva quanto negativa, foram relatados. A segunda foi a "relação social com a droga", em que se pode observar a relação de razão e consequência, estabelecida entre a droga e o crime. A terceira refere-se à "obediência", tema relevante na vida dos adolescentes dos dois contextos abordados. A quarta diz respeito ao "aprendizado nas instituições". A quinta categoria refere-se ao "futuro e pretensões" dos adolescentes. 


\subsubsection{Paternidade como base de contrastes}

A primeira categoria observada, devido às recorrências nos relatos, concerne à paternidade. O título "paternidade como base de contrastes" remete à influência paterna na vida dos adolescentes, seja de forma positiva, seja de forma negativa. Em ambos os contextos, tanto do Colégio Militar de Brasília como da Unidade de Internação de Santa Maria, a figura paterna, sendo o pai biológico ou não, pareceu ter grande influência nos atos e comportamento dos adolescentes. Cabe ressaltar que não foi feita uma pergunta específica a respeito do pai, mas houve a necessidade, por parte dos adolescentes de ambas as instituições, de relatarem importantes fatos referentes a seus pais. Observe-se, nos excertos seguintes, relações sociais negativas, entre pai ou padrasto e filho(a), ocasionadas pela violência doméstica, como se pode observar nos fragmentos abaixo. Vejamos.

(74) (Pesquisadora) Então, você hoje, com treze anos de idade, está me falando que você acha muito difícil sair ((da Unidade)), ser solto?

(Lucas) - Ó, eu saio, aí eu tenho medo dele ((padrasto)) me matá! Eu não vou ter como sair por causa da droga!

(Pesquisadora) - Mas você está em guerra ${ }^{29}$ ? Com esse padrasto? ... Essa guerra veio porque ele foi morar com a sua mãe?

(Lucas) - [ininteligível]...ele bateu na minha mãe! Eu ia matá ele dento de casa mas... direto, cando, não tava teno corage... Aí, comecei a tomar roupinol ${ }^{30}$, aí, eu peguei um revolve e subi lá pra cima, lá, dei três tiro nele.

(Pesquisadora) - Sério?! Mas esses tiros acetaram o seu padrasto?

(Lucas) - Acertô não, moça. Falaram que acertô no braço, mas eu acho que nem...

(UISM, relato de Lucas, 13a)

Lucas, no excerto (74), topicaliza sua fala para chamar atenção do seu dilema de vida, como se fosse uma súplica, quando utiliza o processo mental olhar, em forma de vocativo, retratado pelo $\underline{O}$ (olha). Relata uma relação assimétrica de poder, entre ele e o padrasto e evoca o processo material matar (processo concernente ao fazer/acontecer) duas vezes em sentido de reciprocidade: eu tenho medo dele me matá! e eu ia matá ele dento de casa. Tratase de um caso de violência doméstica que acarreta o sentimento de medo do adolescente de ser morto pelo padrasto ao sair da Unidade e voltar para casa. O conflito se deve, em primeiro lugar, à guerra com o padrasto, motivado por problemas com as drogas (não ficou claro se o padrasto era traficante ou se o problema era o próprio consumo de drogas do adolescente) e,

\footnotetext{
${ }^{29}$ Guerra: gíria que diz respeito à briga, muitas vezes, com ameaça de morte.

${ }^{30}$ Rupinol é um medicamento usado para reduzir a insônia. Entretanto, tem sido usado de forma abusiva como droga entorpecente.
} 
em segundo, pelos tiros alvejados em direção ao padrasto, por conta de sua revolta ao ver a mãe apanhar e sofrer castigos físicos. Faz-se necessário, ao se observar o termo guerra, lembrar Halliday (1986, p. 165-181) para quem uma antilinguagem está inserida em uma antissociedade, assim como a linguagem está dentro da sociedade. Para o autor, a antissociedade possui estrutura social específica e se estabelece dentro de outra sociedade como uma maneira de resistência hostil a esta. Destarte, a antilinguagem é considerada como um código que constitui, caracteriza e delimita o discurso (LOPES, 2003, p.91), que, no caso, configura-se como a ameaça de morte do padrasto.

Nesse contexto de violência, o socioeducando sente-se mais seguro recolhido na Unidade do que em seu próprio lar, junto à sua família, a qual deveria exercer a função social de educação e proteção. Sendo assim, observa-se a singularidade desses dados no momento em que a Unidade de Internação parece cumprir, apesar de não oferecer meios eficazes de ressocialização aos socioeducandos, seu papel de acolhedora desse adolescente que enxerga a instituição como sua casa, sentindo-se mais seguro ali.

(75) (Pesquisadora) E onde você morava?

(Ada)- Taguatinga.

(Pesquisadora) - Taguatinga? E o que levou você... Por que você veio para cá?

(Ada) - Porque eu... Desde pequena eu via meu pai bater na minha mãe, aí eu não gostava, eu ia pá rua e aprendi, na rua mermo!... É por isso. Eu não podia fazê nada!

(UISM, relato de Ada, 16a)

No fragmento (75), nota-se, também, um caso de violência doméstica. A situação de agressões, por parte do pai em relação à mãe, causou um sentimento de impotência na adolescente diante da rotina em que vivia. No segmento oracional eu não podia fazê nada, Ada parece demonstrar a impossibilidade de reversão desses acontecimentos com o uso do recurso léxico-gramatical modalizador podia, bem como do adjunto modal negativo não. Nesse conturbado contexto familiar, com um cenário de violência física, a adolescente ia para rua, lugar que simbolizava o lar que ela havia deixado para trás, como uma espécie de fuga. Na rua, Ada se sentia bem, pois não presenciava as agressões do pai em relação à mãe. A partir daí, começou na senda dos delitos.

Em ambos os casos, a violência paterna e o abandono geraram a desestrutura emocional dos adolescentes causando distorções no comportamento individual, o que resultou 
no consumo de drogas, na entrada no mundo da marginalidade e, por fim, no cometimento de atos infracionais. $^{31}$

Porém, em outro contexto, houve relatos, como os dos excertos abaixo, de condutas rígidas em relação aos filhos. Vejamos.

(76) Situação difícil todo mundo passa... Mas eu acho que a minha família é especial... Não que teve mais, mas eu acho que não soube lidar tão bem com isso! Meu pai é bipolar, e:::: E aí devido muitas doenças, morte na família, acabou causando depressão nos meus pais, em avós, eu também já passei por depressão, então, eu acho que:::: eu acho que eu sempre entendi plenamente o ponto de vista deles. Eu acho que só o que faltou, talvez, mais por parte do meu pai, que ele é, ele era militar também, ele tem esse jeito mais rígido. Então, eu acho que assim como os pais deveriam tê com os filhos, o Colégio também poderia tê mais espaço pra debate e conversas!

(CMB, relato de Ava, 16a)

No excerto (76), a rigidez parece estar representada, para Ava, pela falta de diálogo em casa com o pai, o que sugere um sentimento de carência paternal. Essa relação propiciou que ela entrasse em um quadro depressivo (faz tratamento com psicóloga e chegou a tomar medicamentos antidepressivos). Porém, quando diz que o pai é militar, observa-se um alinhamento da falta de diálogo, tanto entre ela e o pai militar quanto entre ela e Colégio. Considera-se que a estudante parece revelar ter consciência da importância de seguir regras que, em casa e na escola, muitas vezes, são inquestionáveis.

(77) Assim... Eu e meu padrasto, a gente não se dá muito bem! Assim... O meu pai, ele morreu quando eu tinha um mês de idade, então, eu nunca tive contato com ele assim, próximo, nem, eu só fui sabê disso com sete anos mais ou menos, na primeira série, que assisti as fitas cassete caseiras, da família... E a gente sempre teve uma relação muito árdua, sabe? Hoje em dia, a gente meio que é... Num se fala tanto! Mais eu lembro que, foi no sétimo ano, que eu briguei muito feio com ele! Muito feio mesmo! Coisa boba! Me arrependo até hoje, mais... Assim, foi uma discussão muito feia meeesmo! Quase deu polícia lá em casa! Só não, chamaram, ligaram pro porteiro, o porteiro só não ligou pra polícia porque ele conhecia a gente, era amigo íntimo! Tão... É, a gente sempre teve uma relação meio... De bastante atrito, desde pequenininho, sabe? Ele era sempre bastante rígido! ... Mas agradeço até hoje, por toda essa rigidez, embora eu não tenha gostado, na época. Eu acho... Eu acredito assim, que foi devido a essa rigidez que hoje eu... Eu tô como eu tô! Sabe? Eu tô... Estudioso! Minha mãe que pede pra eu pará de estudá! Tá? Eu gosto de estudá, estudá pra mim é um prazer! Qualqué área, assim, é um prazê imenso pra mim! É obter conhecimento!

(CMB, relato de Moisés, 17a)

31 Art. 103. Considera-se ato infracional a conduta descrita como crime ou contravenção penal. (Estatuto da Criança e do Adolescente) 
Já no fragmento (77), Moisés relata a falta de diálogo entre ele e o padrasto na unidade de informação hoje em dia, a gente meio que é... num se fala tanto. Como recurso para exacerbar a distância no convívio entre os dois, utiliza o adjunto modal de intensidade muito em alguns enunciados como a gente não se dá muito bem, a gente sempre teve uma relação muito árdua, eu briguei muito feio com ele! Muito feio mesmo, foi uma discussão muito feia meeesmo. Contudo, embora tenha uma relação um pouco conturbada, devido ao jeito rígido do padrasto, expresso no enunciado ele era sempre bastante rígido, Moisés parece enxergar a rigidez como uma característica positiva para seu crescimento pessoal, pois, segundo ele, seu gosto pelo estudo se deve à forma rígida de tratamento exercida pelo padrasto.

Em contrapartida, há, nos relatos, em situação contrastiva, a figura paterna como alguém que incentiva, não age de maneira rígida com o filho, tampouco com faz uso da violência, mas em forma de incentivo e diálogo, como se pode observar abaixo.

(78) Eu sou concursada, né? E aí eu fiz, meu pai, ele sempre me incentivou a vir pra cá. Até porque, no começo, eu nem queria fazer cursinho - fiz um cursinho - eu nem queria fazer cursinho, mas ele me incentivou, eu fui pra eu testar, né? Porque, quando a gente testa, tem como falar sobre aquilo, sobre aquilo. Aí, é... Eu fiz o cursinho e eu gostei muito do cursinho, e eu fiz a prova, só que eu não consegui passar. Aí, por eu ter gostado muito, eu não achei que seria, eu era adiantada na época, não achei que seria um problema se eu fizesse de novo o cursinho pra testar. Aí eu fiz e eu me apaixonei assim, e, pelo cursinho e por toda essa forma que eles tinham de metodologia, e aí, eu passei no Colégio Militar, e aí eu tomei essa decisão de vir pra cá estudar! E aí, eu voltei um ano e eu vim estudando de novo!

(CMB, relato de Isabel, 17a)

O discurso apresentado, no fragmento (78), é iniciado por uma unidade de informação, em que a aluna dá destaque à sua própria característica por meio do Atributo concursada. Note-se que a oração inicial de seu discurso parece vir como um prêmio, uma conquista de suma importância para a adolescente. Não obstante, também chama atenção o processo mental incentivar, utilizado duas vezes no segmento oracional: meu pai, ele sempre me incentivou a vir pra cá... eu nem queria fazer cursinho, mas ele me incentivou, eu fui pra eu testar, né?. Observa-se que essa escolha lexical permite Isabel mostrar a presença afetiva paterna em sua vida, procurando destacar, na linguagem, o papel do pai, como incentivador e não como alguém que a tenha obrigado a fazer o concurso, ou a fazer o cursinho de forma impositiva e obrigatória.

Assim como no caso de Isabel, as relações paternas, nos relatos desta subseção, Paternidade como base de contrastes, tiveram grande influência na visão de mundo dos 
adolescentes e, consequentemente, em suas identidades. A fragilização dos vínculos afetivos, causada, por vezes, em decorrência de atos violentos, causou nos adolescentes sentimentos de medo, impotência e carência. Entretanto, por outro lado, pôde-se observar como fatores positivos o reconhecimento e a gratidão na relação entre pais e filhos.

\subsubsection{Razão e consequência: o vício e as drogas em conectividade com os delitos}

A maioria do(a)s socioeducandos relatou que fazia uso de drogas lícitas e ilícitas, em uma escala contínua, ou seja, desde o uso de bebidas alcoólicas, a entorpecentes como maconha, passando por cocaína, rupinol até o crack. Em suas falas, em relação ao uso de drogas e ao crime cometido, foi observado um número significativo da estrutura de relação de razão e consequência. Nesse sentido, cabe, aqui, evocar Garcia (2004, p. 240), para quem uma "apresentação de razões e consequências ocorre quando se trata de justificar uma declaração ou opinião pessoal a respeito de atos ou atitudes do homem". No caso dos adolescentes acolhidos na UISM, eles trazem justificativas com razões e consequências para revelar seu mundo experiencial que emerge do submundo das drogas.

Cabe aqui ressaltar que não se deve confundir razão e consequência com causa e efeito. Ainda, conforme Garcia (2004, p. 240), deve-se abordar a relação causa e efeito "quando se procura explicar fatos e fenômenos, quer das ciências naturais, quer das sociais". Segundo o autor, os atos ou atitudes praticados pelo homem têm razões, motivos ou explicações e somente os fatos ou fenômenos físicos têm causa. As relações causais explicam como os eventos surgem em uma relação crítico-realista. ${ }^{32}$ Sendo assim,

existe um nível de realidade abaixo do nível de eventos onde ocorrem as observações empíricas. É uma dimensão profunda cujos mecanismos fazem os eventos acontecerem. As causas são sobre os objetos ou as relações e suas naturezas. Os poderes causais podem ser localizados nas relações sociais ou em estruturas que as pessoas constroem. (BARROS, 2015, p. 106-107)

Dessa maneira, os fatos ou fenômenos físicos são concernentes às causas e os atos ou atitudes praticados ou assumidos pelo homem, nesse caso os socioeducandos, referem-se às razões. Partindo-se desse pressuposto, nos excertos apresentados abaixo, podem ser notados os mecanismos de razão e consequência, na categoria relação social com a droga, bem como

\footnotetext{
32 A proposta teórica do "Realismo Crítico", cujo expoente é reconhecido no filósofo contemporâneo Roy Baskar (1978, 1998), encontra-se detalhada em Barros (2015): Realismo crítico e emancipação humana contribuições ontológicas e epistemológicas para os estudos críticos do discurso.
} 
de causa e efeito que fazem os eventos ocorrerem. Para ilustrar a relação de razão $\leftrightarrow$ consequência e causa $\leftrightarrow$ efeito, foi construído o seguinte Gráfico:

\section{Gráfico 5.1 - Demonstrativo de níveis de razão e consequência}

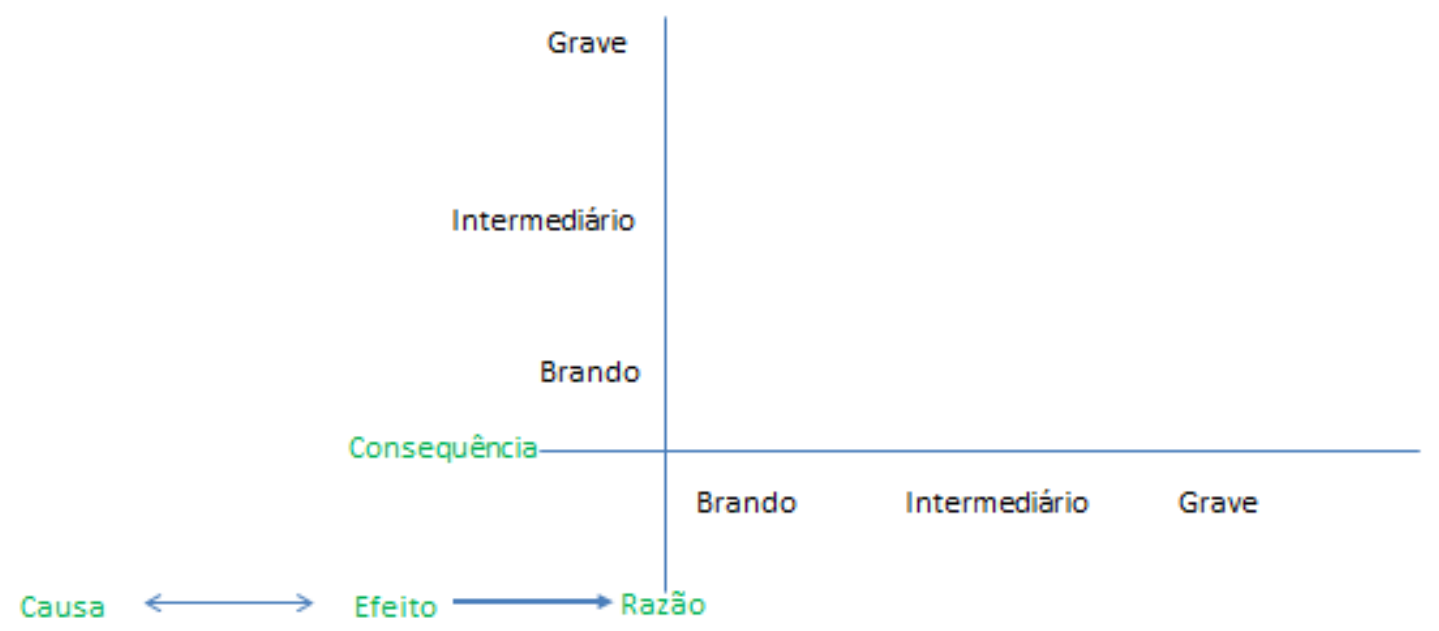

Fonte: elaborado pela autora

Em um contexto de fatos e fenômenos, encontram-se a causa e o efeito. Já em um contexto de atos ou atitudes dos adolescentes, encontram-se a razão e consequência. Na maioria das entrevistas, pôde-se notar como causa comum, na vida dos socioeducandos, a falta de estrutura familiar o que parece ter acarretado a vulnerabilidade pessoal de alguns adolescentes da UISM. Seguindo essa linha, pôde-se identificar um continuum de razões (da mais branda para a mais grave), com suas respectivas consequências, de mesma intensidade, que os levaram a um análogo fim, qual seja, o da criminalidade seguido da internação. Apreciemos três casos que retratam a relação linguística de razão e consequência nos excertos abaixo.

\section{Razão:}

(79) É... Eu ia pa escola, nunca parei de estudá...Aí, é, eu ia pa festas. Festas que a gente combinava na escola. Aí depois já... Começava a usá drogas, assim já arrumei otas amizades. Aí fui ino pa esse ôto lado. Já usei maconha, cocaína, lança-perfume, já usei quase, roupinol. 


\section{Consequência (apreendido por ter praticado roubo):}

(80) Ah! Purque na hora eu num pensei assim, eu também tava... Tava sob uso de, tinha tomado, usado droga, tomei roupinol, aí eu tava fora de si assim... Aí nem pensei nas consequências, já fui.

(UISM, relato de João Batista, 16a)

Pode-se notar, segundo os excertos (79) e (80), que ocorreu uma sequência de motivos com as devidas consequências culminando, como relatado pelo adolescente durante a entrevista, no delito de roubo ${ }^{33}$. Observa-se, abaixo, o Gráfico que ilustra essa assertiva, como demonstrativo do relato de João Batista:

\section{Gráfico 5.2 - Demonstrativo da relação linguística de razão e consequência em relato de socioeducando}

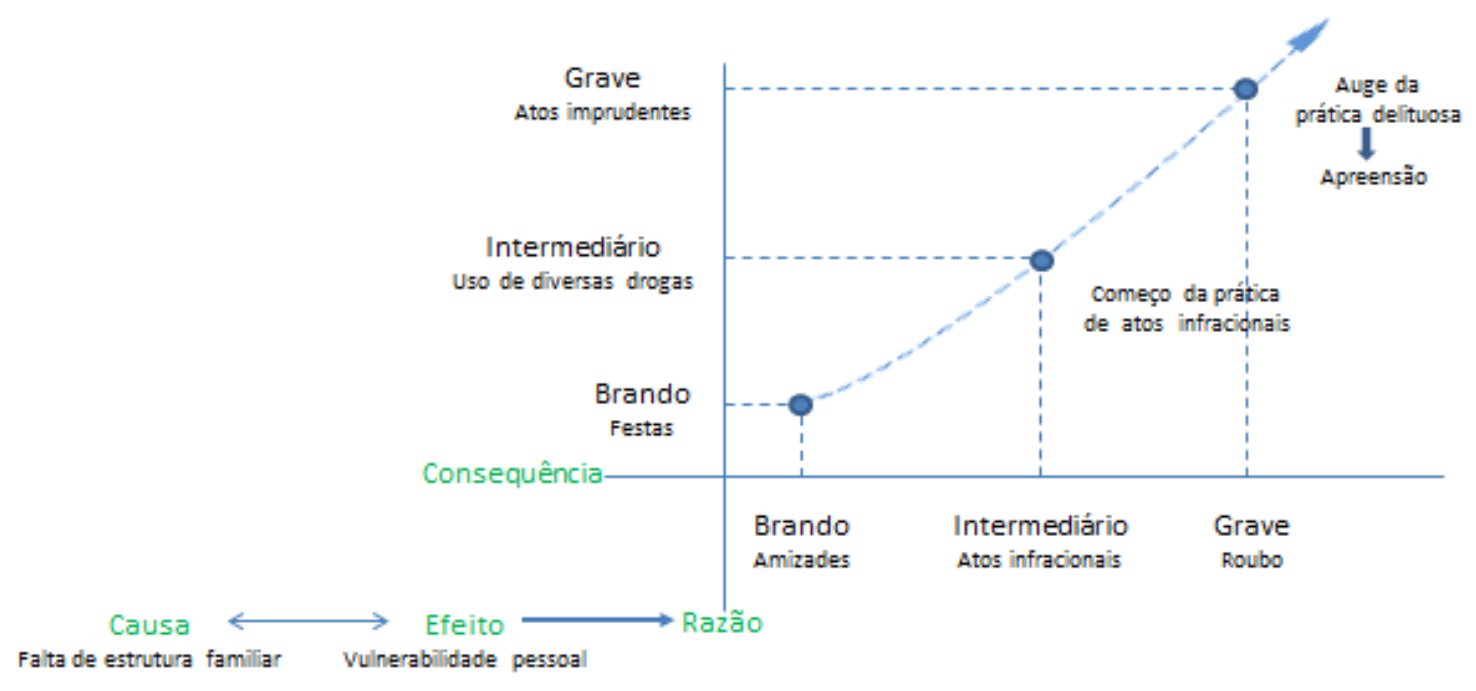

Fonte: elaborado pela autora

No Gráfico 5.2, observa-se a relação da causa (falta de estrutura familiar) e efeito (vulnerabilidade pessoal) resultante em razões e consequências, as quais se encontram em um processo continuum, em que se pode identificar três etapas: a branda, a intermediária e a grave.

Em um primeiro momento, o socioeducando informa ter ido a festas e, durante os eventos, aproximou-se de pessoas, com quem estabeleceu um vínculo de amizade, que lhe

\footnotetext{
${ }^{33}$ Art. 157 - Subtrair coisa móvel alheia, para si ou para outrem, mediante grave ameaça ou violência a pessoa, ou depois de havê-la, por qualquer meio, reduzido à impossibilidade de resistência. (Código Penal Brasileiro)
} 
apresentaram as drogas. Devido a esse motivo, mergulhou no mundo do vício ao passar a consumir drogas diversas, como maconha, cocaína, lança-perfume e rupinol, que o estimularam a cometer pequenos delitos. Por fim, sem pensar nos atos praticados, chega ao cometimento do delito de roubo. No topo de associação, encontra-se a prática de atos infracionais.

Como em um círculo vicioso, se não houver uma quebra desse contínuum, poderá ocorrer a prática continuada dos atos delituosos cometidos pelo adolescente. Nesse sentido, o retorno à casa de recolhimento (Unidade de Internação) implicará a reincidência de delitos. Pode-se ponderar que se não houver uma (re)educação e uma ressocialização desse adolescente, a reincidência de suas entradas nas Unidades de Internação será o breve caminho para as penitenciárias, as masmorras da vida, e a partir dessas, talvez, até, chegue ao óbito.

Observemos, a seguir, outros casos semelhantes com características de razão e consequência nas narrativas dos socioeducandos da UISM que trazem, como topo, o cometimento de infrações:

\section{Razão:}

(81) Eu, tipo eu comecei na escola, né?, conheci uas amizade, aí minha mãe nem sabia não, depois de um tempo ela foi saber... Cando meu... Meu pai morreu, o meu padrasto, eu já comecei já, já, já... se envolvê já co os maus elementos já na rua, já, já comecei usá droga, ai chegou pivete assim: "aí, qué vendê droga pra mim, não?"

(UISM, relato de Lucas, 13a)

\section{Consequência (apreendido por ter praticado roubo):}

(82) Comecei a usá droga... Aí comecei a robá, já, moça!

(UISM, relato de Lucas, 13a)

No excerto (81), observa-se, na narrativa de Lucas, a exposição das razões de ele chegar à consequência evidenciada que, nesse caso, são os roubos. Os enunciados apresentam informações sobre como ele iniciou sua vida no cometimento de infrações. Nota-se o uso sequencial de processos para demonstrar as razões. O adolescente em conflito com a lei utiliza o processo material começar, que, nesse caso, traz a existência atos (razões) que levam a uma consequência. Primeiramente, o processo começar em "eu, tipo eu comecei na escola, né?" conduz o início do encadeamento de ações que, para o próprio Ator, não são corretas. Logo após, há ocorrência do processo mental conhecer, evidenciando a percepção de que as 
amizades não eram adequadas. Isso é corroborado com o processo material começar e com a circunstância de acompanhamento maus elementos, utilizado em eu já comecei já, já, já... se envolvê já co os maus elementos já na rua, já, já comecei usá droga. No fragmento (82), há explicitamente a relação de razão e consequência, como se pode observar em: comecei a usá droga... Aí comecei a robá, já, moça!. Cabe destacar, nesse segmento oracional, que o marcador discursivo aí introduz, além de uma relação temporal, uma relação de consequência, que é o ato de roubar. Abaixo, veremos mais um caso dessa relação de razão e consequência.

\section{Razão}

(83) A primeira droga que eu usei foi cocaína! Foi a primeira droga que eu usei. Com sete eu já fumava cigarro, escondido. Eu já fumava cigarro escondido. Com dez a primeira droga que eu usei foi a cocaína, depois eu comecei fumar maconha... E assim fui ino... Aí acabou que eu já entrei, comecei a vender droga, aí minha mãe chegou ni mim, minha mãe desconfiava, né? Que eu chegava em casa com o olho muito vermelho, muito baixa... Aí ela chegava ni mim, e peguntava pra mim... Que que eu tava fazendo, onde eu peguei e contei toda a verdade pra ela! E pronto!

(Pesquisadora) Chegou a usar crack?

(Maria Madalena) Cheguei!

(UISM, relato de Maria Madalena, 17a)

\section{Consequência (apreendida por ter cometido homicídio):}

(84) Envolvimento foi de dinheiro e droga. Eu tava vendendo droga e... Ele me deu uma nota de cinquenta reais falsa... E como eu tava, na hora eu num parei pa pensar o que eu ia fazer, porque até então eu tava drogada, tava bêbada, tava inconsciente, num tava sabendo o que eu tava fazendo no exato momento...

(UISM, relato de Maria Madalena, 17a)

Nos excertos (83) e (84), também é encontrada a relação de razão e consequência. No fragmento (83), há predominância de processos materiais que estabelecem a mudança do fluxo dos eventos realizados por usar, começar, fumar. Cabe ressaltar que o uso dos marcadores sequenciadores de relações temporais já, depois, assim, aponta para uma sequência narrativa cronológica que indicia a consciência dos atos praticados pela adolescente nos fatos relatados de forma encadeada. Em: com sete eu já fumava cigarro escondido, com dez a primeira droga que eu usei foi a cocaína, depois eu comecei fumar maconha... E $\underline{\text { assim }}$ foi ino nota-se uma forte expressão da sequencialização para demarcar o indicador de tempo. No excerto (84), nas orações relacionais, os Atributos caracterizam o Portador, como em: eu 
tava drogada, tava bêbada, tava inconsciente. Isso parece evidenciar a construção de uma pessoa com a identidade enfraquecida que, apesar de parecer ter a noção de seus atos, como se observa no enunciado já fumava cigarro escondido, com dez a primeira droga que eu usei foi a cocaína, depois eu comecei fumar maconha torna-se alguém sem perspectiva de crescimento pessoal, na medida em que se entregou às drogas e para o mundo do crime.

Os três socioeducandos, João Batista, Lucas e Maria Madalena, constroem, em seus discursos, relações de razões e consequências que advêm de uma causa, observada como a falta de estrutura familiar e um efeito aparente de vulnerabilidade pessoal. No tocante à questão das drogas, cabe evocar as palavras de Montecino e Vidal (2011):

uma verdadeira solução para o problema social do consumo de drogas deve
partir de uma melhoria substancial das condições de vida das famílias em
situação de pobreza a qual permita que possam construir laços de
solidariedade, de forte apoio e de relações pessoais positivas entre seus
membros. Para tanto, é necessário olhar de maneira muito mais profunda o
problema da pobreza, suas causas e as repercussões que têm na vida das
pessoas, além de considerar o que elas mesmas têm a dizer acerca de seus
problemas, seus obstáculos, suas possibilidades e suas esperanças.
(MONTECINO; VIDAL, 2011, p. 107)

Nesse diapasão, observa-se que o consumo de drogas repercute na construção da imagem desses adolescentes no discurso, ou seja, no ethos, pois se revelam como pessoas com vulnerabilidade pessoal e, por vezes, social. No caso de João Batista, Maria Madalena e Lucas, não existem relações pessoais positivas entre eles e suas famílias, tampouco laços de solidariedade e apoio, nem do Estado, nem da família. De acordo com Mainguenau (2006, p. 56), a questão do ethos está ligada à construção da identidade. No caso dos adolescentes da Unidade de Internação de Santa Maria, o ethos discursivo vai sendo construído gradativamente na enunciação como demonstrado na relação linguística de razão e consequência. Pode-se observar essa gradação, no caso de João Batista, Maria Madalena e Lucas, com os processos materiais transformativos ir e começar utilizados para seguir em direção ao crime: aí fui ino pa esse ôto lado (João Batista), e assim fui ino... Aí acabou que eu

\footnotetext{
34 Tradução livre da autora de "una verdadera solución al problema social del consumo de droga debe partir desde una mejora sustancial de las condiciones de vida de las familias en situación de pobreza que permita que estas puedan construir lazos de solidaridad y de apoyo fuertes y relaciones personales positivas entre sus miembros. Para ello, es necesario mirar de manera mucho más profunda el problema de la pobreza, sus causas y las repercusiones que tiene en la vida de las personas, además de considerar lo que ellas mismas tienen que decir acerca de sus problemas, sus obstáculos, sus posibilidades y sus esperanzas." (MONTECINO; VIDAL, 2011, p. 107).
} 
já entrei, comecei a vender droga (Maria Madalena) e eu já comecei já, já, já... se envolvê já co os maus elementos (Lucas).

\subsubsection{Obediência}

A categoria "obediência" foi pensada antes das entrevistas feitas aos socioeducandos e aos alunos do CMB. Isso porque esta pesquisa envolve dois contextos de duas instituições que utilizam o discurso disciplinador voltado para a obediência. Obedecer vem do latim Obedire, que concerne a se submeter à vontade de outrem; executar as ordens de alguém; ceder a alguma coisa (CALDAS AULETE, 1958, p. 3513). Pode-se dizer que obediência relaciona-se com ordem. Nesse sentido, conforme Casteleiro (2014, p. 45), "ordem" supõe dois ou mais interlocutores, entre os quais se trava um diálogo relativamente ativo. Esse diálogo se estabelece entre a primeira e a segunda pessoas do discurso. De um lado está a pessoa que ordena, ou o ordenante; de outro, a pessoa que ouve, ou ouvinte. Porém, o ouvinte também é participante do discurso ativo, já que pode assentir à ordem ou se opor a ela.

Nesse tirocínio de ordem e obediência, foram feitas as seguintes perguntas, tanto para os socioeducandos, quanto para os alunos: o que é obediência para você? O que é obediência dentro da instituição? Como respostas, foram notadas características como resistência, limite e respeito, as quais foram consideradas como subcategorias da categoria obediência. Vejamos alguns relatos dos adolescentes da UISM e do CMB referentes à obediência.

\subsubsection{RESISTÊNCIA}

Resistência é uma subcategoria encontrada na fala tanto do adolescente da UISM quanto do CMB. Resulta que foram notados, nos relatos, uma interseção entre relações de poder, obediência e resistência em determinados discursos. A respeito da relação entre poder e resistência, em Foucault, Revel (2005) salienta que

a resistência se dá, necessariamente, onde há poder, porque ela é inseparável das relações de poder, assim, tanto a resistência funda as relações de poder, quanto ela é, às vezes, o resultado dessas relações; na medida em que as relações de poder estão em todo lugar, a resistência é a possibilidade de criar espaços de lutas e agenciar possibilidades de transformação em toda parte. (REVEL, 2005, p.74) 
Destaque-se que, apesar de pertencer à mesma subcategoria, a resistência foi subdividida, segundo as observações dos excetos, em duas formas: a externa, de acordo com as ações, e a interna, de acordo com o pensamento. Apreciemos.

(85) (Pesquisadora) E aqui dentro, o que é obedecer pra você? Aqui? (David) É de boa, tem que sigui regras. Tô obedeno a regra.

(Pesquisadora) E você obedece a essas regras?

(David) Obedeço. Quase toda, mar tem umas que num dá pra obedecê não.

(Pesquisadora) É? Quais, por exemplo, não dá para obedecer?

(David) Qui num pode pidi nada, senão eles vai ficá, eles deixa de medida. Aí tipo, eles tá, bota numa regra que num dá pa obedecê.

(Pesquisadora) Hum rum. Pedir o quê?

(David) Pidi alguma coisa pos agente, eles num, eles fica chateado, fica bravo. Aí tipo, qué que nóis obedece eles, né?, nessas questão aí...

(Pesquisadora) Mas pedir o que, especificamente?

(David) Pidi alguma coisa, pidi uma técnica, chama um chefe de segurança... Os bicho fala que num vai. Tem que ficá calado dento do quarto. Caí eu já num falo, falo que vô ficá calado não! Aí eles deixa eu de medida...

(UISM, relato de Abraão, 16a)

A fala de Abraão, no excerto (85), envolve três instâncias: a obediência, a resistência e a punição. Na categoria obediência, ele imprime sua marca com a expressão da modalidade no eixo da conduta, ou seja, a deôntica com componente de modalização ter em tem que sigui regras, sinalizada por uma "obrigação material, externa, ditada por imposição de circunstâncias externas" (NEVES, 2011, p. 174). Além disso, o adolescente parece ter consciência de que deveria obedecer às regras impostas pela instituição. Entretanto, quando pergunto se ele obedece às regras impostas, ele responde que quase toda, mar tem umas que num dá pra obedecê não. Dessa forma, pode-se notar, nessa relação assimétrica de poder, uma resistência do adolescente a determinadas regras, situação em que podem ser evocadas as palavras de Foucault (1985, p. 91) ao explicitar que “onde há poder, há resistência”, tornandose evidente o caráter relacional das relações de poder, tanto por parte de determinados agentes de polícia, quanto por parte do socioeducando, pois há regras as quais o socioeducando deveria obedecer, mas não o faz e, por isso, fica submetido a medidas disciplinares.

Essas relações de poder podem ser assinaladas por ações externas de resistência do socioeducando, na medida em que, por um lado, ele não se cala e por outro, há as punições devido às suas próprias ações. Ilustra-se essa assertiva com o seguinte segmento oracional: tem que ficá calado dento do quarto. Caí eu já num falo, falo que vô ficá calado não! Aí eles deixa eu de medida. Em contrapartida, nota-se, na fala do aluno do $\mathrm{CMB}$, um comportamento 
totalmente contrário ao desse adolescente em conflito com a lei, mas que, entretanto, reflete também uma resistência. Observemos.

(86) Eu acho que obediência, tipo, num sentido mais literal, é você... Aceitar calado! Aceitar sem questionar. Por mais que você discorde, é:::: Aceitá calado! Sem questionar e sem reclamar. Pra mim acho que obediência é isso! Por mais assim: errôneo que isso pareça, obediência pra mim, é isso!

(CMB, relato de Moisés, 17a)

No excerto (86), Moisés reproduz um discurso de submissão. Parece haver um sentimento de subserviência, seja por formação, seja por educação, seja por instrução. Cabe destacar que ele, internamente, parece discordar do seu próprio comportamento de aceitar tudo sem questionamentos e calado, como se pode observar no enunciado por mais assim: errôneo que isso pareça. Contudo, nota-se que o adolescente considera a obediência como uma regra interna para ele. A resistência, nesse caso, é interna. Ele acata e aceita a ordem, sem questionamentos ou reclamações, em uma relação de comando/submissão. Esse comportamento, expresso em seu relato, pode fazer alusão a um comportamento militar hierárquico.

De forma passiva, talvez para chegar aonde quer, por medo ou mesmo para não ter adversidades com outras pessoas, o aluno não se expressa por meio de atos ou fala e aceita o que lhe é ordenado. Já o socioeducando expressa em atos o que concorda ou não dentro da Unidade de Internação e parece não pensar, muitas vezes, nas consequências posteriores daquela ação. Outra subcategoria encontrada na obediência foi a de limite. Assim como na subcategoria de resistência, foi observada a subcategoria de limite nos dois contextos: o da UISM e do CMB.

\subsubsection{LIMITE}

A segunda subcategoria de obediência diz respeito ao limite. Limite envolve regras e princípios a serem seguidos, dentre eles, horários e valores que deveriam ser estabelecidos, primeiramente, pela família e, depois, pela escola, a fim de que as crianças e os adolescentes desenvolvessem o entendimento de convivência em sociedade. Para Castro (2002),

limites são regras ou normas de conduta que devem ser passadas para as crianças desde a mais tenra idade, pois a imposição de limites é parte essencial da educação de uma criança, possibilitando melhor equilíbrio quanto ao seu desenvolvimento moral, psíquico, afetivo, cognitivo, organizando suas relações sociais. Ao colocar regras para as crianças, as 
preparamos para a vida real, onde nem tudo acontece do jeito e na hora que se quer. Portanto, durante o processo de desenvolvimento, é importante saber que a lei na criança é internalizada, pois ela nasce amoral por ainda não ter internalizado as regras e aos poucos se torna capaz de moralidade quando guarda para si as leis. (COSTA, 2002, p.22)

Nessa tangente, a educação com limites almeja propiciar a conscientização dos atos e da fala das crianças e, posteriormente, dos adolescentes, a fim de que se desenvolva e seja internalizado o senso de responsabilidade pessoal e convivência social adequada. Entretanto, a noção de limite, em alguns casos, não é internalizada pela criança e pelo adolescente como se deveria, pois a família não consegue cumprir o papel de educadora de forma prudente, seja por descaso, seja por abandono, seja por falta de tempo, seja por delegar a função de educar para terceiros ou mesmo por cometer excessos em deixar as crianças e os adolescentes livres para decidirem o que quer que seja a respeito de suas próprias vidas. No excerto (86), foi observado que a falta de limite da adolescente em conflito com a lei decorre da situação de abandono da família. Vejamos.

(87) (Ada) Ah que, lá fora, é porque meus pais falava que... eu num queria vê aquilo ((ver o pai batendo na mãe)), aí eu ia pá rua. E aqui não, aqui nóis já aprendeu as disciplina. $O$ que eles fala nóis têm que cumpri... É daí, vai aprendendo... A medida socioeducativa... Os horário, os lanche, almoço, jantar.

(Pesquisadora) E isso, você acha que é favorável, que ajuda vocês?

(Ada) Com certeza!

(UISM, relato de Ada, 16a)

No excerto (87), Ada relata que, por não conseguir ver o pai agredir fisicamente a mãe, ia e ficava sempre na rua. Deixa subentendido que não tinha horário, tampouco limites em casa, sendo "criada" pela rua e não pela família. Porém, com sua apreensão e consequente ida para a Unidade, começou a ter a noção de limites, pois, anteriormente, ela parecia não saber o que eram regras, porque vivia nas ruas de forma desorientada e desordenada, sem horários, sem compromisso, sem limites impostos pelos pais.

Com o uso das circunstâncias aqui (circunstância de localização) e já (circunstância de tempo), a adolescente parece demonstrar que a Unidade de Internação propiciou a construção da ideia do que possa ser limite, bem como de medida socioeducativa para ela. Conforme a declaração da adolescente, nos segmentos oracionais, aqui nóis já aprendeu as disciplina. $O$ que eles fala nóis têm que cumpri... É daí, vai aprendendo... A medida socioeducativa... Os horário, os lanche, almoço, jantar, na Unidade de Internação, são estabelecidos e devem ser 
cumpridos horários específicos, ou seja, regras que desencadeiam uma conduta disciplinar. Vale ressaltar, no caso de Ada, que a instituição socioeducativa faz o papel social da instituição família. Isso, porque a UISM determina regras à socioeducanda que devem ser cumpridas e acatadas, regras sociais básicas que deveriam ter sido estabelecidas no ceio familiar. Observe-se, também, que a adolescente confirma a importância dessa noção de limite concebida na instituição com a expressão com certeza. Além da fala referente a limite de Ada, pôde-se observar a do aluno do CMB. Vejamos.

(88) Obedecer pra mim, é como se fosse... Como posso dizer? Existem regras que era... Pra padronizar, né? Assim, tipo assim, pra ter uma melhor... Convívio! Eu acho que o fato de você obedecer, você só, fica suscetível a... A, dentro dessas regras, e a um... A um meio de... Um meio social que você tá inserido. Obedecer quando seus pais falam: "não faça isso!", você realmente não faz isso! Você escuta as pessoas, escuta o conselho, e você fala: "Beleza, não vou fazer isso!"

(CMB, relato de Samuel, 16a)

No excerto (88), Samuel relata um meio de impor limites e de acatar o que foi dito. Segundo ele, obediência está ligada a regras que existem para que haja padronização e um melhor convívio social. Obedecer, para o adolescente, relaciona-se com o limite imposto pelos pais quando dizem não faça isso e ele não o faz. Há, nesse caso, um engajamento no discurso do estudante em relação a um ordenamento ou um comando veiculado pela oração encaixada. Ressalte-se que os limites parecem ocorrer em forma de diálogo e de conselhos, o que acarreta a conscientização, por parte do adolescente, do que deve ou não ser feito.

Dessa forma, nota-se, nos excertos (87) e (88), que os adolescentes das duas instituições parecem entender a importância das regras impostas e dos limites estabelecidos, seja por normas, seja por conselhos. Observa-se, também, que a família tem grande responsabilidade na formação de um ser consciente de seus direitos, dos seus deveres, de suas responsabilidades e atitudes e no desenvolvimento social e emocional da criança e do adolescente. Abaixo, veremos a última subcategoria de obediência: respeito.

\subsubsection{RESPEITO}

A terceira subcategoria de obediência encontrada nas falas dos adolescentes foi o respeito. Respeitar significa, dentre outros sentidos, tratar com reverência ou acatamento, honrar, recear, ter em consideração, procedimentos remetidos a premissas básicas das relações 
sociais. Nos dois contextos, da UISM e do CMB, os adolescentes relacionaram obediência a respeito, como veremos abaixo.

(89) Obediência. Obe... Saber respeitar os agente ou as outras interna, respeitar o espaço de cada uma pra ninguém desrespeitar o meu espaço também.

(UISM, relato Marta, 14a)

No fragmento (89), Marta parece julgar importantes as suas relações interpessoais de dentro da Unidade de Internação, quais sejam, as relações de convivência com os agentes e com as outras meninas internas. Há uma delimitação de espaços, quer o físico, quer o comportamental. A adolescente parece compreender a dimensão espacial pessoal, social e coletiva quando emprega, em seu discurso, os processos materiais antônimos respeitar e desrespeitar, como no enunciado: respeitar o espaço de cada uma pra ninguém desrespeitar o meu espaço também. O contrato social (Fairclough, 2003, 2010), nesse sentido, não é alterado, pois com o respeito, as relações sociais, dentro da Unidade de Internação, permanecem estáveis e, de certa forma, harmoniosas em uma estrutura dialética da prática discursiva, ou seja, a de respeitar para ser respeitada. Como se pôde notar, a relação de obediência e respeito apareceu na fala de Marta. Essa conexão linguístico-discursiva também é observada no relato da estudante do CMB, como se pode observar abaixo.

(90) Obediência, pra mim, é uma forma de respeito muito grande! Que deve ter pessoalmente com os mais velhos, com seus pais, seus professores, porque é uma forma de respeito, é uma forma de você demonstrar que você... É, não inferior, mas você tem menos experiência que aquela pessoa mais velha! Então, se ela determinar algo pra você, é bom você cumprir!

(CMB, relato de Cefira,16a)

Cefira, no fragmento (90), também faz a associação à obediência e ao respeito. A adolescente determina obediência, por meio do Processo Relacional, como uma forma de respeito muito grande. Parece demonstrar que compreende a noção de respeito em todas as instâncias em suas práticas sociais: na família, com os pais; na escola, com os professores; no dia-a-dia, com os mais velhos. Além disso, nota-se que, ao respeitar, a estudante parece enxergar, nessa relação hierárquica, para ela harmoniosa, um resultado que poderá beneficiála, pois se uma pessoa com mais idade que ela determinar que seja feito algo, é recomendável e sensato que o ordenamento seja cumprido, como pode ser observado no segmento oracional mas você tem menos experiência que aquela pessoa mais velha! Então, se ela determinar algo pra você, é bom você cumprir! . 


\subsubsection{Aprendizado nas instituições}

A categoria Aprendizado nas instituições foi elaborada devido à pergunta feita para os adolescentes a respeito do que eles aprendiam na instituição. Não houve, na fala dos socioeducandos, uma resposta positiva a respeito do aprendizado, seja na área educacional, seja na profissionalizante, no contexto da UISM. Por outro lado, os relatos dos estudantes do CMB parecem demonstrar que o ensino e o aprendizado procuram construir valores, bem como oferecer condições de acesso ao conhecimento. O aprendizado, para Oliveira (2006),

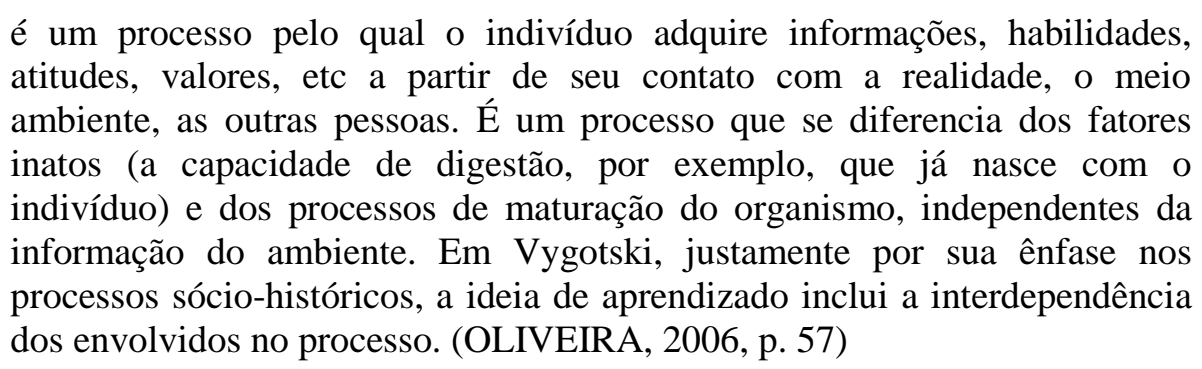

Dessa maneira, aprendizado envolve aquele que aprende e quem ensina, a relação entre os envolvidos, o contexto e a forma como esse aprendizado é desenvolvido e, consequentemente, internalizado. Vejamos de que maneira esse aprendizado é externado pelos adolescentes nas duas instituições em tela.

(91) Aprendi... De que num voltá mais, isso aqui num é vida pra ninguém não. Só isso que eu aprendi.

(UISM, relato de Abraão, 16a)

De acordo com o excerto (91), Abraão relata que o único aprendizado que teve dentro da Unidade de Internação foi a certeza de não querer mais voltar para lá. No enunciado isso aqui não é vida pra ninguém parece haver a desconstrução da ideia de que são estabelecidas ações sociopedagógicas e educativas efetivas e, principalmente, eficazes, que visem à formação e à construção da cidadania, como reza o Projeto Político Pedagógico das Medidas Socioeducativas no Distrito Federal (2013). Note-se que o socioeducando utiliza a circunstância adverbial só e o elemento anafórico isso para retomar a informação do co-texto à esquerda de maneira afirmativa em De que num voltá mais, isso aqui num é vida pra ninguém não. Só isso que eu aprendi. Dessa forma, Abraão sinaliza que os dias vividos, na instituição, parecem não ter contribuído para um aprendizado que deveria fazer parte de sua ressocialização e reeducação social. No fragmento a seguir, observa-se a similaridade de opinião, com um diferencial: o projeto de leitura. Apreciemos. 
(92) Aprendê, aprendê, não! Mar, vem de você, dá gente mermo, de procurá mudança, de vê porque é que a gente veio pará aqui! Como é o tratamento que a gente recebe aqui, procurá uma coisa diferente! Ah, tamém, nem tudo é ruim, né? Sempre tem um lado positivo tamém. Aprendi a tê gosto pela leitura.

(UISM, relato de André, 16a)

Observe-se que em (92), André afirma não ter aprendido nada na Unidade de Internação, a não ser o gosto pela leitura. Há, em sua fala, uma sequência argumentativa de um fator negativo seguido de um positivo, no que se refere aprendizado na instituição. Para o socioeducando, aprender significa procurar mudar, refletir e entender o porquê de sua apreensão. Utiliza o processo material procurar (fazer e acontecer) para frisar que deve ocorrer uma mudança interna no fluxo dos eventos de sua vida, seja para refletir sobre o porquê de estar apreendido e as consequências desse ato, seja para não receber o tratamento que recebe dentro da instituição. Na organização sequencial de sua fala, há uma escala argumentativa $(\mathrm{KOCH}, 2016$, p.62) que permite orientar, com o uso do operador argumentativo também, a existência de um fator positivo encontrado, pelo adolescente, na Unidade de Internação, como se pode observar nos enunciados ah, tamém, nem tudo é ruim, né? Sempre tem um lado positivo tamém. Aprendi a tê gosto pela leitura. Para o adolescente, o projeto de leitura, que propiciou seu gosto pela leitura, vem como o único aprendizado positivo oferecido pela instituição.

A seguir, apresento outro fragmento, referente ao aprendizado na UISM, de relato de uma socioeducanda. A sequência argumentativa, porém, encontra-se inversa: primeiro, a questão positiva apontada pela adolescente. Depois, a negativa. Vejamos.

(93) Positivo é que você sai daqui mais maduro! Você sai dando mais valor nas coisas pequenas lá de fora. Porque eu tenho minha mãe, eu tenho minha família, eu tenho todo mundo! E agora, eu conheci meninas aqui dentro que, tipo, são abandonadas! E eu já aprendi a dar valor no que eu tenho! Minha mãe nunca faltou uma visita. Tem menina aqui que uma vez na vida vê a mãe, quando a mãe vem! Tem menina que a mãe sumiu. A menina mesmo que eu puxo, ela ficou sabeno, a mãe dela sumiu, tá nem aí! E isso é que eu tenho valor presente, é valor lá fora. Cê aprende é isso! Dá mais valor! Entendeu? O negativo é porque isso aqui mexe muito com a sua cabeça! Cê tá preso num, é um quadrado aquele quarto! Ce vai, cê é vinte e quatro horas quase presa. É da escola pro quarto, entendeu? E tamém, que tem agentes, que... Num, num entende que... Conversando você vai aprender mais.

(UISM, relato de Felicidade, 17a)

De acordo com o excerto (93), o aprendizado de Felicidade ocorre em termos de amadurecimento de suas relações familiares. A adolescente faz um comparativo entre ela e as 
meninas abandonadas e desamparadas pela família. Ao valorizar sua família, usa a expressão dar valor em sai dando mais valor, já aprendi a dar valor, dá mais valor. E isso é que eu tenho valor presente, é valor lá fora. A adolescente, por um lado, destaca como aprendizado positivo a capcidade de perceber a importância das visitas e da presença da mãe, nos dias estipulados. Por outro lado, como o ponto negativo, evidencia o que sente por estar apreendida, como se pode observar nos segmentos oracionais: o negativo é porque isso aqui mexe muito com a sua cabeça! Cê tá preso num, é um quadrado aquele quarto. Cabe ressaltar a observação feita pela socioeducanda em relação à situação de reclusão no enunciado ce vai, cê é vinte e quatro horas quase presa. É da escola pro quarto, entendeu? De acordo com esses segmentos, pode-se observar que não há cursos profissionalizantes, atividades físicas ou práticas que envolvam uma reeducação social. Essa escassez de atividades, portanto, ocasiona a ociosidade dos socioeducandos. Além dessa questão, a adolescente relata a necessidade de conversa e de diálogo entre socioeducandos e agentes de polícia. Nesse viés, Felicidade utiliza o processo mental cognitivo entender para inferir que falta entendimento por parte dos agentes concernente às relações interpessoais. Conforme a adolescente, os agentes de polícia não entendem que, com diálogo, aprende-se mais do que com o uso da força ou com uma determinada forma de coerção, como se pode observar no enunciado Num, num entende que... Conversando você vai aprender mais.

De modo diferente das vozes destacadas nos excertos (90), (91) e (92), os estudantes do CMB enxergam a aprendizagem sob uma outra perspectiva. Vejamos.

(94) Aí, o Colégio, ele proporciona isso, ele traz é:::., uma organização, humm, a questão tanto de respeito quanto de limites... Que fazem, tipo... É:::: Com que vão criando o caráter do aluno pra ele ser um aluno mais responsável, pra quando ele deixar de ser aluno, passar a ser um funcionário, ele possa ser um funcionário é, educado, na questão de ter respeito, chamar de, é, comunicação com as outras pessoas. Ele traz, também, um suporte pra, tanto escolar quanto, as matérias que são bem desenvolvidas pelos professores, o que não deixa você precisar... Não que você não tenha que se esforçar tanto! Mais, traz um preparo melhor, faz com que você consiga ter uma base melhor pra o ensino superior! Aí, o Colégio, ele ajuda em todas essas questões, tanto o relacionamento... É, entre as pessoas quanto no ambiente de trabalho com o trabalho em si. Você tem... Cê tem essa relação!

(CMB, relato de Daniel, 15a)

No excerto (94), Daniel relaciona o CMB a questões referentes à organização, respeito e limites. Ele outorga a esses fatores requisitos essenciais para o desenvolvimento do caráter do aluno. O estudante qualifica a escola como base de educação tanto na formação do ensino, 
como na vida futura. Ele utiliza, na maior parte de sua fala, processos materiais que apontam para o fazer, tais como, trazer, proporcionar e criar, e também, para uma mudança no fluxo dos eventos, como é o caso do passar em passar a ser um funcionário. Isso parece evidenciar que o aprendizado é positivo e é concreto e efetivo, já que, para o adolescente, o Colégio orienta o aluno em termos pedagógicos e de convívio social. A visão de Daniel vislumbra o futuro, quando menciona o a relação do $\mathrm{CMB}$ com o ensino superior em faz com que você consiga ter uma base melhor pra o ensino superior e ao citar uma relação respeitosa em seu ambiente de trabalho. A seguir, será apresentado outro fragmento de relato de um aluno do CMB.

(95) O Colégio Militar tem professores ótimos, e, principalmente agora, agora, no segundo ano eu percebi que todos os professores falam: "vocês têm, os profes, aqui, né?", eles falam: "vocês têm a mim pra correr atrás! Então, sempre que puder, mande perguntas, pesquise, faça! A gente vai sempre dar apoio!” Isso sempre, o Colégio Militar sempre deu esse apoio, então, eu acho que se você consegue estudar pro Colégio Militar e ser um bom aluno aqui, acho que você vai conseguir ser um bom aluno fora! Claro que, assim como tem cursos pra EsPCEx ((Escola Preparatória de Cadetes do Exército)) à tarde, aqui, eu acho que o Colégio também dá muito suporte, não suporte total que eles poderiam fornecer ((mais aulas)), claro que também tem carga horária de professor, mais, sem dúvida, o Colégio Militar dá muito suporte, não tenho dúvidas disso, que se alguém quiser se dar bem aqui, tem chances! E grandes!

(CMB, relato de Samuel, 16a)

Samuel, ao responder a pergunta referente ao aprendizado na instituição, inicia o enunciado, no excerto (95), dando destaque ao Colégio Militar e codifica um significado de posse, ao fazer uso do Processo Relacional Possessivo ter em $O$ Colégio Militar tem professores ótimos. Isso, porque o estudante busca relacionar o Colégio aos professores. Dessa forma, o aprendizado, para Samuel, apoia-se no qualificativo dos professores e na percepção de que ele, como aluno, obtém do que é transmitido pelo corpo docente. Observese que ele reproduz vozes externas, com o processo verbal falar, que, nesse caso, são as vozes dos professores em todos os professores falam: vocês têm, os profes, aqui, né?, eles falam: vocês têm a mim pra correr atrás! Então, sempre que puder, mande perguntas, pesquise, faça! A gente vai sempre dar apoio! Cabe destacar, também, o uso do processo material dar (do fazer e acontecer) em o Colégio Militar sempre deu esse apoio e o Colégio Militar dá muito suporte. Nesses casos, materializa-se, no discurso do estudante, a credibilidade no ensino oferecido pelo CMB e na oportunidade de aprendizado que o Colégio busca oferecer aos estudantes. 
Eis, então, o antagonismo existente do aprendizado nas duas instituições: os estudantes beneficiados por um processo de educação de qualidade, no CMB, consideram a instituição como um veículo para a inserção de valores e conhecimento e como um agente que os auxilia nos prognósticos do futuro que almejam. Já os socioeducandos declaram que a instituição não contribui, de forma eficaz, para um aprendizado específico, seja o educacional, seja o profissional. Observa-se que o aprendizado positivo, na Unidade de Internação, deveria ocorrer de maneira eficiente e produtiva e estar voltado para a mudança de comportamento e de visão de mundo dos socioeducandos a fim de que houvesse o desenvolvimento integral para o convívio desses adolescentes em sociedade. Entretanto, como exposto pelos próprios socioeducandos da UISM, não há medidas socioeducativas que evolvam educação de qualidade, tampouco atividades profissionalizantes que abranjam todos os adolescentes. Como discutido em Carvalho (2011),

quando um indivíduo produz algo, tanto intelectualmente quanto manualmente, tende-se a aumentar sua autoestima, pois ele ocupa a mente e executa algum tipo de atividade que o faz pensar e produzir algo para si e também para outras pessoas. (CARVALHO, 2011, p. 93)

Falando-se especificamente dos adolescentes que estão em situação de reclusão, é necessário que o Estado invista em ações socioeducativas eficazes pedagógicas e profissionalizantes, para que esses adolescentes ocupem suas mentes com estudo, leitura, atividades físicas e manuais, o que constitui uma forma de impedir constante ociosidade, característica observada nas falas dos socioeducandos, pois, conforme bem lembra Passold (1984, p. 57), “a função social, condição instrumental do Estado, tem compromisso com o bem comum e com a dignidade humana". Pondera-se, aqui, que sejam cultivados, nos socioeducandos, os valores para o desenvolvimento "físico, mental, moral, espiritual e social", como assegura o art. $3^{\circ}$ do ECA, para que lhes seja despertada uma nova mentalidade e, consequentemente, sejam realizadas, de forma efetiva, a socioeducação, a reeducação e a reintegração social desses adolescentes, no intuito de que não se tornem reincidentes nos delitos e nas Unidades de Internação e, posteriormente, nas penitenciárias.

O aprendizado, no presente, estabelece um vínculo com o futuro. Se a instituição não propicia atividades que acarretem uma prospecção de futuro favorável e promissor, perguntase: qual o benefício da existência dessa instituição? 


\subsubsection{Perspectivas do Futuro}

A última categoria encontrada, nos relatos dos adolescentes das duas instituições, foi a de Futuro. Pondera Bakhtin (1993) que o futuro pertence a uma realidade incerta e vaga. Contudo, para o autor (BAKHTIN, 1993, p. 264), "o presente e, sobretudo, o passado enriquecem-se à custa do futuro". Dessa forma, o valor enriquecedor dos relatos concerne ao vir-a-ser futuro, pois representa os objetivos, os ideais, as esperanças, as expectativas e os desejos de mudança que, nesse caso, envolvem os adolescentes dos dois contextos abordados. Esse futuro ou futuridade, apesar de seu sentido rarefeito e incerto, constrói projeções, aqui, que permeiam duas perspectivas semelhantes dos adolescentes do CMB e da UISM: estudar e trabalhar. ${ }^{35}$ Vejamos.

(96) Voltar a estudar, ser alguém na minha vida e não ser isso que eu escolhi pra minha vida ((traficante de entorpecentes)).

(UISM, relato de Nazaré, 16a)

Para Nazaré, conforme relatado no excerto (96), ter entrado no mundo do crime foi uma escolha errada em sua vida. Há, em sua fala, uma tentativa de se regenerar, talvez como uma alternativa de uma nova representação de uma nova identidade.

Garapon (1999, p. 122-123) lembra que a "delinquência passa a ser, às vezes de maneira inédita, a busca da identidade, fato novo e mais desconcertante”. O maior problema, segundo o autor, não é somente o controle social, mas, sim, a exclusão; não está tanto em não saber impor normas, mas aprender a viver sem elas; não está na liberação, mas na vinculação; além disso, não é resistir à pressão social, porém suportar a angústia do vazio criado pela despressurização moderna. Esse fato é observado quando a adolescente relata, no segmento oracional seguinte, o desejo de mudança em ser alguém na minha vida e não ser isso que eu escolhi pra minha vida. O processo comportamental escolher aponta para a opção de ingresso na criminalidade (no mundo físico do agir), materializando, em seu relato, um traço de rejeição que marca o seu mundo interior perante as práticas de ações delituosas.

\footnotetext{
${ }^{35}$ Conforme Silva (1997, p. 55), a expressão da futuridade, termo utilizado por Binnick (1971, p.120), não se restringe às formas do tempo verbal futuro. Além do presente futuro (praesens pro futuro, do latim), as línguas românicas possuem formas perifrásticas que também denotam futuridade. Pode deixar, eu faço o serviço amanhã (presente futuro), eu vou fazer o serviço, (ir + infinitivo), estou para fazer o serviço (estar para + infinitivo) são formas futurizadas, visto que se utilizam do presente do indicativo para expressar futuridade.
} 
Já o pronome demonstrativo isso aparece como um Atributo depreciativo em relação aos atos delituosos cometidos por ela nessa opção de vida. O relato de Nazaré transparece a conscientização da adolescente de que o estudo é o caminho para a mudança de sua atual situação de forma que vislumbra uma realidade diferente da sua atual.

Abaixo, será apresentado mais um relato de socioeducanda que vislumbra, no estudo e na formação escolar, uma forma de mudança para sua vida.

(97) Sair daqui... Dependendo, né?, com fé em Deus, eu creio que até dezembro eu já fui embora, mas se eu não tiver ido embora até dezembro e eu chegar a ficar de maior aqui dentro... Quando eu for embora em julho, que completo os três anos, eu vou fazer um EJA, mas eu vou fazer um EJA e passar pra faculdade ((Maria Madalena cursava o $7^{\circ}$ ano)). Fazer faculdade de Direito, passar a advogada e vou embora pra São Paulo. São Paulo eu vou pra Minas, lá pra Tuitaba. Não! Eu vou embora daqui de Brasília! Que Brasília, essa aqui é a cidade do crime e já deu pra mim tudo que tinha que dá! Num tem, pra falar a verdade, eu num conheço um adolescente que nasce no DF... Ou vira pessoa do bem... Ou vira traficante! Ou morre ou vira pessoas usuário de drogas, não tem uma pessoa que eu não conheço, porque em Ceilândia, o DF é a cidade do crime! É impossível, aqui, o DF! É impossível a pessoa tá no DF, só quando a pessoa, se a pessoa num tivé uma mentalidade muito forte ali, pra decidi o que ela qué pra vida dela, ela se afunda na vida do crime, mas se ela tiver força, ela num entra.

(UISM, relato de Maria Madalena, 17a)

No excerto (97), Maria Madalena vê no estudo um caminho para a construção de uma nova vida. A adolescente projeta seu futuro ao usar os processos materiais abstratos vou fazer e passar nos enunciados eu vou fazer um EJA e passar pra faculdade. Há, nela, uma grande vontade de conseguir ter uma formação profissional e se mudar de Brasília. A socioeducanda faz referência ao Distrito Federal como a cidade do crime e enumera quatro situações enfrentadas na capital federal: ou vira pessoa do bem, ou vira traficante, ou morre ou vira pessoas usuário de drogas. A respeito da inserção na criminalidade, Maria Madalena afirma que se a pessoa num tivé uma mentalidade muito forte ali, pra decidi o que ela qué pra vida dela, ela se afunda na vida do crime, mas se ela tiver força, ela num entra. A força, nesse caso, é o Atributo essencial no enunciado. Foi, justamente, o que a adolescente em conflito com a lei não conseguiu encontrar quando saiu da Unidade de Internação.

Faz-se necessário tecer um breve comentário acerca da atual situação da adolescente Maria Madalena. Obtive informações que a adolescente havia saído da UISM, uma vez que, anteriormente, havia cumprido a medida socioeducativa. Entretanto, quando saiu da Unidade de Internação, retornou à prática do crime, o que acarretou sua prisão na penitenciária de 
mulheres jovens e adultas de Brasília (Colmeia). ${ }^{36}$ Assim, tal reincidência implicou uma mudança de categoria (em termos jurídicos) de socioeducanda para presidiária. Esse caso, além de muitos outros, só faz corroborar a ideia de que o sistema de internação como está não recupera, não educa e não socializa quase ninguém. Dessa forma, salienta-se que, ao devolver à sociedade um socioeducando que ficou anos trancado em uma cela, de forma ociosa, sem ter acesso a um ensino contínuo, sem fazer um curso profissionalizante, sem ter uma ocupação para, quando sair da internação, tentar mudar a sua realidade, pode-se esperar que ele volte a cometer infrações, delitos e crimes, como foi o caso de Maria Madalena que, apesar da vontade de mudar o curso de sua vida, não teve condições para a tão almejada transformação.

Algumas reflexões podem ser feitas a respeito da situação de liberdade de Maria Madalena: como não entrar novamente no mundo do crime, depois de ficar três anos apreendida, sem ter uma família estruturada, ou mesmo, ao menos uma família, para ajudá-la a concretizar os planos feitos quando estava apreendida? Como não retornar à criminalidade se não são oferecidas condições favoráveis de educação e profissionalização para a ressocialização e reeducação da socioeducanda? O que fazer com essa adolescente e tantos outros que saem da internação e voltam a viver de maneira precária, sem estudo, sem trabalho, sem estrutura e viciados em drogas? Por mais que existam alguns profissionais engajados que trabalhem em favor da reeducação do socioeducando nas Unidades de Internação, isso não é suficiente para que não ocorra a reincidência, porque o que parece faltar é um empenho maior do Estado, bem como políticas públicas eficazes para diminuir a vulnerabilidade pessoal e a vulnerabilidade social.

No fragmento abaixo, encontra-se mais um acaso de relato de um socioeducando da Unidade de Internação de Santa Maria.

(98) Hoje eu tenho meus objetivos de vida! Que é:::: Terminá meus estudo. Fazê a:::: A prova do Enem. Consigui uma bolsa, nem que seja cinquenta por cento, pra mim fazê minha faculdade de Direitos. Ajudá minha mãe ((catadora de lixo)), tirá minha mãe daquela cidade ((Cidade satélite Estrutural)). Dá uma vida melhor pra minha família! E construí uma família tamém! Tê um filho. Arranjá uma mulhé digna, que eu tenho a certeza que se acontecê algo comigo que ela vai tá cuidano do meu filho... Num vai larga, num vai deixá largado.

(UISM, relato de Tomé, 17a)

\footnotetext{
${ }^{36}$ Presídio Feminino do Distrito Federal (Popularmente conhecido como Colmeia), está situado no Setor de Chácaras da região administrativa do Gama, no Distrito Federal. Destina-se ao recolhimento de mulheres, sentenciadas ao cumprimento de pena privativa de liberdade, nos regimes Semi-aberto e fechado, bem como de presas provisórias, que aguardam julgamento pelo Poder Judiciário.
} 
No excerto (98), o adolescente enfatiza sua fala, ao fazer uso do Processo Relacional Possessivo Atributivo ter na forma tenho em Hoje eu tenho meus objetivos de vida, o que evidencia uma relação semântica da circunstância de tempo hoje com o Atributo meus objetivos de vida. Essa relação parece revelar uma nova visão de mundo do socioeducando ao introduzir a sequência de processos materiais (do fazer e acontecer) terminar, fazer, conseguir, fazer, ajudar, tirar, dar, construir, arranjar, os quais permitem apontar um encadeamento de projeções de ações almejadas pelo adolescente. Pode-se observar que meus estudo aparecem como Meta e parecem ser, para o socioeducando, o campo de possibilidade para sair da vida delituosa em que se encontrava. Esses estudos, segundo o adolescente, propiciar-lhe-ão a entrada na faculdade de Direito por meio do Enem - Exame Nacional do Ensino Médio. Ressalte-se que Tomé se vê, na construção de seu discurso, como uma pessoa que irá ajudar sua família a sair do estado de vulnerabilidade social em que ela se encontra. A ideia da concepção de uma família com mulher e filho também permeia a projeção de expectativa futura do adolescente. Vale destacar que a figura da mulher idealizada e almejada por ele é a de alguém com valores morais, ou seja, uma mulhé digna e responsável, como pode ser visto no enunciado ela vai tá cuidano do meu filho... Num vai larga, num vai deixá largado. Essa mulher deverá cuidar dele e do filho que deseja ter e deverá ser uma pessoa detentora de um comportamento socialmente esperado, sem desviar das regras sociais no que se refere às questões familiares e morais. No fragmento a seguir, será apresentada uma outra realidade observada, com o relato de um aluno do CMB.

(99) Pra eu conseguir, primeiramente, o meu futuro é:::: ter uma profissão estável, ter uma família estável. Hã::::, viver com conforto, bem na sociedade e aquilo que aprendo na escola eu posso não pôr em prática tipo, no futuro, mas elas são importantes, primeiramente, pra eu conseguir um emprego, né? ((o estudante referiu-se a alguns conteúdos estudados no colégio nas áreas de ciências biológicas, linguagens e códigos e exatas)), já que a gente vive nesse, nessa.... na sociedade que eu preciso passar no vestibular! Ah, eu quero fazer exatas, mas eu preciso também saber humanas! Não que só pro vestibular.

(CMB, relato de Paulo, 16a)

No excerto (99), Paulo prioriza duas características para seu futuro indicadas pelo Processo Relacional Possessivo ter: a profissional e a familiar, evidenciadas no enunciado ter uma profissão estável, ter uma família estável. ${ }^{37}$ A família estável, aqui, aparece como um

\footnotetext{
${ }^{37}$ Conforme Halliday e Matthiessen (2004), as orações relacionais possessivas incluem a possessão de partes do corpo, outras relações parte-todo, conteúdo e envolvimento, bem como abstrações.
} 
dos requisitos para um futuro promissor e bem sucedido, o que não pôde ser observado nos fragmentos (96) e (97) acima. O estudante salienta que a fase de aprendizado no Colégio é uma etapa importante da vida para se obter o futuro almejado, pois, para alcançar o que se ambiciona, é preciso fazer o vestibular e ver conteúdos que, segundo ele, só terão utilidade no momento da prova. $\mathrm{O}$ adolescente, de maneira peculiar, evidencia, com o uso da circunstância de modo, que deseja viver com conforto, bem como ter uma profissão e uma família.

No excerto abaixo, a estudante almeja ter uma profissão. Vejamos a seguir.

(100) O meu sonho é entrar na carreira militar como oficial, pra Espcex, que vai abrir esse ano, inclusive, as provas, pela primeira vez na história do Brasil, é o meu maior sonho ingressar nessa instituição militar como oficial!

(CMB, relato de Dalila, 16a)

De acordo com o excerto (100) em destaque, Dalila já tem definido o que fará no futuro. A estudante vê, na carreira militar, o campo profissional a ser conquistado. Os Processos Relacionais em o meu sonho é entrar na carreira militar como oficial e é o meu maior sonho ingressar nessa instituição militar como oficial permitem destacar unidades de informação de natureza identificativa, como a entrada e o ingresso, além de circunstâncias de localização específicas: na carreira militar e nessa instituição militar, que mostram, de forma marcada, o objetivo de vida almejado pela adolescente.

Faz-se necessário lembrar que, geralmente, quem segue a carreira militar tem um comprometimento com o país e tem como um dos valores primordiais o patriotismo, que, segundo o Exército Brasileiro, é o mesmo que "amar à pátria" 38 , assim como a permanência no Brasil, ou, se sair do país para cumprir alguma missão, o retorno, como parece ser a intenção da adolescente. Entretanto, há situações em que o intuito é sair do país, ou "na pior das hipóteses, ficar aqui" como relata, abaixo, o estudante do CMB.

(101) Na melhor das hipóteses, eu me imagino um pesquisador... De uma universidade no Reino Unido. Ou no Canadá, ou nos Estados Unidos ou no Japão! Pesquisador, e eu espero contribuir grandiosamente pra comunidade científica! Prêmio Nobel, essas coisas, na melhor das hipóteses mesmo! Mas, assim, se eu já tiver contribuindo grandemente pra comunidade científica, eu já tô feliz! E na pior das hipóteses... ficar aqui em Brasil, no Brasil mesmo... Né? Num sei o quê que eu vou fazer, porque biotecnologia... É...! Trabalhando numa empresa normal aqui. Mas eu quero mais ser pesquisador, mesmo, trabalhar.

(CMB, relato de Moisés, 16a)

\footnotetext{
${ }^{38}$ Informação retirada de <http//:www.eb.mil.br>
} 
No excerto (101), Moisés traça, como objetivo, uma carreira de pesquisador em alguma universidade fora do país. O adolescente, em sua fala, faz uso de expressões antônimas, na melhor das hipóteses e na pior das hipóteses, que parecem demonstrar a insatisfação de ter de estudar e trabalhar no Brasil. Para reiterar a vontade de participar do estudo de pesquisa científica, utiliza o processo material contribuir seguido de circunstâncias que indicam, de forma exacerbada, o modo de contribuição, como pesquisador, para a comunidade científica, quais sejam, grandiosamente e grandemente. Pode-se notar essa assertiva em: e eu espero contribuir grandiosamente pra comunidade científica e mas, assim, se eu já tiver contribuindo grandemente pra comunidade científica, eu já tô feliz! O que mais cabe ressaltar é o grande desejo do estudante de abandonar o Brasil, como se tivesse uma aversão em ficar no próprio país.

Quanto às perspectivas de futuro dos adolescentes do CMB e da UISM, parece haver a vontade, dos adolescentes de ambos os contextos, de estudar e, no futuro, trabalhar. Porém, pode-se afirmar que as oportunidades, nos dois contextos, são diferenciadas. Resulta que, para os socioeducandos, há uma possibilidade menor de concretização dos planos almejados por eles. Como observado no caso de Maria Madalena, por falta de um devido resgate de sua identidade enfraquecida, bem como de um tratamento voltado para a mudança de atitudes e pensamento, socioeducandos poderão ser considerados reincidentes, nos delitos, infrações e crime de acordo com o sistema legal. Quanto às identidades, vale citar Bauman (2005), uma vez que

tornamo-nos conscientes de que o 'pertencimento' e a 'identidade' não têm a solidez de uma rocha, não são garantidos para toda vida, são bastante negociáveis e revogáveis, e de que as decisões que o próprio indivíduo toma, os caminhos que percorre, a maneira como age - e a determinação de se manter firme a tudo isso - são fatores cruciais tanto para o 'pertencimento' quanto para a 'identidade'. (BAUMAN, 2005, p. 19)

Portanto, se houvesse um maior interesse de resgatar as identidades de adolescentes que são, muitas vezes, pessoas invisíveis para a sociedade, com ações e políticas públicas eficazes, poder-se-ia minimizar a reincidência de socioeducandos nas Unidades de Internação e, consequentemente, diminuir a criminalidade e a violência que assolam o país. Por outro lado, grande parte dos estudantes beneficiados pelo processo de educação, no CMB, têm prospecções de futuro e se preocupam com o estudo e com o trabalho e, em sua maioria, conseguem concretizar seus projetos, seja no Brasil, seja em outros países. 
Ainda com base em aspectos inerentes à voz dos adolescentes, apresento, a seguir, uma análise envolvendo o sistema de avaliatividade de acordo com o proposto por Martin e Rose (2003).

\subsection{A REDUÇÃo dA MAIORIDAdE PENAL NA VOZ AVALIATIVA dOS ADOLESCENTES}

O Sistema de Avaliatividade no discurso dos adolescentes é o foco da análise nesta subseção. Isso, porque, conforme Martin e Rose (2007), esse sistema é um dos principais recursos semântico-discursivos para a realização de significados interpessoais em relação à avaliação de coisas, comportamento das pessoas e seus próprios sentimentos, bem como para negociar emoções, julgamentos e avaliações (MARTIN, 2000). Nessa esteira, Thompson (2004, p. 65) assegura que a análise de um texto envolvendo seus significados interpessoais deve considerar os itens avaliativos. Sendo assim, a linguagem da avaliação compreende diversas circunstâncias que compõem a experiência do falante. Conforme Vian Jr. (2009), a avaliatividade

está relacionada ao sistema e cada uma das escolhas avaliativas feitas pelo usuário, permeadas por outros discursos, por suas crenças, seus julgamentos, suas experiências de mundo, afeto e diversos outros elementos contextuais e individuais que serão instanciadas e realizadas no texto léxicogramaticalmente. (VIAN JR., 2009, p. 126)

Existe, portanto, uma relação intrínseca entre o contexto, a linguagem, as escolhas linguísticas e a avaliação, visto que a avaliatividade depende do contexto, da relação entre os usuários, das diferenças culturais e sociais, pois "um item lexical pode assumir um significado avaliativo em um contexto e em outro não" (VIAN JR., 2009, p. 126). Ademais, o Sistema de Avaliatividade inclui e expande o Sistema de Modalidade situado na área dos significados interpessoais que envolvem a negociação dentro das relações, também a expressão de opiniões e avaliações. Esse sistema concebe duas formas de realização de avaliação: explícita ou escrita, que é a mais comum e ocorre por meio de palavras com traços avaliativos, sobretudo com os adjetivos; e implícita, ou evocada, que ocorre por meio de orações que sugerem uma reação avaliativa nos ouvintes/leitores, mesmo que não sejam encontrados itens lexicais claramente expressos (MARTIN; WHITE, 2005).

Nesse viés, houve a necessidade de analisar, por meio do Sistema de Avaliatividade, a voz dos socioeducandos da UISM e dos alunos do CMB sobre o tema "redução da maioridade penal", pois, ao ler as produções textuais e ouvir as entrevistas, pude observar que a avaliação 
estava inserida nos textos escritos e orais, na medida em que os construtos semânticodiscursivos foram utilizados pelos adolescentes para avaliarem algo ao expressarem sentimentos e emoções, bem como tecerem julgamentos referentes ao tema. À vista disso, serão apresentados, por um lado, fragmentos de textos produzidos por socioeducandos da UISM, elaborados como atividade prática, concernentes a aulas de português, ministradas por mim na Unidade de Internação. Por outro, excertos de entrevistas orais obtidas junto a estudantes do $\mathrm{CMB}$, que versaram sobre o mesmo tema.

Faz-se necessário lembrar que Fairclough (2003) emprega o termo "texto" de forma estendida para a dimensão semiótica de eventos sociais. Para o autor, são textos, tanto os documentos escritos e sítios de governo, como também as entrevistas e reuniões em organizações governamentais ou comerciais. Dessa forma, o termo "texto" carrega, de fato, um sentido ambíguo, porque raramente não é associado a textos escritos. Entretanto, para o autor, é difícil encontrar outro termo para substituí-lo.

Ressalte-se que os dados observados me conduziram a buscar, em termos analíticos, uma categorização envolvendo o sistema interpessoal da linguagem voltada para avaliações e atitudes dos adolescentes em relação aos textos escritos e às entrevistas. Para tanto, aos alunos do CMB, perguntei-lhes, por meio de entrevistas orais, se eles eram contra ou a favor à ideia de redução da maioridade penal. Já aos socioeducandos da UISM, solicitei-lhes que fizessem uma produção textual a respeito desse mesmo tema. A seguir, será apresentada a proposta de redação elaborada aos socioeducandos.

Proposta de produção de texto para os socioeducandos da UISM

\section{Redução da Maioridade Penal}

Prezado adolescente, estou fazendo uma pesquisa sobre "redução da maioridade penal". Esse estudo é para poder ouvir "as vozes" de vocês, meninos e meninas que estão cumprindo medidas socioeducativas nas Unidades de Internação.

Peço, então, que você faça um texto comparando a proposta da redução da maioridade penal de 18 para 16 anos com sua experiência de vida. Gostaria, também, que você escrevesse se concorda ou não com essa mudança e justificasse sua resposta. Além disso, comente os pontos negativos e/ou os positivos dessa proposta.

Muito obrigada! 
A digitação dos textos escritos encontra-se na íntegra, bem como a fala original dos adolescentes entrevistados, ou seja, sem correções gramaticais.

Cabe, aqui, fazer um breve esclarecimento a respeito da redução da maioridade penal. Esse tema tem sido motivo de uma série de debates com intensas discussões, tanto nas diversas camadas da sociedade brasileira como um todo, quanto no meio jurídico e no campo político de maneiras específicas. Tais discussões tornam-se cada vez mais exasperadas, sobretudo no momento atual em que culmina a polêmica diante da proposta de redução da maioridade, dentro do Código Penal brasileiro, de 18 (dezoito) anos para 16 (dezesseis) anos de idade. ${ }^{39}$

A maioridade penal no Brasil se dá aos dezoito anos, segundo o artigo no 228 da Constituição Federal de 1988, que reza serem penalmente inimputáveis os menores de dezoito anos, sujeitos às normas da legislação especial. O artigo da Constituição Federal - CF, em seu parágrafo $\mathrm{n}^{\circ} 228$, é reforçado pelo artigo $\mathrm{n}^{\circ} 27$ do Código Penal, mediante o qual os menores de 18 (dezoito) anos são penalmente inimputáveis, ficando sujeitos às normas estabelecidas na legislação especial, o que se reflete no artigo no 104 do Estatuto da Criança e do Adolescente - ECA, enquanto lei específica que trata do tema (Lei $n^{\circ}$ 8.069/90). De acordo com esses dispositivos legais, são penalmente inimputáveis os menores de dezoito anos, sujeitos às medidas previstas na Lei Maior. Faz-se necessário observar que, para os efeitos dessas leis que se complementam, deve-se considerar a idade do adolescente à data do ato infracional. Observe-se ainda, que, nesse sentido, a CF de 1988 recorre, por meio do critério etário, à presunção de inimputabilidade.

Com base nos elementos do Sistema de Avaliatividade, especificamente no subsistema de Atitude, são observados excertos da produção textual dos socioeducandos da UISM e das entrevistas feitas aos estudantes do CMB sobre suas opiniões a respeito da redução da maioridade penal.

(102) Na minha opinião eu não concordo. Porque nois vamos ter que perde um pouco da nossa adolecencia e vamos ter que criar mais responsabilidade pelos nossos atos. E vai ter que ter mais oportunidades de emprego para nois Adolecentes porque não é só prende que vai nos resocializar é mais oportunidade que vai nos ajuda a não cometer atos infracionais.

(UISM, produção textual de Manuel, 16a)

\footnotetext{
${ }^{39}$ A discussão dessa pauta encontra-se no Senado, que ainda precisa decidir se aprova a proposta de emenda à Constituição (PEC).
} 
No excerto (102), Manuel sinaliza o afeto negativo ao discordar com a redução da maioridade penal de 18 para 16 anos pelo motivo de perder o período da adolescência e adquirir, de maneira forçada, uma responsabilidade não inerente a essa fase, como se pode observar no enunciado nois vamos ter que perde um pouco da nossa adolecencia e vamos ter que criar mais responsabilidade pelos nossos atos. Além disso, o afeto negativo, ligado à insatisfação, encontra-se submerso no momento em que o socioeducando antevê a falta de oportunidade futura de emprego.

Observa-se, também, o subsistema de Gradação no subtipo Intensificação por Repetição do processo ter nos enunciados porque nois vamos ter que perde um pouco da nossa adolecencia e vamos ter que criar mais responsabilidade pelos nossos atos. E vai ter que ter mais oportunidades de emprego para nois Adolecentes. O socioeducando parece reforçar que, com a redução da maioridade penal, os adolescentes terão que crescer e se tornarem adultos, de certa forma, à força. Entretanto, esse crescimento terá de ser paralelo às oportunidades que se apresentarem no decorrer de sua vida precocemente adulta.

Em seguida, no enunciado porque não é só prende que vai nos resocializar é mais oportunidade que vai nos ajuda a não cometer atos infracionais, o adolescente manifesta, em seu texto escrito, o julgamento de estima social, na categoria capacidade, devido à inoperância prisional diante da expectativa da reincidência de atos infracionais. Cabe destacar que, pela própria proposição de se produzir um texto escrito opinando ser contra ou a favor da redução da maioridade penal, o adolescente expôs seu pensamento em relação ao tema, o que o induziu a utilizar o recurso linguístico de metáfora de modalidade, assim nomeada por Halliday (1994, p. 354), por estar gramaticalmente em uma oração separada e completa, como é o caso da expressão na minha opinião, que explicita a autoria ou a fonte da modalidade, uma vez que o pronome é evidenciado. Observa-se, dessa forma, que o socioeducando é contrário à redução da maioridade penal.

(103) Não concordo com a redução da maioridade penal. Eu sou um caso em que a ressocialização deu certo, quando tinha 16 anos não pensava em mudar, depois que vim presa, comecei a estudar, conheci um outro mundo e vi que tem como eu ser alguem na vida sem estar na vida do crime.

(UISM, produção textual de Maria, 17a)

No excerto (103), Maria topicaliza seu texto com a polaridade que, conforme Halliday (1989, p. 88), é a “escolha entre positivo e negativo". Note-se que no enunciado não concordo 
com a redução da maioridade penal, a adolescente faz uso da polaridade negativa, com o emprego discursivo-textual não, em consonância com o processo mental desiderativo concordar em não concordo como forma de estratégia, para posteriormente, argumentar que ela foi um caso de êxito de reeducação social. Em eu sou um caso em que a ressocialização deu certo, observe-se que o uso do Processo Relacional ser em sou, como elemento discursivo, expressa a relação da característica (Token) eu e do valor (Value) um caso em que a ressocialização deu certo. $\mathrm{O}$ afeto positivo e segurança aparecem no enunciado eu sou um caso em que a ressocialização deu certo, pois a adolescente apresenta o conceito de resultado de ressocialização assertivo.

Além disso, no enunciado conheci um outro mundo e vi que tem como eu ser alguem na vida sem estar na vida do crime, percebe-se o julgamento em estima social na categoria capacidade, pois ela conseguiu ser alguem na vida sem estar na vida do crime. Os processos mentais cognitivos pensar e conhecer em quando tinha 16 anos não pensava em mudar, conheci um outro mundo remetem a um estado consciente, bem como a uma nova visão de mundo e, consequentemente, a um novo contexto de situação do Experienciador, nesse caso, denominado senser. ${ }^{40}$

(104) Ao inves de jovens e adolescente, nós teremos crianças cada veiz menores nas unidades de internação, jovens de 16 e 17 anos prezos nas penitenciarias com adultos de 30, 40, 50 anos, a superlotação dos presídios, o sofrimento das mães que perderão os filhos cada veis mais cedo, e a sossessiedade que no futuro um dia se arrependera por ter sido a favor de uma grande tragédia.

(UISM, produção textual de João, 17a)

No excerto (104), emerge o sentimento de infelicidade quando João alude para o fato da inserção de jovens nas penitenciárias de adultos e para sofrimento de mães que perderão seus filhos precocemente. O julgamento está expresso no enunciado a sossessiedade que no futuro um dia se arrependera por ter sido a favor de uma grande tragédia. O processo arrepender-se mostra-se como um elemento de estima social e projeta a causa do arrependimento no enunciado por ter sido a favor de uma grande tragédia. Além disso, cabe destacar que, para o socioeducando, a redução da maioridade penal aparece em forma metafórica como uma grande tragédia.

\footnotetext{
${ }^{40}$ Segundo Halliday (1994), senser é quem sente, pensa ou percebe algo; é o participante que experienciador da emoção.
} 
O adolescente encontra-se como avaliador adicional (appraiser), cujo termo, sugerido por Martin e White (2005), aponta a qualificação do que outra pessoa sente. Pode-se observar o appraiser no enunciado o sofrimento das mães que perderão os filhos cada veis mais cedo, no qual o socioeducando optou por uma estrutura frasal com escolhas lexicais que o distanciaram de seu grupo de socioeducandos. Dessa forma, João mostra-se totalmente contrário à redução da maioridade penal.

(105) Eu sou a favor porque, pra mim, lugar de bandido é na cadeia porque pra ele ter um uma ressocialização e não continuar cometendo crimes na sociedade, ele tem que ter uma reclusão.

(CMB, relato de Emanuel, 16 a)

Diferente das vozes dos adolescentes em estado de reclusão, no excerto (105), Emanuel mostra-se favorável à redução da maioridade penal. O estudante sinaliza fazer o julgamento de sanção social, pois, para ele, devem ser aplicadas penalidades e punições, no caso a prisão (cadeia), para aqueles que infringirem as regras sociais ao cometerem, segundo ele, crimes na sociedade, como se pode observar no enunciado ele tem de ter uma reclusão. Dessa forma, Emanuel deixa transparecer que os adolescentes envolvidos com delitos e infrações devem ficar apreendidos sem a possibilidade de retornar ao convívio social, até que sejam ressocializados. Pelo exposto, então, pode-se observar que o tipo julgamento negativo de sanção social encontra-se no subtipo de condenação, consequentemente, na execução de leis penais.

Conforme explicitado no texto, há uma importante relação, mediada pelo Processo Relacional Atributivo ser em lugar de bandido é na cadeia, na qual o Portador é lugar de bandido e o Atributo Circunstancial de Localização na cadeia. Ressalte-se que o julgamento negativo é realizado lexicalmente, nesse caso, por bandido. Ademais, salienta-se que essa relação de Portador e Atributo Circunstancial de Localização parece ecoar a opinião de parte da sociedade brasileira, no que tange à redução da maioridade penal e à apreensão de adolescentes infratores, ou seja, quem comete delitos deve ser tirado do convívio social e levado para a cadeia, tendo esse lugar meios para ressocializar ou não o indivíduo, tendo salubridade ou não, recuperando ou não quem cometeu o ato delituoso.

(106) Eu sou a favor, porque, em minha opinião, eu acredito que se a pessoa tem é :.:: idade, consciência de cometer um crime, se a pessoa tem idade suficiente para cometer um crime, um assalto, um homicídio, o que for, ela também tem idade suficiente pra sofrer as consequências como qualquer outra pessoa com maior idade que sofre essas 
consequências também. Por exemplo: aos quinze anos ou até mesmo aos doze anos eu já sabia, já tinha consciência do que é certo e do que é errado, acho que qualquer outro adolescente tem e ele sabe que é errado cometer um crime. Ele vê que é errado e tem consciência disso. Então ele também tem que ter consciência para saber que tem idade suficiente para sofrer as consequências.

(CMB, relato de Dalila, 17a)

Para Dalila, conforme exposto no excerto (106), o adolescente que comete infração tem consciência do que pode ou não ser feito. Em, se a pessoa tem é :::: idade, consciência de cometer um crime, pode-se notar um julgamento de estima social com a subcategoria de capacidade. Nessa perspectiva, a consciência do que é certo ou errado é o fator determinante para o adolescente ser julgado e sofrer as consequências dos seus atos, como aponta a estudante no enunciado: se cometer um crime, um assalto, um homicídio, o que for, ela também tem idade suficiente pra sofrer as consequências como qualquer outra pessoa com maior idade que sofre essas consequências também. Sendo assim, para Dalila, o adolescente infrator deve ser penalizado e sofrer as devidas consequências, ou seja, ser apreendido. Nesse caso, como se pode observar, há um julgamento de sanção social com o enunciado pra sofrer as consequências.

Além disso, a adolescente faz um autojulgamento quando se mostra como exemplo de alguém que tem consciência de seus próprios atos. É possível identificar, dessa forma, o agente elocutor - Dalila - representado pelo pronome $e u$, ao expressar sua própria avaliação. A auto-avaliação explícita da adolescente é realizada pelo epíteto consciência. Portanto, considera-se que o autojulgamento da estudante destaca a subcategoria de capacidade, pois ela se define como uma pessoa que "contempla os níveis de competência e habilidade" (MARTIN, 200, p. 156) de saber o que é certo e o que é errado.

Observa-se que, por último, a adolescente retoma e corrobora a ideia de sanção social e, por meio da modalização deôntica na categoria de obrigação, nesse caso moral e interna, tem que ter, ditada pelo epíteto consciência, como se pode observar no enunciado então ele também tem que ter consciência para saber que tem idade suficiente para sofrer as consequências. Com isso, ressalta a opinião de que o adolescente infrator deve ser punido de acordo com os atos cometidos.

(107) Eu sou a favor da redução da maioridade penal porque é:::: isso pode resultar no decréscimo de crimes e quem é menor de 18 anos usa como argumento para cometer crimes porque eles não vão passar tanto tempo assim na cadeia e também quem é maior de 18 anos, eles recrutam menores de 18 anos também em algumas vezes para cometer 
crimes porque eles sabem que é:: eles não vão passar muito tempo na cadeia, então daqui a pouco eles estão de volta.

(CMB, relato de Mateus, 17a)

No excerto (107), Mateus utiliza a modalidade epistêmica, no eixo da possibilidade, pode resultar, para explicar sua opinião de ser favorável à redução da maioridade penal, como se observa em isso pode resultar no decréscimo de crimes. A sanção social é realizada no primeiro enunciado da fala do estudante em eu sou a favor da redução da maioridade penal, pois, diante da proposta de redução da maioridade penal, o adolescente de 18 (dezoito) anos para 16 (dezesseis) anos de idade, será, ao invés de apreendido, preso e terá a pena prolongada, de acordo com o crime praticado.

Segundo Mateus, o adolescente infrator comete os delitos por saber que não ficará muito tempo na Unidade de Internação. Mas, por sua vez, os maiores de 18 anos recrutam esses adolescentes para praticarem infrações e delitos. Para o estudante, a apreensão do adolescente que comete infrações e delitos e a redução da maioridade penal são necessárias para que haja um decréscimo de crimes.

Mais uma vez são observadas vozes em posições contrárias. Por um lado, os socioeducandos que externam o subtipo da avaliatividade afeto (affect) concernente às emoções e sentimentos, sendo positivo ou negativo, bem como a estima social que se referem à redução da maioridade penal. Isso, porque estão dentro de um sistema de internação que, aparentemente, não consegue ressocializá-los. Tal redução, no contexto em que se encontram, põe os socioeducandos bem próximos ao instrumento de punição prevista no Código Penal. Por outro lado, encontram-se os adolescentes do CMB, que manifestam a preocupação em retirar, do seu meio social, os adolescentes infratores que cometem delitos, os quais, segundo os estudantes, têm consciência de seus atos, do que é certo e do que é errado. Dessa forma, utilizam a sanção social como um meio de avaliar para punir e penalizar os adolescentes que cometem atos infracionais.

Nesse contexto de posições contrárias, diferenças e exclusão do meio social, podem ser observadas as marcas de identidade e diferença nos relatos dos estudantes do CMB. Conforme Silva T. (2009), 
a identidade e a diferença se traduzem, assim, em declarações sobre quem pertence e sobre quem não pertence, sobre quem está incluído e quem está excluído. Afirmar a identidade significa demarcar fronteiras, significa fazer distinções entre o que fica dentro e o que fica fora. A identidade está sempre ligada a uma forte separação entre "nós" e "eles". Essa demarcação de fronteiras, essa separação e distinção, supõem e, ao mesmo tempo, afirmam e reafirmam relações de poder. (SILVA T., 2009, p. 82)

As declarações, nos relatos orais, dos estudantes do CMB estão permeadas de indicadores que demarcam as fronteiras de separação e distinção do indivíduo que está incluído na sociedade e do que está excluído. A classificação dos "indicadores de posições-de sujeito" (SILVA T., 2009, p.82) - nós e eles - evidencia-se, no momento em que todos são adolescentes, mas há, de forma explícita, a divisão do "nós" (estudantes): aqueles que estão vivendo e convivendo em sociedade; e "eles" (adolescentes que cometem infrações) os que, segundo os estudantes, devem ser banidos do meio social, ou seja, a ideia de discriminação e exclusão.

Nessa esteira, evoco Tajfel $(1978,1981)$ no que se refere ao sentimento de pertença a um grupo social no tocante à ideia de exclusão, pois há um comportamento de favoritismo do endogrupo (ingroup), em detrimento do exogrupo (outgroup). Nessa perspectiva, é observada uma relação com a distinção positiva do próprio endogrupo, nesse caso, os estudantes do CMB, quando se compara com o exogrupo, o grupo dos socioeducandos da UISM. Esse sentimento de pertença mostra que a redução da maioridade penal não será uma lei voltada para o estudante (nós), mas, sim, para os adolescentes que cometem infração (eles). Essa marcação de oposição entre o nós e o eles é relevante, pois são posições contrárias que tendem a se refletir em processos que motivam atitudes e ações discriminatórias por parte dos estudantes do CMB em relação ao grupo dos socioeducandos da UISM.

Além do dueto das vozes dos socioeducandos da UISM e dos estudantes do CMB, pude observar outro dueto não menos importante: o primeiro refere-se às leis que pregam um sistema de socioeducação para reeducar e ressocializar os socioeducandos. O segundo envolve as vozes dos próprios socioeducandos e dos socioeducadores (agentes de polícia e pedagogos) que integram a equipe de segurança e educação da Unidade de Internação. Vejamos.

\subsection{O CRUZAMENTO DE TEXTOS LEGAIS VERSUS VOZES DIVERGENTES}

Nesta seção, registro algumas reflexões analíticas a respeito do que é colocado em prática ou não nos Documentos Oficiais de acordo com relatos de socioeducandos da UISM e 
profissionais que trabalham na Unidade de Internação. Para tanto, tomo como base a perspectiva teórica sugerida por Chouliaraki e Fairclough (1999) e Fairclough (2001), para os quais a linguagem se constitui em um elemento basilar da vida social, não apenas como reprodutora das práticas sociais e das ideologias, mas também como uma ferramenta para a transformação social. Dois documentos servem de base para um breve paralelo entre as vozes institucionais e as vozes abafadas, no caso dos socioeducandos: o artigo 124 do Estatuto da Criança e do Adolescente e o artigo $4^{\circ}$ do Regimento Interno das Unidades de Internação, confrontando-se com os relatos dos socioeducandos. Trata-se de um paralelo por contraste entre Documentos Oficiais e relatos dos socioeducandos.

\section{Quadro 5.1 - Intertextualidade entre o RIUI e do ECA}

\begin{tabular}{|c|c|}
\hline $\begin{array}{l}\text { Artigo } 4^{\circ} \text { - As medidas socioeducativas possuem } \\
\text { uma dimensão jurídico-sancionatória e uma } \\
\text { dimensão substancial ético-pedagógica. } \\
\S 1^{\circ} \text { - O regime de Internação terá prioridade nas } \\
\text { medias pedagógicas, na participação coletiva da } \\
\text { comunidade socioeducativa, no protagonismo dos } \\
\text { socioeducandos, no atendimento especializado, na } \\
\text { transparência dos procedimentos de segurança e } \\
\text { disciplina, na escolarização, na oferta de } \\
\text { oportunidades de profissionalização } \\
\text { empregabilidade, na garantia de acesso às } \\
\text { atividades de lazer, cultura e esporte. } \\
\text { (RIUI, 2013, p.4,) }\end{array}$ & $\begin{array}{l}\text { Art. 124. São direitos do adolescente privado de } \\
\text { liberdade, entre outros, os seguintes: } \\
\text { I ... X } \\
\text { XI - receber escolarização e profissionalização; } \\
\underline{\text { XII - realizar atividades culturais, esportivas e de }} \\
\underline{\text { lazer; }} \\
\text { (ECA, Livro II, Parte Especial, Título } \\
\text { III - Da Prática de Ato Infracional, } \\
\text { Capítulo IV - Das Medidas } \\
\text { Socioeducativas, Seção VII - Da } \\
\text { Internação) }\end{array}$ \\
\hline
\end{tabular}

Fonte: elaborado pela autora

De acordo com o Quadro 5.1, observa-se uma intertextualidade, entre o Regimento Interno das Unidades de Internação e o Estatuto da Criança e do Adolescente, referente à escolarização, profissionalização, realização de atividades culturais, esportivas e de lazer no sistema socioeducativo. Conforme Fairclough (2001, p.114) “a intertextualidade diz respeito à propriedade que têm os textos de serem cheios de fragmentos de outros". Nesse sentido, o autor (2001) distingue a intertextualidade manifesta da intertextualidade constitutiva (interdiscursividade). ${ }^{41}$ No caso dos dois textos do Quadro 5.1, há uma relação de

\footnotetext{
${ }^{41}$ Fairclough (2001) refere-se à intertextualidade manifesta como a constituição heterogênea de textos por meio de outros textos específicos, o que torna possível observar que outros textos estão explicitamente presentes no texto em análise. Já a intertextualidade constitutiva de um texto é observada por meio da configuração de convenções discursivas que entram em sua produção.
} 
intertextualidade manifesta, pois se trata da representação do discurso, por meio da paráfrase, do RIUI, daquilo que está previsto no ECA.

Dessa forma, o artigo 124 do ECA e incisos XI e XII anunciam que são direitos do adolescente privado de liberdade, entre outros, receber escolarização e profissionalização, bem como realizar atividades culturais, esportivas e de lazer. O RIUI prioriza as medidas pedagógicas, a participação coletiva da comunidade socioeducativa, o protagonismo dos socioeducandos, o atendimento especializado, a transparência dos procedimentos de segurança e disciplina, a escolarização, a oferta de oportunidades de profissionalização e empregabilidade, a garantia de acesso às atividades de lazer, cultura e esporte. Atenta-se para o fato de que ambos os documentos tratam do direito do socioeducando à educação, profissionalização, acesso a atividades de cultura, esporte e lazer. Nessa tangente, partindo-se do pressuposto de que direito é um poder legítimo do cidadão, independente da condição social, cor, etnia ou religião, o que está escrito nos Documentos Oficiais deveria ser acatado e respeitado. Porém, parte das importantes ações voltadas para a reeducação de adolescentes em conflito com a lei não é realizada, aplicada, tampouco cumprida, como se pode observar, a seguir, no relato de socioeducando.

(108) A escola... Tipo, a pessoa tá ino pa conhecê, só, porque, tipo, muitas veiz vai um dia sim, um dia não! Um dia sim, cinco não! A escola é dentro do quarto, a pessoa que tivé um interesse ela vai pegá um livro e estudá!

(UISM, relato de Tomé, 17a)

No excerto (108), Tomé relata a falta de regularidade em frequentar a escola dentro da Unidade de Internação. O adolescente utiliza as circunstâncias de tempo para apontar uma rotina educacional que não existe: um dia sim, um dia não! Um dia sim, cinco não. Cabe destacar que os socioeducandos não vão às aulas todos os dias, ou porque estão cumprindo medidas socioeducativas, ou porque não têm aula por falta de professores, ou mesmo por falta de efetivo de agentes de polícia para fazerem o deslocamento dos socioeducandos dos módulos até a escola. O adolescente relaciona a escola ao quarto (cela), ao utilizar a circunstância de localização em a escola é dentro do quarto. A educação escolar parece estar em segundo ou terceiro plano na Unidade, o que representa ser um dos grandes motivos pelos quais o sistema socioeducativo parece não cumprir o que reza o Estatuto da Criança e do Adolescente e o Regimento Interno das Unidades de Internação. 
Fazendo uma ressalva sobre essa situação, pude observar, na UISM, que uma das formas de castigar os socioeducandos é a não participação deles na aula. Isso, porque a escola é uma forma de liberdade para os socioeducandos, pois eles ficam quase 24 horas no quarto (cela) e, quando eles têm aula, é o momento que eles saem e caminham até as salas de aula. Quanto ao evento da aula, na escola, um dos agentes de polícia que trabalha na UISM relatou o seguinte fato:

(109) Olha, a educação ela poderia ser um pouco melhor! Até pelo, até pela falta de funcionários, a gente sofre muito com falta de efetivo. Né? Porque::.:, já que eles estão internados no sistema fechado, depende muito da nossa vigilância! Né? No deslocamento de um módulo pra escola. Da escola pro módulo. Às veiz, com atendimento técnico, um se machuca, leva na enfermaria. Então tem que ter funcionário, nós hoje não temos! Nós temos uma dificuldade muito grande nesse deslocamentos! Está prejudicando a educação dos adolescentes, porque eles não tão quase frequentando as aulas! A gente faz uma, é::::, tipo um sorteio, tira um módulo um dia, aquele que foi ontem já num vai hoje, vai o seguinte, e eles ficam cobrando: "ah, num vô pra escola!" Mas é polícia pela falta de efetivo! Então, a educação realmente... Num é do jeito que a gente queria que fosse! Né?

(UISM, relato de um Agente de Polícia)

No excerto (109), o Agente de Polícia aponta que um dos problemas da educação dentro da Unidade de Internação é a carência de policiais para fazer o deslocamento dos adolescentes dos módulos para a escola, que fica próxima às celas dos módulos. $\mathrm{O}$ funcionário topicaliza seu relato chamando atenção ao utilizar o processo mental no imperativo olhar em Olha, para, logo após, modalizar sua fala ao se referir à escola, consequentemente, à educação, como se pode observar em a educação ela poderia ser um pouco melhor. O Agente, quando faz esse tipo de construção, parece apontar uma falha no sistema de reeducação e socioeducação da UISM. No relato, o policial usa o termo a gente em a gente sofre muito com falta de efetivo e a gente faz uma, é::.:, tipo um sorteio. O uso desse termo é significativo, pois envolve dois níveis semântico-discursivos diferentes. Conforme Silva (2013),

apesar do equilíbrio alcançado no nível sintático, em termos de previsibilidade de traços formais, tais como a perda definitiva do plural [ $\varnothing$-s] e posição sintática mais fixa, bem como maior previsibilidade em termos de uso, o emprego corrente e recorrente do termo parece oscilar ainda no nível semântico-discursivo, visto que ora a locução pronominal a gente exibe o traço $[+\mathrm{EU}]$ incluindo o falante, o que favorece o envolvimento com o(s) outro(s) na interação, ora carrega um sentido genérico, dando margem à interpretação da ausência do traço [Ø-eu], o que parece favorecer a pessoa 
que fala, como se fosse um traço semântico de neutralidade, imprimindo um grau de distanciamento do falante com o seu discurso, como uma estratégia de não-comprometimento com a própria palavra (SILVA, 2013, p. 258).

Os dois casos da locução pronominal a gente na fala do policial apontam para níveis semântico-discursivos diferenciados, pois em a gente sofre muito com falta de efetivo, exibese o traço [+EU] incluindo o falante como se ele fosse a Unidade de Internação, visto que ele utiliza o processo mental emotivo sofrer por não ter condições de fazer o deslocamento dos socioeducandos para atividades que eles deveriam participar. Porém, no segmento oracional $a$ gente faz uma, é::.:, tipo um sorteio, parece haver um grau de distanciamento do falante com seu discurso uma vez que não se sabe quem faz esse sorteio.

A Gradação por tipo de Força-Intensificação nas formas de Isolamento, com o uso do intensificador muito e Repetição com o emprego do processo ter é encontrada no enunciado tem que ter funcionário, nós hoje não temos! Nós temos uma dificuldade muito grande nesse deslocamentos. Observe-se, dessa forma, no fragmento, que parece ocorrer uma negligência por parte do Estado quando o agente anuncia que deve haver uma mudança nas práticas sociais dentro da Unidade de Internação.

Entretanto, essa problemática vem de convenções discursivas naturalizadas, pois não há efetivo de policiais para levar os socioeducandos à escola, então, eles não vão e, consequentemente, ficam ociosos na cela. Isso, segundo o policial, está prejudicando a educação dos adolescentes, porque eles não tão quase frequentando as aulas! A gente faz. uma, é, tipo um sorteio, tira um módulo um dia, aquele que foi ontem já num vai hoje, vai o seguinte, e eles ficam cobrando: "ah, num vô pra escola!”. Observe-se que é feito um sorteio para participação do adolescente na aula nesse dia. O socioeducando que participou da aula, no dia anterior, não participará no próximo dia.

Tais ações emergem negativamente na vida dos socioeducandos que necessitam de educação como ferramenta para que sua (re)educação social seja estabelecida. Cabe ressaltar que o discurso de reintegração e ressocialização do socioeducando deveria estar articulado às práticas sociais educacionais e acionais que efetivamente funcionassem, mas que parecem não funcionar.

Outra questão nevrálgica na Unidade de Internação, além da educacional, é a “oferta de oportunidades de profissionalização e empregabilidade, na garantia de acesso às atividades de lazer, cultura e esporte" (RIUI, 2013, p.4). Vejamos, abaixo, o relato do socioeducando referente a essas questões. 
(110) Gostaria que tivesse esportes! Esporte, lazer! Uns curso profissionalizante! Que não adianta a pessoa entrá aqui dentro, passá esse tempo todo aqui dentro e saí no escuro! Sem sabê nada! Sem tê um curso...! Fala: "não, mas seu nome não vai sê exposto!” Mas tamém eles num, num dá uma forma de a pessoa chegá lá fora tê um curso pra se apresentá, arranjá um, um emprego com mais facilidade. Eu mermo, eu, eu no meu ponto de vista, eu não me acho ressocializado totalmente pelo sistema socioeducativo! Eu acho...eu me acho ressocializado pela minha força de vontade! Que aqui dentro mermo, os projeto que tem assim, que eu tamém achei muito bom foi do seu Abdallah. ((Projeto de leitura)) Pela Unidade, se fosse exercê pela Unidade... Só tranca! E não só aqui dentro como lá fora tamém! Mas, oportunidade não só na cidade melhores condição, mais como na periferia tamém!

(UISM, relato de Tomé, 17a)

No excerto (110), Tomé exprime o desejo de que tivesse, na Unidade de Internação, a prática de algum esporte, uma forma de lazer e cursos profissionalizantes na UISM. Esse discurso de súplicas, entretanto, vai à contramão do artigo $4^{\circ}$ do RIUI e do artigo 124 do ECA que pregam o esporte, o lazer e cursos profissionalizantes como meios de uma socioeducação. O adolescente utiliza uma forma de gradação temporal e espacial, com o uso dos processos entrar, passar e sair da Unidade de Internação. Ressalte-se que a circunstância de modo no escuro, em sair no escuro, representa um elemento de natureza catafórica dos referentes sem sabê nada! Sem tê um curso. Parece haver a preocupação, além do tempo presente, também com um futuro próximo, porque, para o adolescente, o sistema socioeducativo não é eficaz, pois não oferece educação adequada e cursos profissionalizantes.

Dessa forma, o socioeducando não se sente ressocializado por meio do sistema socioeducativo, mas por sua própria força de vontade. Isso pode ser comprovado com a primeira expressão modalizadora eu acho que, nesse caso, revela um maior grau de engajamento do adolescente no que tange ao conteúdo proposicional abordado. Resulta que o adolescente aponta para a conclusão de que o sistema não ressocializa, porém a força de vontade, sim, como se pode observar em eu acho... eu me acho ressocializado pela minha força de vontade. ${ }^{42}$

A relação de presente e futuro aparece no enunciado mas tamém eles num, num dá uma forma de a pessoa chegá lá fora, tê um curso pra se apresentá, arranjá um, um emprego com mais facilidade. A escolha do tempo verbal, aqui, parece estar atrelada à preocupação do que está acontecendo no momento atual e do que irá acontecer quando Tomé sair da Unidade, o que posteriormente é anunciado como clamor tanto pela falta de oportunidade na cidade, como também na periferia.

\footnotetext{
42 Segundo Koch $(2011$, p.133), consideram-se modalizadores todos os elementos linguísticos diretamente ligados ao evento do enunciado e que funcionam como indicadores das intenções, sentimentos e atitudes do locutor em relação a seu discurso, como é o caso da expressão “eu acho".
} 
$\mathrm{O}$ adolescente vincula a falta de oportunidades à tranca em pela Unidade, se fosse exercê pela Unidade... Só tranca! E não só aqui dentro como lá fora tamém! O termo lexical tranca sugere, no relato do socioeducando, uma punição que existe dentro e fora do sistema socioeducativo: dentro, porque não há, segundo ele, escola e cursos profissionalizantes; fora, pois ele pede alguma oportunidade de vida, não somente na cidade, como também na periferia. Nessa esteira, de privação de liberdade e punição, evoco as palavras de Garland (1995), para quem

a violência das penas é geralmente sanitária, situacional e de pouca visibilidade, o conflito entre as sensibilidades civilizadas e a frequentemente brutal rotina da punição é minimizada e feita tolerável. A punição moderna, portanto, é ordenada institucionalmente e representada em um discurso que nega a violência inerente das suas práticas. (GARLAND, 1995, p. 243)

Dessa forma, nota-se que a noção de reeducação e ressocialização parece estar somente no discurso dissimulado das leis, pois não há uma efetiva aplicação nas práticas sociais dos socioeducandos, que ficam ociosos e trancados em celas pensando na fuga da Unidade de Internação, no crime que irão cometer quando de lá saírem, ou mesmo no atentado a eles mesmos (suicídio). O tempo de privação de liberdade do adolescente deveria existir para que ele retornasse à sociedade com uma nova concepção de pensamento e uma mudança positiva de comportamento. Porém, as mudanças de visão de mundo que deveriam ocorrer com os socioeducandos, na maioria dos casos, não ocorrem, pois, quando o adolescente está na Unidade de Internação, as consequências de danos psicológicos agravamse, quase sempre, para pior. Em uma vertente profissional, veremos um relato sobre a frustração de uma pedagoga da Unidade de Internação referente ao trabalho limitado que faz dentro da UISM.

(111) Então, a questão de cursos dentro da escola, então, a gente, é tudo muito capenga, muito, muito, muito ainda, muito deficitário dentro da medida, né? Esse tipo de fornecimento desse atendimento ao público é muito pequeno ainda, né? Há um déficit muito grande de cursos, de profissionais, de, a gente não consegue inserir os meninos nas atividades... Então, é, nesse ponto, eu fico frustrada! Porque eu não consigo realmente, fazer o que eu sei fazer, o que eu conseguiria fazer! Por causa das limitações do próprio sistema. Mas também, em contrapartida, vejo que eu posso ajudá-los muito em outros aspectos, né? Que é aquele apoio, aquele crédito que eu dou pra eles! Porque quando eu atendo um jovem aqui, eu não atendo como uma mera profissional, eu atendo como ser humano, também. Eu olho pra esse menino como... Acreditando que é possível realmente, ele sair... dessa vida!

(UISM, relato de uma Pedagoga) 
No excerto (111), a Pedagoga utiliza, em sua fala, a lógica explanatória (FAIRCLOUGH, 2003) que ressalta a relação causal de eventos (ou a falta desses eventos), práticas e estruturas que acentuam o problema de não ter educação e cursos profissionalizantes para os socioeducandos. O trabalho de socioeducação que deveria ser feito, então, não o é, pois há várias limitações no sistema, tais como a falta de profissionais e a falta de oferta de cursos.

A avaliação do sistema socioeducativo é notória. O Sistema de Avaliatividade é expresso por meio do subtipo afeto negativo apontando a insatisfação de não ter condições de trabalhar em eu fico frustrada. Entretanto, o afeto positivo também aparece em seu relato na forma de felicidade, quando se refere ao trabalho de (inter)ação com o socioeducando, como no enunciado vejo que eu posso ajudá-los muito em outros aspectos, né?

Vale observar que o julgamento também é identificado na forma de estima social no que concerne à capacidade em a questão de cursos dentro da escola, então, a gente, é tudo muito capenga, muito, muito, muito ainda, muito deficitário dentro da medida. A capacidade também aparece em porque eu não consigo realmente fazer o que eu sei fazer, o que eu conseguiria fazer. Além disso, a profissional faz um autojulgamento em eu atendo um jovem aqui, eu não atendo como uma mera profissional, eu atendo como ser humano, também. Nesse caso, pondera-se que há uma confirmação de uma determinada postura humanizada e sensível nos atendimentos, o que se enquadra no autojulgamento do subtipo normalidade, visto que existe uma forma peculiar de tratar os socioeducandos.

No relato da profissional, o subsistema de Gradação por tipo Força-Intensificação nas formas de Isolamento e por Repetição. O texto é marcado pelos intensificadores muito capenga (Afeto negativo), muito, muito, muito ainda, muito deficitário (Afeto negativo), um déficit muito grande (Afeto negativo), o que revela a atitude de Afeto realizada pelos atributos sendo modificada por graus de intensidade que tornam muito difíceis e precárias as condições de realizar um trabalho eficaz.

Os operadores argumentativos por causa e porque em porque eu não consigo realmente, fazer o que eu sei fazer, o que eu conseguiria fazer e por causa das limitações do próprio sistema introduzem importantes circunstâncias causais que apontam para problemas existentes na Unidade de Internação. Esses problemas, certamente, impedem que seja feito um trabalho eficaz para recuperar os adolescentes que estarão, novamente, nas ruas. 


\section{Algumas considerações analíticas}

Nas análises desenvolvidas, neste capítulo, busquei tecer algumas considerações referentes a questões pertinentes às relações linguístico-discursivas nos relatos de adolescentes dos dois contextos: do CMB e da UISM. Foram apresentadas categorias linguístico-discursivas identificadas e agrupadas de acordo com a natureza das recorrências encontradas nesses relatos. Essas categorias evidenciam a representação dos socioeducandos e estudantes no que tange à paternidade, bem como a conexão da droga e do vício com o crime, em uma relação de razão e consequência. Além dessas, a categoria obediência foi identificada, a qual foi subdividida em resistência, limite e respeito, seguida por aprendizado nas instituições. Por fim, a última categoria referiu-se ao futuro e pretensões dos adolescentes.

As avaliações expressas por atitudes nos textos orais e escritos a respeito da redução da maioridade penal contribuem para atestar que as vozes dos adolescentes dos dois contextos são evidentemente contrastivas e contrárias. Por um lado, os socioeducandos da UISM são contrários à redução. Isso, porque estão inseridos em um sistema de internação que não mostra um resultado positivo na recuperação de socioeducandos. Por outro, os estudantes do CMB mostram o receio de ter, em seu meio social, adolescentes infratores que, supostamente, têm consciência de seus atos e, mesmo assim, cometem delitos. Portanto, os estudantes defendem, diante do modus operandi delituoso, a redução da maioridade penal. ${ }^{43}$ Dessa forma, utilizam, em seus relatos, a sanção social como uma forma para punir e penalizar os adolescentes que cometem infrações e delitos.

Cabe destacar, também, o cruzamento de textos legais versus vozes divergentes, pois o discurso que prega a lei é aquele que prioriza, no regime de internação, as medidas pedagógicas, a participação coletiva da comunidade socioeducativa, o protagonismo dos socioeducandos, o atendimento especializado, na transparência dos procedimentos de segurança e disciplina, na escolarização, na oferta de oportunidades de profissionalização e empregabilidade, a garantia de acesso às atividades de lazer, cultura e esporte. Porém, na prática social da UISM, não se consegue priorizar o que a lei prega e o que torna essa lei deficitária e descumprida, como se pôde observar nos relatos do socioeducando, da pedagoga e do agente. Cabe, aqui, evocar as palavras de Bizatto e Bizatto (2014):

Ao Estado e às entidades próprias, cabe dar assistência e corroborar para a reeducação social da classe desviada, mas o Estado, com múltiplas

\footnotetext{
${ }^{43}$ No âmbito jurídico, aplica-se o modus operandi para identificar o perfil de quem comete o delito.
} 
atividades, esquece essa área, donde aumentam gradativamente os atos infracionais. (BIZATTO; BIZATTO, 2014, p.127)

Sendo assim, com base nos dados empíricos analisados no presente capítulo, urge a necessidade do comprometimento estatal e que sejam estabelecidas políticas públicas eficazes, que haja um engajamento da sociedade em geral e também de todos que estão envolvidos no sistema de socioeducação para fazer valer o que reza o ECA e o que prioriza o RIUI. Isso para que a real situação da reeducação e reinserção social que parecem utópicas tornem-se concretas. Ressalte-se que as políticas públicas aqui mencionadas não devem estar voltadas somente para o socioeducando, mas para a comunidade em geral, pois a criança que comete um delito, se não tiver acompanhamento, tornar-se-á, provavelmente, um adolescente infrator e, consequentemente, um adulto criminoso. Há fatores agravantes que corroboram para que os adolescentes entrem para o mundo do crime, tais como o abandono da criança e do adolescente, a baixa ou nenhuma escolaridade, a falta de oportunidades profissionais, a condição precária de sobrevivência, bem como a falta de estrutura familiar. 


\section{CONSIDERAÇÕES FINAIS}

Aceitar o desafio de aproximar duas instituições relativamente distantes _ o Colégio Militar de Brasília e a Unidade de Internação de Santa Maria _ dentro de um mesmo plano de estudo voltado para os níveis linguístico e discursivo, levou-me à descoberta de lacunas existentes em Documentos Oficiais relativos a adolescentes, sobretudo, no que concerne às formas discursivas de representação, bem como às práticas que se entrecruzam na heterogeneidade desses contextos socioculturais. Ademais, as representações foram ponto de destaque, na medida em que se observou como eram e são caracterizados os adolescentes em situação de vulnerabilidade no âmbito dos Documentos Oficiais. Ao longo do estudo, identifiquei e procurei descrever, bem como interpretar, as representações linguísticodiscursivas voltadas para adolescentes, assim como seus modos de (des)construção de seus mundos (físico, biológico e social).

Para tanto, foram utilizadas as ferramentas conceptuais da noção de discurso como prática social da ADC de Fairclough (2001) e a construção teórico-descritiva da LSF baseada Halliday (1994) e ampliada em Halliday e Matthiessen (2004). Sob a ótica de Fairclough, pude visualizar a exterioridade da linguagem; já com Halliday e Matthiessen, observei a interioridade do texto; e, finalmente, com Martin (2000), Martin e White (2005) e Martin e Rose (2007) foi possível dimensionar a Avaliatividade no discurso.

Em um primeiro momento, levei a cabo a análise de dados da parte documental a partir de Documentos Oficiais como a Constituição Federal de 1988, o Estatuto da Criança e do Adolescente, o Regimento Interno do Colégio Militar e o Regimento Interno das Unidades de Internação e seus referentes como o manual do aluno do CMB e o Projeto Político Pedagógico das Medidas Socioeducativas no Distrito Federal. Logo após, realizei uma microanálise dos relatos orais (entrevistas) e de textos escritos, procedimentos que me auxiliaram a compreender o contexto sociocultural dos adolescentes em termos de macroanálise. Mediante a retomada das cinco perguntas que motivaram a pesquisa, elenco as considerações sobre os resultados alcançados neste estudo.

No primeiro capítulo, foram discutidos conceitos, características e comportamentos que envolvem o foco deste trabalho: os adolescentes. Dentre as características, destacam-se os adolescentes associais, os inadaptados sociais, os pré-delinquentes e os delinquentes, que podem apresentar comportamentos inadequados e agressivos. Apontei como prováveis causas desses perfis a falta de estrutura familiar, o consumo de drogas, problemas mentais, o descaso do poder público, bem como a falta de educação de qualidade. Esses adolescentes são casos 
que me permitem estabelecer uma forma de vulnerabilidade pessoal e social, o que acarreta, muitas vezes, uma identidade enfraquecida desses indivíduos. Em seguida, discuti as duas instituições selecionadas no estudo e pontuei que, em ambas, é frequente o discurso disciplinador em suas práticas sociais, embora em uma delas o traço semântico da punição ganhe mais destaque. Além disso, finalizei o capítulo abordando a importância da educação na vida da criança e do adolescente.

No capítulo 2, explanei a respeito das duas teorias metodológicas que me propiciaram apresentar aspectos discursivos, ainda que vistos também sob uma perspectiva social. A primeira, a Linguística Sistêmico-Funcional, foi utilizada como uma ferramenta de análise da interioridade da linguagem, para que eu pudesse observar a língua em uso, em de um estudo linguístico-discursivo a partir do contexto de cultura no qual os textos estão inseridos. Sob essa perspectiva, além de ser uma teoria de descrição gramatical, ela fornece instrumentos de descrição, uma técnica e uma metalinguagem que são úteis para a análise de textos. A Análise de Discurso Crítica, na proposta fairclougheana, permitiu-me, em uma dimensão textual, interpretativa, crítica e explicativa, analisar dados vistos como partes de eventos sociais, uma vez que uma das maneiras pelas quais as pessoas agem e interagem no curso dos eventos é pela linguagem (FAIRCLOUGH, 2003). A linguagem, portanto, faz parte da sociedade e é um elemento inerente desta.

No capítulo 3, discuti a metodologia qualitativa (descritiva e interpretativa) de natureza etnográfica, visto que esse tipo de abordagem permite interpretar a realidade de um fato social e, em condições propícias, identificar a realidade dos adolescentes, principalmente a dos socioeducandos, em face à representação discursiva da voz desses atores sociais e dos regimentos internos. Cabe ressaltar que a triangulação dos dados e as várias práticas interpretativas interligadas permitiram alcançar uma visão mais objetiva do problema investigado. Enquanto a Análise de Discurso Crítica e a Linguística Sistêmico-Funcional permitiram tratar as representações linguístico-discursivas a partir de uma perspectiva social, a verticalização comparativa dos dados constituiu um caminho que garantiu a reflexividade em termos das pesquisas levadas a cabo até o momento.

A partir da teoria e da metodologia escolhidas, busquei, nos Capítulos 4 e 5, aproximar respostas às perguntas de pesquisa, já elencadas na Apresentação desta tese. No Capítulo 4, tracei questões pertinentes às representações dos adolescentes, configuradas linguisticamente, em Documentos Oficiais. Desse modo, fiz um percurso histórico-linguístico por leis como o Código de Menores de 1927, o Código de Menores, o ECA, a Constituição Federativa do Brasil e pelos regimentos dos Colégios Militares e das Unidades de Internação, a fim de 
apontar a forma como os adolescentes eram e são representados nos documentos, a fim de responder a seguinte pergunta de pesquisa: quais representações lexicais referentes a adolescentes estão presentes nos Documentos Oficiais? Pude identificar, pelo menos no âmbito do presente estudo, que houve mudança na forma como os adolescentes eram representados e como o são atualmente nos Documentos Oficiais. Antes da Constituição Federal de 1988, os adolescentes, em situação de vulnerabilidade, eram rotulados, de forma discriminatória e pejorativa, por menores, menores abandonados, vadios, delinquentes, libertinos, menores em situação irregular. Hoje, com a nova orientação jurídicoconstitucional, a faixa etária de 12 a 18 anos é representada, na maioria dos documentos, por adolescentes, os quais são sujeitos de direitos e deveres, em estado de vulnerabilidade social ou não.

Ao fazer uma análise dos regimentos como gêneros textuais e ação social, pude responder à segunda pergunta de pesquisa: quais as semelhanças e diferenças entre os regimentos do CMB e da UISM? Nesse sentido, pude observar que estrutura composicional dos dois regimentos tem divisão diferenciada, pois o RIUI não aborda temas relativos às atribuições de servidores de um modo geral. Além disso, com o auxílio da ferramenta computacional WordSmith Tools, observei que em ambos os regimentos os processos materiais se sobressaíram, o que pode ser explicado devido ao gênero textual analisado ser Regimento. Além dos processos materiais, destacaram-se os processos mentais. Ressalte-se que foi possível constatar que o RICM é mais "humanizado" do que o RIUI, pois, no corpo de seu texto, foram feitas escolhas de processos voltados diretamente para benefício do aluno. Quanto aos processos verbais, observou-se que ocorreram de forma equilibrada nos dois regimentos, porém com cargas semânticas diferenciadas.

Observei, entretanto, a falta de cuidado na feitura tanto do Regimento Interno das Unidades de Internação, quanto da Unidade de Internação de Santa Maria. Ambos, como identifiquei, estão incompletos; parecem ter sido feitos somente para constar como documentos existentes. Parece não haver um comprometimento, no que se refere ao conteúdo do regimento, seja com o socioeducando, seja com o funcionário que trabalha nas Unidades de Internação. Dessa forma, pontuo que urge a necessidade de se fazer um Regimento Interno das Unidades de Internação completo, que funcione efetivamente, que seja eficaz para se cumprir o propósito da instituição que é o de (re)educar o adolescente. Esses documentos parecem ser elaborados por servidores que não estão em contato direto com os socioeducandos, e, sim, por alguém que está bem distante das práticas sociais das Unidades de Internação e que trabalham em uma determinada seção ou departamento, por um determinado 
tempo, como pude observar em minhas inúmeras visitas à Secretaria da Criança e do Adolescente. A legislação deveria nascer do contexto, mas parece que isso não ocorre. Ressalto que há três eixos que se imbricam nesta tese: a legislação, as pessoas que estão envolvidas nas ações para que ocorra a socioeducação e os próprios socioeducandos.

Além dessas observações, foram analisados, de forma comparativa, artigos dos dois regimentos que continham temas em comum. Constatei que a marcação das determinações temporais, futuro e presente, indiciaram a asserção de possibilidade e a asserção de fato, visto que o Regimento Interno das Unidades de Internação do DF trata da possibilidade de os socioeducandos terem acesso aos direitos dentro da Unidade e Regimento Interno dos Colégios Militares aponta, de forma taxativa, a preocupação da Instituição em relação ao discente, no momento em que determina os objetivos para o desenvolvimento, formação e progressão do aluno. Os rótulos da cultura negativa (FAIRCLOUGH, 2003, p.23) e as nominalizações também foram encontrados, respectivamente, como diferencial e semelhança nos artigos dos regimentos.

A terceira pergunta de pesquisa concerne às diferenças e às semelhanças dos instrumentos disciplinares indicados por Foucault praticados nos Colégios Militares e nas Unidades de Internação. Nessa esteira, pude observar que são aplicados, nas duas instituições, instrumentos disciplinares com a função de hierarquia, de disciplina, de boa conduta. $\mathrm{O}$ discurso disciplinador, nos dois contextos, tem como pilares o respeito e a obediência, sendo que, no Colégio Militar, além desses elementos, a hierarquia é extremamente valorizada. Contudo, nas Unidades de Internação, para que se alcance ao objetivo esperado, de obediência e boa conduta, em alguns casos, formas de coerção, seja por meio de palavras proferidas, seja por meio da força física. Essas estratégias são utilizadas como formas de tentar disciplinar e (re)educar o socioeducando.

Partindo da ADC, tem-se a noção de poder, o qual está presente nos âmbitos desta tese como pressuposto, pois o poder é a base das práticas discursivas, bem como das relações sociais. Na situação de poder, pude observar uma relação assimétrica, porque é ele que põe alguém em um polo mais alto e alguém em um polo mais baixo. Cabe ressaltar que essa assimetria caracteriza e define uma relação de poder. Ambos os casos são evidenciados por meio dos documentos, do polo mais baixo e do polo mais alto. A análise documental mostra como o poder se traduz nessa assimetria. O regimento comanda e mostra para os comandados, os estudantes e os socioeducandos, o que deve ou não ser feito. Em seguida ao poder e à assimetria, surge a dominação. 
Dessa forma, quando acontece a assimetria, ocorre, consequentemente, uma relação de dominação. Ou seja, um polo que possui mais poder domina o outro com menos poder. Porém, é nesse ponto, na justificativa da dominação, que as duas situações dos contextos desta pesquisa começam a se distanciar, visto que, apesar de os dois grupos reconhecerem e funcionarem por essa assimetria, o CMB justifica essa dominação por uma formação integral do aluno, em termos de educação e cidadania. Já a dominação na UISM é justificada como a necessidade de reinserção do adolescente na sociedade. Sendo assim, a dominação começa a ser justificada de maneiras diferentes nos dois contextos.

Por fim, junto à dominação vem o discurso disciplinador. Esse discurso, no CMB, é incorporado à fala e à identidade dos estudantes. Entretanto, na UISM, o discurso disciplinador é afrontado, contestado e rechaçado. Os dois campos começam juntos e depois vão se abrindo e, dessa forma, criam uma oposição. As duas instituições criam mecanismos e se distanciam no modo de repassar o discurso disciplinador, com a receptividade dos adolescentes de acatar ou rechaçar esse discurso.

No capítulo 5, levantei cinco categorias linguístico-discursivas a partir da microanálise de relatos dos estudantes e dos socioeducandos. Os relatos surgiram durante as entrevistas, realizadas com base nas mesmas perguntas para os dois grupos, o que me permitiu fazer a análise por meio de um paralelo por contraste dos discursos dos adolescentes. Essa parte do trabalho buscou responder as últimas duas perguntas de pesquisa. A quarta pergunta de pesquisa refere-se às categorias linguístico-discursivas encontradas nos relatos dos adolescentes. Identifiquei essas categorias linguístico-discursivas de acordo com a natureza das recorrências encontradas nos relatos dos adolescentes. Pude apontar como categorias a paternidade, bem como a conexão da droga e do vício com o crime, em uma relação de razão e consequência. Além dessas, a categoria obediência foi identificada, a qual foi subdividida em resistência, limite e respeito, seguida por aprendizado nas instituições. Por fim, a última categoria referiu-se ao futuro e pretensões dos adolescentes. Essas categorias relacionadas foram relevantes para analisar a representação dos adolescentes

Para as respostas da quinta pergunta, que versa em que momento os discursos dos adolescentes se alinham e se afastam, retomo uma das categorias acima: a de Futuro. Na categoria de Futuro, tanto os adolescentes do CMB quanto os da UISM parecem apresentar a vontade de estudar e, no futuro, trabalhar. Nesse ponto, seus discursos se alinham. Entretanto, na análise feita com base no Sistema de Avaliatividade, concernente à redução da maioridade penal, os discursos se afastam. As avaliações expressas por atitudes, nos textos orais e escritos, a respeito da redução da maioridade penal contribuíram para a confirmação de que as 
vozes dos adolescentes dos dois contextos são totalmente contrárias. Por um lado, os socioeducandos da UISM são contrários à redução. Por outro, os estudantes do CMB permitem identificar, em seu discurso, a preocupação em banir, do seu meio social, os adolescentes infratores que, supostamente, têm consciência de seus atos e, mesmo assim, cometem delitos e dessa forma são a favor da redução da maioridade penal.

Ressalto, no entanto, que a tese ora apresentada reveste-se de uma prática social transformadora, uma vez que, no período de realização da pesquisa, foram desenvolvidas atividades de leitura e produção de texto, na UISM, que mostraram a alguns colaboradoresparticipantes outras perspectivas de visão de mundo, quais sejam, o gosto pela leitura, o empenho na escrita, a possibilidade de mudança de vida. No âmago desta tese, a inclusão deve predominar e banir, sim, a ideologia da exclusão, do expurgo do outro.

Por outro lado, os dados me permitem destacar o quão contraditório é o discurso do que prega a lei que prioriza, no regime de Internação, as medias pedagógicas, a participação coletiva da comunidade socioeducativa, o protagonismo dos socioeducandos, o atendimento especializado, na transparência dos procedimentos de segurança e disciplina, na escolarização, na oferta de oportunidades de profissionalização e empregabilidade, a garantia de acesso às atividades de lazer, cultura e esporte e a prática social da Unidade de Internação. Ressalte-se o fato de que nos artigos analisados das Unidades de Internação, mostrou-se presente a Dissimulação, um dos modos operacionais da ideologia propostos por Thompson. Esse modo, nesses fragmentos, apareceu como forma de disfarçar uma realidade inexistente, haja vista os poucos casos de adolescentes reintegrados à sociedade. Ademais, identifiquei que a norma procura apontar uma harmonia e um simbolismo utópicos em relação aos socioeducandos. O que parece acontecer, no Regimento Interno das Unidades, é um mascaramento da realidade por meio de um discurso dissimulado.

Essa disparidade de discurso e ação me leva a inferir uma falta de comprometimento, ao que parece do Estado, com o cumprimento dessa tarefa. Faço uma ressalva que, embora exista a escassez de agentes e funcionários, há profissionais comprometidos com o sistema socioeducativo, apesar das difíceis condições da (re)educação e (res)socialização dos adolescentes que, muitas vezes, nunca foram educados ou socializados. Contudo, é necessária uma maior capacitação de todos os envolvidos no sistema. Em poucas palavras, é necessário exigir políticas públicas que revertam a situação de criminalidade e reincidência nas Unidades de Internação e nas penitenciárias, a fim de que seja cumprida a função da socioeducação e que os socioeducandos não fiquem em suas celas à espera de um milagre em suas vidas no 
sentido de se (re)educarem e se (re)inserirem socialmente, pois, futuramente, irão viver e conviver em sociedade.

Além de servir de ponto de partida para subsidiar uma reflexão a caminho das práticas sociais transformadoras, os resultados alcançados significam também uma forma de subsidiar projetos futuros, não só no campo da Linguística, dentro da grande área das Letras, mas também nos demais campos das ciências humanas. Conforme Silva (2015),

Cabe ao meio acadêmico-profissional uma agenda de compromissos de pesquisa que contribua para um verdadeiro "capital social", capacitado para identificar e eliminar causas responsáveis pela fragilidade do sistema brasileiro em conjugar políticas e programas em prol do adolescente, bem como da infância e juventude. Trata-se da proposta de construção de uma rede no âmbito das ciências sociais, balizada por princípios éticos que conduzam saberes em favor dos menos favorecidos. Considera-se necessária uma rede solidária que ultrapasse as fronteiras do debate acadêmico por meio da sensibilização e difusão de práticas discursivas fortalecedoras, com vistas ao resgate de identidades de uma juventude. (SILVA, 2015, p. 91)

Chego ao final desta tese com uma série de considerações que podem ser vistas como forma de contribuição para se refletir sobre adolescentes em situação de vulnerabilidade, em sistema de reclusão ou não. Cabe, neste momento, citar as palavras de Freire (2001), como uma forma de reflexão:

Se, na verdade, não estou no mundo para simplesmente a ele me adaptar, mas para transformá-lo; se não é possível mudá-lo sem um certo sonho ou projeto de mundo, devo usar toda possibilidade que tenha para não apenas falar da minha utopia, mas para participar de práticas com ela coerentes. (FREIRE, 2001, p. 17)

Assim é que meu caminho e meus ideais não se esgotam nesta tese. 


\section{REFERÊNCIAS}

ALVES, R. A alegria de ensinar. Campinas, SP: Papirus, 2000.

AMIM, A.R. Curso de Direito da Criança e do Adolescente: aspectos teóricos e práticos. Kátia R.F.L.A. Maciel (Coord.). 6. ed. São Paulo: Saraiva, 2013.

AMOSSY, R. Imagens de si no discurso: a construção do ethos. 2. ed. São Paulo: Contexto, 2011.

ANDRADE, L.F. Prostituição infanto-juvenil na mídia: estigmatização e ideologia. São Paulo: Educ, 2004.

ANDRE, M. E. D. Etnografia da prática escolar. Campinas: Papirus, 1995.

ARCHER, M. Being Human: the Problem of Agency. Cambridge: Cambridge University Press, 2000.

AUlETE, C. Dicionário Contemporâneo da Língua Portuguêsa. Edição Brasileira. Atual., rev. e aum. por Hamilcar de Garcia e estudo sobre a origem e evolução da Língua Portuguesa por Antenor Nascentes. IV volume. Rio de Janeiro: Editora Delta S.A., 1958.

BAKHTIN, M. Questões de Literatura e de Estética (A Teoria do Romance). 3. ed. São Paulo: UNESP/HUCITEC, 1993.

Marxismo e filosofia da linguagem. 9. ed. São Paulo: HUCITEC, 2002.

Estética da criação verbal. São Paulo: Martins Fontes, 2003.

BARBARA, L.; MACÊDO, C.M.M. Linguística Sistêmico-Funcional para a análise de discurso: um panorama introdutório. Cadernos de Linguagem e Sociedade, Brasília, v. 10, $\mathrm{n}^{\circ} 1$, p. 89-107, 2009.

BARTHES, R. Elements of Semiology. New York: Hill and Wang, The Noonday Press, 1967.

BAUER M.W.; GASKELL, G.; ALLUM, N.C. Qualidade, quantidade e interesses do documento. In: BAUER M.W e GASKELL G. (org). Pesquisa qualitativa com texto: imagem e som: um manual prático. Tradução: Pedrinho A. Guareschi. 9. ed. Petrópolis, RJ: Vozes, 2011.

BAUMAN, Z. Modernidade líquida. Rio de Janeiro: Jorge Zahar Editor, 2001. Identidade: entrevista a Benedetto Vecchi. Rio de Janeiro: Jorge Zahar, 2005.

BERNSTEIN, B. A estruturação do discurso pedagógico: classe, códigos e controle. Vozes: Petrópolis, 1996.

BHATIA, V. K. Analysing Genre: language use in professional settings. New York: Longman, 1993.

BINNICK, Robert I.- "'Will and Be going to". Papers from tlle Seventh Regional Meeting Chicago Línguistic Society. Chicago, p. 40-51, 1971. 
BIZATTO, J. I.; BIZATTO, R.M. Adolescente infrator: uma proposta de reintegração social baseada em políticas públicas. 1. ed. São Paulo: Baraúna, 2014.

BRANDÃO, H.H.N. Introdução à análise do discurso. 2. ed. Campinas, SP: Editora da UNICAMP, 2004.

BRASIL. Lei n. 12.594, de 18 de janeiro de 2012. Institui o Sistema Nacional de Atendimento Socioeducativo (Sinase) e dá outras providências. Disponível em: <http://www.planalto.gov.br/ccivil_03/_ato2011-2014/2012/lei/112594.htm>. Acesso em 20 jul. 2016.

BUTT, D; FAHEY, R; FEEZ, S; SPINKS, S. Using functional grammar: an explore's guide. Sydney: Macquarie University, 2001.

CAMPÊLO, S.R.S. Adolescência, pobreza e inclusão digital: práticas discursivas e identidades (re)construídas no espaço virtual. Brasília, 2014. Dissertação (Mestrado em Linguística) - programa de Pós-Graduação em Linguística, Universidade de Brasília, 2014.

CASTELEIRO, J.M. A arte de mandar em português: estudo sintático-estilístico baseado em autores portugueses e brasileiros. 1. ed. Rio de Janeiro: Lexikon, 2014.

CASTELLS, M. O poder da identidade. São Paulo: Paz e Terra, 1999.

CARVALHO, A.C.C. Reintegração dos presos por meio da educação a distância. Brasília: Editora Ser, 2011.

CARVALHO, K.G. Técnica Legislativa. 4. ed. Belo Horizonte: Del Rey, 2007.

CHOULIARAKI, L.; FAIRCLOUGH, N. Discourse in Late Modernity. Rethinking Critical Discourse Analysis. Gra-Bretanha: Edinburgh University Press, 1999.

CIAMPA, A. C. A estória do Severino e a história da Severina. São Paulo: Editora Brasiliense, 1987.

COHEN,L; MANION,L. Research methods in education. London: Croom Help, 1983.

CORÔA, M. L. M. S.O Tempo nos Verbos do Português: Uma Introdução à sua Interpretação Semântica. Brasília, Thesaurus, 1985.

CORREIA, J.D.M. A disciplina no Colégio Militar: uma reflexão. O Saber: revista técnicocientífica. Brasília: Colégio Militar de Brasília, 2014.

COSTA, A.; COSTA, N. Limites e disciplina na relação pais e filhos. Belém: UFPA, 2002.

CRESWELL, John W. Projeto de pesquisa: métodos qualitativo, quantitativo e misto. Tradução: Magda Lopes; consultoria, supervisão técnica: Dirceu da Silva. 3. ed. Porto Alegre: Artmed, 2010.

DENZIN, N.K.; LINCOLN, Y.S. O planejamento da pesquisa qualitativa: teorias e abordagens. Tradução: Sandra Regina Netz. 2. ed. Porto Alegre: ARTMED, 2006. 
DIAS, J.F. Analistas de Discurso e sua prática teórica e metodológica. Cadernos de Linguagem e Sociedade. Brasília, v. 12 (2), 2011.

DREYFUS, J.; RABINOW, P. Michel Foucault: Beyound Structuralism and Hermeneutics. Brighton: Harvest, 1982.

EGGINS, S. An Introduction to Systemic Functional Linguistics. London: Pinter Publishers, 1994.

EGGINS, S.; MARTIN, J. Genres and registers of discourse. In: van DIJK, T. Discourse as Structure and Process. v. I. London, Thousand Oaks, New Delhi: Sage, 1997. p. 230-256.

. Genres and registers of discourse. In: VAN DIJK, T.A. (Ed.). Discourse: a multidisciplinary introduction. London: Sage, 1996.

El context como género: una perspectiva linguística funcional. Revista Signos, v. 36, $\mathrm{n}^{\circ}$ 54, p. 185-205, 2003.

EXÉRCITO BRASILEIRO - MINISTÉRIO DA DEFESA - Disponível em: <http//:www.eb.mil.br>. Acesso em: 30 jun. 2016.

FAIRCLOUGH, N. Critical Discourse Analysis: The Critical Study of Language.2nd ed. United Kingdom: Longman, 2010.

. Language and Globalization. London: Routledge, 2006.

2003.

Analysing discourse. Routledge: Taylor \& Francis Group. London and New York,

Discurso e Mudança Social. Tradução de Izabel Magalhães. Editora: Universidade de Brasília, 2001. (Discourse and social change, 1992)

Language and power. London: Longman, 1989.

FAIRCLOUGH, N.; WODAK, R. Critical Discourse Analysis. In VAN DIJK, Teun A. (Ed). Discourse and social interaction. London: Sage, 1997.

FLICK, U. Qualidade na pesquisa qualitativa. Tradução: Roberto Cataldo Costa. Porto Alegre: Artmed, 2009. (Coleção pesquisa Qualitativa)

. Entrevista episódica. In: BAUER M.W e GASKELL G. (org). Pesquisa qualitativa com texto: imagem e som: um manual prático. Tradução: Pedrinho A. Guareschi. 9. ed. Petrópolis, RJ: Vozes, 2011.

FOUCAULT, M. Microfísica do poder. Rio de Janeiro: Edições Graal, 1979.

Power/Knowledge. Org. C. Gordon. Nova York: Harvester Wheatsheaf, 1980.

As palavras e as coisas: uma Arqueologia das Ciências Humanas. 8. ed. São Paulo, Martins Fontes, 1990.

. História da Sexualidade I: a vontade de saber. Rio de Janeiro: Graal, 1985. 
What is enlightenment?. In: RABINOW, P. (Ed.) Michel Foucault: Essential Works. Harmondsworth: Penguin, v.1 (Ethics), p. 303-319, 1994.

O sujeito e o poder. In: RABINOW, P.; DREYFUSS, H. Michel Foucault: uma trajetória filosófica. Rio de Janeiro: Forense Universitária, 1995.

. A Ordem do Discurso. São Paulo: Loyola, 1996.

Estratégia, poder-saber. Ditos \& Escritos IV. Trad.: Vera Lúcia Avellar Ribeiro. Rio de Janeiro: Forense Universitária, 2003.

Vozes, 2004.

Vigiar e punir: nascimento da prisão. Tradução de Raquel Ramalhete. Petrópolis:

FREIRE, P. Pedagogia da Indignação: cartas pedagógicas e outros escritos. São Paulo: UNESP, 2000.

Terra, 2001.

Pedagogia da Autonomia - Saberes necessários à prática educativa. São Paulo: Paz e

FUZER, C.; CABRAL, S.R.S. Introdução à Gramática Sistêmico-Funcional em Língua Portuguesa. Campinas, SP: Mercado de Letras, 2014.

FUZER, C.; TICKS,L.; CABRAL, S.R.S. Análise Sistêmico-Funcional como suporte para leitura de textos: o caso da cerveja Devassa. RBLA, Belo Horizonte, v.12, nº 4, p.883-909, 2012.

GARAPON, A. O juiz e a democracia: o guardião das promessas. Trad. Maria Luíza de Carvalho, Rio de Janeiro: Revan, 1999.

GARLAND, D. A cultura do controle: crime e ordem social na sociedade contemporânea. Rio de Janeiro: Revan, 2008.

GASKELL, G. Entrevistas individuais e grupais. In: BAUER M.W e GASKELL G. (org). Pesquisa qualitativa com texto: imagem e som: um manual prático. Tradução: Pedrinho A. Guareschi. 9. ed. Petrópolis, RJ: Vozes, 2011.

GOFFMAN, E. Estigma: notas sobre a Manipulação da Identidade deteriorada. Trad. Márcia Bandeira de Mello Leite Nunes. Rio de Janeiro: LTC, 1975.

GOUVEIA, C.A.M. Texto e gramática: uma introdução à Linguística Sistêmico-Funcional. Matraga 24. v.16 jan./jun. 2009. Rio de Janeiro: UERJ, p. 13-47, 2009.

Regulamentos, disciplina e hierarquia de relações na instituição militar. In: PEDRO, E.R. (org). Análise Crítica do Discurso: uma perspectiva sociopolítica e funcional. Editorial Caminho: Lisboa, 1997.

GHIO, E.; FERNÁNDEZ,M.D. Linguística Sistêmico Funcional. Aplicaciones a la lengua española. Santa Fe: Universidad Nacional del Litoral, Waldhuter Editores, 2008. 
GROULX, L.H. Contribuição da pesquisa qualitativa à pesquisa social. In: POUPART, J. at all. A pesquisa qualitativa: enfoques epistemológicos e metodológicos. Tradução: Ana Cristina Nasser. 3. ed. Petrópolis, RJ: Vozes, 2012.

GUILLOT, G. O resgate da autoridade em educação. Tradução: Patrícia Chittoni Ramos Reuillard. Porto Alegre: Artmed, 2008.

GUIMARÃES, E. Texto, discurso e ensino. São Paulo: Contexto, 2009.

. Domínio semântico de determinação. GUIMARÃES, E.; MOLLICA, M.C. (Orgs.) A palavra: forma e sentido. Campinas: Pontes Editores, RG Editores, 2007.

http://g1.globo.com/fantastico/noticia/2013/08/imagens-mostram-funcionarios-da-fundacaocasa-espacando-menores.html. Acesso em 11 dez. 2013.

http://www.unicef.org/brazil/pt/activities.html. Acesso em: 30 jul. 2016.

HALL, S. A identidade cultural na pós-modernidade. Tradução Tomaz Tadeu da Silva, Guaracira Lopes Louro. 10. ed. Rio de Janeiro: DP\&A, 2005.

. Quem precisa da identidade? In: SILVA, Tomaz Tadeu da (Org.). Identidade e diferença: a perspectiva dos estudos culturais. Tradução de Tomaz Tadeu da Silva. Petrópolis: Vozes, 2012.

HALLIDAY, M.A.K. On Language and Linguistics. v.3 in the Collected Works of M.A.K.Halliday. Jonathan Webster Continuum (ed). New York: Equinox, 2003.

An Introduction to Functional Grammar. London: Edward Arnold, 1994.

Part A. In: HALLIDAY, M.A.K.; HASAN, R. Language, context and text: aspects of language in social-semiotic perspective. Oxford: Oxford University Press, 1989.

Language as Social Semiotic: the Social Interpretation of Language and Meaning. London \& Baltimore: Edward Arnold \& University Park Press, 1986. - 1978.

.Explorations in the Functions of Language. London: Edward Arnold, 1973.

HALLIDAY, M.A.K.; HASAN, R. Cohesion in English. London: Longman, 1976.

Language, context and text: aspects of language in social-semiotic perspective. Hong Kong: Oxford Press, 1985.

HALLIDAY, M.A.K.; MARTIN, J. Writing science: literacy and discursive power. London and Pittsburgh. University of Pittsburgh Press, 1993.

HALLIDAY, M.A.K.; MATTHIESSEN, C.M.I.M. An Introduction to functional grammar. 3rd. ed. Londres: Arnold, 2004.

Halliday's Introduction to Functional Grammar. 4th ed. London and New York: Routledge, 2014.

HASAN, R. Text in the Systemic-Functional Model. In: DRESSLER, Wolfgang. (Ed.) Current Trends in Textlinguistics. Berlin: Walter de Gruyter, pp.228-246, 1977. 
The Nursery Tale as a Genre. Nottingham Linguistic Circular (Special Issue on Systemic Linguistics). v.13, p.71-102, 1984.

HASAN, R.; G. PERRERT. Learning to function with the other tongue. ODLIN, T. (ed), Perspectives on pedagogic grammars. New York: Cambridge University Press, 1994.

ISHIDA, V.K. Estatuto da criança e do adolescente: doutrina e jurisprudência. 14. ed. São Paulo: Atlas, 2013.

JUNKER, H. B. A importância do trabalho de campo: uma introdução às ciências sociais. Rio de Janeiro: Lidador Ltda, 1971.

KOCH, I.G.V. Linguagem e cognição: a construção e reconstrução de objetos-de-discurso. Veredas - revista de estudos linguísticos. v. 6, $\mathrm{n}^{\mathbf{0}}$ 1, jan./jun. 2002. Juiz de Fora: Editora UFIF, 2003. p. 29-41.

Argumentação e linguagem. 13. ed. São Paulo: Cortez, 2011.

KOCH, I.G.V.; Elias, V.M. Ler e compreender: os sentidos do texto. 2. ed. São Paulo: Contexto, 2007.

KOCH, I.G.V; BENTES, A.C.; CAVALCANTE, M.M. Intertextualidade: diálogos possíveis. 3. ed. São Paulo: Cortez, 2012.

KRESS, G.R. Linguistics processes in sociocultural practice. Oxford: Oxford University Press, 1989.

LIMA, G. Guia para elaboração de Regimento Interno de que trata a Portaria 350/2014. Disponível em: <gabrieldelima.jusbrasil.com.br> . Acesso em: 15 abr. 2015.

LINS, M.N. Medalhas no peito, diploma na mão. Revista Época. Ed. 749. São Paulo: Globo, 2012.

LOPES, A. C. Narrativas das adolescentes em conflito com a lei. Brasília, 2003. Dissertação (Mestrado em Linguística) - programa de Pós-Graduação em Linguística, Universidade de Brasília.

MARCUSCHI, L. A. O Papel da Atividade Discursiva no Exercício do Controle Social. Cadernos de Linguagem e Sociedade, Brasília, v.7, 2005.

Produção textual, análise de gêneros e compreensão. São Paulo: Parábola, 2008.

MARTIN, J. R. Beyond Exchange: Appraisal system in English. In: HUNSTON, S.; THOMPSON, G. Evaluation in text: authorial stance and the construction of discourse. Oxford: Oxford University Press, 2000.

MARTIN, J. R.; MATTHIESSEN, C.M.I.M.; PAINTER, C. Working with functional grammar. London: Arnold, 1997.

Deploying functional gramar. Beijing: The Commercial Press, 2010. 
MARTIN, J. R.; ROSE, D. Working with discourse: meaning beyond the clause. Londres; Nova York: Continuum, 2007.

MARTIN, J. R.; WHITE, P. The language of evaluation: Appraisal in English. London: Palgrave Macmillan, 2005.

MARTINS, E.C. A. A criança do estatuto e o estatuto de criança: um estudo discursivo sobre a representação infanto-juvenil na justiça manauara. Brasília, 2012. Dissertação (Mestrado em Linguística) - programa de Pós-Graduação em Linguística, Universidade de Brasília.

MATTHIESSEN, C.M.I.M; HALLIDAY, M. A. K. Systemic functional grammar: a first step into the theory. Beijing: Higher Education Press, 2009.

MEURER, J.L. Ampliando a noção de contexto na Linguística Sistêmico-Funcional e na Análise Crítica do Discurso. Linguagem em (Dis)curso - LemD. Tubarão- SC, v.4, p. 133157, 2004.

MEURER, J. L. Esboço de um modelo de produção de textos. In: MEURER, J.L.; MOTTAROTH, D (Eds.). Parâmetros de textualização. Santa Maria: Editora da UFSM, 1997.

MILROY, L. Observing \& analysing natural language. Oxford: Blackwell, 1987. (Série language. Society: 12)

MIRANDA, H.S. Meninos, Moleques, Menores... Faces da Infância no Recife 1927 - 1937. 2008. Dissertação (Mestrado em História Social da Cultura Regional). Universidade Federal Rural de Pernambuco - UFRPE, Recife - PE, 2008.

MOITA LOPES, L.P. A transdisciplinaridade é possível em Linguística Aplicada? In: SIGNORINI, I.; CAVALCANTI, M.C. (Org.) Linguística aplicada e transdisciplinaridade. Campinas, SP: Mercado de Letras, 1999.

MONDADA, L. Verbalisation de l'espace et fabrication du savoi: approche linguistique de la construction des objets du discours. Lausanne: Université de Lausanne, 1994.

MONTECINO, L; VIDAL, M. Representación del consumo de drogas em historias de vida de personas em situación de calle em Santiago de Chile. ALED, 2011 (1), p. 93-109.

MOREIRA, K.C. A. Discurso de adolescentes em situação de rua: da ruptura à exclusão. Brasília. Dissertação (Mestrado em Linguística) - programa de Pós-Graduação em Linguística, Universidade de Brasília, 2007.

MOREIRA, K.C. A. Representações linguístico-discursivas pertinentes a crianças $e$ adolescentes em situação de risco: perspectivas para a inclusão educacional. Brasília: Universidade de Brasília, 2013.

MOREIRA, M. A. Práticas discursivas e sociais na relação família-escola-comunidade: da realidade da adolescência ao discurso legal no Brasil. 2015. Tese (Doutorado em Linguística). Programa de Pós-Graduação em Linguística. Brasília: Universidade de Brasília, 2015.

MOTTA-ROTH, D.; HEBERLE, V. O conceito de "estrutura potencial de gênero" de Ruqayia Hasan. In: MEURER, José Luiz; BONINI, Adair; MOTTAROTH, Désirée. Gêneros: teorias, métodos, debates. São Paulo: Parábola, 2005. 
MUNIZ DA SILVA, E. C. Ciclo de Aprendizagem baseada em Gêneros. Linguagem Estudos e pesquisas. Vol. 19, no. 02, p. 19-37, jul./dez., 2015.

NETO, F.B. Adolescente: o desafio de entender e conviver. Florianópolis: Insular, 2011.

NEVES, M.H.M. Ensino de língua e vivência de linguagem: temas em confronto. São Paulo: Contexto, 2010.

A gramática: história, teoria e análise, ensino. São Paulo: Editora UNESP, 2002.

OLIVEIRA, F. C. M. Sistema de cotas raciais à brasileira: uma análise linguísticodiscursiva. Tese (Doutorado). Universidade de Brasília, 2016.

OLIVEIRA, M.K. Vygotski: aprendizado e desenvolvimento - um processo sócio-histórico. São Paulo: Scipione, 2006.

PACHECO, M.C.N. Identidade e intertextualidade em narrativas de Docentes e em textos de Leis Federais Brasileiras, de 1960 a 2000. 195 f. Tese (Doutorado)-Departamento de Linguística, Português e Línguas Clássicas. Universidade de Brasília, 2006.

PARDO, M.L. Teoría de la investigación linguística: método sincrônico-diacrónico de análisis de textos. $1^{\mathrm{a}}$ ed. Buenos Aires: Tersites, 2011.

PASSOLD, C. Função Social do Estado Contemporâneo. Florianópolis: Ladesc, 1984.

POLANYI, L. Telling the american story: a structural and cultural analysis of conversation storytelling. Nova Jersey: Ablex, 1985.

PROGRAMA PARA AVANÇO DAS APRENDIZAGENS ESCOLARES - PAAE para o estudante do Ensino Fundamental da Rede Pública de Ensino do Distrito Federal em defasagem idade-ano. Brasília, abril de 2016.

RAJAGOPALAN, K. Por uma linguística crítica: linguagem, identidade e a questão ética. São Paulo: Parábola Editorial, 2003.

RAMALHO, V. Macrofunção interpessoal da linguagem e construção de identidades em discursos sobre conflitos internacionais. Congresso Internacional de Linguística SistêmicoFuncional. São Paulo, 2006. Livro da 33º ISFC. São Paulo: ISFC, pp.315-329, 2006.

RAMALHO, V.; RESENDE, V. M. Análise de Discurso (para a) Crítica: o texto como material de pesquisa. Campinas, SP: Pontes Editores, 2011.

RESENDE, V.M. Análise do Discurso Crítica e Realismo Crítico: Implicações Interdisciplinares. Campinas, SP: Pontes Editores, 2009.

Análise de Discurso Crítica e Etnografia: o Movimento Nacional de Meninos e Meninas de Rua, sua crise e o protagonismo juvenil. 332f. Tese (Doutorado)-Departamento de Linguística, Português e Línguas Clássicas. Universidade de Brasília, 2008.

RESENDE, V. M; RAMALHO, V. Análise de Discurso Crítica. São Paulo: Contexto, 2006.

REVEL, J. Michel Foucault: conceitos essenciais. Tradução: Maria do Rosário Gregolin, Nilton Milanez, Carlos Piovesani. São Carlos: Claraluz, 2005. 
RIZZINI, Irene. $O$ Século perdido: raízes históricas das políticas públicas para infância no Brasil. Rio de Janeiro: Petrobrás - BR: Ministério da Cultura: USU Ed. Universitária, 1997.

RIZZINI, I; RIZZINI, I. A institucionalização de crianças no Brasil: Percurso Histórico e Desafios do Presente. Rio de Janeiro: Ed. PUC-Rio; São Paulo: Loyola, 2004.

RÓNAI, P. Com a colaboração de Aurélio Buarque de Holanda. Não perca seu Latim. Rio de Janeiro: Nova Fronteira, 1984.

SANT'ANNA, A.S. Disciplina: o caminho da vitória. Curitiba, PR: Cócegas Editora, 2010.

SARDINHA, T.B. Pesquisa em linguística de Corpus com WordSith Tools. Campinas, SP: Mercados das Letras, 2009.

SATO, D.T.B.; JÚNIOR, J.R.L.B. Contribuições da análise de discurso crítica no Brasil: uma homenagem à Izabel Magalhães. Campinas, SP: Pontes Editores, 2013.

SEARLE, J. The Classification of Illocutionary Acts, Language and Society, 5, p.1-24, 1976.

SÊDA, Edson. Infância e sociedade: terceira via. São Paulo: ADÊS, 1998.

SILVA, A. A expressão da Futuridade na língua falada. Curso de Linguística do Instituto de Estudos da Linguagem da Universidade Estadual de Campinas. Tese de Doutorado. Campinas, SP: UNICAMP, 1997.

SILVA, D.E.G. A política da desigualdade no Brasil: adolescentes em situação de rua. In: LARA, G.P.; LIMBERTI, R.P. (Orgs.). Discurso e (des)igualdade social. São Paulo: Contexto, pp. $79-93,2015$.

Discurso do ecologismo e ecologia humana: caminhos entre etnogragia crítica e ecolinguística. In: Hildo Couto (Org). Cadernos de Linguagem e Sociedade, v. 14 (1), pp. 6588. Brasília: Thesaurus/NELIS/CEAM/UnB; Programa de Pós-Graduação em Linguística, $2013 \mathrm{a}$.

."A gente" no lugar de um elemento pronominal perdido. Anais do IV - SIMELP Simpósio Mundial de Língua Portuguesa, Goiânia, 2013b. pp. 355-363. Disponível em: <http://www.simelp.letras.ufg.br/anais/simposio_08.pdf>. Acesso em 05 jul. 2016.

A gramática da pobreza em práticas discursivas de atores sociais: uma perspectiva crítica. In J. Plaza e B. F. Fabrício (Orgs.). Exclusão social e microrresistências: a centralidade das práticas discursivo-identitárias, pp. 87-11. Goiânia: Cânone Editora, 2013c.

"Leituras rumo às margens de sentido(s): viagem do texto ao discurso". In: ZATTAR, N.; DI RENZO, A.M. (Orgs.). Estudos da linguagem: língua, sujeito e história. Campinas, SP: Pontes Editores, 2012.

- Estudos críticos do discurso no contexto brasileiro: por uma rede de transdisciplinaridade. EUTOMIA Revista de Literatura e Linguística, Recife, n. UFPE, pp. 224-243, 2012.

Representações em práticas discursivas midiáticas: alimento da pobreza "abstrata". Congreso Internacional de Discurso y Medios, Buenos Aires. El rol del discurso en los 
medios masivos de comunicación. Actas del I Congreso Internacional de Discurso y Medios. Buenos Aires: UBA, v.1, 2011.

Representações discursivas da pobreza e discriminação na mídia. In: SILVA, Denize Elena G.da, LEAL, Maria Chritina D. \& PACHECO, Marta C. de N (orgs). Discurso em questão: representação. Gênero, identidade, discriminação. Goiânia: Cânone editorial, 2009.

A pobreza no contexto brasileiro: da exclusão econômica social à ruptura familiar. Discurso \& Sociedad, 2(2), p. 265-296, 2008.

. Identidades enfraquecidas versus cidadania cultural. In: Joachin Sèbastien (Org.). Diversidade cultural, linguagens e identidades. Recife: Elógica, vol. 1, 2007a, p. 51-68.

- Análise de discurso crítica e as bases funcionais da linguagem. $33^{\circ}$ ISFC Congresso Internacional de Linguística Sistêmico-Funcional. São Paulo, 2006. Livro da $33^{\circ}$ ISFC. São Paulo: ISFC, pp. 932-949, 2006.

Nas instâncias do discurso: uma permeabilidade de fronteiras. Brasília: Editora Universidade de Brasília: Oficina Editorial do Instituto de Letras, 2005.

Gramática e contexto na perspectiva funcional do discurso. In: D.E.G. da Silva; G.M.P.Lara; M.A.Menegazzo (Orgs.). Estudos de linguagem: interrelações e perspectivas. Campo Grande (MS): Ed. UFMS, pp 55 - 70, $2003 a$.

A ética na pesquisa: reflexões sobre metodologia na coleta de dados. In: VIEIRA, J.A.; SILVA, D.E.G.(Orgs). Práticas de Análise do Discurso. Brasília: Plano Editora: Oficina Editorial do Instituto de Letras, UnB, 2003b.

A oralidade no Discurso narrativo Escrito de adolescentes. 171f. Dissertação (Mestrado)-Departamento de linguística, línguas Clássicas e Vernácula. Universidade de Brasília, 1991.

SILVA, E. C. M. Do discurso à gramática: um enfoque crítico e funcional de gêneros. $L \& S$ : Cadernos de Linguagem e Sociedade/Papers on language and society. Org: Silva, D.E.G. v.11. n². Pp. 62-77. Brasília: Thesaurus, 2010.

SILVA, F.C.O. A construção social de identidades étnico-raciais: uma análise discursiva do racismo no Brasil. 2009. 267f. Tese (Doutorado em Linguística)-Programa de Pós-Graduação em Linguística, Universidade de Brasília, Brasília, DF, 2009.

SILVA, T. Identidade e diferença: a perspectiva dos estudos culturais. Petrópolis: Vozes, 2009.

SILVEIRA, M.I.M. O Burocratês: Análise à luz de uma Gramática Retórica. Revista da ABRALIN, v.7, n 1 , p. 215-258, jan./jun. 2008.

SOUZA, C.A.L. Discursividades em um plano de desenvolvimento agrário: facetas de práticas sociais (re)produzidas. Tese de Doutorado (Inédita) - Programa de Pós-Graduação em Linguística, Universidade de Brasília, 2015. 
STAINBACK, S. Inclusão: um guia para educadores. Tradução: Magda França Lopes. Porto Alegre: Artmed, 1999.

STAKE, E.R. Pesquisa qualitativa: estudando como as coisas funcionam. Tradução: Karla Reis. Porto Alegre, 2011.

STUBBS, M. Discourse analysis: The Sociolinguistic analysis of natural language. Oxford: Blackwell, 1983.

TAJFEL, H. Differentiation between social groups. New York: Academic Press, 1978. Human groups and social categories. New York: Cambridge University Press, 1981.

THOMPSON, G. Introducing functional grammar. London: Hodder Education, 2004.

THOMPSON, G.; COLlinS, H. Interview with M. A. K. Halliday. Cardiff, July, 1998. Delta. São Paulo: EDUC, v. 17, nº 1, 131-153, 2001.

THOMPSON, John B. Ideologia e cultura moderna: teoria social crítica na era dos meios de comunicação de massa. Tradução do Grupo de Estudos e Ideologia, comunicação e representações sociais da pós-graduação do Instituto de Psicologia da PUCRS. Petrópolis: Vozes, 2011.

TILIO, R. Revisitando a Análise Crítica do Discurso: um instrumental teórico-metodológico. e-scrita. Revista do Curso de Letras da UNIABEU. Nilópolis, v.1, n², maio-ago, 2010.

UCHIMURA, K.Y.; BOSI, M.L.M. A polissemia da qualidade na avaliação de programas e serviços de saúde: resgatando a subjetividade. In: BOSI, M.L.M.; MERCDO-MARTÍNEZ, F. (Org.) Pesquisa qualitativa de serviços de saúde. $2^{\mathrm{a}}$ ed. Petrópolis, RJ: Vozes, 2007.

UNESCO: Marco estratégico para UNESCO no Brasil, 2006. unesdoc.unesco.org/images/0014/001475/147544por.pdf. Acesso em 30/07/2016.

VAN DIJK, T.A. La noticia como discurso. Comprensión, estructura y Producción de La información. Barcelona: Paidós Comunicación, 1990.

VIAN JR., O. Sobre o conceito de gêneros do discurso: diálogos entre Bakhtin e a linguística sistêmico funcional. In: BRAIT, BETH(Org.). Estudos Enunciativos no Brasil: Histórias e Perspectivas. Campinas, SP: Pontes: São Paulo: Fapesp, 2001.

.O sistema de avaliatividade e os recursos para gradação em Língua Portuguesa: questões terminológicas e de instanciação. DELTA, vol. 25, n 1, pp. 99-129, 2009.

WODAK, R. Do que trata a ACD: um resumo de sua história, conceitos importantes e seus desenvolvimentos. Revista Linguagem em (Dis)curso, v. 4, $\mathrm{n}^{\circ}$ especial, 2004. Disponível em: <http://www3.unisul/paginas/ensino/pos/linguagem/revista.htm>. Acesso em: 12 maio 2015.

WOODWARD, K. Identidade e diferença: uma introdução teórica e conceitual. In: SILVA, T. Identidade e diferença: a perspectiva dos estudos culturais. Petrópolis: Vozes, 2009. 